\begin{abstract}
UNIVERSIDADE DE SÃO PAULO
FACULDADE DE FILOSOFIA, LETRAS E CIÊNCIAS HUMANAS DEPARTAMENTO DE GEOGRAFIA

PROGRAMA DE PÓS-GRADUAÇÃO EM GEOGRAFIA HUMANA
\end{abstract}

MÁRCIO ROCHA DE SOUZA

A EDUCAÇÃO DE JOVENS E ADULTOS: UM ESTUDO A PARTIR DAS QUEDAS NAS MATRÍCULAS INICIAIS NO PERÍODO DE 2000 A 2012.

VERSÃO CORRIGIDA

SÃo PAULO

2013 


\author{
UNIVERSIDADE DE SÃO PAULO \\ FACULDADE DE FILOSOFIA, LETRAS E CIÊNCIAS HUMANAS \\ DEPARTAMENTO DE GEOGRAFIA \\ PROGRAMA DE PÓS-GRADUAÇÃO EM GEOGRAFIA HUMANA
}

\author{
MÁRCIO ROCHA DE SOUZA
}

\title{
A EDUCAÇÃO DE JOVENS E ADULTOS: UM ESTUDO A PARTIR DAS QUEDAS NAS MATRÍCULAS INICIAIS NO PERÍODO DE 2000 A 2012.
}

Dissertação apresentada ao Departamento de Geografia da Faculdade de Filosofia, Letras e Ciências Humanas, da Universidade de São Paulo, para obtenção do título de Mestre em Geografia Humana.

Orientadora: Professora Doutora Nídia Nacib Pontuschka.

VERSÃO CORRIGIDA

$$
\text { SÃO PAULO }
$$




\section{Folha de Aprovação}

SOUZA, Márcio Rocha de. A educação de jovens e adultos: um estudo a partir das quedas nas matrículas iniciais no período de 2000 a 2012. Dissertação apresentada ao Departamento de Geografia da Faculdade de Filosofia, Letras e Ciências Humanas, da Universidade de São Paulo, para obtenção do título de Mestre em Geografia Humana.

Aprovado em: 29/08/2013.

\section{Banca Examinadora}

Profa. Dra.:

Instituição:

Julgamamento:

Assinatura:

Profa. Dra.:

Instituição:

Julgamamento:

Assinatura:

Profa. Dra.:

Instituição:

Julgamamento:

Assinatura: 


\section{AGRADECIMENTOS}

Aos meus pais. Minha mãe, Aparecida, que me apoiou nas horas mais difíceis e me abrigou para que eu pudesse concluir este trabalho. Meu pai, Antônio (in memoriam), sempre me apoiou e realizou sacrifícios, desde o nosso sustento à nossa educação.

À Profa. Dra. Nídia Nacib Pontuschka, pela sua dedicação e profissionalismo. Pelas orientações que foram para além deste trabalho, seguirão para a vida.

Às amigas Édna Bonassi e Vânia do Socorro Fernandes que tanto incentivaram à realização desse sonho.

Às professoras que colaboraram de maneira ímpar ao meu aprendizado na Academia. Das disciplinas cursadas: Jutta Gutberlet, Marta Inez Medeiros Marques e Nídia Nacib Pontuschka. Das orientações na qualificação: Carla Silvia Pimentel e Léa Francesconi.

Aos colegas do Grupo de Estudos Interdisciplinares com a Professora Nídia na FEUSP, que contribuíram de muitas maneiras nessa fase da vida acadêmica e da vida pessoal: Amália Engel, Ari da Silva Fonseca Filho, Bruno Muniz F. Costa, Dulcinéia Boscolo, Edjailson Bezerra da Silva, Édna Bonassi, Gustavo José Prado, Marco Antonio Latorre, Marcos de Oliveira Soares, Robson Novaes da Silva, Rosangela Hilário, Tiago Dionísio da Silva e Vivian Fiori.

Aos professores e gestores das escolas municipais de São Paulo que colaboraram com o desenvolvimento deste trabalho.

Aos colegas e amigos que tanto apoiaram nas horas e decisões mais difíceis da minha vida profissional e pessoal, quando das condições de ingresso, continuidade e conclusão deste trabalho: Alex Ovchnnikov, Ana Bermude, Márcia Ovchnnikov, Marcela Nardi de Pádua, Vânia do Socorro Fernandes e Vera Lígia F. S. Souza. 
"Não devemos, de modo algum, recear abordar um problema qualquer que estejamos em condições de elucidar. Não devemos, desencorajados, deixar cair os braços para murmurar resignadamente: agnorabimus (ignoraremos), pois desse modo jamais saberemos o que quer que seja. Este desencorajamento, todavia, caracteriza o pensamento burguês moderno. Em vez de tender, com todas as suas forças, para alargar e aprofundar o nosso saber, ele aplica-se afincadamente a fixar-Ihe os limites e a desacreditar a certidão do conhecimento científico". 


\section{RESUMO}

SOUZA, M. R. A educação de jovens e adultos: um estudo a partir das quedas nas matrículas iniciais no período de 2000 a 2012, 2013. $188 \mathrm{f}$. Dissertação (Mestrado) - Faculdade de Filosofia, Letras e Ciências Humanas, Departamento de Geografia, Universidade de São Paulo, São Paulo, 2013.

A presente dissertação analisa os índices nas quedas das matrículas iniciais nos cursos de Educação de Jovens e Adultos no Brasil entre 2000 a 2012, com ênfase a partir do ano de 2008 após a Reorganização destes cursos na cidade de São Paulo, promovida pela Secretaria Municipal de Educação. Os conceitos que fundamentaram nossas análises foram os do trabalho, educação e das contradições, analisados sob o capital. $\mathrm{Na}$ pesquisa ao ampliar a escala de observação, revelaram-se quedas nas matrículas em âmbito nacional. A partir da constatação nos índices dessas quedas nas matrículas em EJA, tornou-se o foco da pesquisa identificar as condicionantes e as determinantes que impulsionaram tais quedas nas matrículas destes cursos para Jovens e Adultos. Buscamos fundamentar a hipótese central ao problema apresentado sob dois parâmetros. O primeiro na investigação pela abordagem quantitativa, pela frequência dos índices apontados pelos institutos oficiais de recenseamento e estatísticas consultados e analisados sob a metodologia de análise de conteúdos, de acordo com Bardin (1977) e o segundo parâmetro qualitativamente, pela presença com que os dados emergiram no levantamento empírico em campo. O materialismo dialético foi a base epistemológica que norteou o pensamento central nas análises, orientadas em Lefebvre (1969; 2006). Dos resultados, como tendência determinante, emergiu o crescimento na oferta das carteiras de trabalho assinadas, no período de realização desta pesquisa. A pesquisa eleva à discussão sobre o pensamento liberal dominante e seus discursos, dos quais, têm sustentado algumas ações de governos municipais, estaduais ou federal em políticas educacionais para os cursos dessa modalidade de ensino. Tenta desocultar o problema apresentado na pesquisa, desde as suas bases, considerando as complexas relações sociais que se estabelecem nas sociedades atuais.

Palavras-chave: Educação de Jovens e Adultos. Carteira de Trabalho Assinada. Matrículas Iniciais. Escola Municipal. Zona Sul da cidade de São Paulo. 


\section{ABSTRACT}

SOUZA, M. R. The education of youth and adults: a study from the initial enrollment declines in the period 2000-2012, 2013. 188f. Thesis (Master) - Faculdade de Filosofia, Letras e Ciências Humanas, Departamento de Geografia, Universidade de São Paulo, São Paulo, 2013.

This dissertation analyzes the indexes on the falls of initial enrollment in the courses Youth and Adults in Brazil from 2000 to 2012, with emphasis from the year 2008 after the reorganization of these courses in the city of São Paulo, sponsored by the Municipal education. The concepts that underlie our analyzes were the work, education and contradictions, analyzed under the capital. In research to expand the scale of observation, proved declines in enrollments nationwide. From the observation of these indices declines in enrollments in adult education, has become the focus of research to identify conditions and determinants that drove these declines in enrollment in these courses for youngsters and adults. We seek to support the central hypothesis to the problem in two parameters. The first research on the quantitative approach, the frequency of the indices mentioned by official institutes census and statistics consulted and analyzed under the methodology of content analysis, according to Bardin (1977) and the second parameter qualitatively by the presence in the data emerged the empirical survey in the field. Dialectical materialism was the epistemological basis that guided the central thought in the analysis, oriented Lefebvre $(1969,2006)$. Results as determining tendency, emerged the growth in supply of work papers signed, from this research. The research raises the discussion of liberal thought and its dominant discourses, which have sustained some actions of municipal, state or federal education policy for the courses of this type of education. Tries to uncover the problem presented in the research, since its foundation, considering the complex social relations that are established in current societies.

Keywords: Education for Youth and Adults. Working Papers Signed. Initial enrollment. Municipal School. South Zone of the city of São Paulo. 


\section{Lista de Figuras}

Figura 1 Gráfico 1: Resultados Finais do Censo Escolar do Município de São Paulo...................................................... 32

Figura 2 Gráfico 2: Evolução das Matrículas em EJA ANO/ANO - Período de $2001-2012$, ACRE.......................................... 74

Figura 3 Gráfico 3: Evolução das Matrículas em EJA ANO/ANO - Período de 2001 - 2012, SÃO PAULO ..................................74

Figura 4 Gráfico 4: Matrículas Iniciais EJA-2000-2012, SÃO PAULO....76

Figura 5 Gráfico 5: Evolução das Carteiras de Trabalho Assinadas SÃO PAULO.................................................. 76

Figura 6 Gráfico 6: Matrículas Iniciais EJA - 2000-201, ACRE ..........76

Figura 7 Gráfico 7: Evolução das Carteiras de Trabalho Assinadas

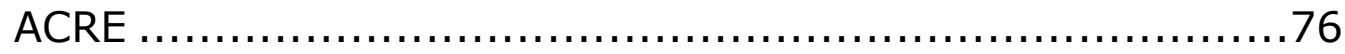

Figura 8 Gráfico 8: Evolução nos Rendimentos de Trabalho- Grandes Regiões - Período 2009 para 2011

Figura 9 Gráfico 9: Evolução do Contingente de Ocupados - Por Setor

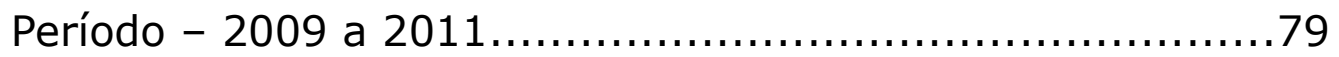

Figura 10 Gráfico 10: Proporção de jovens ocupados de 16 - 24 anos, por setor de atividade econômica..............................123

Figura 11 Imagem de Satélite 1:Cidade Dutra, $2012 \ldots \ldots \ldots \ldots \ldots \ldots \ldots . \ldots 46$

Figura 12 Imagem de Satélite 2: Cidade Dutra, $2004 \ldots \ldots \ldots \ldots \ldots \ldots . \ldots 47$

Figura 13 Imagem de Satélite 3: Jd. IV Centenário, $2004 \ldots \ldots \ldots \ldots \ldots \ldots 47$

Figura 14 Imagem de Satélite 4: Jd. IV Centenário, $2012 \ldots \ldots \ldots \ldots \ldots . \ldots 4$

Figura 15 Mapa 1: Subprefeituras do Município de São Paulo, em destaque o bairro da Cidade Dutra...........................37 


\section{Lista de Tabelas}

Tabela 1 Resultados Finais do Censo Escolar............................26

Tabela 2 Evolução das matrículas ANO/ANO - 1999 a 2012 ............32

Tabela 3 Matrículas Iniciais EJA - Fundamental I e II - Por estados .33

Tabela 3B Matrículas Iniciais EJA - Fund. I e II - Por estados - Evidencia em números negativos o ano de 2007 marco nas quedas das matrículas iniciais.

Tabela 4 Questionário aplicado aos alunos - Questão B3 - Tabulação dos dados

Tabela 5 Questionário aplicado aos alunos - Questão B4 - Tabulação dos dados.

Tabela 6 Questionário aplicado aos alunos - Questão B5 - Tabulação dos dados. 59

Tabela 7 Questionário aplicado aos alunos - Questão B6 - Tabulação dos dados. 60

Tabela 8 Questionário aplicado aos alunos - Questão B7 - Tabulação dos dados

Tabela 9 Evolução das carteiras assinadas, Série Empregos, Anual 154

Tabela 10 Questionário Geral aplicado aos alunos nas escolas "A", "B" e "C" - "sobre você" - Resultados Tabulados.

Tabela 11 Questionário Geral aplicado aos alunos nas escolas "A", "B" e "C" - "sobre seus estudos" - Resultados Tabulados. 


\section{Lista de Quadros}

Quadro 1 Comparativo de Matrículas na EJA - Por Estados - em níveis

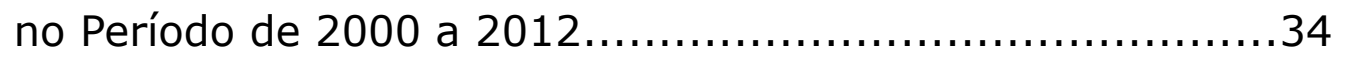

Quadro 2 Comparativo de Matrículas na EJA - Por Estados - em níveis

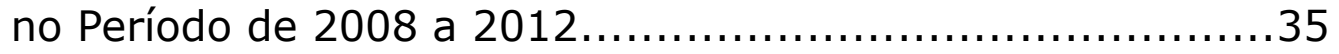

Quadro 3 Subprefeitura Capela do Socorro - População/Demografia

Quadro 4 Composição das Escolas Municipais "A", "B" e "C" ..............50

Quadro 5 Evolução das matrículas Iniciais EJA-Período de 2008 a 2013 nas Escolas Municipais "A", "B" e "C"............................50

Quadro 6 Inventário - Questão B3 - Questionário aplicado aos alunos das Escolas Municipais "A", "B" e "C"...........................55

Quadro 7 Inventário - Questão B4 - Questionário aplicado aos alunos das Escolas Municipais "A", "B" e "C"............................5

Quadro 8 Inventário - Questão B5 - Questionário aplicado aos alunos das Escolas Municipais "A", "B" e "C"............................60

Quadro 9 Inventário - Questão B6-Questionário aplicado aos alunos das Escolas Municipais "A", "B" e "C" 61

Quadro 10 Inventário - Questão B7 - Questionário aplicado aos alunos das Escolas Municipais "A", "B" e "C"...........................63

Quadro 11 Inventário das Categorias Extraídas na Análise das Questões B3 a B7. 65

Quadro 12 Ilustrativo das Aulas do Eixo Variável e do Eixo Central Reorganização da EJA do Município de São Paulo............... 89

Quadro 13 Base de cálculos dos índices de evolução nas matrículas iniciais na EJA - por estados.................................148

Quadro 14 Quadro comparativo relacional - entre os estados e suas

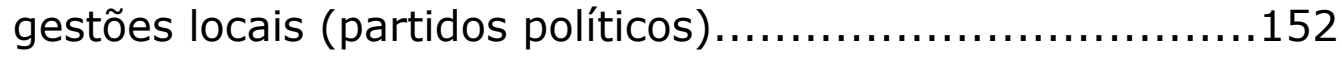

Quadro 15 Evolução no uso da Análise de Conteúdos em estudos.... .153 


\section{Lista das Siglas}

AGB Associação dos Geógrafos Brasileiros

ANPUH Associação Nacional de História

$\mathrm{CCH} \quad$ Complemento de Carga Horária

CEI Centro de Educação Infantil

CEU Centro de Educacional Unificado

CIEJA Centro Integrado de Educação de Jovens e Adultos

CME Conselho Municipal de Educação

CNE Conselho Nacional de Educação

CONFINTEA Conferência Internacional de Educação de Adultos

DIEESE Departamento Intersindical de Estatística e Estudos Socioeconômicos

D.O.M Diário Oficial do Município

DOT-P Diretoria de Orientação Técnica e Pedagógica

DRE Diretoria Regional de Educação

DRE-CS Diretoria Regional de Educação de Capela do Socorro

EJA Educação para Jovens e Adultos

EM Escola Municipal

EMEF Escola Municipal de Educação Fundamental

FIPE Fundação Instituto de Pesquisas Econômicas

FUNDEB $\quad$ Fundo de Desenvolvimento da Educação Básica

FUNDEF Fundo de Manutenção e Desenvolvimento do Ensino Fundamental e de Valorização do Magistério 
IBGE

INEP

JB

JBD

JEIF

LDB

MEC

P.M.S.P

PNLD

PROJOVEM

S.M.E

SECAD

SEE-SP

SENAC

SENAI

SESC

SESI

SINPEEM

UNESCO
Instituto Brasileiro de Geografia Estatística

Instituto Nacional de Estudos e Pesquisas Educacionais

Jornada Básica

Jornada Básica Docente

Jornada Especial Integral de Formação

Lei de Diretrizes e Bases da Educação Nacional

Ministério da Educação e Cultura

Prefeitura Municipal de São Paulo

Programa Nacional do Livro Didático

Programa Nacional de Inclusão de Jovens

Secretaria Municipal de Educação

Secretaria de Educação Continuada, Alfabetização e Diversidade

Secretaria da Educação do Estado de São Paulo

Serviço Nacional de Aprendizagem Comercial

Serviço Nacional de Aprendizagem Industrial

Serviço Social do Comércio

Serviço Social da Indústria

Sindicato dos Profissionais em Educação no Ensino Municipal de São Paulo.

Organização das Nações Unidas para a Educação, Ciência e Cultura 


\section{Sumário}

1. INTRODUÇÃO

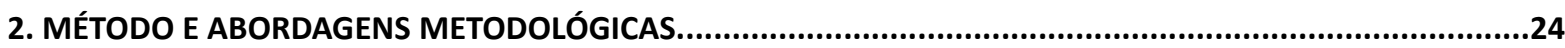

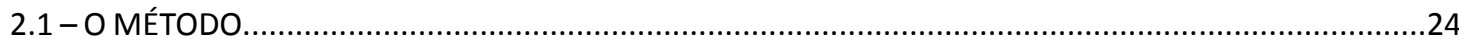

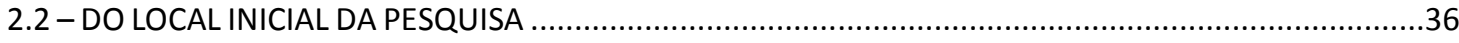

2.3 - AS TRANSFORMAÇõES URBANAS E OS REFLEXOS NA VIDA DAS ESCOLAS .......................................................45

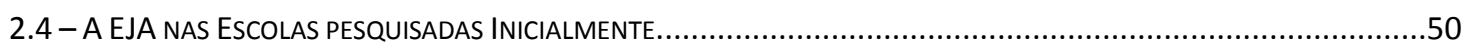

2.5 - A DESCOBERTA NA QUEDA DAS MATRÍCULAS INICIAIS DA EJA EM ÂMBITO NACIONAL .....................................73

3. O ENSINO DA EJA PARA ALÉM DO MUNICÍPIO DE SÃO PAULO …...........................................................81

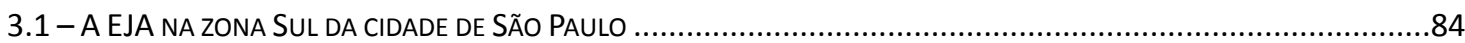

4. A EJA NO CONTEXTO CAPITALISTA BRASILEIRO: EDUCAÇÃO E TRABALHO E SUAS CONTRADIÇÕES .............98

4.1 - O TRABALHO NAS RELAÇÕES DE PRODUÇÃO CAPITALISTA .....................................................................104

4.2 - A EdUCAÇÃO PARA JOVENS E AdULTOS NO CONTEXTO DO CAPITAL .........................................................109

4.3 - A EdUCAÇÃO PARA JOVENS E AdULTOS E O CAMINHO ÀS TRANSFORMAÇÕES NO CAPITALISMO CONTEMPORÂNEO DO

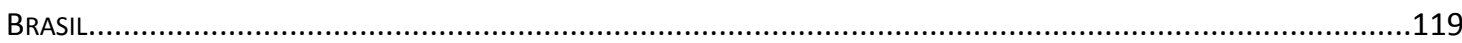

5. CONSIDERAÇÕES FINAIS....................................................................................................................132

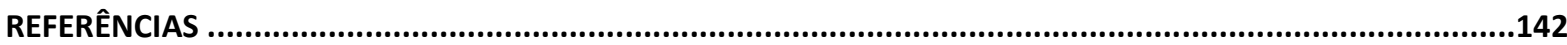

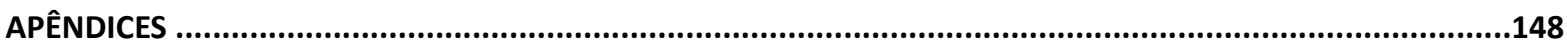

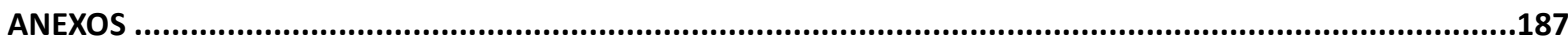




\section{INTRODUÇÃO}

Esta investigação parte, inicialmente, das experiências vividas enquanto professor de Geografia no ensino estadual e ensino municipal na zona Sul da cidade de São Paulo, entre o período de 1996 a 2012. Nessa trajetória profissional, os trabalhos vivenciados no ensino fundamental indicavam insuficiências em muitas questões. Destas, as questões que apontavam para a Educação de Jovens e Adultos - EJA mereceram destaque e se tornaram o foco desta pesquisa.

$O$ atual objeto de pesquisa emergiu da experiência com Educação Jovens e Adultos no Ensino na Rede Estadual Paulista, como professor coordenador pedagógico, entre o ano de 2001 a 2003.

Nessa escola estadual à noite havia aproximadamente 400 estudantes, procedentes de contextos e grupos sociais diversos, o que em certa perspectiva, confrontava-se com os limites da escola e com as interrelações com o bairro e a cidade.

Dessa relação, encontramos situação similar refletida num contexto geral do problema, mas que também permeava a realidade nessa unidade escolar, da qual, os alunos inscritos na EJA tinham de 16 a 60 anos de idade e apresentavam (e ainda apresentam) formação escolar variada e culturas diferentes, decorrentes da inserção ou não ao mundo da produção, à variação das faixas etárias, origem social e regional, permanência de tempo na cidade, da natureza, dos trabalhos exercidos e sindicatos a que se achavam integrados (PONTUSCHKA, 2004).

Os alunos trabalhadores, na maioria dos casos, iam diretamente para a escola depois do trabalho. Por outro lado, os alunos que não trabalhavam, ou se reconheciam como desempregados, também sem completar a escolaridade, necessitavam retornar aos bancos escolares. 
Percebíamos que esse ambiente escolar, em muitos aspectos, não privilegiava a diversidade de interesses e necessidades dos Jovens e Adultos que frequentavam aquela unidade escolar, por vezes, entravam em confronto pela própria diversidade cultural, econômica ou idade o que gerava até mesmo violência.

Com esse quadro desafiador pensávamos, na ocasião, em como criar um projeto educacional que atendesse a tantas demandas e que pudesse ser aproveitado não só para o mercado de trabalho, sobretudo para a vida do aluno.

Da observação e das tentativas de pensar e repensar um trabalho pedagógico que contemplasse essa realidade, percebemos que algumas situações extrapolavam as questões da educação no local, ou, da maneira em que concebiámos a educação de modo geral.

Não compreendíamos como fatores externos ao cotidiano escolar influenciavam a escola e a sala de aula.

Enquanto fenômeno desconhecido, tais problemas se estendiam para além dos muros da escola. A dimensão do problema ainda estava focada no local imediato de trabalho docente, a escola. Considerado esse aspecto, a intenção era continuar os trabalhos com os alunos da EJA, da forma que concebíamos, ou nos concediam, observadas nesta colocação as estruturas educacionais e a organização que as escolas públicas estaduais paulistas estavam sujeitas no período.

As estruturas e organizações controladas pelo Estado em todos os processos educacionais que se davam nas unidades escolares e no interior da sala de aula, justificadas pela manutenção da "ordem" conforme a crítica de Freire (1989), ainda ocorre.

No segundo semestre de 2003 ingressei como professor concursado na rede municipal de São Paulo, numa unidade escolar na mesma localidade, distante cerca de $800 \mathrm{~m}$ da escola estadual. No período 
exonerei o cargo de professor na Rede Estadual onde havia trabalhado como contratado.

A experiência acumulada no ensino estadual, especificamente na EJA, contribuiu para as primeiras vivências nessa modalidade do ensino na Rede Municipal. Entre 2001 a 2010 os problemas relativos à Educação para Jovens e Adultos, naquela localidade de São Paulo aprofundaram-se. Entre os anos de 2007-2008 um drástico esvazimanto nas salas de aula, nos cursos da EJA que, progressivamente, continuaram nos anos seguintes. Esse esvaziamento também ocorreu em toda a cidade de São Paulo.

A diminuição dos alunos nos cursos de EJA não se dava por processo de conclusão dos estudos, muitos não retornavam aos estudos no ano seguinte. Alguns desistiam no meio do caminho e outros não identificávamos as ausências ou motivos das evasões, ou diminuição nas matrículas iniciais, ano a ano.

Nesse momento, as explicações para o esvaziamento nas salas da EJA entre os grupos envolvidos se davam no contexto do "diagnóstico" prescrito por grupos de dirigentes de educação locais, gestores escolares, coordenadores pedagógicos e por parcela dos professores.

Atribuia-se à diminuição de alunos nas salas de EJA e consequente queda no número de salas de aula nas escolas municipais ao despreparo docente no seu trabalho com os alunos da EJA; ao "desinteresse" do aluno pela vida escolar; e às transformações urbanas locais, uma vez que alguns alunos do ensino regular e da EJA haviam pedido transferência por mudança de bairro, em consequência, principalmente de desapropriações.

Alguns trabalhos e pesquisas levantados no percurso desta investigação indicavam forte condicionante sobre a evasão, quedas e diminuição de alunos em EJA e, que também, apontavam sobre o despreparo docente; do conteúdo inadequado; da organização precarizada ao atendimento a esse aluno adulto, jovem e trabalhador; do desinteresse 
do aluno pelas aulas; a incompatibilidade da matriz curricular aos objetivos do curso; a formação precária oferecida ao professor (quando existe); ao distanciamento nas relações aluno e professor; ao distanciamento dos conteúdos do ensino de Geografia em relação às necessidades e expectativas dos alunos; ao distanciamento nas relações mais gerais no âmbito da escola e da sua comunidade; das políticas educacionais municipais que se inserem num momento para desaparecer em seguida; dentre outras tantas questões.

Destas colocações, em muitos aspectos, corroboramos com alguns trabalhos de pesquisa produzidos nos temas citados, dos quais, acessamos no processo inicial de investigação, contextualizados no seu tempo e espaço.

Nesse caminho, observamos sobre a organização e estrutura de funcionamento nos cursos de EJA nas escolas em que atuávamos que, em muitos momentos, sofreram "ajustes" nem sempre apresentando clareza relativa aos objetivos.

A vivência nas escolas públicas nesses períodos de mudanças impôsse por transformações, das quais, os alunos e professores desconheciam os seus objetivos reais.

Nos discursos justificadores das "necessidades por mudanças" desconsideravam todas as experiências protagonizadas pelo aluno e o professor (HADDAD, 2007). Tais discursos são recorrentes e estruturados em argumentos circulares, embasados historicamente no senso comum. É preciso compreensão científica para derrubar a noção linear dos discursos liberais, superá-los pelo conhecimento mais crítico (FREIRE, 2001).

Das leituras realizadas para a pesquisa, alguns documentos e obras, no seu conjunto, auxiliaram a compreensão desses discursos e das consequentes ações dominantes que historicamente se estabeleceram na sociedade brasileira e que foram culturalmente absorvidas. (FRAZÃO 1864; PATO, 1990). 
Dessas incertezas aos objetivos para os cursos de EJA no âmbito municipal, de fato, destacaram-se algumas questões. Para os professores, o afastamento dos alunos da sala e da vida escolar acontecia sutil e progressivamente. A EJA parecia uma modalidade de ensino secundarizada, com relação ao ensino fundamental regular.

Para os gestores dessas unidades escolares, as causas do fracasso pedagógico e da queda das matrículas iniciais na EJA justificavam-se pelo viéis do senso comum, simplificadas nas argumentações mais gerais.

Discurso estabelecido pela complexa superestrutura formada pela Secretaria Municipal de Educação de São Paulo, não levava em conta a construção ou o contexto dessas situações/problemas. Como vimos acima, são fortes as condicionantes consideradas no local, somadas às complexidades que atuam no conjunto dos problemas da escola.

Os problemas da EJA vivenciados nas escolas e apontados em algumas falas dessa pesquisa e dos estudos já realizados por outros pesquisadores indicam fortes condicionantes nas localidades, não abarcam a totalidade, ou seja, quando observados num contexto ampliado e não se sustentam, tratando-se do problema central desta pesquisa, situam-se no seu tempo e espaço.

Nas primeiras incursões da investigação, alguns indícios apontavam realidades semelhantes nos cursos de EJA pelo Brasil, no que se refere aos índices de quedas nas matrículas da EJA, no mesmo período - entre 2007/2008. Tais cursos têm apresentado uma realidade complexa, múltipla e no município de São Paulo não tem sido diferenciado tal aspecto. O consenso entre todos os grupos envolvidos no processo dessas situações/problemas aponta certa desordem dos seus objetivos ou dos seus próprios entendimentos.

Desordem neste momento, tratamos sob os aspectos dos desentendimentos de objetivos e da própria existência dos cursos de EJA protagonizados em âmbito municipal, que muitas vezes, estes, expandem- 
se ou agravam-se entre outras esferas político-administrativas brasileiras e se confundem com os objetivos das gestões governamentais do momento.

Consideradas tais situações, pleiteamos a nossa inserção no Programa de Pós-Graduação em Geografia Humana, em 2010, como possibilidade do entendimento das questões até então levantadas.

$\mathrm{Na}$ busca da questão formulada outras foram emergindo, como: Qual é a linha que delimita o acesso, a continuidade e a queda das matrículas iniciais na EJA? De que maneira a ciência geográfica pode contribuir na elucidação dos problemas apontados? E se o problema central apresentado focaliza-se em outras localidades do território nacional?

Nos anos que seguiram, e a partir de 2008, as impressões sobre o esvaziamento dos cursos de EJA tomaram formas mais concretas. Algumas ações relacionaram-se com algumas destas questões/ problemas, outras não.

Nesse movimento, vimos desde a intervenção de sindicatos dos profissionais da educação municipal nos processos de portarias de atribuição de aulas, editadas pela Secretaria de Educação Municipal de São Paulo, como campanhas por matrículas nos cursos de EJA realizadas pelas unidades escolares.

Constatadas as quedas nas matrículas dos cursos de EJA, notadamente na Educação para Jovens e Adultos em partes da cidade, muitas escolas promoveram campanhas por matrículas. Nessa situação, acirrou-se certa concorrência pela busca por matrículas entre algumas escolas da zona Sul da cidade de São Paulo. Nas Escolas EM. Marina Melander Coutinho, Dr. Miguel Vieira Ferreira e Paulo Setúbal constituímos o nosso campo de investigação a partir do prévio conhecimento da realidade da EJA. Posteriormente esse foi o campo de investigação selecionado. 
Os problemas que envolvem a Educação de Jovens e Adultos no município de São Paulo têm sido objetos de pesquisa nos últimos anos por pesquisadores desta universidade (MOREIRA, 2009; SILVA, R.N. 2013), o que indica realidade complexa, múltipla no atendimento aos cursos de Educação de Jovens e Adultos trabalhadores na cidade de São Paulo, consideradas as escalas e dimensões aos problemas apontamos por estas pesquisas. Destacamos estes autores por desenvolverem suas pesquisas em EJA utilizando-se da Geografia. No trabalho de SILVA, R.N. (2013) acompanhamos o desenvolvimento de sua pesquisa e, em muitos momentos, debatemos alguns pensamentos.

Em Moreira (2009), o autor resgata as políticas públicas para EJA no Brasil, aponta o estudo para a região Metropolitana de São Paulo e analisa o estudo do ProJovem ${ }^{1}$ (2005-2007), registrando um número elevado de desistências e abandono ao curso por motivo de emprego.

Silva, R.N. (2013) focaliza as práticas docentes na EJA paulistana. E constata uma conexão entre as histórias de vida e de formação dos professores da EJA com os seu fazer pedagógico, mas não conseguiu explicar as deficiências pedagógicas observadas nessa modalidade de ensino. Observa a insufuciência do diálogo entre os grupos que compõem a EJA no Município, a saber, entre o professor, o aluno e a Secretaria Municipal de Educação. Em suas considerações, indica-nos a refletir sobre

1 É um programa Federal da Secretaria Nacional da Juventude. O ProJovem Urbano tem como finalidade primeira proporcionar formação integral aos jovens, por meio de uma efetiva associação entre: Formação Básica, para elevação da escolaridade, tendo em vista a conclusão do ensino fundamental; Qualificação Profissional, com certificação de formação inicial; Participação Cidadã, com a promoção de experiência de atuação social na comunidade. O ProJovem Urbano tem duração de 18 meses, oferece formação no ensino fundamental, cursos de iniciação profissional, aulas de informática e auxílio de $\mathrm{R} \$ 100,00$ por mês. O Programa foi concebido como uma intervenção de caráter emergencial destinada a atender parcela significativa dos jovens com o perfil socioeconômico tipificado como público-alvo, que têm necessidade de retomar a trajetória escolar e prosseguir nos estudos. Disponível em: www.projovem.gov.br, em10/10/2012. 
a EJA como um todo, "sobretudo nos profissionais que nela atuam para que seja possível compreendê-la em suas mais varíaveis facetas" (SILVA, R.N., 2013, p. 6).

Nas quedas das matrículas, os grupos envolvidos aferiam que a perda progressiva dos alunos da EJA colocaria em xeque os postos de trabalhos docentes e das gestões nas unidades. Na pesquisa que segue, a nossa proposição focaliza-se na tentativa de ampliar o debate para uma realidade bem mais abrangente que a do local, buscando uma determinante que compreenda os problemas da EJA em sua forma estrutural, sob a reflexão das relações de produção e reprodução do capital.

Nesse caminho, delimitamos como problema central de pesquisa compreender as condicionantes e determinantes pelas quedas nas matrículas iniciais e pela progressiva diminuição no número de salas na Educação de Jovens e Adultos - EJA, na zona Sul da cidade de São Paulo, a partir do ano de 2008.

Para analisar a progressiva queda nas matrículas iniciais da EJA, elencamos os seguintes objetivos específicos:

1. Investigar as condicionantes colocadas pelos professores e gestores como explicação para a queda das matrículas iniciais na EJA, na zona Sul de São Paulo;

2. Buscar as condicionantes externas à escola que pudessem explicar a queda das matrículas na EJA em âmbito regional e nacional, por meio de dados e informações em diferentes fontes governamentais e não governamentais;

3. Analisar as políticas públicas municipais para EJA, suas articulações e os resultados para o cotidiano escolar e a vida dos alunos;

4. Utilizar abordagens quantitativas e qualitativas para conhecer e analisar melhor o processo enfrentado pelas escolas da Cidade Dutra, em relação à diminuição da demanda na EJA. 
No período de 2010 a 2012 aplicamos questionários semiestruturados aos alunos da EJA nas três escolas selecionadas: EM. Marina Melander Coutinho, EM. Paulo Setúbal e EM. Dr. Miguel Vieira Ferreira; entrevista semiestruturada com um professor responsável pelos cursos Municipais da EJA na zona Sul da cidade de São Paulo; além das pesquisas documentais em Portarias, diários de classe, projetos pedagógicos; entrevistas informais ${ }^{2}$; observações em atividades escolares como encontros, palestras, exposições, entre outros, com participação dos alunos e professores da EJA.

Também recorremos aos dados de recenseamentos de institutos oficiais de pesquisas, acessados digitalmente via Internet: IBGE, DIEESE, FIPE, Ministério do Trabalho, PNAD, Secretaria Municipal de Educação de São Paulo.

Organizamos esta dissertação em quatro seções e considerações finais.

1 - Introdução - Breve trajetória da pesquisa; clarificar o objetivo central e específicos da investigação científica e apresentar a organização e estrutura desenvolvidas no trabalho.

2 - Método e Abordagem Metodológica - Esclarecer ao leitor a base epistemológica adotada na pesquisa e que sustentou nossas colocações. Apropriamo-nos do materialismo histórico dialético, enquanto estrutura central de pensamento. Sobre o plano metodológico usamos a Análise de Conteúdos, em Bardin (1977). Nessa perspectiva dividimos a seção em três momentos: "O local inicial da pesquisa"; "As transformações urbanas e os reflexos na vida das escolas" e "A descoberta na queda dos índices de

2 Entrevistas informais no contexto de nossa pesquisa, consideramos os registros dos relatos em horários e dias diversos, sem estruturação formal, mas na conversa intencional direta ou indireta (exploratória), como na sala dos professores; salas de aulas; salas ambientes - Leitura e Informática. Em Bardin (1977, p. 30) tem função heurística: "para ver no que dá". 
matrículas iniciais da EJA em âmbito nacional". Na interpretação dos dados emergiram as categorias Trabalho, Educação e suas contradições.

3 - "O ensino da EJA para além do Município de São Paulo" Ampliamos a pesquisa em escala nacional. Buscamos identificar 0 problema central da pesquisa segundo as condicionantes e as determinantes nas quedas das matrículas iniciais e no esvaziamento das salas de aula nos cursos da EJA de maneira ampliada, totalizante, ou seja, buscamos trabalhar os conceitos de Trabalho, Educação e Contradição sob o enfoque do capital.

4 - "A EJA no contexto Capitalista Brasileiro: Educação, Trabalho e suas contradições", refletir sobre as categorias e analisar o problema sob o enfoque do capital. Do Trabalho, enquanto força produtiva, buscamos o seu entendimento como produção humana. Em seguida introduzimos a formação do Trabalho sob as bases de produção e reprodução do pensamento Lefebvreano, o qual nos apontou em direção aos reais objetivos do Trabalho no capital. Da Educação buscamos refletir sua relação no capital, a qual segundo pensamento Lefebvreano, nos lugares esse espaço não se justapõe enquanto espaço social com o trabalho e suas relações intrínsecas de produção e reprodução (LEFEBVRE, 2006, p. 27). Dessa relação, Educação e Trabalho, analisamos seus movimentos contraditórios construídos historicamente. Nessa análise, estruturamos a seção entre três momentos: "O trabalho nas relações de produção capitalista"; "A Educação de Jovens e Adultos no contexto do capital" e "A Educação para Jovens e Adultos e o caminho às transformações, no capitalismo contemporâneo no Brasil". 


\section{MÉTODO E ABORDAGENS METODOLÓGICAS}

Nesta seção trataremos do Método e das Metodologias que sustentaram esse trabalho. Nosso objetivo aqui é clarificar nossas bases epistemológicas, metodológicas e das concepções quantitativas e qualitativas que adotamos na tarefa de investigação científica.

Investigar as condicionantes e determinantes que contribuíram no esvaziamento dos cursos de EJA no Município de São Paulo, remete-nos a perceber essa realidade sob o do materialismo dialético.

Buscamos no início da investigação, nas unidades escolares selecionadas, explicações às questões que originaram este estudo. Como hipóteses provisórias, no período, elencamos questões que não sustentaram as primeiras incursões no processo investigativo.

Da observação em campo surgiu a necessidade de rever a metodologia até então adotada, e nesse aspecto, ampliar as abordagens na pesquisa. Nesse contexto, ampliamos também a escala de investigação, foi necessário sair da escola. Na investigação emergiram outras questões das quais algumas se confirmaram e outras que se infirmaram ${ }^{3}$. O desenvolvimento desse processo é o que veremos adiante.

\section{1 - O MÉTODO}

Nesse trabalho fez-se necessária a busca por desvendar os movimentos que constituiram a realidade dos cursos de EJA no presente e dos caminhos percorridos por esses cursos. Refletir nos atuais resultados de declínio nas matrículas iniciais, observados de maneira empírica num primeiro momento e, a seguir, trazidos à luz da cientificidade.

\footnotetext{
${ }^{3}$ De infirmação - infirmaram - termo utilizado por Bardin (1977, p.30) em análise de conteúdo para as hipóteses provisórias não confirmadas no processo de "administração de provas" e que o adotaremos como termo e, nessa dimensão, enquanto referencial teórico.
} 
Para essa empreitada direcionamos as bases epistemológicas em Henri Lefebvre (1901-1991) um dos primeiros a divulgar o pensamento marxista em todo o mundo, que a seu tempo, reflete sobre as questões políticas, econômicas e sociais do século XX. Concepção de mundo pela qual corroboramos e apropriamo-nos como norteadora do pensamento neste trabalho.

Em Lefebvre (2010) a concepção de mundo recusa uma hierarquia exterior ao indivíduo, metafísica, ou individualista - trata-se de consciência individual e do exame individual dessa consciência. Essa concepção está baseada nas realidades naturais - da natureza, do mundo exterior; das práticas - trabalho e ação; sociais e históricas - estrutura econômica da sociedade, classes sociais, etc. Rejeita, deliberadamente, a subordinação prévia imóvel e imutável dos elementos do homem e da sociedade uns aos outros, nem admite uma harmonia espontânea. Todos os elementos estão em constante movimento.

Esse movimento caracteriza-se pela existência de contradições tanto do homem quanto da sociedade humana, na qual o interesse individual privado - pode e opõe-se frequentemente ao interesse comum - coletivo.

Falar de contradições é também falar de problemas a resolver, portanto, segundo Lefebvre (2010, p. 12) é tratar de luta e ação, possibilidades de passos à frente, de vitória.

É dessa base que elevamos o pensamento em direção à desocultação dos fenômenos que se manifestam na EJA e da sua realidade.

Partir para pesquisa em EJA considerando o aspecto da vivência da docência compõe, em alguns aspectos, não somente da nossa afinidade com o tema-problema, mas em considerável vantagem no entendimento do objeto a ser investigado. Partir daquilo que já conhecemos representa significativo caminho percorrido na compreensão a tudo que emergir na 
pesquisa. "Quanto mais profundo é o conhecimento geral, mais fácil a pesquisa específica" (NEUMANN, 2008, p. 63, tradução nossa).

Com o prévio conhecimento em EJA, ao adentrar nos aspectos mais empíricos da nossa empreitada, percebemos algumas lacunas para o prosseguimento da pesquisa. Também alguns equívocos de nossa parte foram revelados, aos quais a todo o tempo, levou-nos a repensar sobre os procedimentos metodológicos a serem adotados e a delimitar o objeto de pesquisa possível de investigar.

Investigar sobre os altos índices de queda nas matrículas nos cursos de EJA a partir do ano de 2008, nas escolas da zona Sul da cidade de São Paulo onde atuávamos, evidenciou a diminuição drástica nas matrículas nos cursos de EJA em todo o município de São Paulo, no período citado. Como veremos a seguir:

Tabela 1

RESULTADOS FINAIS DO CENSO ESCOLAR

MATRÍCULAS - PERÍODO 2001-2012

MUNICÍPIO DE SÃO PAULO - EJA - PRESENCIAL

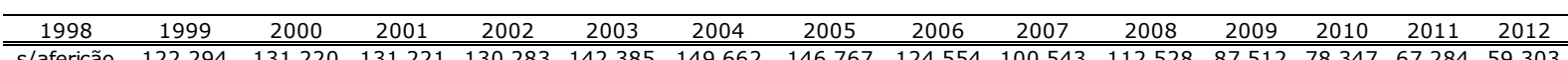

FONTE: INEP - Sistema de Consulta à Matrícula do Censo Escolar - 1997-2012.

Organizado por SOUZA, M.R., 2012.

Estes dados em si não apontavam mais do que nossas impressões iniciais. Havíamos constatado, de maneira geral, o esvaziamento dos cursos de EJA. Tratando de pesquisa qualitativa, necessitávamos buscar em tais números o que ocultavam.

Para a tarefa de desocultação adotamos a análise de conteúdos. Tal metodologia atuou neste trabalho como "ponte" entre os dados quantitativos, na sua descrição numérica de algumas características do corpo do texto e, qualitativa, enquanto análise dos materiais (GUTBERLET, 2010).

Para a organização dos dados quantitativos, sob a análise de conteúdos, recorremos a Bardin (1977) como importante caminho de 
comprovação na sustentação da hipótese provisória, o que gerou significativa quantidade de dados estatísticos.

Das entrevistas, questionários semiestruturados e a entrevista semiestruturada, buscamos pelos dados qualitativos. A partir de algumas constatações, nos momentos iniciais da pesquisa algumas hipóteses afirmavam-se, para num momento seguinte, não se sustentarem.

As questões metodológicas entre pesquisas de abordagens qualitativas e quantitativas para esse autor elucidam-se da seguinte maneira:

[...] Na análise quantitativa, o que serve de informação é a frequência com que surgem certas características de conteúdo. $\mathrm{Na}$ análise qualitativa é a presença ou a ausência de uma dada característica de conteúdo ou de um conjunto de características num determinado fragmento de mensagem que é tomado em consideração (BARDIN, 1977, p. 21).

Bardin (1977, p. 28) apontou um ponto de partida fundamental nessa empreitada investigativa: tomar da experiência em EJA, hipóteses/problemas apresentados, porém tomando 0 cuidado de, conduzidos por um pressuposto metodológico, recusar ou tentar afastar os perigos da compreensão espontânea, da destruição da intuição em proveito do "construído". Estar em atitude de "vigilância crítica". Esse caminho nos exige o rodeio metodológico e o emprego de "técnicas de ruptura", considerando-se a familiaridade ante o nosso objeto de estudo.

Vale esclarecer neste momento, que recorrer à obra de Bardin (1977), apesar de traduções mais recentes, intencionalmente, foi motivo de nossa apropriação da sua primeira tradução do francês para o português Luso, o que acreditamos apreender com proximidade às suas mensagens, e também por se tratar de um minucioso "passo-a-passo" para os iniciantes.

A Análise de Conteúdo em Laurence Bardin (1977) contempla as lacunas metodológicas buscadas, até então, rumo à continuidade deste 
trabalho, o que possibilitou avanço e compreensão no prosseguimento da pesquisa em bases metodológicas mais consistentes e, porque não coerentes na coleta, organização, análise e interpretação dos dados da pesquisa.

Nesse caminho de apropriação em análise de conteúdo, recorremos às explicitações de Bardin e ao seu conceito:

[...] um conjunto de instrumentos metodológicos cada vez mais suptis em constante aperfeiçoamento, que se aplicam a "discursos" (conteúdos e continentes) extremamente diversificados. [...] é uma hermenêutica controlada, baseada na dedução: a inferência. Enquanto esforço da interpretação, a análise de conteúdo oscila entre os dois pólos do rigor da objectividade e da fecundidade da subjectividade. Absolve e cauciona o investigador por esta atracção pelo escondido, o latente, o não-aparente, o potencial inédito (do não dito), retido por qualquer mensagem. Tarefa paciente de "desocultação" [...] (BARDIN, 1977, p. 9).

A análise de conteúdo no início do século XX permeou as ciências de estudo das comunicações nos Estados Unidos, sob epistemologia positiva. Do seu desenvolvimento até os nossos dias sofreu profundas alterações, com destaque entre o período de 1940-1950, no qual tanto epistemológica quanto metodologicamente, assumem papel de destaque no campo de muitas áreas do conhecimento científico, após de (re) sistematizadas as suas regras e redefinidos os pressupostos de sua sustentação teórica.

Nas quatro primeiras décadas do século $X X$ a análise de conteúdo pronunciou-se enquanto instrumento de análise na comunicação, essencialmente jornalísticos, tendo como berço a Escola de Jornalismo de Colúmbia, com estudos quantitativos dos jornais.

Após a II Guerra Mundial, nos Estados Unidos os departamentos de ciências políticas deram destaque ao desenvolvimento da análise de conteúdos na tentativa de desmascarar os jornais e periódicos suspeitos de propaganda subversiva. No período, $25 \%$ dos estudos empíricos relatam sobre o seu uso para fins de investigação política. 
Bardin (1977, p. 22) descreve duas iniciativas que foram fundamentais no processo de "desbloqueio" à análise do conteúdo no plano metodológico:

- a exigência da objetividade torna-se menos rígida. Do legado passado, alguns investigadores confundiam objetividade com cientificidade, na minuciosa tarefa das análises de frequências.

- a aceitação entre a combinação da compreensão clínica com a contribuição estatística. A análise do conteúdo deixa de ser considerada apenas em um alcance descritivo, toma consciência de que sua função ou o seu objetivo é a inferência. Observa-se que esta inferência se realize tendo como base os indicadores de frequência com indicadores combinados (análises da co-ocorrências). Toma-se consciência de que a partir dos resultados da análise, possa se regressar às causas, ou descer aos efeitos das características das comunicações.

Na pesquisa de campo colhemos material para análise por meio de entrevistas com professores e representantes regionais de educação; questionários e relatos informais com alunos e professores e levantamento de documentos oficiais fornecidos pelas unidades escolares e DRE.

Como ampliação do campo de investigação e das necessidades de comprovação, realizamos pesquisa sob os meios de comunicação oficiais em rede de Internet da Secretaria de Educação do Município de São Paulo e órgãos Federais como INEP - Instituto Nacional de Estudos e Pesquisas Educacionais "Anísio Teixeira" e no IBGE - Instituto Brasileiro de Geografia e Estatística.

Buscamos alguns referenciais em trabalhos de EJA produzidos por pesquisadores em Programas de Pós-Graduação Strictu Sensu realizados no Brasil nas áreas da Geografia e Educação.

As atividades de campo buscaram pelas respostas dos objetivos da pesquisa e delimitaram o procedimento metodológico. Colhidos os 
primeiros materiais em campo, nas primeiras leituras em Bardin (1977, p. 34), observamos que se tratando de análise de conteúdo, a Descrição Analítica apresentou-se como primeiro procedimento.

Funcionou segundo procedimentos sistemáticos e objetivos de descrição do conteúdo das mensagens. Um tratamento da informação contida nas mensagens, uma análise dos "significados", podendo ser também uma análise dos "significantes" (léxica ou dos procedimentos).

Dos domínios que a análise de conteúdo se insere, segundo Bardin (1977, p. 35), destacamos:

Códigos e suporte - monólogos, diálogos, de grupos restritos e de comunicação de massa, sendo:

\section{Linguísticos}

Escritos: Agendas, diários íntimos, cartas, respostas a questionários, trabalhos escolares, todas as comunicações escritas trocadas dentro de um grupo, jornais, livro, panfletos e textos jurídicos.

Oral: Delírios do doente mental, sonhos, entrevistas e conversações de qualquer espécie, discussões, conversações em grupo de qualquer natureza, exposições, discursos, rádio, televisão, cinema, publicidade e discos.

Icônicos (sinais, grafismos, imagens, fotografias, filmes, etc.)

Garatujas mais ou menos automáticas, grafitos, sonhos, comunicação entre duas pessoas através da imagem, respostas aos testes projetivos, toda a comunicação icônica num pequeno grupo, sinais de trânsito, cinema, publicidade, pintura, cartazes, televisão.

Outros Códigos Semióticos (tudo que não sendo linguístico, pode ser portador de significações; ex.: música, código olfativo, objetos diversos, comportamentos, espaço, tempo, sinais patológicos, etc.) 
Manifestações histéricas da doença mental, posturas, gestos, tiques, dança, coleções de objetos, comunicação não verbal com destino a outrem, comportamentos diversos, meio físico e simbólico, mitos, estereótipos, instituições e elementos de cultura.

Bardin (1977, p. 34-36) ainda nos esclarece que certas definições sobre a Análise de Conteúdo insistem sobre o aspecto manifesto nas comunicações como de caráter sistemático e quantitativo nos seus procedimentos, mas não se trata de renegar o aspecto da técnica, é compreender que nas ciências humanas este não é o seu único objetivo.

Enfim, análise de conteúdo nos remete a um trabalho exaustivo com suas divisões, cálculos e aperfeiçoamentos, mas esses "pacientes rodeios; inventários metódicos e cálculos de frequências estatísticas" conduzem ao rigor e às descobertas; leva-nos a ultrapassar as incertezas e enriquecer a leitura (BARDIN, 1977, p. 28-30).

Dentro deste vasto campo de domínio abarcado pela análise de conteúdo, vimos possibilidades de confrontar ou complementar os procedimentos metodológicos e a teoria, segundo o objeto da presente pesquisa.

Nesse caminho, observamos na Tabela 1 que os dados necessitavam revelar algo ainda "oculto, nebuloso". Foi o momento de não nos deixar levar pelos perigos da "compreensão espontânea"; a "falsa segurança dos números". Iniciar neste momento a "vigilância crítica" ao que se quer observar (BARDIN, 1977, p. 28-29).

Trouxemos os dados iniciais de queda nas matrículas sob outras bases exploratórias e de observação, buscando encontrar pistas para a o avanço na investigação: 


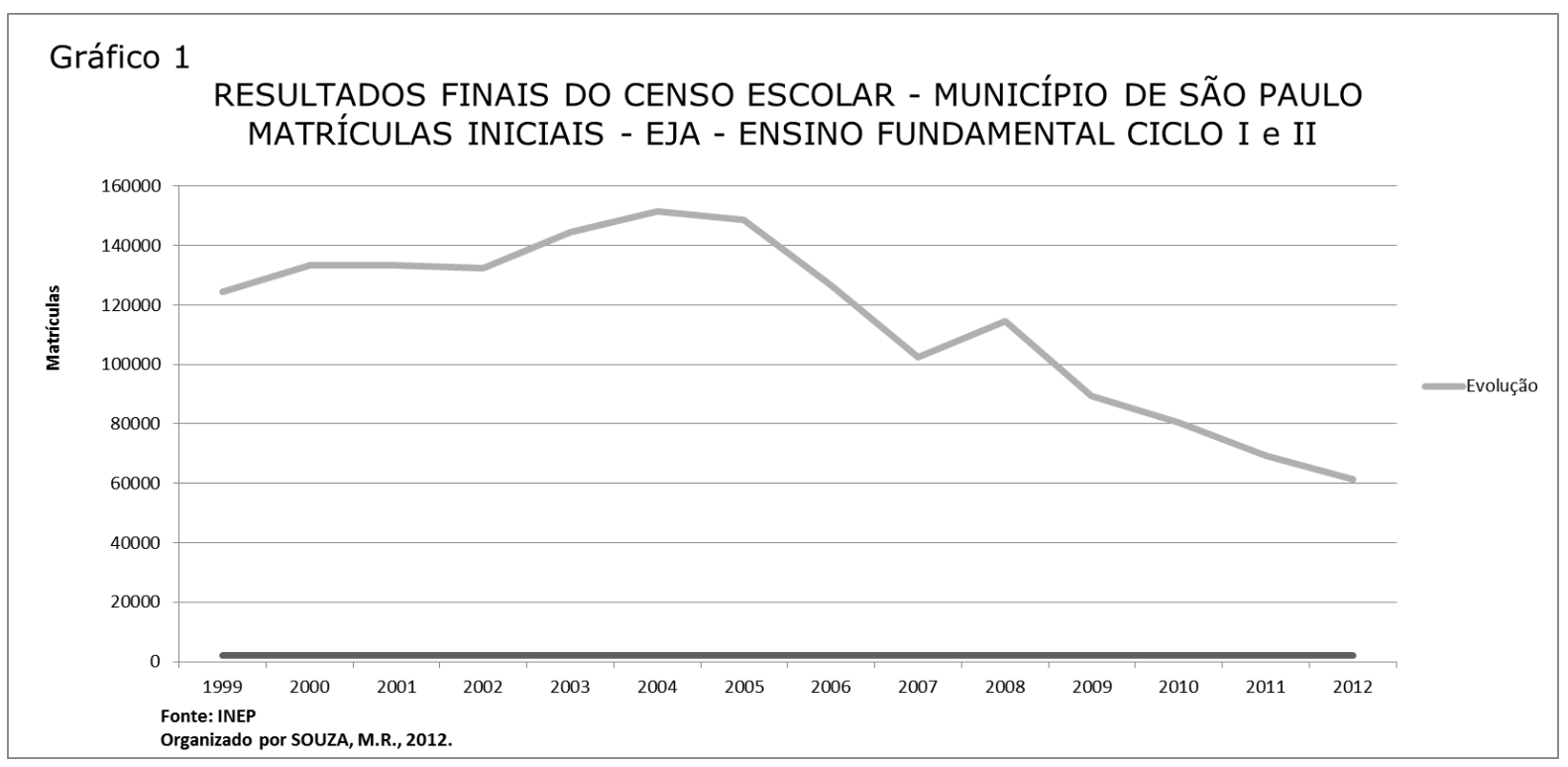

Percebemos então que o ano de 2008 evidenciava o início de uma crescente queda no número de matrículas na EJA do Município de São Paulo. Decidimos então levantar em que índices essas matrículas caíram, então, recorremos aos cálculos estatísticos com base Ano/Ano, entre 1999 a 2012, e obtivemos os seguintes resultados:

\begin{tabular}{|c|c|c|c|c|c|c|c|c|c|c|c|c|c|c|}
\hline \multirow[b]{2}{*}{1998} & \multicolumn{14}{|c|}{ Evolução das Matrículas - \% ANO/ANO - entre 1999 - 2012} \\
\hline & 1999 & 2000 & 2001 & 2002 & 2003 & 2004 & 2005 & 2006 & 2007 & 2008 & 2009 & 2010 & 2011 & 2012 \\
\hline & 122.294 & 131.220 & 131.221 & 130.283 & 142.385 & 149.662 & 146.767 & 124.554 & 100.543 & 112.528 & 87.512 & 78.347 & 67.284 & 59.303 \\
\hline $\begin{array}{c}\% \\
\text { Evolução } \\
\text { Matrículas } \\
\text { Ano/Ano } \\
\end{array}$ & * & 7,30 & 0,00 & $-0,71$ & 9,29 & 5,11 & $-1,93$ & $-15,13$ & $-19,28$ & 11,92 & $-22,23$ & $-10,47$ & $-14,12$ & $-11,86$ \\
\hline
\end{tabular}

Apesar de já se apresentarem entre oscilações antes de 2008, os índices a partir do ano de 2008 demonstraram predominância de evolução negativa nas matrículas em EJA no Munícipio de São Paulo. A hipótese provisória nos induzia a essa redução à desastrosa Reorganização no ano de 2008 da EJA e que tratamos num capítulo à parte.

Até esse momento da investigação perguntávamos: O planejamento e execução dessa Reorganização seria a determinante por tamanha queda nos índices de matrículas na cidade de São Paulo? Buscamos ampliar nossa investigação e buscar nas variáveis em âmbito nacional algum 
ponto de comprovação, ou não, ao que os números na cidade de São Paulo apresentavam:

\section{TABELA 3}

MATRÍCULAS INICIAIS - EJA - FUNDAMENTAL I e II - POR ESTADOS

BASE DOS DADOS: TOTAIS ( FEDERAIS, ESTADUAIS, MUNICIPAIS E PRIVADAS)

PERÍODO: 2000 A 2012.

Por índices de quedas e aumentos.

\begin{tabular}{|c|c|c|c|c|c|c|c|c|c|c|c|c|c|}
\hline ESTADOS & 2000 & 2001 & 2002 & 2003 & 2004 & $\begin{array}{l}\text { ANO } \\
2005\end{array}$ & 2006 & 2007 & 2008 & 2009 & 2010 & 2011 & 2012 \\
\hline AC & 19.694 & 41.851 & 37.426 & 38.029 & 35.961 & 31.436 & 27.971 & 21.180 & 19.184 & 17.092 & 16.190 & 16.619 & 19.859 \\
\hline AM & 53.705 & 59.417 & 74.926 & 75.827 & 80.053 & 88.380 & 94.684 & 82.269 & 70.030 & 67.691 & 63.108 & 63.832 & 62.385 \\
\hline $\mathbf{A L}$ & 36.255 & 77.762 & 91.191 & 95.828 & 99.501 & 101.386 & 105.283 & 92.133 & 91.066 & 99.302 & 85.411 & 97.327 & 88.672 \\
\hline AP & 26.527 & 24.787 & 23.249 & 22.312 & 23.799 & 22.386 & 21.539 & 17.868 & 17.386 & 16.731 & 16.851 & 17.360 & 16.619 \\
\hline BA & 8.841 & 43.776 & 84.397 & 105.020 & 373.362 & 387.828 & 391.306 & 370.007 & 377.339 & 364.619 & 327.836 & 317.973 & 300.084 \\
\hline CE & 124.233 & 184.910 & 189.910 & 207.586 & 229.106 & 228.666 & 234.881 & 175.297 & 156.524 & 141.988 & 123.197 & 117.725 & 115.724 \\
\hline DF & 68.868 & 66.369 & 19.009 & 16.282 & 14.268 & 12.074 & 40.074 & 33.075 & 33.574 & 27.946 & 26.800 & 28.249 & 26.959 \\
\hline ES & 50.712 & 54.619 & 50.446 & 52.448 & 48.229 & 37.730 & 34.029 & 28.735 & 31.602 & 35.737 & 37.654 & 37.362 & 37.971 \\
\hline GO & 42.535 & 58.053 & 82.210 & 89.503 & 86.289 & 76.076 & 67.029 & 50.072 & 46.696 & 41.349 & 44.726 & 37.592 & 34.105 \\
\hline MA & 75.672 & 120.258 & 168.621 & 274.631 & 225.038 & 221.776 & 225.883 & 184.384 & 172.968 & 171.758 & 162.783 & 155.954 & 142.526 \\
\hline MT & 18.943 & 23.307 & 27.366 & 20.999 & 18.121 & 32.540 & 55.642 & 55.111 & 54.345 & 57.303 & 62.182 & 62.466 & 55.376 \\
\hline MS & 34.410 & 3.335 & 9.488 & 46.435 & 42.620 & 44.267 & 45.950 & 44.448 & 47.710 & 46.588 & 27.802 & 26.474 & 22.170 \\
\hline MG & 23.460 & 43.884 & 45.971 & 52.127 & 64.018 & 90.437 & 132.018 & 166.981 & 178.674 & 162.701 & 156.618 & 144.014 & 137.635 \\
\hline PA & 188.035 & 231.770 & 253.951 & 265.865 & 275.515 & 283.007 & 272.812 & 231.270 & 217.641 & 221.660 & 211.910 & 198.523 & 193.944 \\
\hline PB & 44.055 & 62.925 & 93.677 & 118.847 & 132.410 & 142.591 & 150.812 & 112.704 & 110.181 & 104.023 & 99.608 & 101.931 & 103.615 \\
\hline PR & 167.449 & 146.991 & 106.041 & 104.413 & 70.239 & 60.033 & 98.519 & 111.174 & 106.681 & 90.932 & 91.401 & 80.498 & 82.878 \\
\hline PE & 134.078 & 173.129 & 213.232 & 239.832 & 262.879 & 262.023 & 273.102 & 236.286 & 235.759 & 223.117 & 215.919 & 192.815 & 180.450 \\
\hline PI & 28.490 & 80.507 & 113.655 & 150.492 & 136.264 & 125.188 & 133.218 & 91.624 & 90.122 & 88.396 & 77.733 & 69.493 & 64.417 \\
\hline RJ & 217.921 & 184.179 & 216.200 & 228.064 & 247.707 & 239.948 & 237.338 & 217.740 & 221.927 & 207.620 & 209.134 & 173.091 & 147.278 \\
\hline RN & 75.681 & 103.904 & 116.697 & 126.729 & 130.381 & 128.029 & 117.815 & 94.414 & 82.249 & 74.508 & 74.988 & 73.838 & 67.485 \\
\hline RO & 36.010 & 33.330 & 47.063 & 49.258 & 45.222 & 39.714 & 38.133 & 34.118 & 33.344 & 36.031 & 34.086 & 30.398 & 28.631 \\
\hline RR & 6.715 & 16.307 & 13.642 & 20.734 & 17.397 & 15.068 & 11.345 & 8.073 & 7.167 & 5.018 & 6.336 & 4.921 & 5.081 \\
\hline RS & 97.239 & 93.785 & 100.574 & 104.681 & 114.373 & 115.712 & 114.354 & 104.076 & 96.085 & 89.474 & 85.933 & 83.586 & 82.863 \\
\hline SC & 89.946 & 97.175 & 69.847 & 64.577 & 58.087 & 33.918 & 64.293 & 49.739 & 39.370 & 44.123 & 37.904 & 35.826 & 30.026 \\
\hline SE & 35.571 & 41.473 & 52.541 & 58.990 & 62.601 & 68.326 & 62.641 & 56.016 & 51.118 & 45.639 & 42.659 & 41.307 & 41.332 \\
\hline SP & 562.281 & 564.456 & 444.507 & 463.869 & 487.875 & 473.417 & 433.056 & 370.185 & 373.505 & 316.444 & 253.743 & 220.708 & 196.678 \\
\hline TO & 5.788 & 38.799 & 47.177 & 47.860 & 38.360 & 33.611 & 32.498 & 22.053 & 16.527 & 12.948 & 11.756 & 11.313 & 10.944 \\
\hline \multicolumn{14}{|c|}{ Fonte: INEP - Matrículas Iniciais - Fundamental I e II } \\
\hline 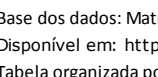 & 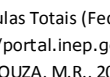 & & & Vadad & & & & & & & & & \\
\hline
\end{tabular}

A observação da tabela foi o primeiro indício de que a queda nas matrículas da EJA no Município de São Paulo não se tratava de caso isolado da cidade de São Paulo. Os índices nas matrículas iniciais da EJA caíram em todos os estados da Federação, demonstram que o ano de 2007 registraram as maiores quedas e, seguem, predominantemente, em quedas.

Para analisar essa tabela, consideramos sua análise sob 02 períodos: entre 2000-2012 e a partir de 2008 que foi a grade temporal recortada, a partir da Reorganização do Município de São Paulo. 
Considerados os dois períodos, as matrículas apresentam-se sob os seguintes níveis - Quedas; Oscilações; Constância e Ascendência. Vejamos nos quadros comparativos a seguir:

\begin{tabular}{|c|c|}
\hline $\begin{array}{l}\text { Quadro 1 } \\
\text { Compara }\end{array}$ & $\begin{array}{l}\text { lo de Matrículas na EJA por Estados - em Níveis } \\
\text { eríodo - Entre } 2000 \text { a } 2012\end{array}$ \\
\hline Quedas: & AC; AP; CE; DF; ES; GO; MA; MS; PR; PI; SP; RR; RJ; RN; TO \\
\hline Oscilações: & AM; AL; MG; PA; PB; PE; SC \\
\hline Constâncias: & RO; RS; $\mathrm{SE}$ \\
\hline Aumentos: & BA; MT \\
\hline
\end{tabular}

Fonte: INEP - Base dos dados: Tabela 003

Elaborado por SOUZA, M.R., 2012.

Entre 2000 - 2012 - Predominam as Quedas do número das matrículas nos cursos de EJA, em 15 Estados. As Oscilações aparecem com uma tendência em queda nas matrículas, no período, em 7 Estados. As Constâncias nos números de matrículas oscilam para quedas em dois, dos três Estados apontados: Rondônia e Rio Grande do Sul, mantendo-se estáveis no Sergipe. Somente na Bahia e Mato Grosso os números de matrículas seguem ascendentes, com a seguinte diferença entre estes Estados: Na Bahia houve significativo aumento no número de matrículas entre 2001 a 2006, depois a tendência seguiu em queda, mas conservando-se os altos índices de matrículas. No Mato Grosso as matrículas seguem entre oscilações e ascendências.

Nos dois Estados, até o fim do período de 2012 as matrículas se mantêm em números muito superiores ao período inicial da análise, no ano 2000.

Quando passamos a analisar as matrículas dos Estados brasileiros em EJA a partir do ano de $\mathbf{2 0 0 8}$, percebemos uma forte queda na maioria dos Estados brasileiros. Consideramos os níveis de oscilações e constâncias, predominantemente em queda, quase na totalidade dos Estados. 


\begin{tabular}{|l|l|}
\hline $\begin{array}{l}\text { Quadro } 2 \\
\text { Comparativo de Matrículas na EJA por Estados - em Níveis } \\
\text { Período - Entre 2008 a 2012 }\end{array}$ \\
\hline \hline Quedas: & $\mathrm{AM} ; \mathrm{AP} ; \mathrm{BA} ; \mathrm{CE} ; \mathrm{DF} ; \mathrm{GO} ; \mathrm{MA} ; \mathrm{MS} ; \mathrm{MG} ; \mathrm{PA} ; \mathrm{PR} ; \mathrm{PE} ; \mathrm{PI}$ RJ; RN; RO; RR; RS; \\
& $\mathrm{SC} ; \mathrm{SE} ; \mathrm{SP} ; \mathrm{TO}$ \\
\hline Oscilações: & $\mathrm{AC} ; \mathrm{AL} ; \mathrm{PB}$ \\
\hline Constâncias: & $\mathrm{ES}$ \\
\hline Aumentos: & $\mathrm{MT}$ \\
\hline
\end{tabular}

Fonte: INEP - Base dos dados: Tabela 003

Elaborado por SOUZA, M.R., 2012.

Nessa situação aprofundam-se as Quedas de matrículas em 22 Estados. As Oscilações mantêm-se nos estados: Acre, Alagoas e Paraíba. No nível de Constâncias permanece o Espírito Santo. O Estado do Mato Grosso manteve-se ascendente, mas com oscilações quando comparado aos demais Estados. A Bahia manteve os seus altos números de matrículas nos dois períodos.

O que trazíamos enquanto hipótese provisória: A queda do número de matrículas vinculada à Reorganização da EJA no Município de São Paulo já não se sustenta neste momento da pesquisa.

A partir desse ponto da pesquisa tivemos que aprofundar a reflexão das hipóteses provisórias. O que se apresentou até aqui indica como hipótese emergente (BARDIN, 1977, p. 96) a presença de um fenômeno que abarca os cursos de EJA, independentemente das circunstâncias locais, parece agir como determinante ou condicionante nos processos de queda nas matrículas, não só no município de São Paulo, mas estende-se pelo Estado de São Paulo e Brasil.

Voltamos então para os nossos dados de campo. Entrevistas e questionários realizados nas escolas selecionadas e Diretoria Regional. O repensar os dados e cruzar as informações até aqui foi crucial para elaborar outras hipóteses que se sustentassem, provisoriamente, e seguir na busca de uma consistente resposta à crescente queda nas matrículas da EJA no Brasil e que pudesse ser validada. 
Os dados do Estado de São Paulo entre 2007-2012 refletem o Brasil. Esse exercício comparativo foi importante para perceber as frequências dos fenômenos e delas, partir para algumas prévias deduções.

Nesse momento da pesquisa e da nossa busca decidimos "reduzir", ou seja, retornar pelos dados em nível local, nas escolas da zona Sul da cidade de São Paulo onde atuamos nos dez últimos anos em Educação de Jovens e Adultos. Essa redução, necessária ao empirismo do trabalho de campo, talvez, trouxesse mais subsídios para as descobertas.

\section{2 - DO LOCAL INICIAL DA PESQUISA}

As atividades de pesquisa de campo se deram a partir do mês de agosto de 2010 em Escolas municipais do Ensino Fundamental próximas ao Autódromo de Interlagos, que se destacam na Educação de Jovens e Adultos: EM. Profa. Marina Melander Coutinho, EM. Paulo Setúbal e EM. Dr. Miguel Vieira Ferreira, pertencentes à Diretoria Regional de Educação da Capela do Socorro - São Paulo, na capital.

Essas três unidades escolares foram escolhidas porque eu acompanhei seus trabalhos, sua história e o desenvolvimento pedagógico da Educação de Jovens e Adultos, entre 2002-2010, enquanto professor municipal em São Paulo. Também é importante destacar a proximidade geográfica dessas escolas e dos programas de incentivo à matrícula que cada uma delas desenvolveu a partir da constatação do quadro de diminuição das matrículas desde 2008, o que acirrou certa "concorrência" entre as escolas mencionadas por disputarem as matrículas dos alunos de EJA na zona Sul.

O mapa n. 1 refere-se às Subprefeituras da cidade de São Paulo, com destaque para a Capela do Socorro e o Bairro da Cidade Dutra, na zona Sul, foco desta pesquisa: 


\section{MAPA 01}

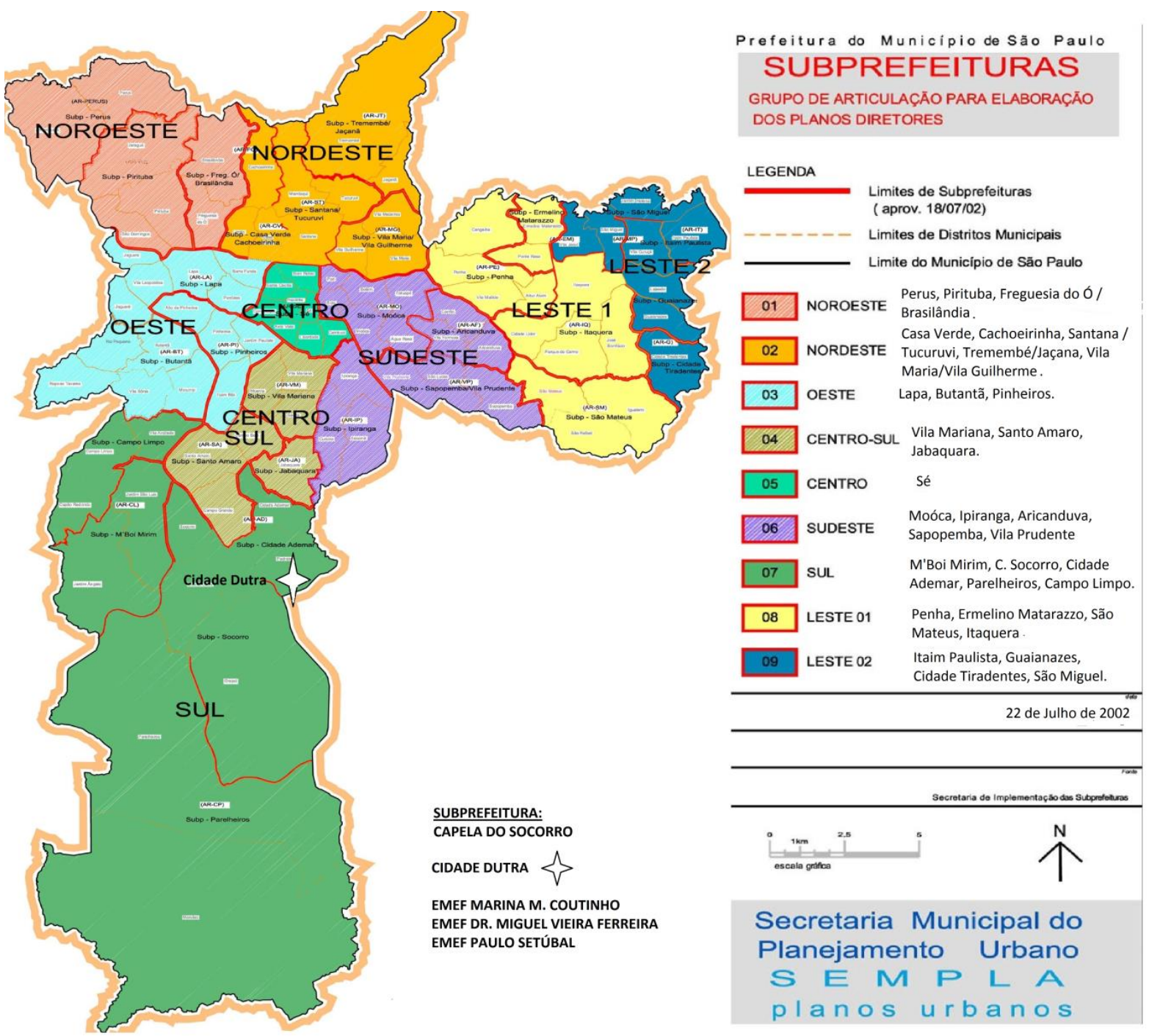

Fonte: Secretaria Municipal do Planejamento Urbano - SEMPLA, 2002.

Adaptação: SOUZA, M.R., 2012.

Para entender o local da pesquisa recorremos à História da Capela do Socorro, ponto de partida de nossas preocupações teóricas nessa empreitada. O desenvolvimento urbano e econômico deste distrito está inserido no crescimento e nas mudanças que ocorreram na região metropolitana de São Paulo.

Entender o que é hoje uma área ocupada por cerca de 200 bairros irregulares e 220 favelas encravadas em áreas de Proteção de Mananciais é procurar entender as profundas contradições que a cidade enfrenta nos 
processos de seu desenvolvimento econômico, à custa de sacrifícios sociais e ambientais.

No reconhecimento da Capela do Socorro, resgatamos documento da Prefeitura de São Paulo, disponibilizado pela página Oficial na Internet ${ }^{4}$, que revela alguns aspectos de sua formação. Coloco, a seguir, alguns aspectos considerados de importância no entendimento da formação da atual Subprefeitura da Capela e do bairro de Cidade Dutra, extraídos do site:

A Capela do Socorro estende-se por uma vasta área ao sul dos canais dos Rios Jurubatuba e Guarapiranga, pertencentes à bacia do Rio Pinheiros.

É formada pelos distritos de Socorro, Cidade Dutra, Grajaú, com uma superfície de $134 \mathrm{Km}^{2}$, que corresponde a 8,8\% do território no município. Cerca de $90 \%$ de seu território está inserido em área de Proteção aos Mananciais Aquíferos responsáveis pelo abastecimento de $30 \%$ da população da região metropolitana de São Paulo.

A ocupação da Capela do Socorro está estreitamente relacionada à expansão e estruturação urbanas da Subprefeitura de Santo Amaro, à qual esteve administrativamente ligada até 1985.

Diferentemente do cenário que presenciamos hoje, esta região era habitada pelos índios tupis, que ocupavam também vários pontos da região sul do Brasil, além do litoral. No século XX, os guaranis, subgrupo tupi, no curso de seu processo migratório, chegaram a Parelheiros e lá se

4 "Conheça um pouco da história da Capela do Socorro" - In
http://prefeitura.sp.gov.br/cidade/secretarias/subprefeituras/capela
socorro/historico/index.php?p=916, em $27 / 10 / 2012$.


fixaram. Remanescentes desse núcleo são as duas aldeias existentes na área da Subprefeitura de Parelheiros: a de Curucutu e a do Morro da Saudade que juntas perfazem cerca de 600 indígenas.

Outras referências à Capela do Socorro são encontradas em documentos dos anos que se seguiram à Independência do Brasil (1822), época em que foram realizadas tentativas de atrair para o Brasil a imigração europeia.

Em 1827-1828 desembarcaram em Santos os primeiros grupos de colonos alemães, dentre os quais se destacaram pouco mais de 120 que aceitaram terras devolutas em Santo Amaro, localizadas em Colônia, na Subprefeitura de Parelheiros.

Ao contrário das colônias alemãs no sul do Brasil, esta não conseguiu preservar muitos aspectos de sua tradição cultural e quase nada resta dessa experiência colonizadora, apenas algumas famílias como Schunk, Reemberg, Roschel, Hessel, entre outras, que ainda residem no local. Nas primeiras décadas do século $X X$, após a construção das barragens da Light ${ }^{5}$ : em 1907, e a do rio Guarapiranga, dando origem à represa que ocupa área de $33,9 \mathrm{Km}^{2}$, com a finalidade principal de regularizar a vazão do rio Tietê e garantir a geração de energia na Usina Edgard de Souza em Santana de Parnaíba; e, a do Rio Grande, construída após a grande seca de 1924, que deu origem à represa Billings, e ocupa área de $130 \mathrm{Km}^{2}$ entre São Paulo e São Bernardo do Campo.

\footnotetext{
${ }^{5}$ Há 100 anos a Light chegou ao Brasil. Autorizada a funcionar em 17 de Julho de 1899, o empreendimento que assinala o início das atividades do Grupo Light no Brasil é a Usina Hidrelétrica Parnaíba, no Rio Tietê, construída entre 1899 e 1901. Para atuar na então Capital Federal, foi fundada, em Toronto, no dia 9 de Junho de 1904, a The Rio de Janeiro Tramway, Light and Power Co. Ltd., que recebeu autorização para funcionar no Rio de Janeiro em 30 de Maio de $1905 . \quad$ Fonte: http://www.light.com.br/web/institucional/cultura/seculolight/teseculo.asp\#nasc_empres a
} 
As represas criaram um potencial de lazer até então desconhecido na zona Sul, dando margem à especulação imobiliária realizando loteamentos dotados de equipamentos recreativos: chácaras de recreio, clubes de campo, clubes náuticos e balneários passaram a caracterizar os arredores das represas.

A construção da autoestrada Washington Luís em 1928, com 16 km, ligou o Ibirapuera a Interlagos, via Santo Amaro e Socorro e foi, posteriormente, completada com a Avenida Interlagos, impulsionando ainda mais o desenvolvimento das atividades recreativas da região.

Alguns loteamentos residenciais como de padrão médio foram implantados nos anos de 1920, na porção norte da Capela do Socorro, a exemplo da Vila Friburgo.

Outros empreendimentos imobiliários se instalaram na área, no entanto, não evoluíram. Muitas casas construídas para fins residenciais acabaram sendo ocupadas por restaurantes.

Até a década de 40 a Capela do Socorro era ainda pouco ocupada. No entanto, esses anos marcam o início do processo de abertura de loteamentos industriais em Santo Amaro que, pela proximidade, começam a afetar a dinâmica urbana da Capela. Os trabalhadores das empresas de Santo Amaro encontram, em Capela, local mais acessível para morar.

Em um meio essencialmente rural, desenvolveram-se vários povoamentos ao longo de estradas locais ou nos entroncamentos de estradas, à medida que elas passaram a ser percorridas por linhas de ônibus. Entre esses núcleos, destacavam-se pela sua importância, Rio Bonito, situado no entroncamento da então estrada estadual Engenheiro Marsilac com a Estrada do Clube de Campo. Mais ao sul destacava-se a Vila São José, onde já existia um bairro rural de mesmo nome. Estes dois povoados se transformaram em polos em torno dos quais surgiram densos "subúrbios". 
A Cidade Dutra foi outro exemplo de bairro popular surgido na década de 40. Os bairros citados acima haviam se formado num desenvolvimento mais espontâneo da população em torno de entroncamentos de estradas ou de vilas rurais pré-existentes, que passaram a ser servidas por linhas de ônibus. Cidade Dutra, ao contrário, foi planejada e construída pela empresa Auto-Estrada S.A., com financiamento do Instituto de Aposentadorias e Pensões dos Serviços de Transporte (IAPST), com o objetivo de atender a demanda habitacional dos trabalhadores ligados a esse Instituto.

Aquela empresa realizou não só o loteamento, mas a construção das casas. Tratava-se de um grande conjunto residencial (com cerca de 500 unidades inicialmente) caracterizado por extrema homogeneidade no tamanho e estilo das casas, dotado de infraestrutura urbana, como ruas pavimentadas, iluminação pública, água e esgoto, além de um pequeno centro comercial.

$\mathrm{Na}$ época da construção, a Cidade Dutra encontrava-se completamente isolada, mas representou uma experiência pioneira. Logo foram estabelecidas linhas de ônibus para atender ao novo bairro que passou a exercer função polarizadora no desenvolvimento de seus arredores.

Outros bairros continuavam a se formar como resultado de iniciativas imobiliárias, através de loteamento de glebas quase sempre sem preocupações urbanísticas ou outros critérios além da obtenção de lucros. Característica comum a todos foi o fato de que a linha de ônibus surgiu em decorrência do núcleo já loteado e ocupado. Por outro lado, as estradas percorridas pelos ônibus funcionaram como eixos, gerando pequenas aglomerações em torno dos pontos de parada ou no terminal da linha. Nestes locais instalaram-se estabelecimentos comerciais e de serviços, geralmente modestos. 
Os pequenos centros de atividades terciárias ao longo das vias principais foram crescendo à medida que os bairros se adensaram e muitos serviram como polos em torno dos quais surgiram novos bairros. Nas décadas de 50 e 60 o Estado de São Paulo viveu intenso processo de expansão industrial, com importantes alterações no padrão de localização da indústria mais moderna e de maior porte.

Na cidade de São Paulo, este processo teve como um de seus aspectos, a ampliação do parque industrial de Santo Amaro, que se consolida como um dos mais importantes polos de emprego industrial da região metropolitana.

A disponibilidade de terrenos, as facilidades de transporte, particularmente com a construção do sistema de marginais do Rio Pinheiros e a abundância de água e energia, contribuíram para atrair grande número de estabelecimentos industriais dos setores mais modernos da indústria de transformação, que se instalaram ao longo do canal de Jurubatuba.

A implantação industrial teve grande influência em Capela do Socorro, passando a acomodar parte do crescimento urbano da cidade, expandindo-se para a extensa área rural e aproveitando-se da proximidade do centro industrial de Jurubatuba e dos dinâmicos centros de comércio e serviços localizados ao sul e sudoeste da região metropolitana.

Os novos bairros surgidos acompanharam o padrão periférico de expansão urbana que caracterizou o crescimento urbano de São Paulo particularmente nos anos 70 . Os arruamentos penetraram em terrenos de morros vulneráveis à erosão, com altas declividades inadequadas à urbanização, sem infraestrutura urbana, distantes do transporte coletivo, grande número de trabalhadores autoconstruíram suas casas em lotes na maioria das vezes ilegais, comprados através de longos financiamentos. 
O crescimento populacional é um importante indicador das transformações ocorridas na área: de 30.000 habitantes em 1960, a Capela do Socorro passou a 261.230 em 1980 e, projeções baseadas no Censo de 1991 e na Contagem da População em 1996 estimam que a subprefeitura contava com 563.922 habitantes em 2000. Isso representa um incremento populacional de mais de $768 \%$ nos primeiros 20 anos e novo crescimento de $115 \%$ nos últimos 20 anos.

\section{Quadro 3}

Subprefeitura de Capela do Socorro - População / Demografia.

\begin{tabular}{|c|c|c|c|c|c|c|}
\hline Subprefeitura & Distrito & $\begin{array}{c}\text { Área } \\
\left(\mathrm{Km}^{2}\right)\end{array}$ & $\begin{array}{c}\text { População } \\
(1996)\end{array}$ & $\begin{array}{c}\text { População } \\
(2000)\end{array}$ & $\begin{array}{c}\text { População } \\
(2010)\end{array}$ & $\begin{array}{c}\text { Densidade Demográfica } \\
\left(\mathrm{Hab} / \mathrm{km}^{2}\right)\end{array}$ \\
\hline \multirow{3}{*}{ Capela do } & $\begin{array}{c}\text { Cidade } \\
\text { Dutra }\end{array}$ & 29,30 & 181.335 & 191.203 & 196.360 & 6.702 \\
\cline { 2 - 7 } Socorro & Grajaú & 92,00 & 261.878 & 331.837 & 360.787 & 3.922 \\
\cline { 2 - 7 } & Socorro & 12,90 & 40.983 & 39.139 & 37.783 & 2.929 \\
\cline { 2 - 7 } & Total & $\mathbf{1 3 4 , 2 0}$ & $\mathbf{4 8 4 . 1 9 6}$ & $\mathbf{5 6 2 . 1 7 9}$ & $\mathbf{5 9 4 . 9 3 0}$ & $\mathbf{4 . 4 3 3}$ \\
\hline
\end{tabular}

Fonte: http://www.prefeitura.sp.gov.br/cidade/secretarias/subprefeituras/subprefeituras/dados _demograficos/index.php?p=12758, em 27/10/2012.

Adaptado por SOUZA, M.R., 2012.

A partir de 1975, o desenvolvimento urbano foi bastante precarizado, sobretudo, nas áreas de preservação ambiental. Na época a ocupação da Capela do Socorro passou a ser legalmente subordinada à Lei de Proteção dos Mananciais e à legislação de zoneamento industrial. Esta última obteve certo êxito no que se refere às restrições à implantação de novas indústrias na área e ao controle de expansão das existentes. No entanto a legislação relativa aos mananciais foi insuficiente para conter o avanço da ocupação e a degradação ambiental.

A lei dos mananciais estabeleceu baixos limites de densidade para a ocupação do solo e dificultou o licenciamento de empreendimentos na área, mesmo quando adequado às normas legais. Excluídos do mercado imobiliário formal, os preços dos terrenos se tornaram extremamente baixos. A depreciação do valor da terra aliada a outros fatores como uma inadequada política habitacional, a baixa renda dos trabalhadores a 
proximidade de grande concentração de empregos e as dificuldades de fiscalização, e certa conivência, por parte dos órgãos públicos, tiveram como efeito a expansão dos loteamentos clandestinos e de favelas, localizadas em grande parte ao longo dos córregos afluentes das represas.

Nesse documento não encontramos referencial histórico sobre um importante ícone de Capela do Socorro - O Autódromo de Interlagos José Carlos Pace - referencial na localização das escolas pesquisadas, inicialmente, neste trabalho. Inaugurado em 12 de maio de 1940 a história do Autódromo faz parte da própria história de Capela ${ }^{6}$.

Em meados de 2004 os bairros de Jardim Régis (EM. Marina Melander Coutinho), Jardim Primavera (EM. Paulo Setúbal) e Cidade Dutra (EM. Dr. Miguel Vieira Ferreira), entre outros, pertencentes à Capela do Socorro passaram por transformações significativas na infraestrutura viária.

Dessas transformações, a execução do Projeto Básico do Viário de Ligação do Jardim IV Centenário à Av. Miguel Yunes e sua duplicação, conforme ANEXO 1, bem como, a construção das Estações Autódromo, Primavera e Grajaú na ampliação da Linha 9 - Esmeralda da Companhia Paulista de Trens Metropolitanos - CPTM ${ }^{7}$.

No conjunto, tais movimentações urbanas não somente atenderiam às necessidades de transporte de público até o autódromo nos dias de seus eventos, como às necessidades de melhoria no fluxo de trânsito e transportes públicos atingindo a população moradora desse eixo que se estende da Cidade Dutra até Parelheiros, no extremo Sul da cidade de São Paulo.

6 História do Autódromo de Interlagos - Fonte: http://autodromodeinterlagos.com.br/70anos/, Acessado em 03/02/2013.

7 Fonte: História da CPTM

Disponível em: www.cptm.sp.gov.br/e_companhia/CPTM_cronologia_2008_asp; http://www.cptm.sp.gov.br/e_companhia/CPTM_cronologia_2000_09.asp 
Tais Projetos movimentaram imediatamente as populações que ocupavam os terrenos invadidos dessa Companhia que margeavam a extensão dessa antiga ligação ferroviária do Ramal Mairinque-Santos da Estrada de Ferro Sorocabana ${ }^{8}$.

\section{3 - AS TRANSFORMAÇÕES URBANAS E OS REFLEXOS NA VIDA DAS ESCOLAS}

O movimento urbano entre os anos de 2004 a 2008 teve reflexo nas escolas selecionadas para esta pesquisa. As equipes de Gestão dessas unidades escolares diagnosticavam que a diminuição das matrículas dos alunos do ensino regular e também da EJA e do êxodo dos alunos se davam por ocasião das desapropriações, na implantação das obras de melhorias viárias e de transporte no bairro.

As equipes gestoras nestas escolas acreditavam que a maior movimentação no número de transferências de alunos se dava em decorrência do conjunto de obras na infraestrutura local, o que ocasionava também a diminuição de aulas oferecidas aos professores dessas escolas.

A explicação mais simplista e redutora partia então enquanto conformadora e fatalista no processo do desenvolvimento urbano local e, como justificativa, aos números que demonstravam as quedas nas matrículas iniciais nas escolas pesquisadas.

Apesar de certo número de pedidos de transferências por conta dessas desapropriações, o fenômeno ocorria com maior frequência entre os alunos do Ensino Regular, poucos foram os casos de diminuição nas

8 Fonte: Associação Brasileira de Preservação Ferroviária Disponível em: http://www.abpfsp.com.br/ferrovias.htm; http://pt.wikipedia.org/wiki/Marsilac 
matrículas de EJA no período, segundo levantamentos feitos de forma empírica por professores dessas unidades.

Buscavam, até aquele momento, explicação para a repentina baixa nas matrículas em EJA. Acreditavam, no conjunto, ser esta a condicionante no processo das transformações urbanas ocorridas, somada à política de Reorganização de EJA adotada a partir de 2008, pela Secretaria Municipal de Educação, o que constituiu a hipótese inicial desta pesquisa.

Podemos observar essa transformação na Geografia local em dois momentos, conforme as imagens a seguir para desenvolver algumas reflexões:

Imagem 001

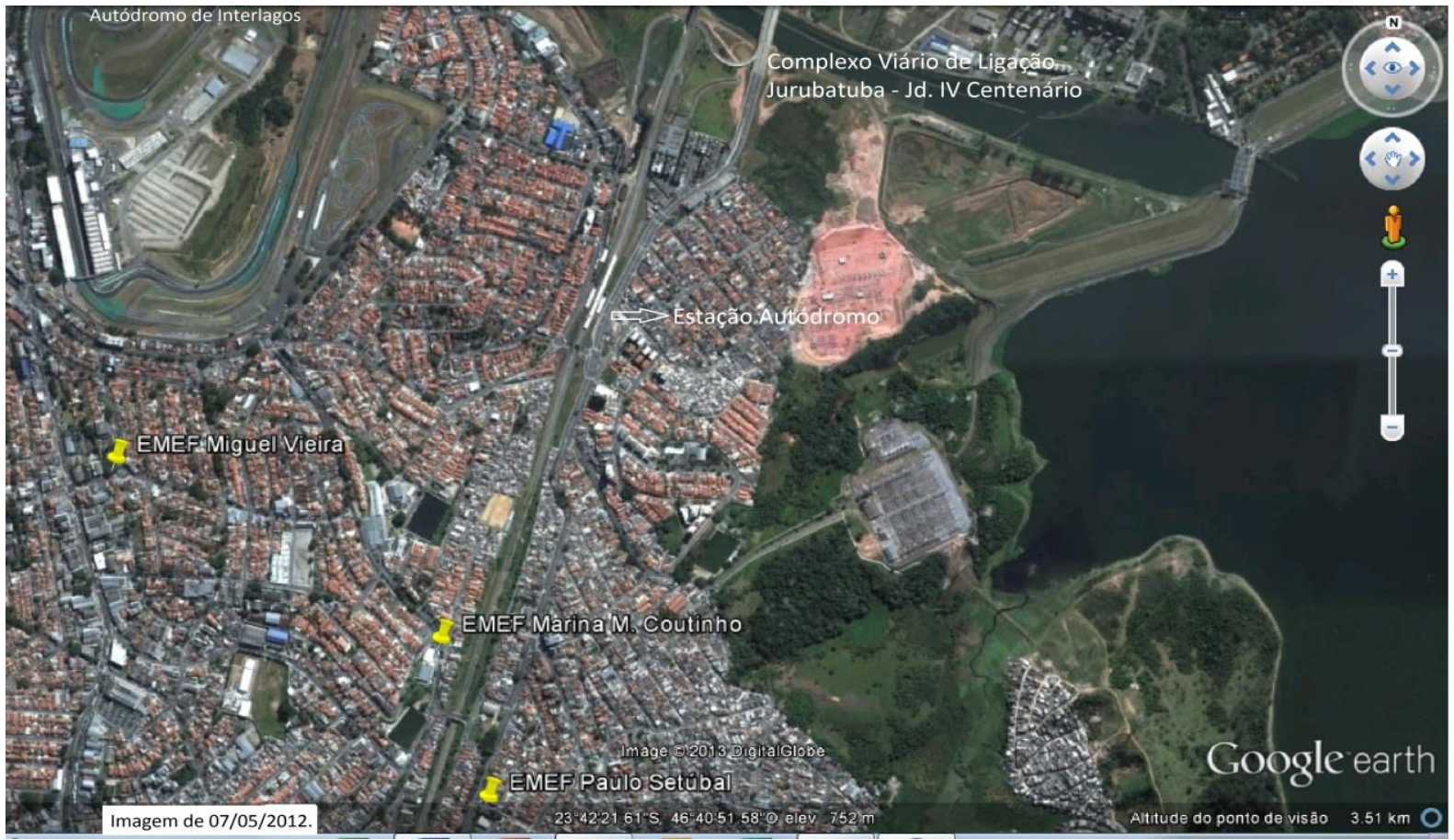

Imagem de Satélite 001, Cidade Dutra em 2012. Em destaque Complexo Viário, Estação Autódromo, EM. Marina M. Coutinho, Paulo Setúbal e Dr. Miguel V. Ferreira. Fonte: Google Earth. Adaptação: SOUZA, M.R., 2012. 


\section{Imagem 002}

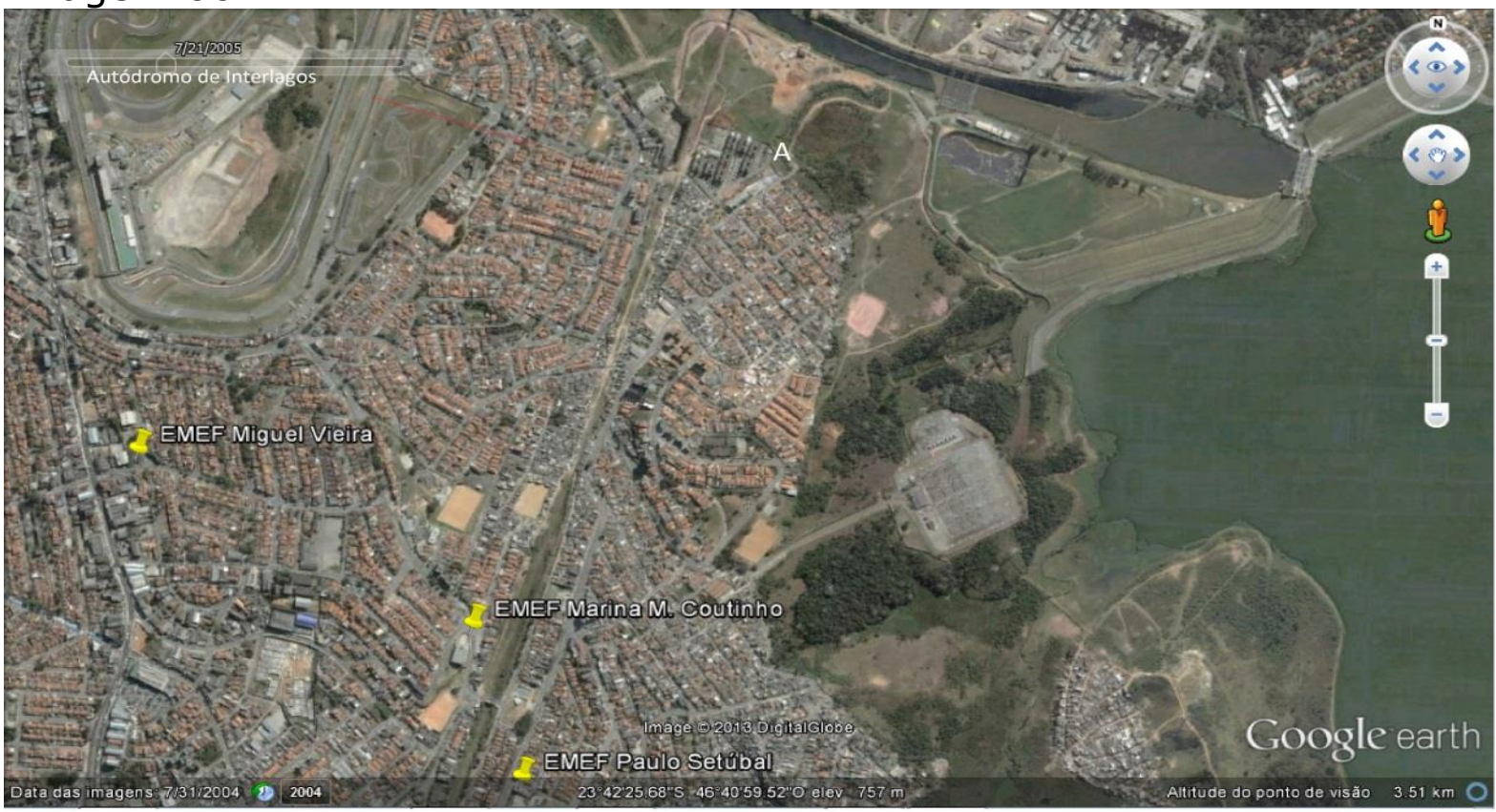

Imagem de Satélite 002, Cidade Dutra em 2004. Em destaque parte do Autódromo de Interlagos, Ponto "A" (Futura Ponte de Ligação) e EMEFs Marina M. Coutinho, Paulo Setúbal e Dr. Miguel V. Ferreira. Fonte: Google Earth. Adaptação: SOUZA, M.R., 2012.

Imagem 003

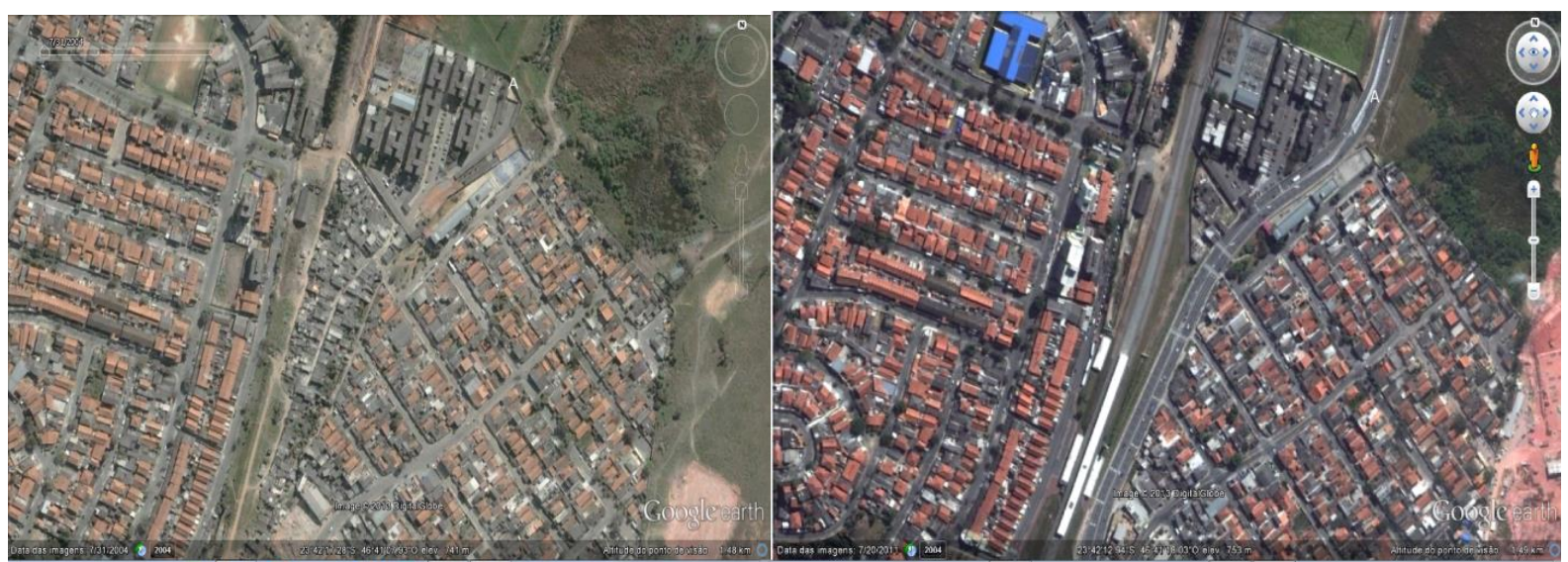

Ampliação de Imagens de Satélite Ponto "A" - Comparativas do Jd. IV Centenário entre os anos de 2004 e 2012 - Em Destaque Complexo Viário de Ligação e Estação Autódromo. Fonte: Google Earth. Adaptação: SOUZA, M.R., 2012.

As áreas desapropriadas, pertencentes à Companhia Paulista de Trens Metropolitanos - CPTM situam-se no mesmo leito deixado pelos trilhos do antigo Ramal Mairinque-Santos da Sorocabana. Nessa linha concentravam-se as favelas do IV Centenário (Ponto " $\mathrm{A}$ " das imagens 2, 3 e 4) e parte da Favela Cheba, que seguindo a linha ferroviária, vai até a 
EM. Marina M. Coutinho. Para considerar que a quedas nas matrículas iniciais da EJA se vinculasse às desapropriações, precisaríamos considerar também tais quedas no Ensino Regular nas três unidades, o que não ocorreu. Na observação entre a Imagem de Satélite 3 e 4 percebemos a proporção da movimentação ocorrida. Os imóveis constituídos nas áreas de não invasão permaneceram e outros investimentos imobiliários adentraram nesse processo a observação da Imagem 3, comparativamente, à Imagem 4, mostra terrenos em 2004 transformados em empreendimentos imobiliários de padrão Médio/Alto. Além de observar a mobilidade dos moradores desapropriados das margens da Linha da Sorocabana para áreas às margens da Represa Billings (Imagem 1).

Nos levantamentos feitos pelos professores em seus diários de classe no pico das desapropriações, entre os anos de 2007/2008 a média de transferências dos alunos regulares, em salas de 35 a 39 alunos, eram no máximo de 6 alunos por sala. Nessa comprovação além do cotidiano vivido, enquanto professor em duas das três escolas pesquisadas, os relatórios oficiais também comprovam que não houve mudança drástica no Ensino Regular, conforme Projeto Pedagógico de uma das unidades o seguinte relato:

A EMEF IV Centenário funcionou em quatro períodos, (três diurnos e um noturno) desde sua fundação, até o final do ano de 2005 . No ano de 2006 passou a funcionar em dois períodos diurnos e um período noturno. Esta redução de turnos trouxe enormes prejuízos pedagógicos para a comunidade escolar e profissionais da educação, uma vez que esta redução de turnos foi feita sem levar em conta as condições humanas, materiais e físicas da escola. Perdemos duas salas ambientes, sala de formação, além de passarmos a trabalhar com $30 \%$ a mais de alunos no mesmo período, dentro do mesmo espaço escolar e com a mesma quantidade de material humano para cuidar. Felizmente, em 2010 estamos em processo de recuperação destes espaços tão importantes para a educação de qualidade. Com a construção da EMEF Santa Maria e a transferência de 350 alunos para esta nova unidade nos facilitou a elaboração de um planejamento de gestão voltado para a recuperação destes espaços perdidos e investimentos em melhoria das condições de trabalhos em aprendizagem escolar (SÃO PAULO, 2011, p. 4-5). 
A EM. Marina Melander Coutinho adotou o nome de EM. IV Centenário até sua inauguração em 2004. A redução de turnos não se deu devido à diminuição do número de alunos. Partiu da Política Educacional de eliminar o chamado "turno da fome" - o período de aulas das $11 \mathrm{~h}$ às 15h que, enquanto estratégia, oferecia vagas nesse horário em muitas escolas municipais paulistanas para suprir as carências dessas vagas em muitas localidades da cidade, entre elas, a zona Sul da cidade.

A essa "mágica" da redução de turnos sem redução de alunos como citada no documento, foi realizada sob muitas perdas, as salas ambientes e de formação de professores da escola foram transformadas em salas de aulas e também construídos mais dois anexos à unidade escolar, como os alunos denominavam "o puxadinho", também com a lotação máxima de alunos por sala. Situação que perdurou de 2006 a 2010, quando da inauguração de outra unidade escolar nas imediações, onde foram transferidos 350 alunos.

Nas salas de EJA essa era uma realidade muito diferente no mesmo período. Apesar de muitos gestores continuarem atribuindo 0 esvaziamento da EJA aos movimentos de transformações urbana locais, outras zonas da cidade que não passaram por processos de transformações semelhantes, de movimento significativo de desapropriações, também se evidenciava essa queda nas matrículas da EJA em grande proporção.

Abandonada a hipótese das desapropriações/movimentos urbanos, enquanto explicação à redução nas matrículas iniciais da EJA nas escolas pesquisadas, passamos a considerá-la como condicionante local nas situações de queda de matrículas iniciais, e não determinante das quedas das matrículas na forma em que se apresentavam em toda a cidade. Fato constatado após as análises de documentos e questionários realizados com alunos e professores dessas unidades escolares mencionadas. 


\section{4 - A EJA NAS ESCOLAS PESQUISADAS INICIALMENTE}

A partir desse item denominaremos as escolas pesquisadas entre EM. "A", EM. "B" e EM. "C". Considerando os aspectos geográficos que caracterizaram o local das escolas pesquisadas, no início do ano de 2012 estavam estruturadas da seguinte forma:

\begin{tabular}{|c|c|c|c|}
\hline \multicolumn{4}{|c|}{$\begin{array}{l}\text { Quadro } 4 \\
\text { Composição das EM.s "A"; "B" e "C" } \\
\text { Alunos do Ensino Regular e EJA - Ano } 2012\end{array}$} \\
\hline Escolas & Alunos & Salas & Educadores \\
\hline EM. "A" & 1072 & 23 & 72 \\
\hline EM. "B" & 1010 & 15 & 71 \\
\hline EM. "C" & 1016 & 16 & 55 \\
\hline
\end{tabular}

Fonte: http://portalsme.prefeitura.sp.gov.br/default.aspx

Organizado por: SOUZA, M.R., 2012.

O que observamos no Quadro 4 é que na relação indireta entre a composição do número de salas com a do número de alunos, nas EMs. "B" e "C" a tendência foi agrupar mais alunos por sala. Dessa relação, não consideradas algumas variáveis, como a dos alunos desistentes, por não ter os registros dos dados no período. As listas ainda não haviam sofrido alterações naquele período, portanto não demonstravam os números próximos aos reais números de alunos em cada unidade escolar.

A evolução das matrículas na EJA dessas unidades entre o ano de 2008 ao ano de 2013 apresentou o seguinte quadro:

\begin{tabular}{|c|c|c|c|c|c|c|}
\hline \multicolumn{7}{|c|}{$\begin{array}{l}\text { Quadro } 5 \\
\text { Evolução das Matrículas Iniciais - EJA } \\
\text { EM.s "A"; "B" e "C" - Período 2008-2013 }\end{array}$} \\
\hline Escolas & \multicolumn{6}{|c|}{ Referência/ ANO } \\
\hline \multirow{4}{*}{$\begin{array}{l}\text { EM. "A" } \\
\text { EM. "B" } \\
\text { EM. "C" }\end{array}$} & 2008 & 2009 & 2010 & 2011 & 2012 & 2013 \\
\hline & 321 & 230 & 343 & 229 & 465 & 362 \\
\hline & 589 & 301 & 307 & 313 & 240 & 229 \\
\hline & 176 & 182 & 200 & 228 & 189 & 209 \\
\hline $\begin{array}{l}\text { Total: } \\
A, B \text { e } C\end{array}$ & 1086 & 713 & 850 & 770 & 894 & 800 \\
\hline$\%$ Evol. & ANO/ANO & $-34,35$ & 19,21 & $-9,41$ & 16,10 & $-10,51$ \\
\hline
\end{tabular}

Fonte: eolgeenciamento.prefeitura.sp.gov.br Organizado por: SOUZA, M.R., 2013. 
Desta tabela observamos que a EM. " $A$ " e " $C$ " foram as que, apesar de algumas oscilações negativas apresentadas em anos específicos, conseguiram manter relativos números de matriculados na EJA. A EM. "B" destaca-se por despencar nos números de matrículas, seguidamente.

O que registramos dessa situação no Quadro 5, indo a campo, foram os resultados das campanhas intensas para matrículas na EJA que as três unidades escolares fazem desde 2009. Dessas campanhas por alunos, registramos dois aspectos que explicaram a presença de baixos índices nas quedas de matrículas locais: Certa mobilidade dos alunos entre essas escolas e os registros dos dados analisados sob as matrículas iniciais de cada ano letivo, dos quais, durante o ano letivo as matrículas sofriam acentuadas baixas, e eram recuperadas entre o término do ano letivo vigente e o início dos anos letivos seguintes, situação produzida a partir das campanhas por alunos. Este procedimento local dificultou o entendimento inicial do problema e deixaria, como sequelas, certo mascaramento à realidade na queda das matrículas locais.

Outro aspecto que dificultou a apreensão desse fenômeno local foi o não fornecimento de alguns dados da EM " $A$ ", como o seu Projeto Pedagógico, fato pelo qual impossibilitou a verificação dos dados ascendentes das matrículas e sua realidade, no período da pesquisa.

Dessa situação, percebemos que muito ainda havia a percorrer, apesar de possuir alguns conhecimentos e vivências nessas unidades escolares.

Após período de amadurecimento às questões iniciais de pesquisa, e da necessidade da busca às nossas inquietações, entre os meses de outubro e dezembro de 2011 elaboramos um questionário aos alunos e outro aos professores.

O questionário aos professores foi aplicado no mesmo período, porém, não trouxemos sua análise nessa pesquisa por dois motivos: 1 . 
Dos vinte e cinco questionários distribuídos nas unidades escolares, somente seis professores devolveram com respostas curtas e incompletas, até o início de 2012. Muitos acabaram removidos para outras unidades escolares e os novos professores não teriam condições de responder às especificidades nas escolas selecionadas. 2. A mudança de foco na pesquisa colaborou para anular a utilização dessa mostra de questões na pesquisa.

Mudamos a metodologia com relação aos professores. Além dos breves relatos informais, anotados em diários de visita às escolas e de toda a rotina de pesquisa, estruturamos uma entrevista com uma experiente professora de EJA de uma das unidades selecionadas, a profa. V., que trataremos em capítulo posterior.

Os questionários aos alunos foram tabulados e analisados. Necessitaram cerca de 80 horas na tarefa de tabulação. As análises seguiram em ritmo do desenvolvimento próprio da pesquisa.

Dos questionários aos alunos: (Os questionários aparecem na integralidade no APÊNDICE " $\mathrm{H}^{\prime}$ ).

Os questionários foram aplicados aos alunos entre os meses de novembro/dezembro de 2011. Divididos em duas partes:

"Sobre você" - com oito questões fechadas, o objetivo foi levantar os perfis do aluno de EJA atendido naquelas unidades escolares;

"Sobre o seu estudo" - com doze questões abertas, objetivava-se identificar/extrair dos alunos através de suas respostas, sistematicamente analisadas, dos seus objetivos em retornar à sala de aula em EJA.

Traremos nessa pré-análise as questões que se relacionam ou indicam os caminhos na elucidação das questões/hipóteses até o momento: Questões B3; B4; B5; B6; B7. 
É importante esclarecer que todas as questões foram tabuladas e pré-analisadas, porém, neste processo final de pesquisa, trabalharemos com as que nos referenciam na continuidade de descoberta do nosso problema, bem como, clarificam nossas categorias de análise, não fechando a possibilidade de recorrer às outras questões, quando das/para suas necessidades de verificação/comprovação.

Questão B3 - Questão introduzida com o objetivo de indiretamente compor como indicador inicial na questão das quedas de matrículas locais. Não somente nos orientou na elaboração do perfil do aluno que regressa aos estudos, mas indica inicialmente, os motivos de seus afastamentos anteriores.

\section{Tabela 4}

Questionário Geral Aplicado aos Alunos "Sobre o seu estudo"

Total de Alunos Pesquisados: 163

EMEFs: A, B e C - NOV/DEZ 2011

\begin{tabular}{lcclr}
\hline $\begin{array}{l}\text { B - Há } \\
\text { estudava? }\end{array}$ & quanto tempo você não & Alunos & \multicolumn{2}{c}{ Por quê? } \\
\hline \\
Menos de 1 ano & 7 & Não resp/ & 53 \\
$1-5$ anos & 32 & Trabalho & 74 \\
$6-10$ anos & 21 & Família/Filhos & 22 \\
$11-20$ anos & 30 & Nunca parou & 4 \\
$21-30$ anos & 16 & Saúde própria & 1 \\
$31-40$ anos & 11 & Falta Interesse & 9 \\
$41-50$ anos & 4 & & 163 \\
Mais de 50 anos & 1 & & \\
Em branco & 8 & & \\
& Não respondeu & 16 & \\
Não sabe & 6 & \\
\hline Nunca parou & 11 & \\
\hline
\end{tabular}

Elaborada por SOUZA, M.R., 2012.

Para analisar a Questão B3 recorremos aos dados primários da questão. Depois de tabulados os dados além de fornececer os dados sobre o tempo de afastamento dos alunos, emergiram: trabalho; família; saúde; interesse. Destas, tratamos dos dados das duas categorias que se 
apresentaram com maior frequência estatística nas respostas (alguns exemplos dos dados brutos, transcrição na íntegra):

\section{Trabalho:}

"Há 19 anos. Trabalhava não tinha tempo" (EMEF B, fl.60);

"Passei 2 anos sem estudar por causa do trabalho" (EMEF B, fl. 56);

"Uns 15 anos motivo de trabalho" (EMEF B, fl.58);

"38 anos porque agora o mercado de trabalho precisa de atualização de estudos para se integrar ao trabalho" (EMEF B, fl. 45);

" 1 mês foi o trabalho atrapalhou bastante" (EMEF B, fl.42);

"20 anos, ouve vários motivos, mais o principal a necessidade de trabalhar (EMEF B, fl. 23. Grifo do Autor);

"Desde 1965, comecei a trabalhar e daí não deu mais" (EMEF B, fl. 63);

"Não estudava a muito tempo, porque onde trabalhava os patrões não deixavam (casa de família) (EMEF B, fl. 15);

"Na verdade nunca quis parar de estudar fui obrigada para quando comecei a trabalhar" (EMEF A, fl. 65);

"45 anos precisava trabalhar" (EMEF C, fl. 08).

Família:

"Há 10 anos porque tive meu filho não tinha como estudar" (EMEF A, fl. 67);

"Uns 10 anos. Por vários motivos, fiquei grávida e por falta de vergonha na cara" (EMEF B, fl. 20);

"Nove anos. Porque fiquei grávida" (EMEF A, fl. 53);

"Não estudava a 53 anos por causa das crianças pequenas" (EMEF A, fl. 48);

"Há 38 anos. Porque eu trabalhava muito para criar meus filhos. E não tive oportunidade" (EMEF A, fl. 38);

"Porque deixei de estudar muito cedo. Porque casei tive 3 filhos dediquei só aos meus filhos e esposo. Depois de todos formados voltei a estudar" (EMEF A, fl. 22). 
Na formação das categorias seguimos os passos de Bardin (1977, p. 104) quando trata da codificação dos dados: O recorte, a enumeração e a classificação e a agregação (escolha das categorias). Para essa tarefa trabalhamos nas unidades de registro, objetivando formar as unidades de significação "a codificar e corresponde ao segmento de conteúdo a considerar como unidade de base, visando a categorização e a contagem frequencial".

Na Questão B3, às respostas dos "Por quês" formulamos um inventário/agrupamento com base sintática - os verbos e adjetivos; léxico - das palavras segundo o seu sentido, com emparelhamento dos sinônimos e dos sentidos próximo; expressivo - por exemplo, categorias que classificam as diversas perturbações da linguagem. O objetivo aqui é, segundo Bardin (1977, p. 118-119), "fornecer por condensação, uma representação simplificada dos dados brutos".

Segue inventário abaixo:

\section{Quadro 6}

INVENTÁRIO - Questionário aplicado aos alunos das EMEF's A, B e C

Período: Nov/Dez 2011

Questão B3: "Há quanto tempo você não estudava? Por quê?

\begin{tabular}{|c|c|}
\hline \multicolumn{2}{|c|}{ Formação das Categorias } \\
\hline TRABALHO & FAMÍLIA \\
\hline $\begin{array}{l}\text { trabalho; serviço; emprego; } \\
\text { por causa dos patrões; } \\
\text { oportunidade (quando cinculada de } \\
\text { alguma forma ao trabalho); } \\
\text { precisava trabalhar; } \\
\text { trabalhando; estava } \\
\text { muito trabalho; minha profissão; } \\
\text { necessidade de trabalhar; } \\
\text { trabalhava muito; trabalhava a noite; }\end{array}$ & $\begin{array}{l}\text { cuidar da casa; } \\
\text { fiquei grávida; gravidez } \\
\text { filhos; cuidar dos filhos } \\
\text { doença em família; } \\
\text { não tinha como deixar minhas filhas; } \\
\text { casei; casei cedo }\end{array}$ \\
\hline $\begin{array}{l}\text { trabalhava para comprar minhas coisas; } \\
\text { o trabalho atrapalhou bastante; falta de } \\
\text { tempo (por questões do trabalho); }\end{array}$ & mãe solteira; \\
\hline $\begin{array}{l}\text { Desistências (Quando em virtude de } \\
\text { trabalho) }\end{array}$ & \\
\hline
\end{tabular}

Fonte: Respostas Tabuladas Questionários Aplicados aos Alunos nas EMEF's A,B e C - Nov/Dez -2011 - Anexo Elaborado por SOUZA, M.R., 2012. 
Seguimos os passos de Bardin (1977, p. 101) no tratamento das demais questões em busca das suas categorizações. Nesta fase de tratamentos dos dados, na busca da validação.

Os resultados brutos são tratados de maneira a serem significativos ("falantes") e válidos. Operações estatísticas simples (percentagens), ou mais complexas (análise fatorial), permitem estabelecer quadros de resultados, diagramas, figuras e modelos, os quais condensam e põem em relevo as informações fornecidas pela análise.

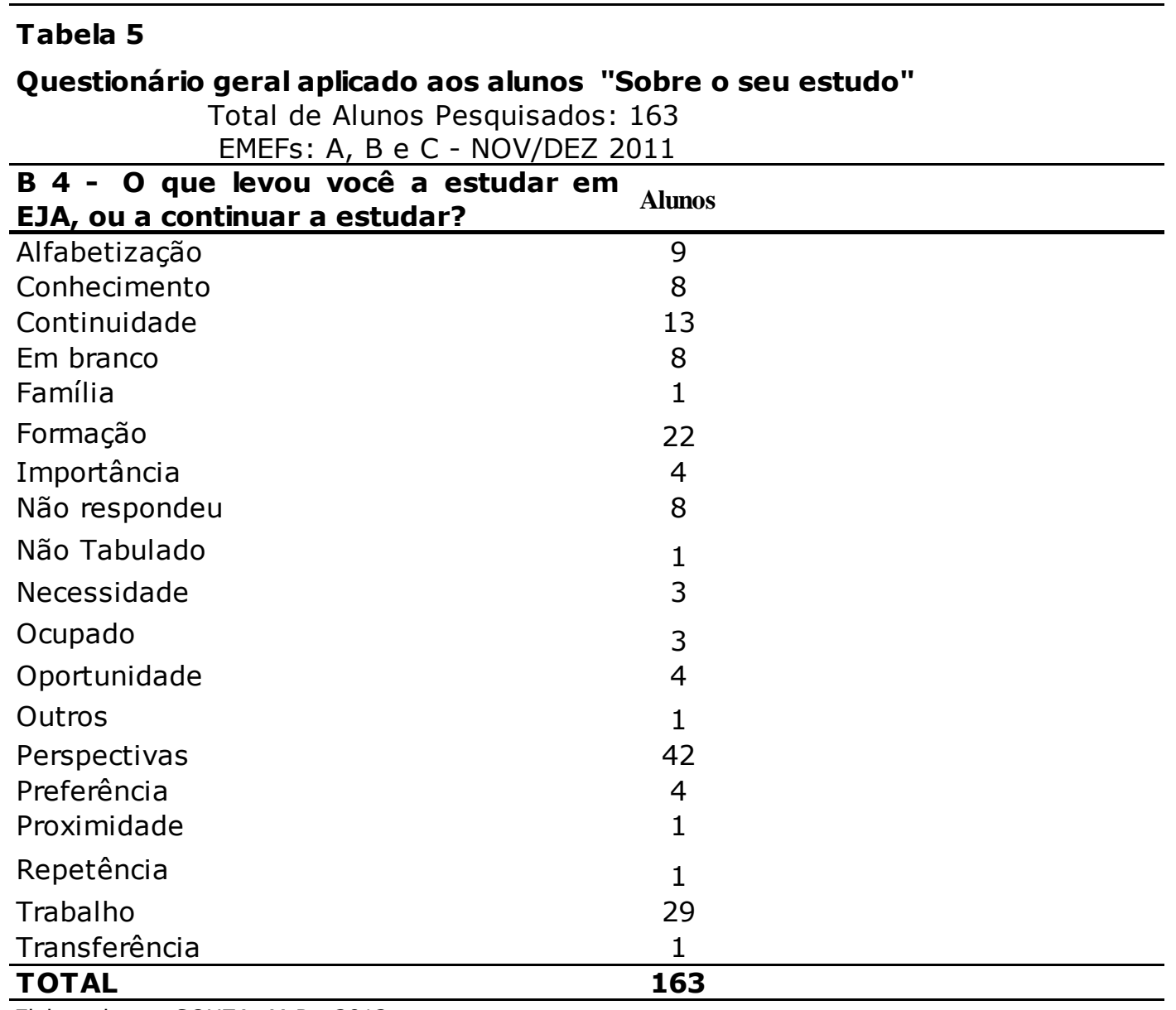

Elaborada por SOUZA, M.R., 2012.

Na Questão B4 seguimos os procedimentos de análise de Bardin (1977), conforme os procedimentos na questão B3. Quando tabulamos pela primeira vez esses dados já havíamos pré-analisado as respostas para a organização das Tabelas. O passo determinante neste momento foi nosso retorno aos dados primários para o inventário da questão. 
Nesta questão, emergiu a centralidade no "trabalho" na vida dos alunos, e o retorno do aluno da EJA à escola enquanto caminho dessa "conquista". O agrupamento das respostas/palavras e a organização posterior do inventário da questão revelaram condicionantes, intencionalidades e representações da escola nesse processo de retorno aos estudos, observados também nas releituras dos dados primários. Os alunos acreditam que o retorno à escola seja um "alavancador" para o trabalho/emprego: "criar oportunidades"; "necessário para o trabalho, ou, para mantê-lo"; "a importância da escola para o trabalho"; "melhoria de perspectivas" (de trabalho), "preciso de um estudo para o trabalho"; entre outras.

A "formação" também emerge nessa questão, mas aqui consideramos para o agrupamento dessa categoria as respostas não vinculadas diretamente às questões do trabalho, mas que intrinsecamente contribuem para o processo. Agrupamos nessa as respostas de manifestação pessoal na busca pela aprendizagem: "aprender mais"; "surgiu a vontade"; "obter conhecimento"; " pra eu poder me aperfeiçoar o estudo e a leitura"; entre outros.

A partir dessa organização nas respostas dos alunos, inferimos o inventário abaixo:

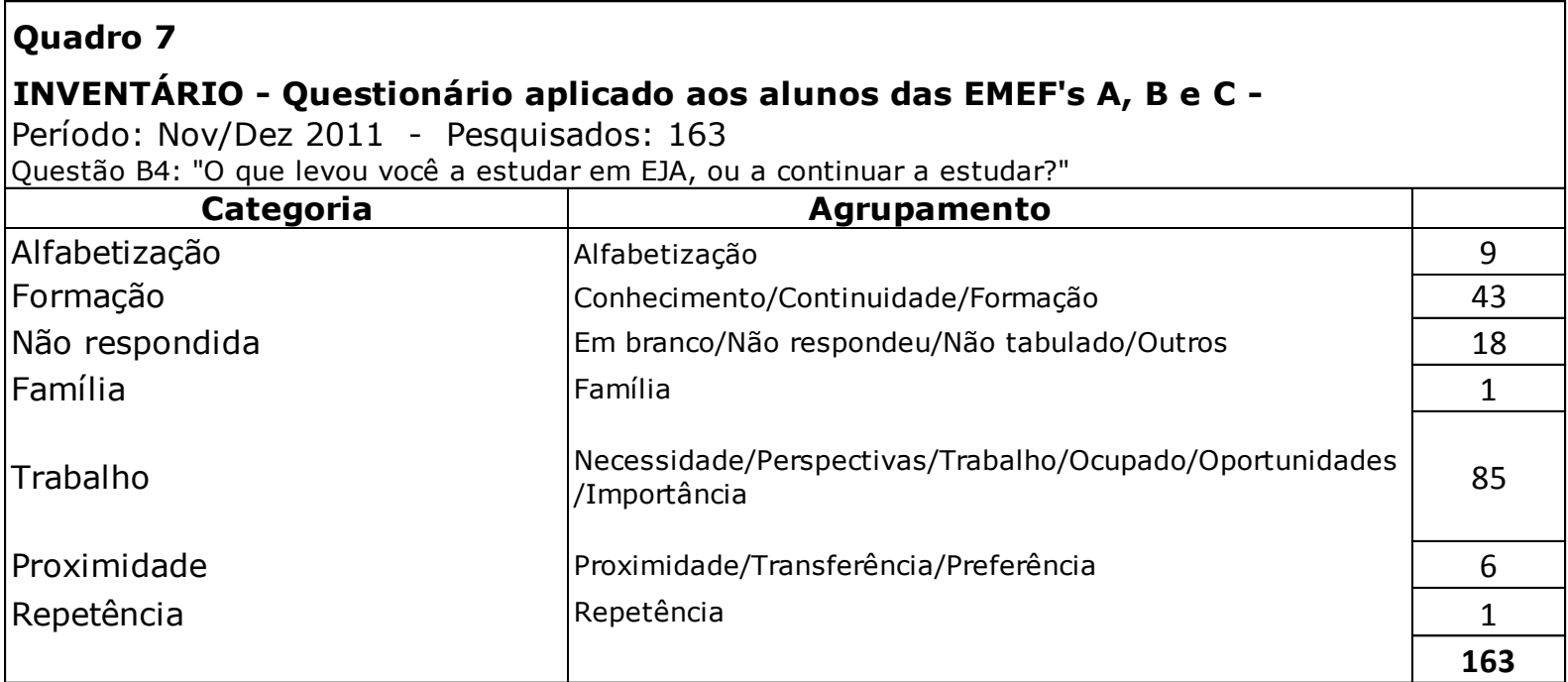

Fonte: Respostas Tabuladas Questionários Aplicados aos Alunos nas EMEF's A,B e C - Nov/Dez -2011 - Anexo Elaborado por SOUZA, M.R., 2012. 
Com $52 \%$ dos pesquisados o "trabalho" aparece com significativa representação na vida dos entrevistados e a escola importante passo nesse processo, alavancadora, o que correspondeu a $26 \%$ das respostas que indicam a "formação".

Desde a Questão B3, para a formação de nosso inventário, seguimos os procedimentos para a categorização de isolamento dos elementos, para depois agrupá-los. Bardin (1977, p. 118-120) revela que a categorização é quotidiana na nossa vida. Desde nossa escola primária aprendemos a recortar, classificar e ordenar, através de exercícios simples. É desse processo classificatório que parte considerável importância em toda e qualquer atividade científica.

Nas tabelas iniciais, quando tabulamos os dados, consideramos nossa "grelha prévia" nosso passo no 1 na análise dessas questões. Quando elaboramos nosso inventário, já amadurecido o pensamento no processo de análise, foi o passo nº 2 .

Os critérios nessa tarefa de organizar os elementos, segundo Bardin (1977, p. 120) foram:

A exclusão mútua - cada elemento não pode existir em mais de uma divisão;

A homogeneidade - Um único princípio de classificação deve governar a sua organização. Num mesmo conjunto, funcionar com um registro e com uma dimensão de análise;

A pertinência - quando está adaptada ao material de análise escolhido, quando pertence ao quadro teórico definido;

A objetividade e a fidelidade - As diferentes partes do mesmo material, ao qual se aplica a mesma grelha categorial, devem ser codificadas da mesma maneira, mesmo quando submetida a várias análises. 
Partimos, então, para a Questão B5, da sua Tabela 08, elaboramos seu inventário nessas bases/critérios:

Tabela 6

Questionário geral aplicado aos alunos "Sobre o seu estudo"

Total de Alunos Pesquisados: 163

EMEFs: A, B e C - NOV/DEZ 2011

\begin{tabular}{lc}
\hline B $\mathbf{5}$ - O que você espera da escola? & Alunos \\
\hline Alfabetização & 3 \\
Conhecimento & 31 \\
Continuidade & 12 \\
Disciplina & 1 \\
Em branco & 9 \\
Formação & 16 \\
Importância & 1 \\
Não respondeu & 9 \\
Oportunidade & 10 \\
Outros & 1 \\
Perspectivas & 32 \\
Qualidade & 36 \\
Sem expectativas & 2 \\
\hline TOTAL & $\mathbf{1 6 3}$ \\
\hline
\end{tabular}

Elaborada por SOUZA, M.R., 2012.

Na Questão B5 seguimos os procedimentos anteriores. Nessa questão as respostas foram mais condensadas, com um grau de variação menor e maior clareza nos registros das fichas (dados primários).

\begin{tabular}{|c|c|c|}
\hline \multicolumn{3}{|c|}{$\begin{array}{l}\text { Quadro } 8 \\
\text { INVENTÁRIO - Questionário aplicado aos alunos das EMEF's A, B e C - } \\
\text { Período: Nov/Dez } 2011 \text { - Pesquisados: } 163 \\
\text { Questão B5: "O que você espera da escola? }\end{array}$} \\
\hline \multirow{2}{*}{\multicolumn{3}{|c|}{\begin{tabular}{|c|} 
Categoria \\
Alfabetizacão
\end{tabular}}} \\
\hline \multirow{6}{*}{$\begin{array}{l}\text { Alfabetização } \\
\text { Formação } \\
\text { Trabalho } \\
\text { Não respondidas } \\
\text { Sem expectativas }\end{array}$} & \multirow{6}{*}{$\begin{array}{l}\text { Alfabetização } \\
\text { Conhecimento; Continuidade;Formação; Qualidade } \\
\text { Perspectivas; Importância, Oportunidade } \\
\text { Em branco; Não respondeu; Outros } \\
\text { Sem expectativas; Disciplina }\end{array}$} & \\
\hline & & 95 \\
\hline & & 43 \\
\hline & & 19 \\
\hline & & 3 \\
\hline & & \\
\hline
\end{tabular}

Fonte: Respostas Tabuladas Questionários Aplicados aos Alunos nas EMEF's A,B e C - Nov/Dez -2011 - Anexo

Elaborado por Márcio R. de Souza, 2012. 
A "formação" na questão aparece com 58\% das expectativas dos alunos. Em segundo lugar com 26\% o "trabalho". Nesta questão - "o que o aluno espera da escola" - tal relaciona-se diretamente às relações intrínsecas aluno/escola, ou seja, a aprendizagem enquanto centralidade, porém, sob a análise do conjunto das respostas, considerando-se os resultados das demais questões deste questionário, inferimos tratar-se de formação em busca ou para o trabalho.

\begin{tabular}{|c|c|}
\hline Tabela 7 & \\
\hline Questionário g & Sobre o seu estudo" \\
\hline & 163 \\
\hline & 011 \\
\hline $\begin{array}{l}\text { B } 6 \text { - O que me } \\
\text { dos estudos? }\end{array}$ & Alunos \\
\hline Alfabetização & 1 \\
\hline Amigos & 6 \\
\hline Autonomia & 1 \\
\hline Conhecimento & 22 \\
\hline Disciplina & 1 \\
\hline Em branco & 9 \\
\hline Família & 6 \\
\hline Formação & 33 \\
\hline Não respondeu & 1 \\
\hline Não sabe & 1 \\
\hline Oportunidade & 3 \\
\hline Os professores & 2 \\
\hline Perspectivas & 39 \\
\hline Proximidade & 1 \\
\hline Qualidade & 4 \\
\hline Trabalho & 33 \\
\hline TOTAL & 163 \\
\hline
\end{tabular}

Da Questão B6, consideradas as respostas dos dados primários, no conjunto, inferimos que conhecimento, formação e perspectivas emergem enquanto prerrogativas necessárias ao ingresso/manutenção para o trabalho, segundo estes alunos. Também emergem no próximo quadro de respostas. 


\begin{tabular}{|c|c|c|}
\hline \multicolumn{3}{|c|}{$\begin{array}{l}\text { Quadro } 9 \\
\text { INVENTÁRIO - Questionário aplicado aos alunos das EMEF's A, B e C - } \\
\text { Período: Nov/Dez } 2011 \text { - Pesquisados: } 163 \\
\text { Questão B6: "O que mais o motiva a continuidade dos estudos?" }\end{array}$} \\
\hline Categoria & Agrupamento & \\
\hline \multirow{10}{*}{$\begin{array}{l}\text { Alfabetização } \\
\text { Não respondeu } \\
\text { pessoas } \\
\text { Autonomia } \\
\text { Formação } \\
\text { Família } \\
\text { Trabalho } \\
\text { Disciplina } \\
\text { Proximidade }\end{array}$} & \multirow{10}{*}{$\begin{array}{l}\text { Alfabetização } \\
\text { Não respondeu; não sabe; em branco } \\
\text { Amigos, professores } \\
\text { Autonomia } \\
\text { Formação; conhecimento; qualidade; } \\
\text { Família } \\
\text { Trabalho; perspectivas; oportunidade } \\
\text { Disciplina } \\
\text { Proximidade }\end{array}$} & 1 \\
\hline & & 11 \\
\hline & & 8 \\
\hline & & 1 \\
\hline & & 59 \\
\hline & & 6 \\
\hline & & 75 \\
\hline & & 1 \\
\hline & & 1 \\
\hline & & 163 \\
\hline
\end{tabular}

Fonte: Respostas Tabuladas Questionários Aplicados aos Alunos nas EMEF's A,B e C - Nov/Dez -2011 - Anexo

Elaborado por SOUZA, M.R., 2012.

Nesta questão $46 \%$ dos entrevistados mostram como motivação a continuidade dos estudos, mas como possibilidade de ingresso/manutenção ao mercado de trabalho. E 36\% dos entrevistados acreditam a boa "formação" como mais uma garantia desse caminho.

\begin{tabular}{|c|c|}
\hline $\begin{array}{l}\text { Tabela } 8 \\
\text { Questionário }\end{array}$ & $\begin{array}{l}\text { obre o seu estudo" } \\
163 \\
011\end{array}$ \\
\hline $\begin{array}{r}\text { B } 7 \text { - O que } \\
\text { dos estudos? }\end{array}$ & Alunos \\
\hline Falta de vaga & 1 \\
\hline Desempenho & 1 \\
\hline Outros & 1 \\
\hline Motivação & 6 \\
\hline Indisciplina & 2 \\
\hline Ausência & 1 \\
\hline Aula vaga & 3 \\
\hline Desemprego & 1 \\
\hline Distância & 4 \\
\hline Doença & 21 \\
\hline Insatisfação & 1 \\
\hline Nada & 55 \\
\hline Não aprender & 3 \\
\hline Não sabe & 7 \\
\hline Família & 4 \\
\hline Imprevistos & 8 \\
\hline Retenção & 6 \\
\hline Trabalho & 22 \\
\hline Não respondeu & 3 \\
\hline Em branco & 13 \\
\hline TOTAL & 163 \\
\hline
\end{tabular}

Como questão central aplicada neste questionário, no período do trabalho de campo, esta foi a tentativa de estabelecer uma hipótese provisória para o entendimento nas quedas das matrículas na EJA no Município de São Paulo. Considerada a objetividade da questão, percebemos certo constrangimento dos alunos ao respondê-la. 
Dos trabalhos realizados com EJA, percebemos que falar em abandono da escola em salas de EJA, para significativa parte dos alunos, representaria o "retrocesso" na vida e estagnação profissional. Seria o abandono do "sonho". Representaria abandonar a perspectiva "da melhoria de vida", esta, atrelada às perspectivas de melhoria do trabalho e consequentes salários, objetivos explícitos e implícitos que tanto emergem nas respostas primárias das questões aplicadas.

Das condições de precariedade social, percebemos não serem raros os relatos em que o aluno culpa-se ou acusa-se pela sua própria defasagem nos estudos e às limitações impostas, nestas condições, às suas próprias vidas.

Na Questão B3 - Há quanto tempo você não estudava? Por quê? pudemos extrair alguns destes exemplos de "autoculpa" ou "autoacusações": "não tinha incentivo"; "falta de vontade"; "tive meu filho, não tinha como estudar"; "por descuido mesmo; falta de iniciativa"; "casei muito cedo"; "Por vários motivos, fiquei grávida e por falta de vergonha na cara".

Nesse caminho, organizamos o inventário da Questão B7 abaixo:

\begin{tabular}{|c|c|c|}
\hline $\begin{array}{l}\text { Quadro } 10 \\
\text { INVENTÁRIO - Quest } \\
\text { Período: Nov/Dez } 2011 \\
\text { Questão B7: "O que pode le }\end{array}$ & $\begin{array}{l}\text { licado aos alunos das EMEF's A, B e C } \\
\text { sados: } 163 \\
\text { lesistir dos estudos? }\end{array}$ & \\
\hline Categoria & Agrupamento & \\
\hline Desorganização (escolar) & aula vaga; indisciplina; falta de vaga; ausências; & 7 \\
\hline Desempenho & Desempenho; motivação; Insatisfação; Não aprender; Retenção & 17 \\
\hline Não sabe & Não sabe; Não respondeu; Em branco; Outros & 24 \\
\hline Distância & Distância & 4 \\
\hline Família & Família & 4 \\
\hline Doença & Doença; imprevistos & 29 \\
\hline Trabalho & Trabalho; desemprego & 23 \\
\hline Nada & Nada & 55 \\
\hline & & 163 \\
\hline
\end{tabular}

Fonte: Respostas Tabuladas Questionários Aplicados aos Alunos nas EMEF's A,B e C - Nov/Dez -2011 - Anexo Elaborado por SOUZA, M.R., 2012. 
Para os alunos assumirem tal possibilidade de desistência, naquele momento da nossa entrevista e no contexto em que estavam inseridos, em ambiente escolar, representaria autodefesa. Nesse sentido, emergiu um nível elevado de "negação" nos resultados da Questão B7.

Até esse ponto da nossa pré-análise tentávamos formular uma hipótese que, como diretriz, se sustentasse ou se infirmasse ao longo do processo na pesquisa.

Na análise desse inventário algo sinalizava ainda a falta de diretriz para a continuidade da pesquisa. Diferentemente das outras questões, esta pareceu ter fragmentado de certa maneira a resposta. Nesse momento surgiu obscurecimento diante da diretriz a seguir. Perdemos alguns passos no caminho e retomá-los necessitaria um amadurecimento, no pensamento e no método. Pois, qual era o real condicionante ou determinante nas quedas das matrículas iniciais na EJA?

Análise de conteúdo firma-se neste estágio da pesquisa, enquanto "desejo de rigor e necessidade de descobrir, de adivinhar, de ir além das aparências", nesse sentido:

[...] Metodologicamente, confrontam-se ou complementam-se duas orientações: a verificação prudente ou a interpretação brilhante. $[\ldots]$ seja qual for a natureza do seu suporte $[. .$.$] possui$ duas funções, que na prática podem ou não dissociar-se: - uma função heurística:[...] enriquece a tentativa exploratória, aumenta a propensão à descoberta [...] É a análise de conteúdo "para ver o que dá". Uma função de "administração de prova". Hipóteses sob questões ou afirmações provisórias servindo de diretrizes [...] para serem verificadas no sentido de uma confirmação ou de uma infirmação. É a análise de conteúdo "para servir de prova" (BARDIN, 1977, p. 29-30).

Dos 163 entrevistados, predominaram em suas respostas: 10 lugar $38 \%$ deles afirmam "NADA" poderia ser considerado, ou impedi-los da continuidade dos estudos ou como o motivo de sua desistência aos estudos. A seguir, em 20 lugar - $18 \%$ dos alunos da EJA nas escolas pesquisadas afirmam desistir em caso de "doenças" ou "imprevistos". Em 
30 lugar - $15 \%$ não sabem, não responderam ou deixaram em branco a questão. Sobre o trabalho como condicionante da desistência, responderam apenas $14 \%$, em 40 lugar. Apenas $10 \%$ dos alunos afirmaram desistir do seu curso por desempenho escolar insatisfatório. Menos $4 \%$ desistiriam por questões de desorganização escolar e por último, $2 \%$ ou menos desistiriam dos seus estudos por questões de família ou distâncias.

Grande parte das respostas nessa categoria, "NADA", foram representadas por esse único pronome indefinido, que na língua portuguesa pode significar': nenhuma coisa; de modo algum; a não existência.

Recorremos às nossas fichas primárias de dados para uma releitura das respostas, na busca da compreensão das representações ou condicionantes de "NADA" que os alunos emitiram nas suas respostas: "por nada"; "Nunca eu vou desistir porque eu quero um bom emprego"; "não sei, no momento nada"; "Nada!"; "Nessa fase da minha vida nada"; "Nada mais faz com que eu desista; "Por enquanto nada me leva a desistir"; Hoje eu estou determinada, acredito que nada me faça desistir"; "Espero que nada venha a contribui para isso acontecer"; "Acho que nesse momento nada"; "Nada, pois a escola em que eu estudo, está sempre procurando me ensinar através de cinema, oficinas e muito diálogo Obrigada a todos".

Procuramos entender as representações do "NADA" na questão. Dessa proposição inferimos sobre as representações da "negação" e da "contradição" conceitos/categorias que trataremos em outro capítulo, seguindo o encadeamento de nosso pensamento/método. Desse novo

${ }^{9}$ FERREIRA, A.B.H. Minidicionário da Língua Portuguesa. 2a Ed. 3a Impressão. Rio de Janeiro: Nova Fronteira, 1989. 
indício que aponta a Questão B7 encontramos algumas condicionais para o "NADA".

Sob as condicionais: "no momento"; "por enquanto"; "nessa fase"; "hoje"; "acredito"; "espero"; "acho", que circundaram em muitas respostas da Questão B7, reforçaram os indícios por um determinante, oculto nas palavras, que poderia alterar a qualquer momento a situação de aluno ativo, para desistente. Quando agrupamos o conjunto das categorias das Questões B3, B4, B5, B6 e B7 obtivemos o seguinte quadro:

\begin{tabular}{|c|c|c|c|c|c|c|c|c|c|}
\hline \multicolumn{10}{|c|}{$\begin{array}{l}\text { Quadro } 11 \\
\text { INVENTÁRIO DAS CATEGORIAS - QUESTÕES B3 A B7 } \\
\text { BASE: - Questionários aplicados aos Alunos - EMEF's A, B e C. } \\
\text { Pesquisados: } 163 \text { - Nov/Dez } 2011\end{array}$} \\
\hline \multicolumn{10}{|c|}{ Questões } \\
\hline B3/Cat. & & B4/Cat. & & B5/Cat. & & B6/Cat. & & B7/Cat. & \\
\hline Família/Filhos & 22 & Alfabetização & 9 & Alfabetização & 3 & Alfabetização & 1 & Desempenho & 17 \\
\hline Interesse & 9 & Família & 1 & Formação & 95 & Autonmia & 1 & Desorganização & 7 \\
\hline Não respondeu & 53 & Formação & 43 & Não respondeu & 19 & Disciplina & 1 & Distância & 4 \\
\hline Nunca parou & 4 & Não respondeu & 18 & Sem expectativas & 3 & Família & 6 & Doença & 29 \\
\hline Saúde & 1 & Proximidade & 6 & Trabalho & 43 & Formação & 59 & Família & 4 \\
\hline \multirow[t]{4}{*}{ Trabalho } & 74 & Repetência & 1 & & & Não respondeu & 11 & Nada & 55 \\
\hline & & Trabalho & 85 & & & Pessoas & 8 & Não sabe & 24 \\
\hline & & & & & & Proximidade & 1 & Trabalho & 23 \\
\hline & & & & & & Trabalho & 75 & & \\
\hline Totais & 163 & & 163 & & 163 & & 163 & & 163 \\
\hline
\end{tabular}

Neste momento da pesquisa descartamos, definitivamente, algumas hipóteses que circulavam provisoriamente sustentadas desde o início deste trabalho, como a das transformações urbanas locais e da Reorganização da EJA promovida pela SME em 2008. Nossos estudos apontaram para a busca uma determinante que sustentasse os resultados até o momento apresentados e, que das análises pudéssemos qualitativamente, fundamentar nosso pensamento sobre os processos de quedas nas matrículas da EJA no município de São Paulo.

Encontramos nos resultados dos questionários, condicionantes em níveis a serem considerados, como, a distância entre trabalho/escola/casa; desempenho escolar insatisfatório; a desorganização no atendimento ao aluno de EJA, a formação do professor; 
e mesmo as políticas públicas educacionais para EJA, entre outros, mas que não explicava de maneira satisfatória a queda nas matrículas da EJA apresentada não somente no quadro paulistano, mas nacionalmente.

Dos resultados das análises dos questionários uma nova hipótese emergiu enquanto categoria: o trabalho. Embora com oscilações em alguns níveis, essa categoria se apresenta quase na totalidade das preocupações dos alunos. Apresenta-se em todas as respostas. Seguindo essa indicação ampliamos novamente a investigação.

Considerados os levantamentos da pesquisa, a nossa busca neste momento é afirmar ou infirmar uma determinante ou as condicionantes nas quedas das matrículas iniciais na EJA no Município de São Paulo, quiçá, apontar tal determinante em nível nacional, considerando os levantamentos estatísticos realizados até aqui.

Precisamos aprofundar um pouco mais a busca pela hipótese que explique ou elucide a questão da pesquisa, e nessa tarefa, apropriandonos da Geografia. Percebemos no problema central da pesquisa seu vínculo com a dinâmica da produção e reprodução dessa vida na metrópole, o qual possa indicar também um problema da cidade, do estado ou do país, socialmente imposto, mas ocultado sob muitos aspectos, dos quais, tentamos desvelar neste trabalho. Para tanto, buscar reflexão na própria Geografia. Pensamento que corroboramos em Damiani (1999a):

$\mathrm{Na}$ Geografia, as mudanças históricas concretas, com o acirramento das contradições, desembocam em grandes rupturas técnicas, metodológicas e temáticas. Abordagens que, de forma subjacente, fundamentam-se no espaço geométrico, considerado como continente de relações, passam a reflexões que privilegiam o espaço social, produzido e reproduzido socialmente, considerado produto e produtor das relações sociais. Mais do que nunca, a Geografia afirma-se como uma ciência social (DAMIANI, 1999a, p. 51). 
Retomando a busca, recorremos aos gráficos sobre os índices de matrículas em EJA em todo o Brasil, em todos os âmbitos, sejam Municipais, Estaduais ou Federais. A frequência da queda de matrículas na EJA se eleva independentemente dos fatores que inicialmente tínhamos como os fatores mais "visíveis". Nesse sentido, alguns equívocos do nosso pensamento inicial, e do senso comum que pairava em certos aspectos, diluíram-se.

Outro aspecto que se apresenta aqui foram as frequencias nos períodos de quedas nas matrículas em termos nacionais, predominantemente, entre os anos de 2007-2008.

Uma variável ainda não havia sido mensurada até dezembro de 2012 e consideramos fundamental para a continuidade da investigação, diante de tudo que emergia: a entrevista com um representante da Secretaria Municipal de Educação, na Diretoria Regional de Educação.

No dia 23 de dezembro de 2012 em entrevista com o Professor R., durante a gravação, seu depoimento sinalizou uma diretriz consistente em direção à nossa busca. Fomos à transcrição da entrevista, momento que intensificou os sentidos da pesquisa e clarificou nossa hipótese para a quedas das matrículas.

A entrevista foi enriquecedora, sob muitos aspectos, mas a partir de uma significativa questão a determinante emergiu lentamente, no aprofundamento e especificidade das questões:

\section{- Qual foi o projeto mais impactante que você participou nesse percurso com relação à organização dos cursos de EJA? Explique.}

\footnotetext{
"Eu não sei se tem um projeto específico viu o Márcio porque eu acho que na verdade o que ficou é que a EJA está sempre sendo discutida, mas parece que ela tá sempre nadando em areia movediça. Então eu acho o que ficou de qualquer projeto ou percurso, vamos falar em percurso, que eu tenha participado é a necessidade muito grande se rever a fundo: Qual é a função da EJA não só em São Paulo, mas no Brasil? O que significa enquanto
} 
nação, de fato, enfrentar o problema do analfabetismo funcional nesse público que é formado de tanto aquele jovem que acaba sendo expulso do ensino fundamental e ainda com pouca idade quer acelerar os estudos você tem, por exemplo, os alunos de dezoito anos, dezessete e as vezes de dezesseis anos querendo fazer EJA, ele tá fora da idade/série mas também não é um aluno com tanta idade e justificaria ele acelerar o estudo" (Prof. R., Dez., 2012).

Nossa busca por uma determinante/condicionante do problema, objetivamente, busca evitar um estudo circular sobre o que se discute e que o entrevistado resume: "acho que na verdade o que ficou é que a EJA está sempre sendo discutida, mas parece que ela tá sempre nadando em areia movediça". É claro, consideramos a complexidade que se desenvolve nessas relações, quando sociais, revela-se em hipercomplexidade, termo extraído da reflexão Lefebvreana sobre a fragmentação do espaço e dos seus desdobramentos. Nesse caminho, flexionamos o princípio da interpenetração e da superposição dos espaços sociais de Lefebvre:

[...] cada fragmento de espaço retido pela análise não esconde uma relação social, mas uma multiplicidade que a análise revela. [...] A hipótese inicial se alarga, se amplia. [...] Um conjunto de novas questões [uma "problemática"] [...] desloca os antigos problemas, os substitui e se superpõe a eles sem por isso os abolir (LEFEBVRE, 2006, p.28).

A complexidade que a análise revela quando tratamos dos espaços sociais faz-nos observar, permanentemente, sobre o "nadar em areia movediça" quando tratamos sobre os problemas da EJA, entendemos relação direta a esse princípio da interpenetração e superposição dos espaços sociais e que resgataremos adiante, quando trataremos as categorias aqui levantadas nesta seção.

É importante observar que no trecho citado em Lefebvre, quanto ao deslocamento dos antigos problemas, quando observados sob os problemas da EJA, percebemos a similaridade da colocação, tratando-se das políticas educacionais que temos nos apropriado no desenvolvimento dessa pesquisa. 
- Que contribuições/ideias/sugestões você proporia para a EJA na cidade de São Paulo e na Capela do Socorro?

"É isso mesmo, parar e pensar o que é a EJA? Atende a quem? O que significa você ter/fazer um trabalho de inserção desse público na cultura letrada?" (Prof. R., Dez., 2012).

$\mathrm{O}$ entrevistado coloca algo basilar: $\mathrm{O}$ que é a $\mathrm{EJA}$, atende a quem? A questão então nos remete ao entendimento da apropriação desse espaço denominado EJA. Sobre a tentativa de entendimento dessa apropriação, Lefebvre (2006, p. 129), nos adverte que "ainda que não seja sempre fácil dizer em que e como, por quem e para quem, eles foram apropriados [...] Somente o estudo crítico do espaço permite elucidar o conceito". Questão que retornaremos adiante.

- Dentro de tudo isso que você tá colocando aí, disso tudo que a gente tá falando, você com certeza ouviu falar de EJA de outras partes de São Paulo. Você foi a outras reuniões onde encontrou representantes de outros EJAS de outras regiões, como vocês devem ter discutido desse período, cada um o seu problema na sua região, mas da nossa região que mais de especificidade você pôde observar que você não ache em Pirituba, por exemplo, tem alguma coisa muito diferente da sua área, em Capela que aconteça isso, mas em Pirituba não vai acontecer, tem alguma especificidade aqui na nossa região na EJA diferente das outras EJAS de São Paulo?

"Olha de uma maneira geral penso que não. Porque um grande
problema que a gente tem em EJA é a questão do aluno
trabalhador, [...] o aluno de EJA volta para a escola com uma série
de expectativas, mas ele já tem toda uma vida estruturada e a
escola não ocupa uma centralidade para ele. Tem uma expectativa
muito grande com relação à escola, mas a centralidade é o
trabalho é a subsistência então, por exemplo, no primeiro
empecilho se ele não tiver condição de que as expectativas que ele
tem estão sendo supridas/idealizadas/contempladas ele desiste. Eu
percebo isso tanto aqui quanto, por exemplo, sou coordenador de
um curso de EJA numa escola particular com o mesmo público, a
escola tem todos os recursos, lá não existe dispensa de aula por 
motivo nenhum. O aluno vai sabendo que vai ter aula da primeira à última aula" (Prof. R., Dez., 2012).

Nosso entrevistado na questão contribuiu na questão central da pesquisa, na afirmação da diretriz que deveríamos seguir e que a todo o momento se pronunciou em outros momentos de entrevistas informais e dos questionários aplicados em nossas pesquisas de campo: a centralidade do trabalho na vida dos alunos, que emerge sobre todas as outras prioridades.

Em nossos inventários, o trabalho prevalece enquanto a determinante dos alunos em suas desistências ou não retorno à escola.

Mais uma vez recorremos às bases primárias de nossos dados, a fichas. Reportamo-nos às respostas de duas questões: B2 - Qual o motivo da sua vinda para a EJA nesta escola? B3 - Há quanto tempo você não estudava? Por quê? E B7 - O que pode levar você a desistir dos estudos?: - "terminar rápido, quero conseguir um emprego melhor, [...] estava trabalhando, não tinha tempo"; "preciso terminar meus estudos, [...] mais o principal a necessidade de trabalhar"; "trabalhar para comprar as minhas próprias coisas"; "se estiver trabalhando e ficar muito cansado"; "desistir dos estudos só se tiver que trabalhar em horários diferentes"; "para trabalhar"; "o trabalho"; "se ficar muito longe do meu trabalho"; "uma boa proposta de emprego; "o serviço às vezes difícil e cansativo", entre outras respostas que levaram a um mesmo determinante da desistência aos estudos: o trabalho. Conforme prosseguimos com a entrevista com o Prof. R. a nossa hipótese nessa direção afirmava-se. Vejamos as próximas questões, enquanto nossa administração de provas.

\section{- Tem professor bem formado professor que atende bem as expectativas dele? Você percebe que ocorre a mesma questão?}

"Sim, tem professor formado. A mesma questão, por exemplo, se a mãezinha ficou doente vai parar de estudar porque vai precisar cuidar da mãe, porque é diferente, o aluno não é como do regular que se a mãe fica doente quem vai cuidar, enfim, a criança... o adulto não, porque se a mãe já tem 60, 70 anos mora numa outra cidade, ele tranca a matrícula viaja pra cuidar da mãe. Cuidou da 
mãe, se a mãe sarou ou a mãe morreu volta e volta a estudar. Então é engraçada essa coisa... Eles gostam da escola, eles querem escola, mas não é a centralidade no sentido de que ele precise da escola para organizar a sua vida. A vida dele já tá de alguma forma organizada, isso eu percebo na rede pública, na rede estadual e a gente conversa com outros/outras regiões e se percebe a mesma coisa, a desistência, a evasão... Talvez, o que tenha de diferença seja nas regiões centrais, tem alguma diferença, talvez chame um público que já tenha a sua vida financeira ou de trabalho mais organizada, não dependa tanto de trabalhos em subempregos etc., mas de uma maneira geral o adulto que procura a EJA, principalmente nas regiões periféricas, é aquele adulto que tá sem emprego ou tá subempregado ou está desempregado hoje. Arranjou um emprego numa outra cidade ele vai com certeza e não se preocupa muito, assim: "ah... eu vou pegar a minha transferência eu vou levar que vou estudar lá" Não! Ele vai organizar primeiro a vida de trabalho dele lá se der para estudar ele vai estudar se não der ele pára de estudar nesse tempo e quando ele volta, ele procura de novo a vaga" (Prof. R., Dez., 2012).

$\mathrm{Na}$ questão emergem algumas condicionantes como as questões pessoais e de família, bem como, da formação do professor e das condições materiais de atendimento aos alunos nas escolas. A escola tratada aqui pelo prof. R. é referência educacional privada na zona Sul de São Paulo. Os professores tem remuneração acima da média e possuem formação contínua e específica para docência em EJA. Procuramos saber se os cursos da EJA nessa escola privada possuía cobrança de mensalidade. O prof. R. informou por e-mail, posteriormente à nossa entrevista que, durante todo o ciclo de alfabetização, ciclo I, o curso de EJA é totalmente gratuito. No ciclo II paga-se uma mensalidade simbólica.

\section{- Como você avalia o esvaziamento das salas de EJA na Capela?}

"Eu tenho comparado porque estou na região Sul na escola particular e aparentemente os motivos são os mesmos, o trabalho, é o cansaço..." (Prof. R., Dez., 2012).

\section{[...] Você acredita que nós tenhamos demanda e ela está, por algum motivo, reprimida?}

"SIM" (Prof. R., Dez., 2012). 


\section{- Está reprimida por fatores que extrapolam a nossa instância enquanto instituição seria isso? Essa é a questão que eu gostaria de perguntar, quer dizer, Tem evasão? A questão é, todos se formaram então, não existe mais adulto pra se formar? Mudaram de cidade? Ou por vários motivos acabam?}

"Não. São Paulo tem um número grande de pessoas (sem formação) daí que eu falo para você quanto à política pública que partisse de uma força tarefa do Estado das instâncias governamentais que se pensasse de fato. [...] o atendimento a essa demanda... flexibilidade... as questões sazonais... o trabalho. O trabalho ocupa uma centralidade é lógico. Tenho filhos para sustentar, estou estudando, estou desempregado se eu arrumar emprego numa outra cidade eu vou deixar o meu estudo, então, como atender esse aluno também? Se há um projeto de atendimento para este adulto que não pôde estudar na idade certa eu não posso simplesmente trazê-lo, inseri-lo no sistema e ele puxar um percurso que foi interrompido lá traz da mesma maneira. Pensar também a questão da própria formação do professor, que a grande maioria dos professores tem uma formação única e acaba dando aula na EJA da mesma forma que ele dá aula no regular como para o fundamental... crianças para os jovens" (Prof. R., Dez., 2012).

Inferimos a partir daqui, a hipótese central para as quedas nas matrículas iniciais em EJA no Município de São Paulo, a inserção dos alunos de EJA no mercado aquecido de trabalho. Restou-nos a busca por essas comprovações. Identificar na administração das provas, sê, afirmase do geral para o particular ou infirma-se tal hipótese na comprovação dos dados que precisamos coletar. Foi a partir desse momento que buscamos nos dados quantitativos por variáveis que pudessem compor e sustentar esse pensamento.

A partir da entrevista do Professor R. formulamos tal hipótese e a procura de sua sustentação. Considerando que centralidade do trabalho na vida do aluno da EJA é condicionante fundamental na direção das suas vidas, precisamos perceber em que nível essa condicionante determina o problema da pesquisa. Perceber o que torna, ou não, determinante nos índices negativos de matrículas iniciais na EJA no período estudado. 
Recorremos à análise de conteúdo com a função heurística, de função exploratória. A partir da entrevista com o Professor R. prosseguiremos com a análise de conteúdo em função da "administração da prova". O passo seguinte na direção e prosseguimento da investigação a partir de nossa hipótese central foi à busca pelos índices oferta de trabalho no período da investigação.

\section{5 - A DESCOBERTA NA QUEDA DAS MATRÍCULAS INICIAIS DA EJA EM ÂMBITO NACIONAL}

Na comprovação da hipótese central formulada no item anterior, sob a base exploratória, quantitativamente, realizamos a produção de tabelas e gráficos com dados primários obtidos nas suas fontes e organizados, de acordo com a busca na presente pesquisa.

Recorremos às pesquisas e dados de institutos, como Dieese, FIPE, IBGE, e do Ministério do Trabalho que levantaram e analisaram os índices de trabalho no período entre 2000 a 2012, conforme disponibilidade dos dados nas suas respectivas instituições.

A partir da observação da Tabela 003 - Matrículas Iniciais EJA Fundamental I e II - Por Estados, elaboramos gráficos entre três variáveis:

Evolução das Matrículas EJA - Ano a Ano 2001- 2012 - Objetivando identificar os níveis de evolução ano a ano nas matrículas de EJA e na busca de uma grade temporal que se apresentasse no processo;

Crescimento do número de Carteiras de Trabalho Assinadas Administração da prova rumo à comprovação de nossa hipótese principal; Matrículas Iniciais - EJA - 2000-2012 - Comparativa ao quadro das Carteiras de Trabalho Assinadas, analisar possível vínculo entre os fenômenos (queda das matrículas iniciais - número das carteiras de trabalho assinadas) para afirmação ou infirmação da hipótese principal formulada; 
$\mathrm{Na}$ busca pelo entendimento das quedas nas matrículas iniciais da EJA no Município de São Paulo e pela determinante que sustente a base do nosso pensamento quanto ao fenômeno, voltamos às tentativas exploratórias, aos nossos "pacientes rodeios".

Com base no Quadro 013 (APÊNDICE "A") - organizamos gráficos que possibilitaram uma observação mais atenta na evolução das matrículas de EJA em todos os Estados brasileiros, ANO/ANO, onde pudemos observar suas frequências e pontuar o momento em que as quedas emergiram, estado a estado. Tal tarefa gerou 27 gráficos, dos quais constam no APÊNDICE "F". Classificamos esses gráficos em dois grupos:

Em oscilações negativas - refere-se aos estados que em alguns momentos apresentam índices menores nas suas quedas, ou até certo aumento de matrículas, mas considerado todo o período de 2001-2012, predominantemente apresentaram índices em quedas nas matrículas, são estes: $A C ; A L ; E S ; M T$ e MG.

Em quedas predominantes - refere-se aos estados que apresentam quedas ou números negativos de evolução nas matrículas em todo o período de 2001-2012, são estes: AM; AP; BA; CE; DF; GO; MA; MS; PA; $\mathrm{PB}$; $\mathrm{PR}$; $\mathrm{PE} ; \mathrm{PI}$; RJ; RN; RS; RO; RR; SC; $\mathrm{SE}$; $\mathrm{SP}$ e TO.

Abaixo apresentamos dois gráficos representativos destes grupos: São Paulo (base inicial desta pesquisa) e do Acre:

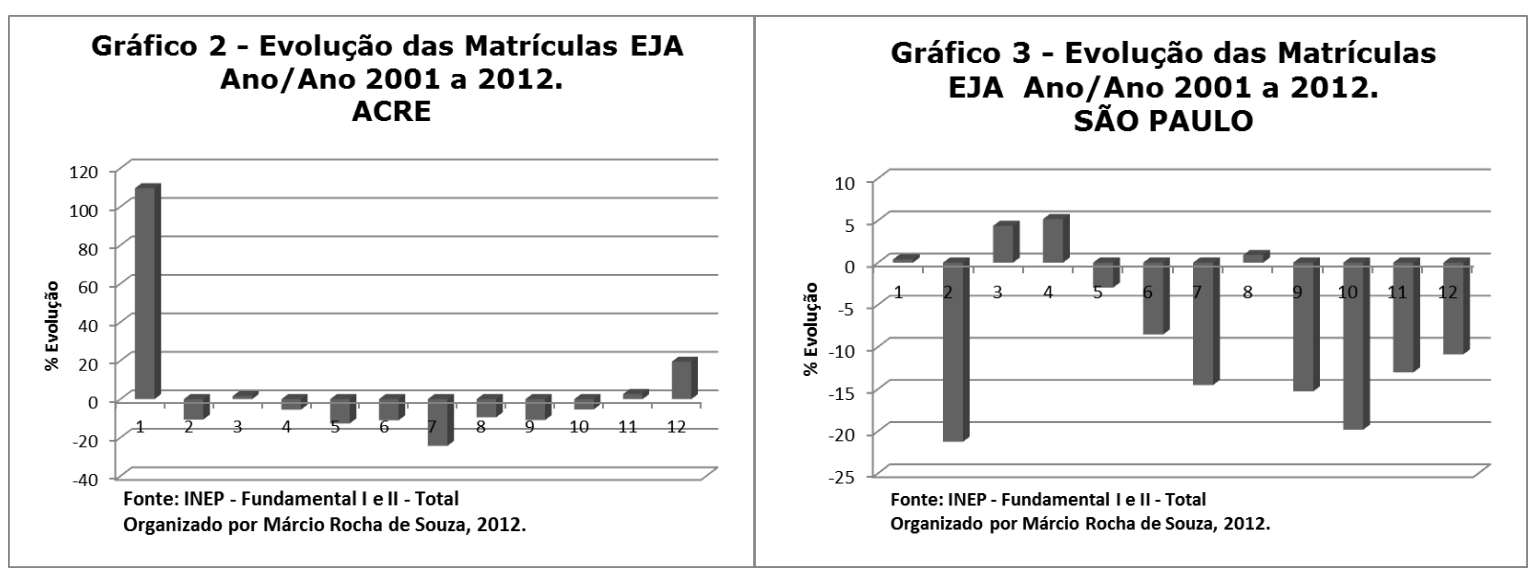


Quando observados os gráficos em todos os estados brasileiros são predominantes as quedas nas matrículas iniciais em todos eles, ou, os índices negativos contínuos nas matrículas da EJA. Comparados no conjunto de todos os Gráficos de Evolução de Matrículas EJA organizados Ano/Ano, deduzimos o ano de 2008 enquanto o período de predominante de queda - ou dos índices negativos nas matrículas da EJA não somente na cidade de São Paulo, mas nacionalmente.

A evolução das matrículas apresenta-se em variáveis negativas quase na totalidade dos Estados brasileiros, em 22 dos 27 estados da Federação. Elas não só caem, mas passam em índices negativamente expressos, quase sinalizando uma mensagem. Resta-nos desvendá-la a partir daqui.

Abandonamos a Reorganização da EJA no Município no ano de 2008 enquanto hipótese provisória e enquanto determinante das quedas nas matrículas da EJA, esta se configura em certo grau como condicionante local, entre quedas nas matrículas ou até evasões, mas não como a determinante. Este dado compôs em alguns aspectos estudados, como condicionante para a EJA paulistana, mas não explica em si a queda acentuada, bem como, a queda nos outros estados da federação. Em São Paulo este dado é parte de outros processos mais complexos que circularmente abarcam o cotidiano dessa modalidade de ensino.

Nesta pesquisa não conseguiremos abarcar caso a caso, em todos os estados em suas especificidades/problemas, mas buscamos uma explicação no fenômeno que possa ser considerado nacionalmente sustentado para essas quedas nas matrículas da EJA. Considerados os dados tratados até aqui, passam a imprimir uma determinante na redução das matrículas iniciais a ser buscada.

$\mathrm{Na}$ busca por mais uma comprovação dos dados, partimos do pressuposto que emergiu durante o processo metodológico desta pesquisa, o da centralidade do trabalho na vida dos alunos da EJA, para 
evocar em observação comparativa entre os dados das Matrículas Iniciais em EJA - 2000 a 2012 e Evolução das Carteiras Assinadas - 2000 a 2009 (anos/dados disponíveis na fonte).

Organizamos gráficos de todos os estados, com base na Tabela 3 e na Tabela 9. Abaixo o resultado de dois comparativos:
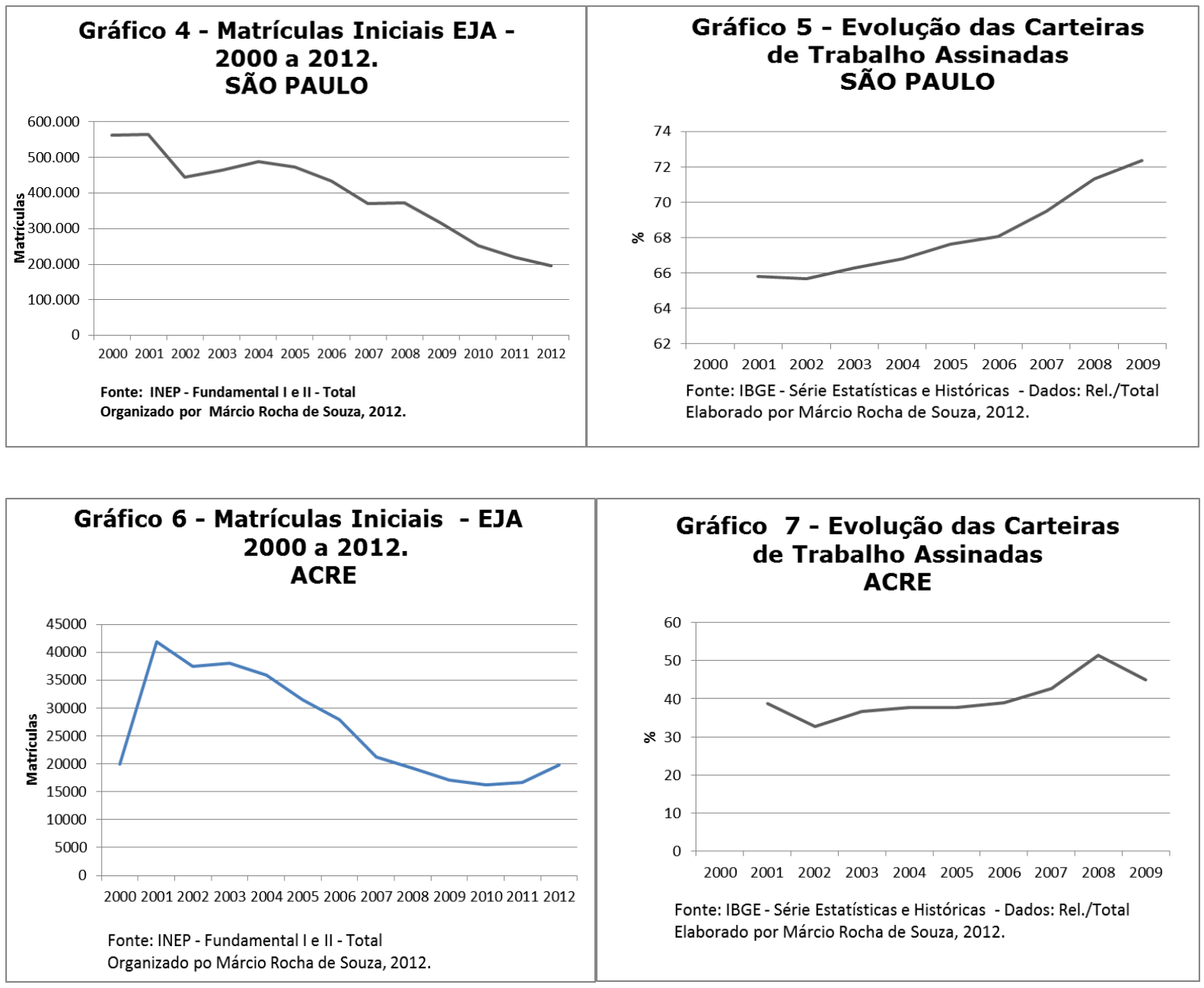

Tal comparação trouxe confirmação à nossa hipótese central. A tendência, na qual, à medida que caiam as matrículas na EJA pelo Brasil, elevavam-se os índices de trabalho com carteiras assinadas.

Quando comparamos os Gráficos das Matrículas Iniciais de EJA de cada Estado com os seus respectivos Gráficos de Evolução das Carteiras de Trabalho Assinadas encontramos nas fases de maiores quedas nos índices das matrículas em EJA, a tendência no crescimento dos índices de 
Carteiras de Trabalho Assinadas, ou, o crescimento da oferta de empregos com carteiras assinadas. Inferimos, então, que à medida que aumentaram as ofertas de trabalho formal, os alunos abandonaram a escola ou a ela não retornaram, após ingresso/reingresso no trabalho.

O crescimento na oferta do trabalho formal aponta tendência na determinante da redução nas matrículas iniciais da EJA no município de São Paulo e também em âmbito nacional. $\mathrm{Na}$ afirmação desse pensamento, buscamos ainda, por mais algumas variáveis, enquanto administração das provas e validação das hipóteses. Buscamos por dados que estendessem a grade temporal na análise dos índices de crescimento do trabalho no Brasil, até o mais próximo do ano de 2012, grade adotada no comparativo das Matrículas Iniciais.

Os dados "base" dos gráficos da Evolução das Carteiras de Trabalho Assinadas estavam disponíveis somente até o ano de 2009. Encontramos nos resultados da PNAD 2011, a Evolução dos Rendimentos de Trabalho nas Grandes Regiões, entre o período de 2009 para 2011, como segue no gráfico abaixo:

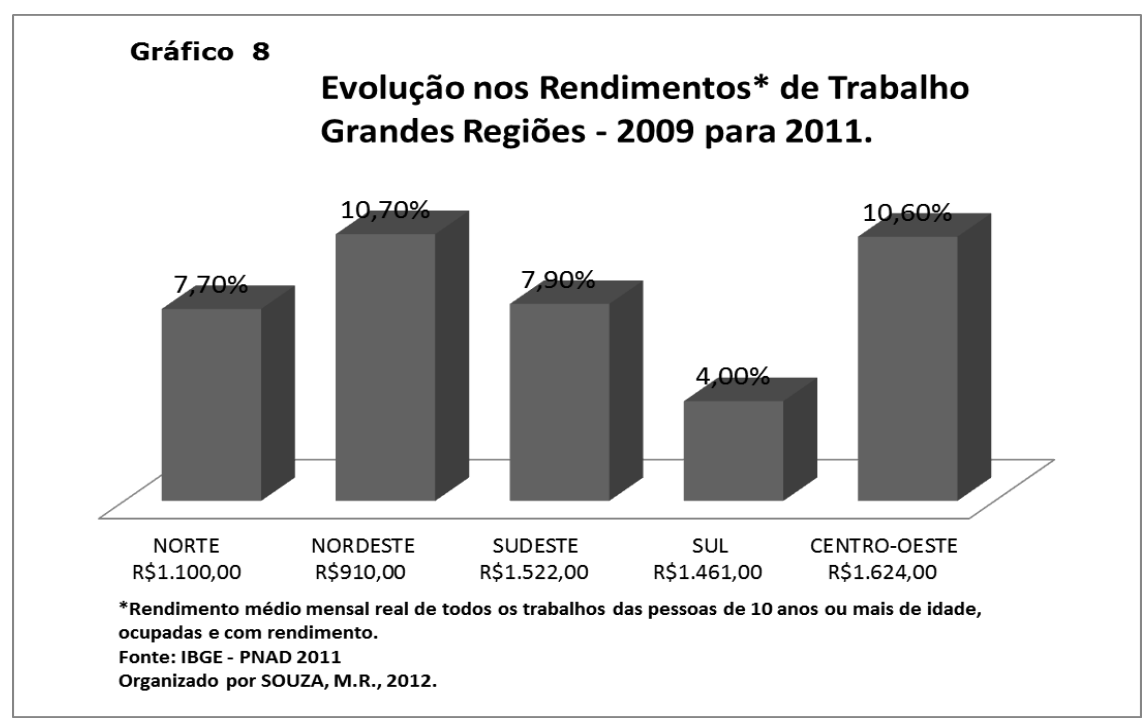

O crescimento dos rendimentos de trabalho nas grandes regiões entre o período apresentou índices de crescimento em todas as regiões administrativas brasileiras, com destaque desse aumento nas regiões 
nordeste e centro-oeste, apontando o maior rendimento médio mensal para o centro-oeste.

Vale esclarecer que a nossa opção qualitativa / quantitativa em Bardin (1977), inicialmente, partiu como lógica de contra argumentação às ciências de base liberais, e a seus pensadores que comumente partem das "certezas" da exatidão dos números, estatísticas e inventários infinitos no caminho para perpetuarem suas verdades, como contra argumentação aos nossos futuros debates.

Transpor esses dados a uma realidade com base nas ciências humanas de considerações múltiplas, complexas - em busca de análise qualitativa. Nesse caminho, apropriamo-nos do Relatório "Comunicação Social" do IBGE, que trata em parte dos resultados da Pesquisa Nacional por Amostra de Domicílios - 2011 para análise dos dados acima.

Segundo esse relatório, o rendimento médio mensal real de todos os trabalhos das pessoas de 10 anos ou mais de idade, ocupadas e com rendimento cresceu $\mathbf{8 , 3 \%}$, ainda observa, que o maior aumento destes rendimentos do trabalho se deu entre os $10 \%$ com rendimentos mais baixos. Traduzindo esse coeficiente percentual, de 2009 para 2011 houve um aumento de 3,6 milhões de empregados com carteira de trabalho assinada no setor privado.

Quando o relatório trata do Mercado de Trabalho e da relação da população ocupada, constata que apesar de certa queda nos índices de crescimento das pessoas ocupadas entre o período, houve aumento no contingente de ocupados para todas as faixas etárias, a partir de 30 anos de idade. Observamos, então, o gráfico abaixo fornecido pelo IBGE e adaptado para a pesquisa: 


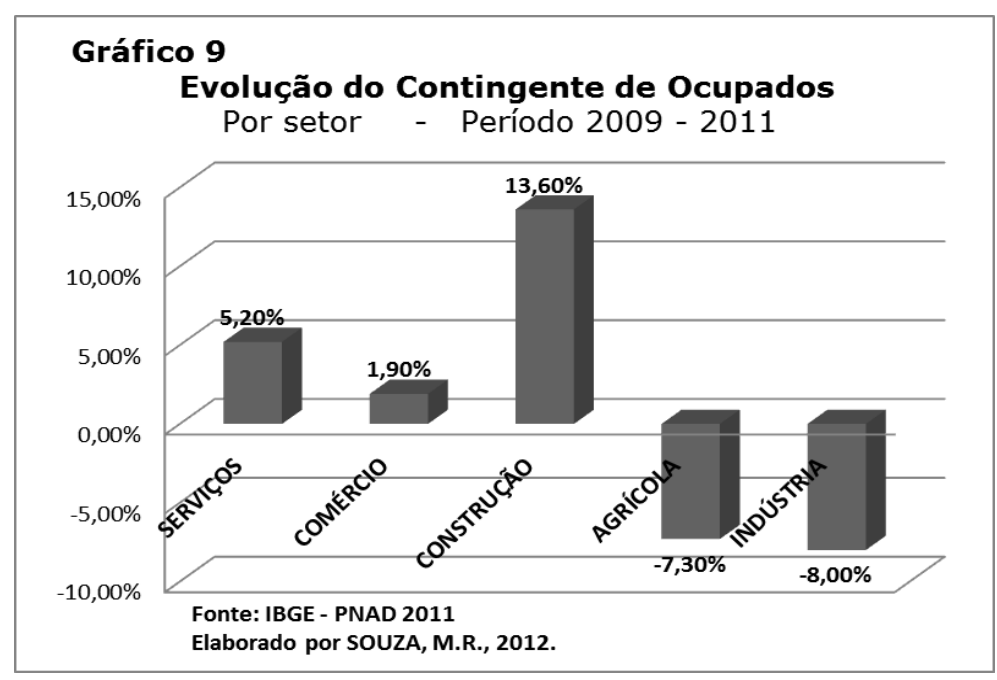

Dos setores que mais empregaram no período, constatou-se que o contingente de ocupados aumentou nos setores de serviços, comércio e construção civil, observamos neste dado que o crescimento da oferta do trabalho nestes "ramos produtivos de baixo grau de organização laboral e empresarial" (POCHMANN, 2007, p.197) atinge o perfil dos alunos da EJA.

Entendemos desta consideração que significativa parte dos contingentes de trabalhadores ocupados, potencialmente, são pessoas que no período evadiram progressivamente dos cursos da EJA ou não retornaram a eles, considerando enquanto determinante em suas vidas a centralidade no trabalho, aliada às oportunidades de melhoria de salários e consequente possibilidades de sustento financeiro ou consumo almejado.

Os problemas da EJA expandem-se na sociedade brasileira, impondo-se "opressivamente-repressivamente" (LEFEBVRE, 2006, p.37), vão além das quedas nas matrículas, primeiramente, emergem de processos de exclusão social complexos, que não daremos conta de desvelá-los neste trabalho, mas não poderíamos deixar ao menos de apontá-los.

Desses processos de exclusão, segundo Haddad (2007, p.204-208), a precariedade econômica de grande parte das famílias brasileiras contribui para o precoce ingresso das crianças no mercado de trabalho. 
Apesar da crescente oferta de vagas nas décadas de 80 e 90, a universalização do atendimento escolar ainda não ocorreu, pois no Brasil mais de dois milhões de crianças entre 5 e 14 anos estão fora da escola. Que a renda está associada a todos os outros fatores externos que determinam e exclusão educacional.

Por fim, é falsa a ideia de que no Brasil atingimos a universalização do ensino fundamental. Apesar do aumento do número das vagas e verdadeiro o aumento das matrículas, contraditoriamente, a baixa qualidade do ensino, aliada à baixa qualidade de vida da população, fazem com que esses alunos não completem sua escolaridade por incapacidade de adquiri-la, dadas tais condições.

Ainda, Haddad (2007, p.210) conceitua essa situação enquanto exclusão pela inserção precária. O professor e toda a força do trabalho docente inserem-se pela mesma lógica da precariedade institucionalizada.

A categorização na pesquisa emergiu da organização dos dados em inventários exploratórios que possibilitaram a análise das frequências, validadas na busca por outras variáveis que convergiram em afirmação da hipótese central, como no caso das entrevistas e questionários. A descrição dos dados e sua apresentação seguiram, concomitantemente, à nossa interpretação. A partir dessas considerações, estruturamos as próximas seções. 


\section{O ENSINO DA EJA PARA ALÉM DO MUNICÍ́PIO DE SÃO PAULO.}

A Educação de Jovens e Adultos no município de São Paulo constituise em complexidade tal que de certo aspecto representa significativa realidade do que temos observado no Estado de São Paulo e mesmo nos demais estados do País.

Essa realidade foi observada a partir de nossos primeiros estudos sobre a CONFINTEA VI ${ }^{10}$ e das suas ações preparatórias organizadas nos Fóruns de EJA - FORUMEJA - em todo o Brasil e que após o levantamento dos dados para esta pesquisa essa tendência foi reforçada.

O relatório do Fórum paulista, Di Pierro (2008), nos remete a essa realidade. Segundo esse documento ao ser analisada a questão do analfabetismo no Brasil ao longo dos últimos quinze anos percebeu-se lento e contínuo declínio nos índices percentuais, mas ainda há parcela significativa de pessoas que não sabem ler ou escrever. O relatório mostra desigualdades entre as regiões estudadas e no interior dessas, entre os territórios considerados urbanos e rurais. No conjunto da população analfabeta há o predomínio das pessoas negras, mais pobres e idosas.

Quando seus autores voltam à análise ao Estado de São Paulo, isoladamente, demonstram que não escapamos à realidade brasileira, apesar da posição econômica paulista hegemônica perante outros Estados da Federação, os autores atribuem a esse fenômeno à desigual distribuição de riqueza.

No Estado de São Paulo a taxa de analfabetismo é de 5\%, portanto,

${ }^{10}$ A UNESCO tem organizado uma série de reuniões internacionais intituladas CONFINTEA - Conferência Internacional de Educação de Adultos que acontecem a cada 12 ou 13 anos desde o final da década de 40 (Dinamarca 1949, Canadá 1960, Japão 1972, França 1985 e Alemanha 1997). Em 2010, pela primeira vez, realizado num país do Hemisfério Sul do planeta em Belém, PA - Brasil. Fonte: Disponível em http://www.unesco.org/pt/confinteavi/background/ em 30 jan 2012. 
inferior à nacional, no entanto, em relação ao contingente de pessoas analfabetas ocupa o segundo lugar, superado apenas pela Bahia. Assim havia mais de um milhão e meio de paulistas que não sabiam ler ou escrever, e a maioria se encontrava na faixa superior a 50 anos de idade.

O relatório demonstra que os paulistas totalizam onze milhões de pessoas com mais de 15 anos que não completaram o Ensino fundamental. Em 2008, a principal política pública de alfabetização do Governo Federal era o Programa Brasil Alfabetizado, contraditoriamente, neste período apenas 68 prefeituras paulistas estabeleceram convênios com o MEC. É preciso lembrar que o Estado de São Paulo está dividido em 645 municípios.

O atendimento à EJA tem sido dado através de organizações da sociedade civil oferecendo alfabetização e qualificação profissional, mas a maioria dos atendimentos educacionais aos Jovens e Adultos paulistas realiza-se pelas redes municipal e estadual de ensino.

Ainda no ano de 2007 de acordo com o Censo Escolar havia 933.825 matrículas na escolarização básica para Jovens e Adultos, destas, $81 \%$ presenciais e $19 \%$ semipresenciais. No Ensino Fundamental as matrículas nestas modalidades somaram 448 mil estudantes cerca de $3 \%$ da demanda, indicando claramente que 0 atendimento educacional aos Jovens e Adultos é insuficiente, considerando as reais necessidades sociais.

Esclarecem que apesar de o Governo Estadual responder por $70 \%$ das matrículas no conjunto da educação básica, são os municípios responsáveis pelo atendimento às séries iniciais do ensino fundamental para os Jovens e Adultos. Este processo iniciou-se a partir de $1990 \mathrm{com}$ a extinção da Fundação Educar ${ }^{11}$, na reforma do ensino que se deu na rede

${ }^{11}$ A Fundação Educar surgiu em 1985 - em substituição ao MOBRAL (Movimento Brasileiro de Alfabetização), criado em 1967 - desempenhou um papel relevante na atuação do Ministério da Educação junto a Prefeituras municipais e organizações da 
Estadual Paulista com os processos de municipalização ocorridos no mesmo período.

Aos municípios coube gerar as necessidades de matrículas ao atendimento das séries iniciais do ensino fundamental da Educação de Jovens e Adultos, tarefa nada simples, diante da política de fundos adotada pelo Governo Federal, pois as matrículas para o ensino de Jovens e Adultos não podiam ser contabilizadas nos cálculos de recebimento dos valores do FUNDEF - Fundo de Manutenção e Desenvolvimento do Ensino Fundamental e de Valorização do Magistério.

Sendo assim, evidenciam que muitos Governos Municipais não dispunham de recursos, muitas vezes também não tinham vontade política suficiente para priorizar essa modalidade de ensino. Isso se traduz na tímida evolução das matrículas da Educação de Jovens e Adultos entre os anos de 2002 e 2004 e uma queda real nos anos de 2005 a 2007. Somente em 2007 com a criação do FUNDEB - Fundo de Desenvolvimento da Educação Básica houve um aumento nas expectativas de atendimento à Educação de Jovens e Adultos, que inclui todas as modalidades do ensino, apesar de maneira diferenciada também inclui a EJA, Haddad (2007).

Os autores do Relatório Diagnóstico elaborado pelo Fórum Paulista da EJA refletem a situação em que se encontra a EJA não somente no Estado de São Paulo, mas em todo o Brasil e em inúmeros outros países como aligeiramento na ação, precarização das condições de execução, despreparo dos recursos humanos envolvidos e constatação de uma Educação Básica na EJA que se destaque pela qualidade.

sociedade civil, com destaque nos movimentos sociais e populares. Foi extinta em 1990 pelo governo de Fernando Collor de Melo. Desta forma, este governo ausenta-se como articulador e indutor de uma política de alfabetização de Jovens e Adultos no Brasil. Fonte: SILVA, A.M. Disponível em http://www.artigonal.com/educacao-artigos/educacaode-jovens-e-adultos-eja-no-brasil-1046328.html, 16/04/2013. 
Cabe expor algumas especificidades encontradas nessa modalidade de ensino no Município de São Paulo, zona Sul, com base nas escolas pesquisadas.

\section{1 - A EJA NA ZONA SUL DA CIDADE DE SÃO PAULO}

Partimos da vivência com a Educação de Jovens e Adultos tanto no ensino estadual como no municipal de São Paulo para as primeiras incursões e observações sobre esta modalidade de ensino nas escolas pesquisadas.

Os relatos neste item emergiram da observação ao longo do processo da pesquisa. Neste período, os registros colhidos foram em diferentes fontes, informais, observações no cotidiano escolar, pesquisa documental específica, como os diários de classe, relatórios de coordenações pedagógicas, planos de aula, desenvolvimento e ou acompanhamento de projetos, entre outros documentos que selecionamos no decorrer da investigação nas unidades escolares.

Na EJA na zona Sul da cidade de São Paulo, nos últimos oito anos, os espaços para as discussões abertas e amplas têm sido cada vez mais exíguos. Os principais agentes que deveriam participar de algumas delas, o aluno e o professor, muitas vezes protagonizam um papel secundário dentro do debate, com participações indiretas, representados por grupos que não refletem as suas experiências e expectativas e as possíveis soluções para os problemas apresentados no cotidiano escolar de professores e estudantes.

Das ideias protagonizadas pelos "representantes" da fala do aluno e do professor, algumas mudanças na organização de EJA foram ensaiadas, como a da Reorganização da EJA no ano de 2008 promovida pela Secretaria de Educação Municipal, que no período implantou uma reforma 
com muitos conflitos que no ano seguinte, em 2009, retrocedeu nos seus pontos polêmicos.

Das ações propostas em tais melhorias educacionais, passam de longe o aluno e o professor. Nas mudanças cabem a esses dois sujeitos apenas o cumprimento de novas determinações educacionais, enquanto sujeitos subalternos no processo. Os programas educacionais para Educação de Jovens e Adultos em certos momentos avançam e, em outros, retrocedem.

Dessa desordem, ou do não entendimento desses processos, as tentativas de melhoria dessa modalidade de ensino tem passado por constantes fracassos. A busca que, ora, desenvolve-se nessa pesquisa tenta desvelar ou desmistificar alguns equívocos sustentados há muito por determinados segmentos/grupos, que por vezes, percebemos cada vez mais se beneficiarem do seu ocultamento.

Das primeiras incursões nas escolas selecionadas na zona Sul da cidade de São Paulo, dos objetivos centrais aos objetivos específicos inicialmente pensados, dissolveu ou não se sustentaram à medida que avançávamos em todos os intrincados processos na busca ao desvelamento dessa realidade na redução/queda das matrículas iniciais na EJA.

Alguns equívocos sustentados inicialmente durante os primeiros passos na organização da pesquisa dissolveram-se. Sustentados por uma "explicação" embasada no senso comum e que até aquele momento serviram às intenções bem definidas, tratando-se das políticas públicas locais.

Como vimos na seção anterior, percebemos no avanço da pesquisa que o processo de quedas nas matrículas na EJA não seria possível de ser compreendido somente pela análise da estrutura e do funcionamento do Sistema Municipal de Educação paulistano. Embora tenha auxiliado, como referencial inicial para desencadear o avanço da pesquisa para além do 
Município de São Paulo. Sentimos necessidade de ampliar nossa escala de observação, para em seguida reduzi-la e entendê-la melhor.

Dos problemas apontados pela Secretaria Municipal de Educação S.M.E. e da nossa vivência na EJA, pudemos observar os discursos sobre as propostas de melhoria para EJA e aos seus rumos, o que nos levou a ampliar nossa reflexão na dialética, mediante a complexidade apresentada quando tratamos das manifestações e reproduções sociais, longe da abordagem das ciências, que muitas vezes professam certezas de uma história linear das coisas, sustentadas por uma história oficial e de interesses específicos.

Tais inquietações nunca repousaram, mesmo depois do ingresso na pós-graduação, apareciam nas questões dos grupos de trabalho coletivo nas escolas, nas reuniões pedagógicas ou nos raros momentos de encontros entre os professores em outras unidades escolares.

Das discussões em torno dos problemas observados de forma empírica, das tentativas e possibilidades de trabalhos que pudessem melhorar essa modalidade do ensino, apontavam caminhos indicadores de algo além de discussões mais pontuais ou do que nossos olhos conseguissem perceber. O fracasso escolar, muitas vezes, passa por uma análise direta e certeira dentro dos grupos que as montam, ou as desmontam e as remontam, a partir de políticas públicas para a Educação.

A Reorganização da EJA em 2008 na cidade de São Paulo movimentou o cotidiano escolar. Desta proposta ecoam acusações pelo seu fracasso até aos nossos dias. A Portaria 4917/07 S.M.E. publicada em Diário Oficial do Município em 02 de Outubro em seus preâmbulos, afirmou que

[...] à desejada democratização, e considerando a diversidade da população demandante, deve incorporar flexibilidade no currículo, nos espaços e nos tempos escolares, permitindo percursos variados, adequados às realidades dos participantes, que se caracterizam, sobretudo, pela condição de trabalhadores com as 
mais diferentes histórias de vida, que comportam pluralidade de objetivos, saberes, experiências e responsabilidades (SÃO PAULO, 2008, p. 11).

Os trabalhos para essa reorganização deram-se a partir de 07/02/2007, com a participação de 16 representantes das Coordenadorias de Educação, com os técnicos responsáveis pelos cursos de EJA em cada uma dessas coordenadorias no município de São Paulo. Grupo constituído pelo Comunicado SME no 536 de 04/04/2007.

Somente no início do ano letivo de 2008, alunos e professores tiveram ciência da totalidade da Reorganização e das mudanças para a EJA. Com tal reorganização, muitos conflitos se estenderam dentro e fora das unidades escolares, todas as partes envolvidas nesse processo mostravam descontentamento. A flexibilidade tão utilizada nos discursos para justificar a reorganização para atender as necessidades de alunos e professores denominados por "participantes" não pautavam pela mesma flexibilidade nas questões de organização das atribuições de aulas.

Um exemplo dessa contradição estabeleceu-se na estrutura e organização entre os criados "Eixo Central" e "Eixo Variável" dos eixos formativos estabelecidos pela Portaria 4.917 de 02/10/2007, publicada no Diário Oficial do Município - D.O.M. de 03/10/2007 para a "Nova EJA".

Entre os objetivos de criação desses eixos estabelecidos na referida Portaria e de sua execução havia um fosso de contradições que inviabilizava a sua realização efetiva. Entre estas contradições, atemo-nos neste momento a elucidar o que se estabelecia entre tais eixos, segundo Portaria 4.917/2007:

Eixo Central - composto por áreas de conhecimento da Base Nacional Comum do Currículo do Ensino Fundamental, com duração e carga horária definida e frequência obrigatória; [...] Art. 40 - Na organização do Eixo Central observar-se-ão, ainda, as seguintes diretrizes: I - carga horária diária, obrigatória para os alunos, de $2 \mathrm{~h} 30 \mathrm{~min}$., sendo: a) $2 \mathrm{~h} 15 \mathrm{~min}$ ( 3 horas-aula) - aulas regulares; b) 15 min. - intervalo, cujo aproveitamento será orientado em projeto específico da Unidade Escolar; [...]Art. $5^{0}$ - O Eixo Variável será composto de atividades de Orientação de Estudos, destinada a: I - propiciar aos alunos momentos de 
atenção individualizada para dirimir dúvidas, oferecendo-lhes atendimento diferenciado; II - desenvolver recuperação de conteúdos; III - orientar e incentivar a pesquisa; IV - realizar projetos específicos. $\S 10$ - A Orientação de Estudos será realizada em hora-aula, de 45 minutos, em horário imediatamente antecedente e/ou imediatamente subsequente ao das aulas regulares, de oferta obrigatória e planejamento da Unidade Escolar e de frequência facultativa para os alunos. $\S 20$ - As aulas de Orientação de Estudos poderão ser utilizadas para compensação de ausências justificadas às aulas do Eixo Central, desde que ministradas por Professor devidamente habilitado (SÃO PAULO, 2008, p.144-149).

quadro abaixo elucida a situação de reorganização proposta acima:

\begin{tabular}{|c|c|c|c|c|c|c|}
\hline \multicolumn{7}{|c|}{$\begin{array}{l}\text { Quadro } 12 \\
\text { Ilustrativo }\end{array}$} \\
\hline Aulas & Horários & Segunda & Terça & Quarta & Quinta & Sexta \\
\hline 19 aula & 19h00-19h45 & Eixo Variável & Eixo Variável & Eixo Variável & Eixo Variável & Eixo Variável \\
\hline 2a aula & $19 \mathrm{~h} 45-20 \mathrm{~h} 30$ & Eixo Central & Eixo Central & Eixo Central & Eixo Central & Eixo Central \\
\hline 3a aula & 20h45-21h30 & Eixo Central & Eixo Central & Eixo Central & Eixo Central & Eixo Central \\
\hline 4a aula & $21 \mathrm{~h} 30-22 \mathrm{~h} 15$ & Eixo Central & Eixo Central & Eixo Central & Eixo Central & Eixo Central \\
\hline 5a aula & 22h15-23h00 & Eixo Variável & Eixo Variável & Eixo Variável & Eixo Variável & Eixo Variável \\
\hline
\end{tabular}

Na mesma Portaria, entre os Artigos 14, 15 e 16 rezam os critérios de atribuição dessas aulas entre Eixo Central e Variável e na execução/prática emergiram muitos problemas. No cumprimento destas determinações os professores ficavam sob uma estrutura inflexível de atribuição.

Um exemplo disso era que na maioria dos casos, o professor regente do Eixo Central não conseguia compor jornada para atender os seus próprios alunos na grade do Eixo Variável, ou seja, nos projetos de reforço, por exemplo. Um terceiro professor entrava neste eixo para atender as dúvidas das aulas/conteúdos do professor do Regente no Eixo Central.

Considerando todas as peculiaridades que envolvem o cotidiano escolar dentro de uma estrutura como a do Município de São Paulo e da sua complexidade logo se percebeu que muitos professores entre os Eixos Centrais e Variáveis muitas vezes nem se cruzavam. 
Nesta perspectiva, como atender às necessidades específicas desse aluno? Quem atenderia esse aluno? Como fazer acontecer o entrosamento pedagógico necessário no desenvolvimento desse Projeto pensado em Portaria? Esse foi um dos muitos aspectos que fizeram desta reorganização da EJA no Município de São Paulo um "caos", segundo vários relatos colhidos entre os professores nas três unidades escolares pesquisadas.

Outro ponto de polêmicas implícito nessa portaria refletia sobre o número de aulas atribuídas a cada professor da EJA. Muitos professores tiveram suas aulas reduzidas no noturno e para complementar jornada foram obrigados a migrar para outros turnos ou outras unidades escolares, quando possível, uma vez que o professor detentor das aulas atribuídas no Eixo Central não conseguia ministrar aulas de Orientação no Eixo variável para suas turmas, por determinações da própria Portaria.

Os alunos também alegavam que os horários não os atendiam, os professores alegavam que era difícil a composição de suas aulas com esses novos horários e, em alguns casos, perderiam suas jornadas de trabalho ${ }^{12}$. Durante o ano letivo, as equipes gestoras nas unidades perdiam-se em meio a tantas questões. Diante de tantos desentendimentos e diante às resistências ao novo projeto de EJA, as Diretorias Regionais de Educação e a Secretaria Municipal de Educação

${ }^{12}$ A jornada de trabalho docente para o ano de 2008 - publicada em D.O.M. em 25/01/2008, p. 14, regida pela Portaria 647/2008: JB - Jornada Básica 20 horas/aula semanais, sendo 18 horas/aula de regência e 02 horas/atividade ; JBD - Jornada Básica do Docente corresponde a 30 horas/aula semanais, sendo 25 horas/aula de regência e 05 horas/atividade; destas, 03 a serem cumpridas obrigatoriamente na escola e 02 em local de livre escolha e JEIF - Jornada Especial Integral de Formação corresponde a 40 horas/aula semanais, sendo 25 horas/aula de regência e 15 horas/adicionais; destas, 11 a serem cumpridas obrigatoriamente na escola e 04 em local de livre escolha. Fonte: http://www.sinpeem.com.br/lermais materias.php?cd materias $=1550 \&$ friurl=: - Portariano-647-DOC-de-25012008-pagina-14-: em 15/01/2012. 
alegavam que o problema centrava-se em questões do corporativismo entre os professores.

Essa reorganização também não foi um processo de transição planejado entre as bases envolvidas, o aluno e o professor, o que dificultou a assimilação da nova estrutura por esses sujeitos e provocou toda uma discussão e pedidos, via sindicatos, por alterações no projeto inicial proposto pela Secretaria Municipal de Educação.

A Secretaria argumentava a todo tempo que as mudanças foram em atendimento às reivindicações realizadas sob os estudos anteriores, além do que, seria um passo adiante na "modernização" do Ensino da Educação para Jovens e Adultos (SÃO PAULO, 2008, p. 12), porém, dessa inovação os professores e alunos alegavam desconhecimento.

O fato é que a Educação para Jovens e Adultos e as unidades escolares desestabilizaram-se na sua rotina e atendimento. Os projetos em andamento, de curto ou longo prazo, se perderam com a alteração estrutural das aulas e a sua desconexão dos objetivos. Professores e alunos viram-se desmotivados e, porque não dizer, desmobilizados na interação ensino aprendizagem.

Foi a partir desse debate que tal projeto de reorganização em 2008, após negociações sindicais, teve algumas alterações, nos pontos que conflitavam interesses como os horários de aulas e sobre a jornada docente semanal. O movimento reivindicatório levou à extinção do Eixo Variável a partir do ano de 2009, passando todas as aulas para o Eixo Central. Vale ressaltar neste momento que toda essa mudança realizou-se sob a base de um mesmo governo, o de Gilberto Kassab, em seu primeiro período de governo após a renúncia de José Serra no ano de 2006 o qual havia saído para concorrer às eleições estaduais. 
No início do ano letivo de 2009, constatamos que o número de alunos na EJA caiu drasticamente nas três unidades escolares do bairro na zona Sul de São Paulo.

Percebemos que muitos alunos não haviam se transferido, sem conclusão dos seus estudos, muitos desistiram, não voltaram a se matricular no ano seguinte. Esse dado está baseado inicialmente em pesquisa feita empiricamente por professores de uma das unidades escolares. A pesquisa foi realizada no entorno do bairro, acessando algumas instituições como igrejas e a associação de moradores do bairro, casas e as comunidades em favelas atendidas pelas unidades, onde foram realizadas campanhas por aumento das matrículas.

A tendência às quedas nas matrículas da EJA, no ano de 2009 , foi observada também nos relatos informais e em alguns documentos analisados nas unidades escolares. O mesmo foi observado nos relatos de um grupo de professores de Geografia, reunidos na S.M.E., no qual estivemos presente em único encontro, realizado nos meses de outubro e novembro daquele ano, que tinha como objetivo geral de rever a prática do professor de Geografia na EJA.

No período inicial da pesquisa, buscou-se entender sobre as quedas nas matrículas e da redução de alunos nas salas da EJA na zona sul sob os aspectos acima descritos. Quando ampliamos a busca por essa resposta, sob a Metodologia em Bardin (1977), a política de Reorganização da EJA em 2008 no município de São Paulo não sustentava em si como uma das possíveis causas determinantes dessas quedas, embora tenha dado os primeiros indícios de nossa investigação e considerarmos válidas as pesquisas que apontam condicionantes nos caminhos do esvaziamento das salas de EJA por todo o Brasil, como as questões de formação do professor, condições materiais, políticas públicas, condições do aluno trabalhador, entre outras, situando-as, conforme seus locais e tempos de pesquisa. 
$\mathrm{Na}$ fase inicial da pesquisa a literatura consultada apontou os problemas que, de certa forma, dificultaram a descoberta de uma determinante ou condicionante que sustentasse os motivos dessa redução das matrículas na EJA, independentemente das condicionantes já colocadas em muitos trabalhos sobre o tema.

Apesar da escassez dos trabalhos de pesquisa em EJA quase a totalidade dos trabalhos que acessamos mostra as "desordens" em muitos aspectos em relação às políticas públicas para a EJA.

Fávero (2010) colabora para esse entendimento, em relato interessante dessas situações de desentendimentos e descontinuidades com a educação pública, como no caso do governo Federal nas duas gestões de Fernando Henrique Cardoso, entre 1995-2002. Nesta situação, especificamente, diferentes organizações que trabalhavam há tempos em programas de EJA pelo Brasil foram ignoradas quando da elaboração do relatório para a Confintea V, realizada no ano de 1997, em Hamburgo, na Alemanha.

Segundo Fávero (2010, p. 29-30) o governo F.H.C. não somente desconsiderou tais grupos e entidades em seus trabalhos, como lançou a Campanha "Alfabetização Solidária", inicialmente sustentada pela Presidência da República, depois, coordenada pela primeira-dama Ruth Cardoso, através de uma organização Não Governamental (ONG).

Fávero (2010) ainda nos relata sobre a reação da sociedade civil perante essa postura do governo de F.H.C. Essas entidades se organizaram em Fóruns de Educação de Jovens e Adultos, que atualmente atuam em todos os Estados e em muitos municípios brasileiros.

Destes participantes nos Fóruns por todo o Brasil, destacam-se universidades, secretarias de educação, sistema S (SENAI, SESI, SENAC, SESC), Organizações da Sociedade Civil, entre outras. Hoje, estes Fóruns estão constituídos como principais interlocutores no Ministério da 
Educação, por intermédio da Secretaria de Educação Continuada, Alfabetização e Diversidade - SECAD.

Nessa situação de continuidade da desordem encontramos o caso do Fundo de Manutenção e Desenvolvimento do Ensino Fundamental e de Valorização do Magistério - Fundef. Esse sistema de financiamento da Educação do Brasil ocorreu em 1996, aprovado pela Emenda Constitucional no 14, que entrou compulsoriamente em vigor em 1998. Segundo Haddad (2007, p. 217):

[...] Este fundo subvinculava, com destinação específica para o Ensino Fundamental regular, uma parte dos recursos já destinados à manutenção e desenvolvimento do ensino. Em tese, destinava-se reduzir as citadas disparidades entre as escolas das redes municipal e estadual de um mesmo estado, e reduzir as desigualdades entre os diferentes estados da federação, para o que dependia de contribuição financeira da União.

O autor segue esclarecendo que os resultados desse financiamento foram insuficientes para combater as disparidades regionais, pois os recursos disponibilizados nos estados com maiores valores per capita são mais de duas vezes superiores ao que dispõem aqueles situados no extremo inferior da escala, o que visto do ponto de vista das políticas de equidade trata-se de uma situação inaceitável.

Das causas que evidenciaram esse problema Haddad (2007) expõe que em primeiro lugar há grande disparidade na receita de impostos entre as diferentes regiões do país e, que em segundo lugar, embora previsto em Lei a União não entrou com um aporte significativo de recursos financeiros para os estados e municípios das regiões mais pobres. Outro efeito secundário desse financiamento é que na prática acabou gerando um nivelamento por baixo dos sistemas, do qual, penalizou os municípios que ofereciam ensino com padrão de qualidade diferenciada.

Lembremos que a EJA nesse aspecto ficou de fora mais uma vez, nesse processo, pois o financiamento era realizado somente sobre o Ensino Regular, o que segundo Haddad (2007, p. 216-217) desestimulou a 
oferta não somente para a EJA, mas também para a Educação Infantil, afetando os segmentos mais pobres da população.

Dessa situação de distorção, como proposta de suprir essa disparidade desse sistema de financiamento somente no segundo mandato do governo Lula surge em Projeto de Emenda Constitucional o FUNDEB - Fundo de Manutenção e Desenvolvimento da Educação Básica e de Valorização do Magistério - aprovado pelo congresso Nacional no final de 2006.

O Projeto do FUNDEB passa a financiar todo o Ensino Básico Infantil, Regular e EJA - porém, os problemas graves ainda permaneceram segundo Haddad (2007, p. 218-219). Desses problemas, o primeiro sinalizado é que a ampliação dos recursos foi inferior ao aumento ocorrido no número de alunos a serem atendidos; na prática significa que o valor médio per capita do FUNDEB será inferior àquele do FUNDEF. O segundo problema ainda é o da equidade, ou seja, a disparidade entre os valores per capita dos repasses desse fundo entre as Prefeituras, conforme número de alunos atendidos. Houve melhoria nesse ponto, mas a diferença entre o maior e o menor valor por aluno permanecerá ainda superior a duas vezes, perpetuando a situação inaceitável desse problema.

Ao observar a situação da EJA no Estado de São Paulo, percebemos que não são diferentes as situações de desordem. Tanto o Fórum do Estado de São Paulo para EJA ${ }^{13}$ em Di Pierro e Vieira (2008) quanto algumas organizações civis, como a Ação Educativa ${ }^{14}$ (2012) têm refletido sobre essa situação de desordem.

${ }^{13}$ FORUMEJA: Criado desde 1994 - Ambiente inicialmente virtual para encontros, debates e socialização dos conhecimentos em EJA - Organizado inicialmente por um grupo de docentes da Educação e do Instituto de Matemática da Universidade de Brasília. Disponível em: http://forumeja.org.br/brasil, em 10/09/2012.

${ }^{14}$ A Ação Educativa, Assessoria, Pesquisa e Informação é uma associação civil sem fins lucrativos fundada em 1994. Sua missão é promover direitos educativo, culturais e 
No âmbito municipal, a cidade de São Paulo não seria exceção nesse caminho das desordens. Apesar dos escassos estudos nessa área em EJA, encontramos algumas discussões em trabalhos acadêmicos nas Universidades. Algumas reflexões apontam as descontinuidades e descompassos protagonizados pela Secretaria Municipal de Educação S.M.E., como em Moreira (2008) e SILVA, R.N. (2013).

Certos aspectos dessa postura na gestão pública independem dos governos de plantão, mesmo em gestões de continuidade, após os resultados eleitorais.

Quando a partir de os resultados eleitorais são modificadas as estruturas de gestão pública, é comum o substancial abandono de programas e esvaziamento dos objetivos anteriormente sustentados pelas administrações derrotadas nas urnas. Dessa situação, encontramos alguns referenciais no pensamento de Jacobi (1996).

Os descompassos e descontinuidades são considerados como "desordem", por refletirem de maneira desastrosa a base da educação, a escola, na qual estão o aluno e o professor, como principais protagonistas.

A esta situação de desordem apropriamo-nos da exortação da Haddad (2007, p. 214): "se o Estado deixasse de organizar eleições como deixa de ofertar escolas de boa qualidade, certamente haveria maior indignação e reação".

Essa postura nas gestões dos últimos dez anos marca a Secretaria de Municipal de Educação de São Paulo, em especial, para a frágil situação sustentada por ela nos cursos para a Educação de Jovens e Adultos. Tal

da juventude, tendo em vista a justiça social, a democracia participativa e o desenvolvimento sustentável. Fonte: Disponível em http://www.acaoeducativa.org/index.php/quem-somos, 10/09/2012. 
postura não passaria incólume e deixaria sequelas, enquanto condicionantes no processo de quedas de matrículas.

Percebemos que as complexas situações que balizam 0 entendimento das ações que corroboram para um esvaziamento da EJA extrapolam os muros das escolas, os Gabinetes das Secretarias de Educação, indo além das causas mais visíveis dos problemas apresentados.

Os espaços concedidos para os debates coletivos que colaborariam para o entendimento dos caminhos dessas quedas de matrículas, e seus sentidos, estão cada vez mais exíguos. "Os protagonistas têm sido excluídos desses debates" (2007, p. 214). Carecem de maior atenção no processo de construção dos conceitos. Entendemos que estes espaços estão intrinsecamente ligados ao tempo capturado na cotidianidade.

Os descompassos são recorrentes e as ações propostas em função de sua urgência são tomadas como novas e, nesta perspectiva, resta apenas que se ofereçam os "remendos" aos problemas. Resolve-se o problema do momento, da ordem do dia ou das necessidades políticas vigentes. As "urgências" se tornaram a tônica nas políticas públicas desconectadas das reais necessidades (TELLES, 2006).

Algumas questões ficaram evidenciadas mais do que outras, entre elas, o tempo para discussões e organização de políticas educacionais para EJA e para a Educação de maneira geral.

Desta reflexão, consideramos importante o pensamento de Telles (2006) quando trata das questões urbanas. Reflete nas tramas e nas estruturas que formam a cidade de São Paulo enquanto a maior concentração urbana do hemisfério Sul. Desse pensamento, a Educação para os Jovens e Adultos evidencia-se em aspectos complexos, como um problema urbano, considerando-se as especificidades econômicas que compõem a cidade de São Paulo no que se refere ao restante do território nacional. 
[...] das "mil faces" do problema urbano. [...] O problema está nas nossas dificuldades de discernir o que anda acontecendo nos tempos que correm e perscrutar as linhas de força que os atravessam [...] É como se vivêssemos um presente inteiramente capturados pelas urgências do momento, e não restasse muito mais do que a sua gestão cotidiana, sem conseguir figurar e nomear as expectativas que lançam as linhas de fuga de futuros possíveis (TELLES, 2006, p. 43-44).

Analogicamente, à situação tratada por Telles (2006), ainda sobre as urgências, entendemos que a essa situação da EJA, da falta de medidas efetivas na valorização dessa modalidade de educação e a ausência de um debate crítico dos problemas que a assolam, impedem a descoberta de soluções para os problemas do seu cotidiano, o que também incluímos à Educação de maneira geral.

O tempo, o aporte teórico, a fragmentação dos conteúdos, a visão de mundo, o conceito de Educação dominante e as lacunas na formação do professor, dentre outros, que surgiram em nossas primeiras preocupações, hoje, entendemos enquanto condicionantes nos processos de quedas nas matrículas iniciais na EJA, situadas no local e no tempo.

Percebemos, até aqui, que os processos determinantes e condicionantes nas quedas das matrículas iniciais da EJA estão intrinsecamente vinculados aos processos produtivos capitalistas e do estágio de desenvolvimento desse modo de produção no Brasil, a saber, dos processos que alavancaram os índices de crescimento do trabalho formal no país e, que contraditoriamente, esvaziaram as salas de aula.

Analisar esse espaço e suas relações em escala ampliada torna-se fundamental para a afirmação de nossa hipótese central e para o entendimento do problema da pesquisa, como nos alerta Lefebvre (2006, p.133), ao menos provisoriamente. 


\section{A EJA NO CONTEXTO CAPITALISTA BRASILEIRO: EDUCAÇÃO E TRABALHO E SUAS CONTRADIÇÕES.}

Após refletir sobre os cursos de EJA no Brasil, e as formas pelas quais se desenvolveram assim como as ações para a sua efetivação e continuidade, percebemos que o problema da queda das matrículas nessa modalidade de ensino deva ser refletido no contexto capitalista brasileiro, tendo como centralidade o mundo do Trabalho o mundo da Educação e as Contradições desse processo, como categorias que emergiram no desenvolvimento da pesquisa.

Consideramos que para a necessária análise nas quedas das matrículas nos cursos de EJA pelo Brasil, no período de 2000-2012, temos que observar atentamente as necessidades intrínsecas de produção e reprodução do capital nacionalmente praticado, nos aspectos mais específicos, as suas forças produtivas e as relações sociais que dela emergem, nesse aspecto, tentar alcançar realidade do problema apresentado na pesquisa.

Alcançar a realidade do problema constitui a tarefa deste trabalho na tentativa de contribuir com algumas proposições, no sentido de tornar possível a real efetivação desses cursos para os Jovens e Adultos.

Há de se considerar nessa análise o momento diferenciado na história política e econômica contemporânea brasileira e que reflete em toda a sociedade de maneira geral, e conforme cada caso, de maneira específica. Procuramos cuidar para não cair no reducionismo das coisas. 0 procedimento da redução é científico, considerada a complexidade do que se quer estudar e das constatações imediatas desse estudo. É preciso reduzir, para em seguida "restituir progressivamente o que a análise afasta" (LEFEBVRE, 2006, p. 51).

O problema da redução, segundo Lefebvre (2006), é construir na análise um modelo reduzido das coisas da sociedade, cidade, das instituições, da família - e no nosso caso, um modelo redutor da análise 
aos problemas da EJA. O problema do reducionismo simplificado é tornar em verdades absolutas o que alguns discursos e intenções dominantes ocultam. Estratégia sofisticadamente elaborada de difícil percepção, mas é possível que sejam desveladas. Segundo Lefebvre (2006, p. 52):

\begin{abstract}
O reducionismo se introduz com ares de cientificidade. [...] Os reducionistas fazem elogio incondicional do procedimento inerente à ciência, depois a tranformam em atitude e em seguida em saber absoluto, com ares de ciência da ciência [epistemologia] [...] a redução sistematizada e o reducionismo correspondem a uma prática política.
\end{abstract}

Dos resultados constatados na pesquisa, esta seção insere-se nessa proposição, reduzir, para imediatamente restituir a análise. Partiremos do atual estudo que apontou o aumento nos índices do trabalho formal, ou seja, de carteiras assinadas, devido à maior oferta de emprego no Brasil nos últimos seis anos, que aponta ter contribuído no esvaziamento das salas da EJA.

Esse resultado evidencia o nível da centralidade do Trabalho na vida das pessoas. No caso dos alunos da EJA, considerada a fragilidade e o contexto social perverso protagonizado por esses jovens e adultos trabalhadores há uma contradição dialética entre o mundo da Educação e o mundo do Trabalho.

Evocamos inicialmente reflexão às "verdades" pronunciadas pelo pensamento liberal, sustentadas pelo senso comum: "estudamos para trabalhar". Essa lógica não responde ao mundo real, vivido. Não é raro ouvirmos alguns discursos em que o locutor se vanglorie da sua prosperidade, obtida sem a ajuda da escolarização, atribuindo à riqueza ao "seu trabalho". Esse pensamento linear também contribui para o mascaramento de todo o processo produtivo entre trabalho e a riqueza.

Outro ponto de estrangulamento nas tentativas de alavancar o entendimento do problema para a efetivação real da EJA converge-se no ocultamento dos princípios do capital. Não é raro também implícita ou explicitamente encontrar discursos em que caracterizam a EJA enquanto 
modalidade de ensino secundarizada, isto é, reforça a falsa ideia dessa modalidade do ensino "como uma 'reposição' de processos escolares 'perdidos', para preencher lacunas deixadas pela falta do ensino regular ou para completar o inacabado na época considerada adequada" (SÃO PAULO, 2007, p. 12, grifo nosso).

Perante o pensamento dominante tal proposição evidencia-se em dinheiro gasto em dobro, "perdido", o que na realidade torna-se evidente neste processo é a negação e o ocultamento de todo o contexto social que determinou o abandono escolar daquele aluno. Vejamos um trecho do discurso da S.M.E./Reorganização EJA.

[...] Ou seja, a dívida é paga agora, mas com moeda de épocas passadas [...] Mantem-se, desse modo, uma equivocada simetria da EJA com o ensino regular, transpondo-se, em menor tempo, de forma "miniaturizada" e ritualmente "escolarizada" a organização escolar do ensino regular destinado a crianças e adolescentes. Mesmo a oferta atual da Secretaria Municipal de Educação padece dessa concepção, apesar dos esforços de muitos, porém aprisionados por um currículo que, na prática, leva a essa transposição simétrica (SÃO PAULO, 2007, p. 12).

Convém esclarecer que o trecho citado mesmo quando parece defender legitimamente a Educação para os Jovens e Adultos, na Reorganização dos seus cursos de EJA em 2008, acabam por culpabilizar as vítimas pelo precário estado das coisas, a saber, o professor. A si justificam-se e vitimizam-se no discurso: "mesmo a oferta atual da Secretaria Municipal de Educação padece dessa concepção"; ausentam-se da responsabilidade institucional enquanto representante da educação pública na ordem vigente, mascarando o institucionalizado pensamento liberal que as produziu.

O que observamos empiricamente, e demonstraram os dados colhidos em campo - e mesmo o que outros estudos têm apontado - não ser determinante para a queda das matrículas na EJA a condição encontrada na oferta dos conteúdos oferecidos, não encontramos relatos 
de desistência ou abandono escolar pelo insatisfatório conteúdo oferecido aos seus alunos, apesar de certa condicionante.

O que se evidenciou nesta pesquisa partiu do resultado das entrevistas em campo, tanto as planejadas como as não planejadas, mas registradas, em que, significativas parcelas dos alunos da EJA relataram que apesar de perceber a importância da escolarização em suas vidas, a necessidade do trabalho para sobrevivência impediu em alguns momentos a continuidade dos estudos.

Dos relatos colhidos, muitos mencionavam a partir do horário de chamadas na sala de aula pelos seus professores, onde os colegas respondiam: "está trabalhando"; "trocaram o horário do trabalho e não deu para continuar"; "conseguiu trabalho e não consegue mais chegar no horário", entre outros relatos similares.

Desse conflito, questionamos: Logo, estudamos e trabalhamos por que / para quem?

O conflito revela-se mediante contradições impostas pela dinâmica à manutenção e perpetuação do capital. Dessa constatação, apropriamo-nos de Marx (2010) que revela na origem as contradições. Estas, provém tanto do anseio do homem como da sociedade humana e emergem de suas concepções de mundo.

A importância do trabalho na vida das classes trabalhadoras constitui-se na escala básica pela de sobrevivência, noção construída historicamente imposta no seu meio social, onde sem o trabalho restaIhes a mendicância ou a prisão (WACQUANT, 2001, p. 129).

O atual capitalismo não oferece escolhas diferentes das que em seus primórdios oferecia. Manteve a sua estrutura, alterações neste sentido surgem apenas quando e onde as forças produtivas necessitavam, e o que permitem nesse sentido são ajustes apenas, quando em decorrência das suas transformações históricas (MÉSZÁROS, 2008). 
Sob o capital a história mostra que na escola para o trabalhador independente de seu desejo de realização de escolarização, a escolarização que de fato acontece é a que the consentem ou the concedem e mesmo dessa consideração, transcorre-lhe tortuoso caminho. O entendimento de tais contradições, talvez, se encontra no cerne do problema: interesses antagônicos, enquanto classes, interesses de classes sociais.

Sobre esse conflito e o acirramento das contradições, encontramos em Lefebvre (2006, p.12) que as bases das contradições emergem diante de interesses múltiplos e complexos nas sociedades capitalistas. O interesse individual pode opor-se ao interesse coletivo, ao qual frequentemente se opõe e revela-se no transcorrer histórico. Revelam-se as paixões dos indivíduos e de certos grupos ou classes, das quais não concordam com a Razão, com o conhecimento e com a ciência.

Corroboramos com o pensamento Lefebvreano. Tratando-se de interesses, quando o interesse individual se sobrepõe ao coletivo, certamente se refere aos interesses específicos de certos grupos dominantes, organizados sob as estratégias requintadas do atual estágio do capital, apesar de toda a negação produzida por esses esquemas de perpetuação de poder, dando-Ihes ares de harmonia, são qualquer coisa, menos uma sociedade de objetivos harmoniosos.

Marx (2010, p. 13), já refletia que harmonia nesse contexto não existe:

[...] O homem luta contra a natureza; [...] deve vencê-la e dominá-la, através do trabalho, da técnica e do conhecimento científico, e é assim que ele se transforma em si mesmo. Quem fala de contradição fala também em problemas a resolver, dificuldades e obstáculos - portanto, luta e ação - mas também na possibilidade de vitória, de passos à frente, de progresso.

Concordamos com Marx (2010, p. 14) de que o marxismo escapa do pessimismo definitivo e foge do otimismo fácil. A realidade encontra-se em base natural histórica com toda a lógica das contradições. Busca 
contínua tomada de consciência do mundo real, com presentes contradições, para soluções racionais a esses problemas. Evidente luta do homem contra a natureza e com todos os problemas decorrentes desse processo. Tal concepção emergiu com a sociedade moderna - com as indústrias e o proletariado industrial.

Do aparente estado fatalista das coisas, diante do conhecimento dos problemas apontados até aqui, poderemos propor/refletir/articular as reais tentativas para as mudanças necessárias.

Nesta Seção tentaremos encontrar algumas respostas a essas contradições. Refletir sobre o Trabalho e a Educação sob o contexto capitalista e a inserção da EJA nesse contexto.

Procurar entender o Trabalho no atual contexto capitalista brasileiro é a tentativa de desvendar todas as contradições existentes em suas bases históricas. Considerando que o capital não se alterou em sua estrutura, e sim, foram transformações das forças produtivas em decorrência de seu próprio processo histórico e emerge daí a busca pelo entendimento dessa contradição, baseando-nos no seu conhecimento central, bem como, o de sua sustenção.

Para o entendimento da base lógica de sustenção do atual capital é necessário ampliar o debate ao limite, do qual, possibilitará o entendimento aos mecanismos de constrangimentos que o sustenta e o perpetua.

No desvelamento das questões que se desenvolveram a partir do processo da pesquisa, percebemos ser importante circular pelas concepções de trabalho construídas no processo histórico pelas sociedades capitalistas ocidentais.

Perceber em que realidade social se constituiu tal conceito e como se arraigou em parcelas dessas sociedades trará elementos importantes às proposições e considerações desta pesquisa. 


\section{1 - O TRABALHO NAS RELAÇÕES DE PRODUÇÃO CAPITALISTA}

Percebemos que o trabalho sob o capital possui limitações bem definidas. Qualquer desvio nesse caminho é interceptado por sujeitos prontos e ações ajustadoras e corretivas. A manutenção nas relações do modo de produção no capital é mais que a força das leis institucionalizadas nos Estados Nacionais, elas são sociais.

Se o capital consegue convencer a "importância do trabalho" para vida humana, realiza tal feito sob a fetichização do seu uso, mascarando todo o seu processo de alienação ${ }^{15}$.

$\mathrm{Na}$ sustentação desse pensamento, resgatamos o conceito de trabalho na reflexão de Henri Lefebvre ${ }^{16}$, sob a produção do capital. Para tanto essa tarefa exige-nos análise das relações de produção das atuais sociedades, do conjunto de relações das coisas (objetos e produtos) que as define enquanto relações complexas e múltiplas.

Lefebvre (2006, p. 21-25) busca elucidar as relações de produção capitalistas ampliando o seu pensamento sobre a produção do espaço, no qual adiante, o revela enquanto espaço social. Não em um único espaço social, mas em vários espaços sociais. Da compreensão desse espaço e das relações sociais que dele implica, contém e dissimula, exorta que essa análise torna-se tão difícil a tal ponto de se aproximar a um paradoxo.

${ }^{15}$ O conceito de Alienação remete-nos a uma das categorias de análise do Capital. O trabalho no capitalismo tornou-se atividade de sofrimento. Fruto de uma deformação que se encontra na divisão social do trabalho, na apropriação privada das fontes de produção, no aparecimento das classes sociais, onde "alguns homens passaram a dispor de meios para explorar o trabalho dos outros; passaram a impor aos trabalhadores condições de trabalho que não eram livremente assumidas por estes" Desse processo introduziu-se um novo tipo de contradição no interior da comunidade humana, no interior do gênero humano (KONDER, 2006, p. 29-30).

16 Henri Lefebvre (1901-1991) foi um dos intelectuais franceses que mais atuou na divulgação do marxismo pelo mundo. Foi professor na Universidade de Paris-Nanterre. Realizou importantes contribuições nas áreas da sociologia, geografia, filosofia e crítica literária (LEFEBVRE, 2010, p. 4). 
O espaço social não é uma coisa entre as coisas, um produto qualquer entre os produtos; ele engloba as coisas produzidas, ele compreende suas relações em sua coexistência e sua simultaneidade: ordem [relativa] e/ou desordem [relativa] [...] O conceito de espaço social se desenvolve, portanto, ampliando-se (LEFEBVRE, 2006, p. 7; 13; 24).

Sob o esquema do pensamento Lefebvreano, o conceito de espaço social "se introduz no seio do conceito de produção e mesmo o invade". Engendrado por um movimento dialético muito específico "não revoga a relação 'produção-consumo' aplicada às coisas (os bens, as mercadorias, os objetos de troca), mas a modifica ampliando-a" (Lefebvre, 2006, p. 24).

Em Lefebvre (2006, p. 24) emergem os níveis de análise: as forças produtivas e seus componentes - natureza, trabalho, técnica, conhecimento; as estruturas - relações de propriedade; as superestruturas - as instituições e o próprio Estado. O procedimento

Dos níveis de análise em Lefebvre retivemos o Trabalho enquanto categoria que emergiu no processo de nossa busca à determinante nas quedas das matrículas da EJA pelo Brasil, entre 2000 a 2012.

Do conceito de trabalho segundo o espaço social, Lefebvre (2006, p.46) o considera como obra e produto: realização do "ser social", mas em conjunturas determinadas, o trabalho toma características de fetiche, automatizados, da coisa - mercadoria e dinheiro.

Aqui percebemos o que faz do trabalho mais do que ação de buscar dinheiro para a sobrevivência, é reconhecidamente valor social, construído historicamente através do sangue dos pais ancestrais da atual classe trabalhadora. Considerando esse peso e essa medida, poderemos refletir adiante sobre a Educação de Jovens e Adultos no contexto do Capital.

Para tanto ampliaremos nosso debate, adiante a análise somente poderá ser retida pela totalidade, pois a fragmentação na análise 
escamoteia a realidade e abre precedentes para o reducionismo simplista, como vimos na seção anterior.

É dessa noção que percebemos em Lefebvre (2006, p.24-25) as consequencias da análise fragmentada do espaço social, em cada parte destes níveis, torna-se "uma espécie de infinito atual".

[...] Os lugares não se justapõem somente no espaço social, em contraste com aqueles do espaço-natureza. Eles se interpõem; se compõem, eles se superpõem e às vezes se chocam. [...] 0 princípio da interpenetração e da superposição dos espaços sociais comporta uma preciosa indicação: cada fragmento de espaço retido pela análise não esconde uma relação social, mas uma multiplicidade que a análise revela (LEFEBVRE, 2006, p. 28).

Percebemos que as sociedades contemporâneas apropriam-se desse esquema fragmentado "das coisas" induzidas por um pensamento dominante de classe, com intencionalidades bem específicas. Dessa perspectiva, deduzimos que da atual situação de inércia e imobilismos nessas sociedades não conseguem reter o essencial para a análise, perceber o cerne dos seus problemas: a cotidianidade ${ }^{17}$.

Esta vida cotidiana produzida pelo capital abarca a todos, numa circularidade entontecedora. O tempo capturado para o trabalho é o reconhecidamente valorizado socialmente.

As demais ações humanas e da vida nesse espaço secundarizam-se (em alguns casos nem existem): o prazer, o lazer, a cultura embora reconhecidos espaços importantes, mas tratando-se de espaço para a classe trabalhadora toma-Ihe outro peso e outra medida, até de crime ou de morte, conforme o momento histórico que as constrói. "A classe operária afunda-se no quotidiano e por aí pode [ou poderia] negá-lo e transformá-lo. A burguesia, essa amolda, o quotidiano e julga escapar-se

${ }^{17}$ Referência à vida cotidiana extraída em Lefebvre (1969, p. 43-44) - caracteriza a sociedade em que vivemos engendrada pela cotidianidade - "o tempo capturado" pelo capital. 
dele por viver graças ao dinheiro um perpétuo 'domingo da vida' (LEFEBVRE, 1969, p. 58)".

É dessa percepção que em Lefebvre (2006, p. 35-41) emerge o espaço vivido, o espaço concebido e o espaço percebido. Do espaço vivido as relações estabelecem-se das diferenças ao modo de vida programada, as experiências da vida cotidiana. Do espaço concebido estabelecem-se os espaços da representação abstrata, do saber técnico, ideológico, do pensamento hierarquizado sustentado pelo capital e suas íntrínsecas necessidades. Do espaço percebido relaciona-se à prática espacial, sob a lógica da produção e reprodução social.

Todo o processo de trabalho que sustenta tais relações sociais no capital estabelecem-se sob a base das trocas, estas, nem sempre correspondem à mesma moeda, e quanto aos valores, evidenciam-se bem distintos. Desse quadro só é possível a perpetuação do capital através dos fragmentos que interceptam a análise. Como já vimos, estes ocultam contradições intrínsecas ao modo de produção do capital.

$\mathrm{Na}$ síntese desse pensamento Lefebvreano, refletido sob o movimento marxista, desmascara e desoculta a realidade escondida por traz da fragmentação. Essa fragmentação entra como ciência da "verdade", com as certezas "irrefutáveis" sustentadas pelo pensamento liberal, sustentado na ciência positiva e perpetua-se no senso comum.

Perguntamo-nos então o que se oculta, o que se mascara? O que tenta se ocultar é a verdade contida nas coisas e produtos, a fetichização. ${ }^{18}$ Esta, cumpre o papel de dourar as setas do mercado, ou

${ }^{18}$ À primeira vista, uma mercadoria parece uma coisa evidente, trivial. Porém em MARX a mercadoria se opõe à ideia de "valor de uso" das coisas, ou seja, o carácter místico da mercadoria não brota do seu valor de uso, objetiva-se sob uma ilusão naturalizada, revela aparência de igualdade, mas na verdade oculta sua essência de desigualdade. $\mathrm{O}$ fetiche emerge da fantasia/simbolismo sobre o objeto. Consiste no fato da mercadoria refletir para os homens os caracteres sociais do seu próprio trabalho como caracteres objetivos dos próprios produtos de trabalho, como qualidades naturais sociais dessas coisas, e por isso também a relação social dos produtores para com o trabalho 
melhor, do consumo. Desse processo, o trabalho social tornado mercadoria e os produtos fetichizados tornam-se mais "reais" que a vida real, no processo do consumo e da alienação ao trabalho. Na busca dessa realidade Marx necessitou abalar as certezas de sua época, precisou decompor o senso comum e a vida cotidiana.

O que vimos no crescimento da oferta do trabalho no Brasil não é mais do que um crescimento das forças produtivas, alavancadas sob a égide do capital. O trabalho para o capital, para a produção e reprodução das riquezas não oferecem mais do que o "dinheiro de circulação" aos trabalhadores, o que Ihes conferem acessos ao consumo; a riqueza ainda não está distribuída. "A riqueza real, que é o dinheiro" (MARX, 2010, p. 82-88) se concentra nas mãos da burguesia. Nesse pensamento, inferimos que o crescimento do trabalho (dos postos de trabalho) no Brasil contemporâneo constitui-se como crescimento das forças produtivas, portanto, com base ideológica fetichizante.

Na questão do crescimento da oferta de emprego analisado em parcelas e fragmentos pode mascarar em longo prazo os seus efeitos, uma situação perigosa, que historicamente pontuou-se em ciclos de crise violentas, das quais não trataremos longamente aqui, mas vale pontuar a questão central do nosso problema nas quedas das matrículas iniciais da EJA, enquanto problema social.

Para tal reflexão evocamos Lefebvre (2006, p. 18-20) que elucida sobre os períodos das certezas propagadas pelo racionalismo econômico, social e político da época de Marx nos quais muitos se felicitavam pelos "progressos" realizados. Porém Marx já alertava sobre essa ilusão, "os constestava mostrando que não se tratava senão de um crescimento de

total como uma relação social entre objetos existentes fora deles. Fonte: http://www.marxists.org/portugues/marx/1867/capital/livro1/index.htm\#i1,em 20/02/12. 
forças produtivas, das quais no processo, agravavam os problemas ditos "sociais" e "políticos" ao invés de resolvê-los".

Desse processo, convém observar que a análise fragmentada sobre a atual situação do crescimento da oferta de trabalho brasileiro, pode mascarar um perigo, onde o capitalismo recente e nos ciclos da sua história promoveu "fracassos retumbantes, degringoladas catastróficas" (LEFEBVRE, 2006, p. 48).

Entre tais forças produtivas constitui-se o crescimento da oferta de trabalho no Brasil. Contraditoriamente, a problemática do espaço nasce de um crescimento das forças produtivas. Dos resultados apontados na pesquisa, a diminuição das matrículas na EJA emerge do crescimento da oferta de trabalho, o que agrava o problema em outros níveis, a saber, a educação. Em especial, a Educação para os Jovens e Adultos

Trabalhadores. Nesse sentido, precisamos repensar o que queremos e pretendemos da Educação enquanto sociedade ou correremos o risco de retroceder às conquistas e avanços atualmente alcançados.

\section{2 - A EDUCAÇÃo PARA JOVENS E ADULTOS NO CONTEXTO DO CAPITAL}

No período em que atuamos enquanto professor das escolas públicas da zona Sul da cidade de São Paulo, as preocupações estavam sempre presentes, no caso do ensino da EJA, por mais que se pensasse em melhores metodologias de ensino para dar sentido às aulas, observava-se que dos problemas e das possibilidades de ação para resolvê-los, entre eles o das quedas nas matrículas e o esvaziamento das salas da EJA, muitas vezes não estavam na sala de aula ou na escola, mas estravazavam os muros da escola, para espaços maiores.

Faltavam os sentidos e percepções nos quais essa pesquisa propôsse a desenvolver. Numa proposição de pensar e repensar ações que 
pudessem colaborar na reversão desse quadro. Nesse caminho, devolver para/na escola essa reflexão, dadas as condições oferecidas pelo capital, ou não, repensar novas propostas para a melhoria no ensino e oferta de real oportunidade a esse aluno Jovem, Adulto e Trabalhador.

Percebemos que para os professores mais comprometidos com a EJA, suas apreensões são reveladas em seus relatos. Por isso, julgamos de tal importância dos resultados desta pesquisa, refletir sobre eles na escola, com o professor e com o aluno.

Dessa situação, vale pontuar interessante questão feita por um professor, suscitada no início do trabalho de campo na EM. "A": "Quero ver - resultado da sua pesquisa, se vai ser mais uma apontando os professores como culpados por tudo de ruim que acontece na escola". Quando tratamos de usar o termo apreensão pontuamos a fala do professor da EM. "A".

Como citamos no início deste trabalho, os problemas da EJA passam pela cidade de São Paulo, que representa substancial importância econômica para o Brasil, mas é somente uma parcela do capital que integra/compõe o capital brasileiro. Procuramos refletir nosso problema central na Geografia, por entender que sua ciência e seus pensadores contemporâneos há muito a têm como ciência reveladora dos problemas espaço-sociais.

A reflexão permitida pela ciência geográfica com seus conceitos e teorias sobre o espaço urbano, consideradas as dimensões e escalas de uma metrópole da dimensão de São Paulo, revelou os problemas apontados até aqui em termos nacionais.

No decorrer da pesquisa nos deparamos com os dados obtidos em campo que indicaram realidades e deixaram interrogações a esta reflexão. Porém na maioria dos levantamentos realizados está presente a necessidade do entendimento dialético na relação "espaço geométrico e espaço social", nos termos da concepção de Damiani (1999a) entendemos 
a Geografia como ciência e elemento de fundamentação nesses processos de possibilidades e de mudanças.

Observamos nessas transformações e possibilidades de tranformações da EJA a partir da própria abordagem geográfica, e que a todo tempo sustentou este trabalho revelando-se intrinsecamente nos fenômenos estudados.

Dessa proposição recortamos na entrevista do professor R. sobre o aluno:

[...] O aluno de EJA volta para a escola com uma série de expectativas, mas ele já tem toda uma vida estruturada e a escola não ocupa uma centralidade para ele. Tem uma expectativa muito grande com relação à escola, mas a centralidade é o trabalho é a subsistência, então, por exemplo, no primeiro empecilho se ele não tiver condição de que as expectativas que ele tem estão sendo supridas/idealizadas/contempladas ele desiste (Professor R.).

Dessa consideração do professor R., atribuímos o valor social do trabalho, secundarizando outras instâncias da vida. Do pensamento socialmente aceito, infere-se que a escola é importante, mas colocada sob a balança da sobrevivência, do valor social e da vida sob o capital, o seu valor relativiza-se. A vida do aluno Jovem e Adulto da EJA centraliza-se no trabalho.

Partindo da reflexão acima, avançamos nossa investigação em busca dos dados qualitativos que confirmassem tal hipótese: a desistência dos alunos da EJA pelo aumento da oferta de emprego. A questão da centralidade do trabalho na vida dos alunos da EJA manifestou-se além da entrevista com o Prof. R., também nos relatos dos alunos:

"Há 19 anos. Trabalhava não tinha tempo" (EMEF B, fl.60); "Passei 2 anos sem estudar por causa do trabalho" (EMEF B, fl. 56); "Uns 15 anos motivo de trabalho" (EMEF B, fl.58); "38 anos porque agora o mercado de trabalho precisa de atualização de estudos para se integrar ao trabalho" (EMEF B, fl. 45); " 1 mês foi o trabalho atrapalhou bastante" (EMEF B, fl.42); "20 anos, ouve vários motivos, mais o principal a necessidade de trabalhar (EMEF B, fl. 23. Grifo do Autor); "Desde 1965, comecei a trabalhar e daí não deu mais" (EMEF B, fl. 63); "Não estudava a muito tempo, 
porque onde trabalhava os patrões não deixavam (casa de família) (EMEF B, fl. 15); "Na verdade nunca quis parar de estudar fui obrigada para quando comecei a trabalhar" (EMEF A, fl. 65); "45 anos precisava trabalhar" (EMEF C, fl. 08).

Nadar contra a correnteza em muitos momentos históricos significou prisões e morte. Hoje, repensamos o quanto essa ação pode custar, talvez, não seja muito diferente de épocas passadas, considerando-se que a estrutura central do capital não sofreu alterações. Salvo considerações muito específicas, ainda hoje o ato de "não trabalhar", independente das circunstâncias ou em casos mais específicos, pode significar: ostracismo; autoculpa; perda do valor social, entre outros aspectos.

Lefebvre (1969, p. 26) questiona como os trabalhos parcelares podem ser objeto de liberdade.

[...] consiste em saber em que medida a soma de constrangimentos e determinismos [necessidades - trabalhos parcelares - conhecimentos fragmentários - determinismos biológicos, geográficos, econômicos, histórico-políticos, etc.] pode surgir como um "mundo" objeto de liberdade, perspectiva de uma obra mais alta dessa mesma liberdade.

Essa reflexão aprofunda-se segundo o grau de complexidade apresentado. A liberdade aqui se delimita, objetivamente, sob essas condições a observar. Dessas condições, a esse aluno da EJA não depende dele somente sua busca e a sua "vontade" pelo seu estudo escolar, posto o pensamento liberal dominante. Quando o aluno da EJA por seus "meios" tentar avançar seus estudos poderá, muitas vezes, "descobrir que afinal não dispõe dos meios" (LEFEBVRE, 1969, p. 24).

Nessa situação, o trabalho e a educação em perspectiva mais plena "se interpõem; se compõem se superpõem e às vezes se chocam" (LEFEBVRE, 2006, p. 38) com os interesses do capital, pois, para conciliar estes elementos contraditórios necessita-se de uma terceira dimensão: o tempo.

Ainda, segundo Lefebvre (2006) na natureza, o tempo se apreende no espaço, se inscreve no espaço. Dessa noção entendemos como o 
tempo para a vida tornou-se rareza, numa lógica perversa, quando para a vida, perde seu valor, é secundarizado. "O tempo desaparece no espaço social da modernidade. O tempo vivido perde forma e interesse social, exceto o tempo do trabalho. O espaço econômico depende do tempo" (p.37-38).

O tempo é capturado para a produção e reprodução capitalista. O tempo da/para a educação? Relativiza-se, conforme as mesmas necessidades de produção e reprodução do capital. Os constrangimentos cada vez mais elaborados cumprem o seu papel, realizam-se na quotidianidade.

A quotidianidade realiza-se sob muitas faces do fetiche. Nesse sentido o que é a "conquista" do trabalho? Para boa parte dos trabalhadores, talvez, o trabalho expressa-se em valor de salários, meios de aquisição de dinheiro para a sua sobrevivência, ou fetichizado, meios de "enriquecer-se".

O salário é o capital variável, que entra em cena como fator vivo da força de trabalho, o trabalho real (MARX, 2010, p. 52). O que se oculta nesse processo é que o trabalho pertence ao capital e não é objeto de negociação entre os empresários e os trabalhadores. É parte substancial para a aquisição da mais-valia ${ }^{19}$, ou seja, parte integrante que compõe o lucro do empresariado.

[...] O seu trabalho pertence ao capital, não é mais do que o valor de uso de mercadoria que ele, operário, vendeu e vendeu-a unicamente para se apropriar de dinheiro e, mediante este, de meios de subsistência (MARX, 2010, p. 81).

É importante uma breve discussão sobre esse aspecto, pois ainda precisaremos refletir sobre a totalidade do problema desta pesquisa.

19 "A função verdadeira, função específica do capital enquanto capital é, pois, a produção de valor excedentário e esta [...] não é mais do que produção do sobretrabalho, apropriação - no decurso do processo de produção real - de trabalho não pago, que se apresenta à vista e se objetiva como mais-valia." (MARX, 2010, p. 42-43) 
Com o crescimento das forças produtivas - a saber, da oferta do trabalho - a lógica para o crescimento do valor dos salários não se realiza pelas mesmas regras. O controle para evitar os altos salários e mantê-los estritamente nos patamares da sobrevivência básica registrou-se nos anais da história da criação do proletariado, na acumulação primitiva que segundo Marx (2009, p. 52-53) tal ação, desejo ou intenção tornou-se "criminalidade" com punições severas.

Como vimos no item anterior, salário não é riqueza, senão meio de circulação de dinheiro; entre trocas de salários/mercadorias, constitue-se em consumo.

O proletário, ou assalariado, no plano capitalista obtém dinheiro, em forma de salários, através do trabalho a que está subjugado. ${ }^{20} \mathrm{~A}$ subjugação deste proletário é um ato que vem antes mesmo do trabalho ou da educação (MARX; ENGELS, 1999, p. 20).

Os alunos da EJA deixaram de estudar para trabalhar. O capital fetichiza o trabalho, como também a educação em discursos e representações sob a lógica liberal, conforme as necessidades intrínsecas do capital. Perguntamo-nos, então, como o trabalho se apresenta enquanto problema? Se analisado isoladamente nenhum, porém na totalidade há muito a se refletir.

Quando procuramos entender sobre a realidade das desistências nos cursos de EJA e da importância da escola na vida dos alunos, percebemos mais um equívoco de nossa parte: o prisma de observação deveria ser invertido - a questão deveria ser: Qual a importância da educação dos Jovens e Adultos para o modo de produção capitalista?

${ }^{20}$ Subjugado - subjugado adj. (part. de subjugar) 1 Que se subjugou; submetido pela força; domado, dominado. 2 Que vive debaixo de jugo; conquistado. Fonte: http://www.dicio.com.br/subjugado/. Considerando tais termos do dicionário, ampliamos enquanto meios de constrangimentos intrínsecos do capital. 
Quando recorremos a textos, pesquisas e discursos oficiais sobre as derrocadas da EJA, muitos destes nos remetiam aos fracassos do professor, do aluno, dos sistemas de organização, das políticas públicas, da formação docente, incompatibilidade de horários entre trabalho/escola, entre tantos outros, como citamos anteriormente, concordamos, contextualizados a seu tempo/espaço históricos. Porém, não se sustentavam no processo histórico em que desenvolvemos essa pesquisa. Também escamoteavam os motivos dessa queda nas matrículas considerando os aspectos da fragmentação na exposição dos motivos em cada um deles. Abaixo trouxemos um exemplo das inquietações que foram reveladas.

O IBGE informa:

[...] Dentre os motivos para a não conclusão do curso de educação de jovens e adultos apontados por aquelas pessoas que frequentaram anteriormente, os principais eram: o horário das aulas não era compatível com o horário de trabalho ou de procurar trabalho $(27,9 \%)$; o horário das aulas não era compatível com o horário dos afazeres domésticos (13,6\%); tinha dificuldade de acompanhar o curso $(13,6 \%)$; não havia curso próximo à residência $(5,5 \%)$; não havia curso próximo ao local de trabalho $(1,1 \%)$; não teve interesse em fazer o curso $(15,6 \%)$; não conseguiu vaga $(0,7 \%)$; e outro motivo $(22,0 \%)$. O gráfico a seguir ilustra as diferenças regionais por alguns dos motivos apontados como responsáveis pela não conclusão do curso de educação de jovens e adultos. No Sudeste, o motivo o horário das aulas não era compatível com o horário de trabalho ou de procurar trabalho registrou $33,5 \%$, enquanto, no Nordeste, esse motivo atingiu 20,2\% (IBGE, 2009, p. 35).

Essas informaçãoes fragmentadas não foram suficientes para o melhor entendimento do objeto da pesquisa. Houve necessidade de compará-las com os dados qualitativos. Tomando-se por base que no ano de 2007, segundo a nossa Tabela 3 B (APÊNDICE D, p. 153).

Segundo a Tabela 3B (APÊNDICE D, p. 153) o início das quedas nas matrículas a EJA no território nacional deram-se, predominantemente, a partir de 2007. Os dados do IBGE (2009) sinalizavam a tendência da desistência na EJA devido às dificuldades do tempo do trabalho e do 
tempo para a educação, outros motivos não determinavam as desistências.

O Professor R. coordenador pedagógico de uma boa escola da zona Sul ao relacionar a evasão/queda das matrículas nas escolas públicas da zona Sul de São Paulo coloca que os motivos de desistência nas escolas públicas são similares aos da escola privada onde trabalha.

[...] Eu percebo isso tanto aqui quanto, por exemplo, sou coordenador de um curso de EJA numa escola particular com o mesmo público, a escola tem todos os recursos, lá não existe dispensa de aula por motivo nenhum. O aluno vai sabendo que vai ter aula da primeira à última aula. [...] Eles gostam da escola, eles querem escola, mas não é a centralidade no sentido de que ele precise da escola para organizar a sua vida. A vida dele já tá de alguma forma organizada, isso eu percebo na rede pública, na rede estadual e a gente conversa com outros/outras regiões e se percebe a mesma coisa, a desistência, a evasão... (Professor R., Dez.,2012).

Para entender essa questão retomamos pensamento de Lefebvre (2006) sobre o crescimento das forças produtivas. Considera mais exato separar-se de "crescimento" em geral, pois entende como abstração carregada de ideologias. O que dificulta o entendimento dialético nesse processo é o espaço recortado/fragmentado,

[...] a tendência ideologicamente dominante reparte, segundo a divisão social do trabalho social, as partes e parcelas do espaço. [...] cai-se na armadilha do espaço "em si" e como tal: da espacialidade, do fetichismo do espaço. Como anteriormente nas armadilhas da troca, do fetichismo da mercadoria e da "coisa" considerada isoladamente, tomada "em si" (LEFEBVRE, 2006, p. 30).

Os cursos da EJA atravessados por mecanismos de diversos constrangimentos, como as políticas públicas, recebem determinações alheias aos grupos internos, a exemplo do financiamento não condizente com as necessidades do curso. 
O trabalho e a educação também são atravessados de maneira perversa nesse processo, enquanto parte das forças produtivas no modo de produção capitalista, ora avançam, ora retrocedem, conforme os movimentos específicos construídos historicamente.

É sob essa lógica perversa e contraditória que Lefebvre esclarece que as "forças produtivas e técnicas permitem intervir a todos os níveis de espaço: o local, regional, nacional, planetário. Modifica-se o espaço inteiro (geográfico e histórico) sem revogar suas implicações, os pontos iniciais, os primeiros domícilios e núcleos, os lugares" (2006, p. 30).

Revelam-se nesse processo contradições específicas. Retoma-se a contradição entre a propriedade privada dos meios de produção e o caráter social das forças produtivas. Os cursos de EJA têm seguido tais condições pré-existentes. Ora avançam para suprir as específicas necessidades da mão de obra, ora retrocedem para manter "seguros" alguns caracteres, como os níveis controlados de salários, das relações "oferta-procura" ou "emprego-desemprego", entre outras.

No espaço urbano em que o aluno da EJA habita percebe-se a fragmentação social distribuída em suas localidades e uma sociedade impotente aos problemas sociais abrangentes e que não apontam para soluções porque não dizem especificamente àquela realidade, bem como ainda impõem uma convivência segregada na cidade para a população que nela mora.

O aluno da EJA estuda e trabalha sob violências veladas e muitas vezes não veladas. Situações essas sustentadas pela alienação social que o impossibilita de construir a própria cidadania. É neste pensamento que nos apropriamos da reflexão de Damiani (1999a) sobre o infracidadão:

[...] aquele que não se reconhece em sua obra e vivência, de forma totalmente alienada, suas relações humanas, sendo seu espaço vivido reduzido ao espaço geométrico, onde essa restrição da vivência não atinge somente aos mais pobres, embora os alcance preferencialmente (DAMIANI, 1999a, p.52). 
A cidadania que buscamos para o aluno da EJA constitui-se nas bases da concepção plena em que Damiani (1999a, p. 50) revela, "envolve o sentido que se tem do lugar e do espaço, já que se trata de materialização das relações de todas as ordens, próximas ou distantes".

A EJA emerge como uma das setas indicadoras na construção do entendimento e do pertencimento à cidadania dos sujeitos não somente na cidade de São Paulo, mas nacionalmente, que dela buscam suas realizações plenas de efetivação. Não perceber o aluno da EJA enquanto sujeito ativo nesse processo é perpetuar a alienação, o ensino distante, desconectado, descomprometido e abarcado na fragmentação social, não garantindo-Ihe real apropriação do espaço do cidadão, efetivamente, impedindo-o de ser cidadão. Como evoca Damiani "Um espaço realiza-se como social quando é, de fato, apropriado" (1999a, p. 51).

Dessa noção de apropriação é que consideramos o uso do termo e do conceito de "possibilidades". A relação do trabalho e da Educação de Jovens e Adultos no contexto do atual modo de produção e reprodução ainda necessita de breve exame.

A difícil tarefa de buscar a realidade decorre do fato de estarmos "diante de mudanças e acontecimentos que desafiam os parâmetros estabelecidos de análise da crítica social, para além das denúncias das misérias do mundo ou do lamento nostálgico do que poderia ter sido e não foi." (TELLES, 2006, p. 43-45).

Tratando-se de Educação, e nesse contexto, de Educação para Jovens e Adultos há de se observar e trazer a debate o que a sociedade brasileira idealiza como educação e qual o legado prevalecerá às futuras gerações, educação para o capital ou educação para a vida. 


\section{3 - A EDUCAÇÃo PARA JOVENS E ADULTOS E O CAMINHO Às TRANSFORMAÇÕES NO CAPITALISMO CONTEMPORÂNEO DO BRASIL.}

[...] Eu considero estas perguntas que eu me faço todas óbvias. Só que, a propósito do óbvio, eu tenho dito e redito que uma das coisas que descobri [...] é que nem sempre o óbvio é tão óbvio quanto a gente pensa que ele é. $E$, às vezes, quando a gente se aproxima da obviedade e toma a obviedade na mão, e dá uma rachadura na obviedade, e tenta entrar na obviedade para vê-la desde dentro e de dentro e por dentro [...] é que a gente vê mesmo que nem sempre o óbvio é tão óbvio (FREIRE, 1988, p. 92).

Ao iniciar esta seção muitos aspectos da pesquisa já estavam elucidados, outros não. Os resultados que emergiram da pesquisa trouxeram novas e outras questões. O trecho acima de Paulo Freire tem a ver com esse momento de reflexão.

Tratar sobre o trabalho, educação e das contradições, enquanto categorias que emergiram no processo de investigação, na perspectiva do capital entender o problema da pesquisa, considerada a "realidade" dos cursos de EJA que apreendíamos antes desta pesquisa, ante o que neste momento se apresenta e apreendemos, remeteu-nos a esse pensamento Freireano.

A pesquisa tentou analisar o problema das quedas nos índices de matrículas nos cursos de EJA numa abordagem distante das que nos rodeavam na prática do trabalho e na vivência cotidiana. A proposta foi abordar o problema "desde dentro, de dentro e por dentro" essa colocação, talvez, expresse o que foi o sentido da totalidade buscada.

Nesse momento buscamos entender em quais aspectos poderemos abrir debate sobre o tratado até aqui e, que afastados da retórica, tornem proposições em ações na tentativa das transformações a esses cursos tão singulares. 
Entendemos transformações enquanto construção de ações rumo a mudanças. Entendemos que a Educação não pode se limitar ao ensino escolar dos compêndios. Juntos, os alunos e seus professores poderão compreender como se apresenta a vida real na relação intrínseca entre eles e sobre o espaço social que os envolve.

Aprender e ensinar fazem parte da existência humana, histórica e social, como dela fazem parte a criação, a invenção, a linguagem, o amor, o ódio, o espanto, o medo, o desejo, a atração pelo risco, a fé, a dúvida, a curiosidade, a arte, a magia, a ciência, a tecnologia. E ensinar e aprender cortando todas estas atividades humanas (FREIRE, 2001, p.19).

Entender as formas de apropriação a que necessitam rumo à cidadania também é desejável e fundamental. A escola necessita ser algo mais do que servir ao capital. Entendemos que a escola pode ser o centro mediador da passagem da prática para abstração teórica e dessa para uma prática consciente.

Com a promulgação da LDB 9394/96 - Lei de Diretrizes e Base da Educação Nacional, os dicursos apregoavam, que progressivamente, com a efetivação dessa nova base educacional nacional efetivariam-se as garantias necessárias para o devido atendimento educacional, bem como, a garantia no desenvolvimento do processo de democratização educacional no país.

Essa crença levou muitos gestores, a antecipadamente, divulgarem quase como certa a diminuição das matrículas nos cursos noturnos por extinção da demanda e, de acordo com as previsões, a diminuição do número de salas de aula para EJA. Alardeavam que em até dez anos a suplência iria desaparecer.

Percebemos que a linearidade do discurso liberal deparou-se ante à vida real. A EJA de fato hoje despencou em números de matrículas, mas não pela oportunização/atendimento/conclusão da etapa inicial de escolarização dos alunos do Ensino Fundamental Regular ou pelo atendimento aos alunos da EJA. 
Despencaram suas matrículas devido ao crescimento das forças produtivas, impulsionadas pelo momento histórico-econômico brasileiro de oferta expansiva de empregos e trabalhos.

De acordo com os dados do IBGE-PNAD de 2011, apresentados no Gráfico 9 desta dissertação, os setores da Construção Civil, Serviços e Comércio alavancaram a evolução do contingente de ocupados entre o período de 2009-2011.

No caso dos alunos das escolas selecionadas para a pesquisa, na zona Sul da cidade de São Paulo, grande contingente do trabalho oferecido naquela localidade, concentrou-se no comércio (pequenas lojas do bairro, lojas de Shopping ou supermercados).

O DIEESE em 2009 divulgou em boletim o perfil do aluno jovem comerciário, sobre o seu trabalho e estudo. Informa que em 2008, aproximadamente, $25 \%$ do total de ocupados neste setor tinha entre $16 \mathrm{e}$ 24 anos de idade, baseado nos dados do sistema Pesquisa de Emprego e Desemprego - Sistema PED.

Declara que o comércio sempre foi considerado a porta de entrada para o mercado de trabalho, como um dos principais setores econômicos em termos de absorção da população jovem brasileira. Desta colocação nos forneceu importante dado na análise:

As informações apuradas pelo Sistema PED têm revelado a importância da atividade comercial para a força de trabalho jovem das regiões metropolitanas. É nesse segmento que existem maiores facilidades para o jovem obter um posto de trabalho, em comparação com os demais setores. Em 2008, a maior parcela da população dos ocupados no comércio nas regiões pesquisadas tinha entre 16 e 24 anos: Belo Horizonte, 27,3\%; Distrito Federal, 26,4\%; São Paulo, 26,2\%; Porto Alegre 25,2\% e, mesmo que em proporção menor, em Salvador $22,6 \%$ e Recife $19,1 \%$ (DIEESE, 2009, p. 1). 
A publicação mensal DIEESE (2009, p. 2-4) revela ainda que a organização do setor do comércio incorpora desde grandes redes nacionais e internacionais até uma imensa quantidade de micro e pequenos estabelecimentos familiares, dos quais, demanda grande número de trabalhadores, o que explica em grande parte, a expressiva presença dos jovens no comércio.

Também revela que, de maneira geral, a forma mais comum de ocupação no comércio é a contratação padrão, ou seja, com carteira de trabalho assinada. No caso dos jovens, constata-se para estes, há maior proporção nos contratos típicos do assalariamento, ou seja, com carteiras de trabalho assinadas, com relação aos registros em carteira verificados entre os adultos.

Na pesquisa do DIEESE surgiu um segundo grupo de jovens, o grupo de jovens no setor do comércio que se subordinam ao trabalho sem carteiras assinadas. Estes estão entre os assalariados terceirizados e autônomos que trabalham para alguma empresa. Os percentuais nesse grupo ultrapassaram os $30 \%$ dos jovens no comércio sem carteiras assinadas.

Quanto ao tipo de trabalho oferecido a esses jovens, o boletim descreve que, a esse trabalhador, um fator de atração que os impulsiona ao trabalho no comércio realiza-se na possibilidade de sua inserção em inúmeras funções não especializadas e de baixa remuneração que, em geral, não requerem qualificação ou experiência anterior.

Ainda, outro elemento a ser considerado, segundo o boletim, é a associação entre os produtos comercializados e valores compartilhados e/ou relacionados aos jovens, como vitalidade, energia e beleza. A essa situação o Boletim caracteriza como mercantilização da juventude.

Desse contexto, ao perceber todo o mecanismo de apropriação do trabalho juvenil pelo mercado, resgatamos o pensamento de Lefebvre 
(2006, p. 37), ao qual, julgamos como adequado à seguinte análise: "o capitalismo absorveu o espaço inteiro para utilizá-lo".

Nesse processo entendemos que o jovem brasileiro ficou submetido a um "processo circular de dependências das coisas" e, como consequência, não continuou ou retardou sua escolaridade, dispôs sua força de trabalho às necessidades de mercado e tornou-se parte intrínseca como sujeito de circulação de mercadorias fetichizadas. O trabalho oferecido a estes Jovens e Adultos no comércio são aqueles de menor remuneração, precarizados em muitas fases do processo.

Considerando que as bases estruturais do capital não foram alteradas (Mészáros, 2008; Lefebvre, 2006; MARX, 2010), inferimos que nos outros setores econômicos, como, construção civil, serviços, indústria ou até mesmo o serviços domésticos, os processos na forma de apropriação da mão-de-obra juvenil não seguem de maneira diferenciada.

Sobre essa questão observa-se o gráfico abaixo:

Gráfico 10

Proporção de jovens ocupados de 16 a 24 anos, segundo o setor de atividade econômica Regiões Metropolitanas e Distrito Federal - 2008

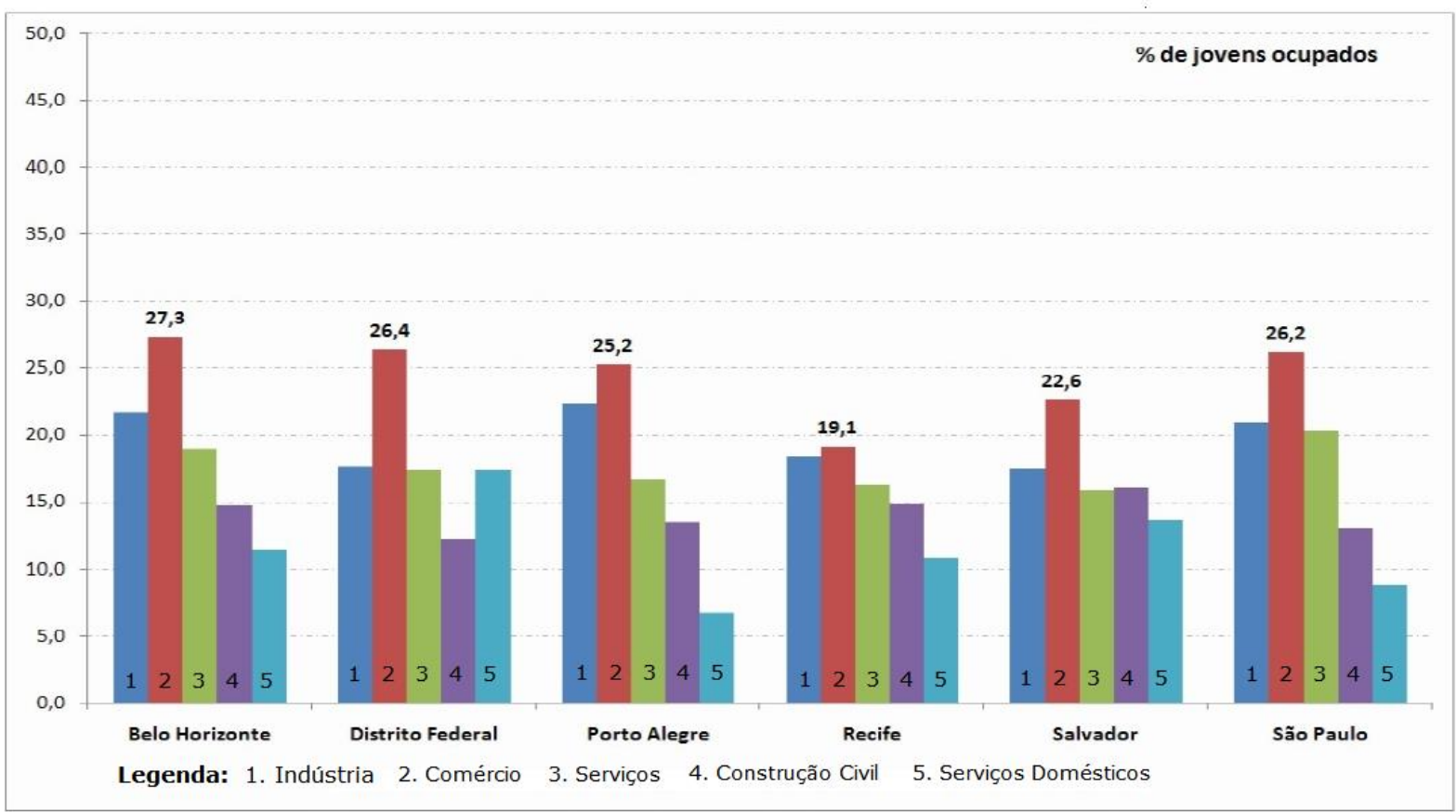

Fonte: DIEESE/SEADE/MTE - FAT e parceiros regionais. Pesquisa de Emprego e Desemprego - PED Adapatação: SOUZA, M.R., 2012. 
O Boletim também informou que para considerável parcela dos jovens comerciários o trabalho é importante contribuição na manutenção na renda das suas famílias. Em mais de $60 \%$ dos casos estudados, os jovens ocupavam a posição de filhos nos lares pesquisados, mas o que chamou a atenção nesse estudo emergiu nos índices de jovens que se declararam chefes de domicílios: no Distrito Federal 13\%; Porto Alegre 12,7\%; Recife 12,9\% e em São Paulo 11,1\%.

Ainda segundo o Boletim do DIEESE, a esses jovens são oferecidos os salários mais baixos e trabalho precário, considerando o cenário com que estes trabalhos são oferecidos. Exemplifica a remuneração dos jovens no comércio, a qual se manteve no ano de 2008 no patamar mais baixo dos salários pagos no setor, variando entre $R \$ 429$ (no Recife) e $R \$ 653$ (em São Paulo), rendimento correspondente a menos do que $70 \%$ daquele auferido pelos adultos com mais de 25 anos.

Sobre as complexas situações que tornam possível perceber a gravidade e a profundidade do problema do emprego no Brasil, encontramos em Pochmann (2007, p. 198) sustentação ao nosso pensamento:

[...] seu enfrentamento, em novas bases, é urgente e inadiável, uma vez que suas causas se encontram associadas às tendências estruturais que levaram à ampliação do excedente de mão-de-obra [...] e contenção das fontes de demanda de trabalhadores [...] da retomada sustentada do crescimento econômico e da reformulação da inserção do país na globalização - que representam a necessidade de reconfiguração do capitalismo brasileiro [...] especialmente num momento em que crescem novas modalidades ocupacionais, cada vez mais heterogêneas e menos centradas no assalariamento.

Com base nos dados apresentados, inferimos também que a circularidade histórica nos mecanismos de disposição de mão-de-obra para a manutenção das necessidades imediatas do capital se mantêm na atual conjuntura brasileira. O aumento das forças produtivas nada mais é, no atual caso brasileiro, do que a expansão da classe trabalhadora aos 
trabalhos precarizados. Dessa noção é que se torna urgente repensar sobre a estrutura em que se estabelecem as bases capitalistas brasileiras, pois, o prolongamento dessa situação, no limite, acirra as desigualdades sociais.

Segundo o Boletim (2009, p. 4-5) quando passamos para análise da escolarização e o tempo de permanência no posto de trabalho destes jovens, a comparação da remuneração dos mais jovens segue em desvantagem. No setor do comércio o que aparenta ser mais relevante é a experiência, associada à idade e o tempo de trabalho.

Os dados apresentados em 2008 demonstram que $70 \%$ da juventude no comércio estavam longe da sala de aula em todas as regiões metropolitanas analisadas. Entre os fatores que contribuem para essa realidade, segundo boletim, estão elevadas cargas de horas de trabalho.

A falta de qualificação do jovem comerciário implica na manutenção dos baixos níveis de rendimentos e compromete sua trajetória profissional. O Boletim conclui que o jovem comerciário enfrenta extrema dificuldade para prosseguir seus estudos ou retomá-los após a entrada no setor.

A partir da reflexão desse pensamento percebemos o caminho no direcionamento à realidade sobre a redução do número nas matrículas da EJA não somente na cidade de São Paulo, mas nacionalmente.

Da busca desta pesquisa em desvelar a realidade sobre a referência liberal rumo à extinção da EJA, a comprovação dos resultados trazidos neste trabalho emergiu de fontes diferenciadas e convergiram-se na análise.

Agora se trata de revelar nesta seção a questão elaborada no ítem anterior: Qual a importância da Educação dos Jovens e Adultos para o capital? 
Direito à educação na concepção do capital vincula-se em subjugarse aos desígnios do capital. Acima ou abaixo dessa perspectiva incorre-se, historicamente, a certa criminalidade. O direito à educação tem sido vinculado a obrigatoriedades diversas. A ideia das obrigatoriedades em educação não é nova. Segundo Mészáros (2008) John Locke ${ }^{21}$ já determinava a obrigatoriedade da escola para os pobres como maneira de controle e disciplina, enquanto preparo para o trabalho:

[...] que se criem escolas profissionalizantes em todas as paróquias, as quais os filhos de todos, na medida das necessidades da paróquia, entre quatro e treze anos de idade... devem ser obrigados a frequentar [...] (MÉSZÁROS, 2008, p. 42).

Desta situação, o contraditório estabelece-se entre se permitir reformas ao currículo, enquanto questão de poder, mas também proclamá-lo enquanto direito, por vincular ao "direito a que todo o cidadão tem de ser educado e de apreender os conhecimentos produzidos pelo conjunto da sociedade ao longo dos tempos" (OLIVEIRA, 2009, p. 50).

É claro que as instituições de educação passaram por transformações no decorrer do tempo devido a "determinações reprodutivas em mutação do capital". Atualmente, o abrandamento de algumas formas de disciplinamento escolar não se dá por conta de uma "consciência elevada" do pensamento burguês, a "brutalidade e a violência [...] foram abandonadas não devido a considerações humanitárias" e sim porque no processo das transformações da produção "revelou-se um desperdício econômico, ou era, no mínimo, supérfluas" mantê-las (Mészáros, 2008, p.43).

${ }^{21}$ John Locke (Wrington, 29 de agosto de 1632 - Harlow, 28 de outubro de 1704) foi um filósofo inglês e ideólogo do liberalismo, sendo considerado o principal representante do empirismo britânico e um dos principais teóricos do contrato social. Fonte: http://pt.wikipedia.org/wiki/John_Locke, em 20/04/2013. 
Apesar das transformações na Educação no curso do tempo, a lógica do capital permaneceu intata. Dessa proposição contraditória é formada e perpetuada a escola atual, sob um currículo que expressa os valores e interesses dominantes.

Oliveira (2009) reflete nos atuais discursos, o que corrobora socialmente aceito entre nossas sociedades, invertendo-se assim a lógica

[...] tendo em vista um mercado de trabalho cambiante e instável, que demanda alterações permanentes na formação dos trabalhadores e consumidores. [...] acarretando maior individualização e responsabilização dos sujeitos quanto ao sucesso ou o fracasso na trajetória escolar e profissional (OLIVEIRA, 2009, p. 51).

Esse discurso nos dá bem a medida de como anda a inversão da lógica no capital na atualidade, bem como, o quanto o trabalhador está subjugado nesse sistema, porém, de diferentes e novas formas. Essas não se encontram em leis declaradas e explícitas como na Inglaterra de Henrique VIII (1491-1547), mas ideologicamente dominante irradia-se por toda a sociedade sob alguns constrangimentos.

Ao trabalhador imputa-Ihe a exclusividade e responsabilidade ao seu sucesso ou ao seu fracasso, do âmbito escolar ao âmbito profissional, das quais, não são tão novas formas de constrangimentos assim. Desde a acumulação primitiva os destinos dos trabalhadores estão subjugados ao dispor do capital. Essa situação hoje é mantida na essência, as formas de constrangimentos foram modificadas, conforme as mudanças nas forças produtivas.

Segundo Mészáros (2008, p. 38-39) a legislação em vigor no reinado de Henrique VIII tratava os trabalhadores como criminosos voluntários, enquanto supunha que dependesse somente deles a vontade de trabalhar, ou não. Imputavam-Ihes nesse sentido a responsabilidade da vagabundagem. 
As relações com os trabalhadores ainda foi mantida até que a "própria mudança das condições de produção modificasse a necessidade de uma força de trabalho, ampliada sob as condições expansionistas da revolução industrial".

Segundo Mészáros (2008), as instituições formais de educação são uma parte importante no sistema global de internalização. Ela não consolida o sistema do capital. É vital observar nessa proposta liberal de reformas que se mantenham "intatas às determinações estruturais fundamentais da sociedade como um todo, em conformidade com as exigências inalteráveis da lógica global" (p. 42-45, grifo do autor).

Dessa reflexão, no caso da educação no Brasil, notamos que os processos de dominação/subordinação do econômico sobre todos os outros espaços não se pronunciaram diferentemente de outros países capitalistas, salvas as especificidades na formação histórica de cada um deles.

Mészáros (2008, p. 15) contribuiu, significativamente, na elucidação da questão: Educação para que, para quem? Nesta obra, evidencia-se o problema da educação a interesses muito específicos, os da burguesia e sua perpetuação, como regra geral.

Apesar deste desalentador e fatalista cenário trazido pela hegemonia do capital, propomos elevar a discussão em perspectiva das possibilidades, da reflexão que até aqui fizemos, buscar as saídas para combater a contradição do capital. Não enquanto fórmula ou panaceia aos males na EJA, longe dessa pretensão.

Percebemos a necessidade de elevar a participação dos sujeitos ativos para/nos processos de transformações à Educação de Jovens e Adultos. Ouvir mais; saber escutar (FREIRE, 2002, p. 127). Ser ouvido numa democracia como a nossa que ainda não legou aos seus cidadãos as formas plenas e reais de apropriação do espaço é ainda tarefa urgente. 
Penso que ainda não aprendemos a ouvir os alunos nas escolas, cumprimos o papel ideologicamente dominante, à risca, fazendo do aluno "receptáculo passivo" (LEFEBVRE, 2006, p. 30) e, em seguida, somos vitimados pelo mesmo processo. Tal ato implica em ocultar todas as relações sociais no espaço escola, o que implica na manutenção da contradição e perpetuação das forças vigentes.

Entendemos que essa é a base dessa contradição, o cerne do problema, do qual Lefebvre (2006) acusa aprisionar o intelecto e a tentar impedir o rompimento das cercas impostas ideologicamente.

Mészáros (2008, p. 59) afirma que o capital não consegue exercer suas funções sociais metabólicas de outra maneira senão "sob as condições de uma desumanizante alienação e de uma subversão fetichista do real estado das coisas dentro da consciência".

Das contradições que se apresentam no mundo da Educação, tendo como centralidade o mundo do trabalho, sustentadas por todo o processo de produção e reprodução do capital por entender que, em parte, foi desvelado o problema: "a questão se torna tanto 'inteligível como superável' a partir da raiz de todas as variedades de alienação historicamente reveladas alienação do trabalho: um processo de autoalienação escravizante" (MÉSZÁROS, 2008, p. 60).

É desse conhecimento que Mészáros (2008, p. 60-61) aponta a possibilidade de superar a alienação, através da mudança de perspectiva do próprio trabalho. Propõe uma reestruturação radical das condições de nossa existência e "de toda a nossa maneira de ser." Tal proposta advém da tarefa de "superar a alienação por meio de um metabolismo reprodutivo social dos produtores livremente associados", porém adverte que não se trata de "ser apenas uma questão da negação" da situação anterior, pois a história já mostrou recentemente o quanto o poder tende a regressar às práticas do status quo ante. 
É a partir desse entendimento que, segundo Mészáros (2008, p. 62), a Educação desempenha um importante papel e dessa mudança precisase observar atentamente algumas fases. $\mathrm{Na}$ fase inicial dessa transformação manter sob controle o estado político hostil que se opõe a esta mudança, para em seguida afirmar a negação radical de toda a estrutura de comando político do sistema estabelecido, evidenciando sua "inevitável negatividade predominante".

Nessa fase é importante ter clareza que essa negação só será adequada se orientada a todo o tempo e sem perder o foco pelo alvo global da transformação social a que se pretende, tal cuidado atuaria "como uma bússola para toda a caminhada".

É desse ponto que emerge uma educação de importância vital no processo. Uma educação que rompa com a internalização predominante (no caso, a burguesa) - é o processo denominado "contra internalização" ou contra consciência que "exige a participação de uma visão geral, concreta e abrangente de uma forma radicalmente diferente de gerir as funções globais de decisão da sociedade." Diferentemente da atual conjuntura que impõe uma expropriação aos indivíduos, "por meio de políticas como uma forma de alienação por excelência" (MÉSZÁROS, 2008, p. 63-65) da ordem burguesa.

Entendemos que a Educação vinculada ao modo de produção, em outras propostas de produção no decorrer do século $\mathrm{XX}$, mostraram que alguns discursos e práticas promovidos por transformações na recente história da humanidade, apropriando-se da total negação ao capital, no alto da crítica, o contraditório estabeleceu-se como antes das transformações, porém de maneiras diferentes.

Alguns revolucionários não somente mantiveram a base da opressão anterior, como estenderam os constrangimentos sociais e aceleraram a destruição das forças produtivas por eles sustentadas. Tornaram-se mais 
carrascos para o povo do que seus antigos carrascos. Formaram uma elite "burocrática" (TROTSKY, 2008).

A negação ao capital deve sustentar-se em bases concretas, sob a apropriação da realidade social construída por sujeitos conscientes da sua realidade. Movimento sustentado com base em uma Educação emancipadora de compreensão da vida, considerada a totalidade na natureza. Desarraigando-se do modo de produção atualmente estabelecido, o que Mészáros (2008, p. 65) caracteriza como automudança consciente. 


\section{CONSIDERAÇÕES FINAIS}

Esta dissertação teve, inicialmente, como temática central investigar as causas das quedas nas matrículas iniciais e o esvaziamento das salas de aula nos cursos de Educação para Jovens e Adultos nas escolas municipais da zona Sul na cidade de São Paulo. O objeto de estudo se concentrou em três escolas - EM. Marina Melander Coutinho, EM. Paulo Setúbal e EM. DR. Miguel Vieira Ferreira. Todas pertencentes à Diretoria Regional de Educação da Capela do Socorro.

As escolas pesquisadas colaboraram para o entendimento dos problemas em escala local. A situação de redução nas matrículas nas unidades escolares pesquisadas - entre 2007 e 2012 tiveram condicionantes muito específicas que contribuíram de certa forma para o esvaziamento das salas de aula naquelas escolas, mas a redução mais significativa nas matrículas ocorreu na EM. "B", dada a mobilidade nas matrículas entre essas escolas, impulsionada pelas campanhas realizadas para o aumento das matrículas e pela concorrência por alunos, resultante dessa situação.

Destas condicionantes, apontamos os resultados que surgiram em nossas primeiras incursões nas três escolas selecionadas. A mobilidade dos alunos da EJA entre as três escolas selecionadas; As mudanças urbanas no entorno das escolas, com a construção do Complexo Viário Jurubatuba e das estações de trens metropolitanos: Autódromo; Interlagos e Grajaú; A sazonalidade do trabalho dos alunos da EJA naquelas unidades escolares e certa mobilidade nos seus empregos. A esta terceira condicionante, é necessário o registro de que atuavam antes mesmo de se apresentarem os aumentos dos índices nas quedas das matrículas da EJA no período estudado. 
Essas condicionantes não sustentavam nossas hipóteses provisórias quando ampliávamos à observação para a cidade de São Paulo.

Percebemos no avanço da pesquisa que o conhecimento das questões locais não era suficiente para determinar o não visível, que extrapolava os muros da escola e mesmo os gabinetes educacionais, assim a cidade de São Paulo não respondia à questão central da pesquisa.

$\mathrm{Na}$ sequencia, percorremos metodologicamente por longo processo de investigação científica direcionados em Laurence Bardin e ampliamos mais uma vez o campo de observação. Sob todas as variáveis, cálculos e dados, constatou-se crescente queda nos índices de matrícula inicial na EJA em todo o Brasil.

Dessa constatação de quedas nas matrículas iniciais e o esvaziamento das salas de aula na EJA, partimos para a tentativa de entender o problema ampliando nossa observação, sob as variáveis que pudessem sinalizar a realidade dessas quedas.

Constatamos que em todos os estados da federação os índices, por vezes oscilantes, mas predominantemente em queda, confirmaram a tendência nas quedas das matrículas nacionalmente. Desse ponto, partimos então para os dados qualitativos.

As horas de trabalho em que avançávamos os cálculos, tabelas e gráficos deu-nos a dimensão e as escalas que apontassem para o momento de alcançar uma determinante que respondesse ao problema dessa pesquisa. As entrevistas realizadas no processo da busca dos dados qualitativos foram fundamentais para formulação e sustentação do problema central da pesquisa.

Nesse caminho, os registros concentraram-se em dois aspectos: o rigor necessário aos procedimentos de investigação científica e da ética na pesquisa que envolve seres humanos. 
Aceitar as explicações oficiais sobre a redução das matrículas iniciais nesses cursos tão singulares entendia, naquele momento, assumir a responsabilidade integral por toda a situação declinante nos cursos de Jovens e Adultos trabalhadores.

Os problemas apresentados na EJA, como em toda à Educação, não foram poucos. No processo de delimitação do problema de pesquisa, encontramos dificuldades no recorte. Eram tantos problemas percebidos que sistematizamos um critério para o recorte. Partimos para a questão que julgávamos, naquele momento, a mais "enigmática" e acentuava-se entre os questionamentos nas unidades escolares selecionadas, ante a possibilidade de extinção aos cursos destinados ao Aluno Jovem Adulto e Trabalhador: a busca pela explicação real, ou próxima o mais possível da realidade, sobre o esvaziamento das salas de aula naquela localidade.

Esse trabalho tentou contribuir na desocultação às causas reais sobre o esvaziamento nas salas da EJA no período 2000 a 2012, contextualizado no seu tempo e espaço, observada a sua construção histórica.

Desse movimento, apropriamo-nos como norteadores do debate os conceitos de Trabalho e Educação e suas intrínsecas relações com as contradições no capitalismo. Esses conceitos norteadores emergiram de nosso trabalho em campo. No uso das metodologias quantitativas e qualitativas essenciais para esclarecer o objetivo central desta pesquisa.

Das quantitativas recorremos às bases de dados de instituições oficiais e organizações da sociedade civil que nos trouxeram em números as nossas primeiras investidas em busca por uma determinante que explicasse as quedas das matrículas na EJA.

Das qualitativas recorremos ao uso de questionários aplicados aos alunos nas três unidades selecionadas. 
As entrevistas informais com os professores contribuíram para o avanço do processo qualitativo da pesquisa. Importantes anotações foram registradas desse processo, como a descrição e queixas dos professores nas três escolas selecionadas, quando o assunto era a Reorganização da EJA no ano de 2008, promovida pela Secretaria Municipal de Educação: "foi uma confusão"; "foi um desgaste"; "ninguém entedia nada, não sabiam explicar como deveriam funcionar algumas coisas", entre outros relatos.

A entrevista com o professor R. contribuiu na questão central das quedas nos índices de matrículas. O trabalho de campo apontou as evidências no caminho da descoberta das questões que desejávamos compreender.

Desse entendimento, observamos que o tempo da vida individual (e privada) no capital é rareza, portanto, no capital é agregado o valor em dimensões fetichizantes: "o tempo é dinheiro". Desse discurso liberal o que se oculta é a ideologia. O tempo é dinheiro para o capital, para o trabalhador não é mais do que meio de circulação (MARX, 2010), que se objetiva-se somente para sua subsistência. O dinheiro real não é extraído do trabalho assalariado.

O professor e o aluno, principais sujeitos no processo educativo, não têm condições de pensar e (re) pensar em sua própria situação, isoladamente, sozinhos. Não é questão de conivência ou conveniência com o estado das coisas. O que emerge desse estado é o da alienação das coisas.

Algumas constatações emergiram no desenvolvimento deste trabalho. Outras ficaram pendentes e poderão alavancar futuros debates e pesquisas.

Do mundo do trabalho percebemos que suas bases e estruturas continuam inalteradas, destas, a mais-valia como fonte de manutenção, 
sustentação e perpetuação ao modo de produção e reprodução social no capitalismo. Os avanços alcançados nas técnicas não atingiram a maioria e a melhoria das condições do trabalho. Foram avanços das forças produtivas, apenas.

A promessa de que o "avanço tecnológico" contribuiria com a qualidade de vida do ser humano ainda não se cumpriu. Perversamente, o tempo "ganho" com o avanço tecnológico deixou o trabalho para poucos e o desemprego para grande parte da humanidade. A atual globalização trouxe desconforto para o mundo do trabalho em escala planetária. Hoje há consenso sobre o avanço na precarização do trabalho (BAUMAN, 1998; CHOSSUDOVSKY, 1999; SANTOS, M., 2001).

Da Educação, sob o capital, apreendemos atuar como equalizadora das necessidades do mercado de trabalho. As preocupações de governos têm sido em suprir mão-de-obra para o mercado. "Qualificar para o trabalho" é o que pronunciam em seus discursos.

O sentido dessa proposta de educação a reduz a simples treinamento. Em alguns momentos a Educação fetichizada, alavancando a esperança por uma vida melhor, um futuro melhor. Este futuro para muitos alunos dos atuais cursos da EJA tardará mais um pouco de tempo ou, talvez, não chegará se considerados os atuais termos em que neles se depositam algumas ações e politicas públicas educacionais.

Em outros momentos, como o da "melhoria" na oferta de trabalho, nos cíclicos momentos de "crescimento econômico" do capitalismo, a Educação de Jovens e Adultos é colocada à margem, tornando mais difíceis as possibilidades de real Educação à base da classe trabalhadora.

Os alunos da EJA nas escolas selecionadas deixaram os cursos ou interromperam a continuidade dos seus estudos para assumir postos de trabalho formais e informais, considerada a formação desse aluno e das relações entre os níveis de exigência de mercado para os postos de 
trabalho melhor estruturados, em condições gerais, muitos assumiram postos de trabalhos terceirizados, precarizados. Sazonais, entre as necessidades do trabalho no comércio e na construção civil.

No início da pesquisa usávamos um termo sobre a EJA, pensávamos que a EJA fosse uma modalidade de ensino secundarizada ante as outras modalidades do ensino, ou seja, em muitos momentos ficasse no segundo plano das coisas. Percebemos nesse momento que não é verdadeiro esse pensamento, consideradas as reflexões desta dissertação. Em certos e específicos aspectos não somente a EJA, mas a Educação de maneira geral oferecida ao trabalhador é secundarizada pela primazia ao trabalho, dessa colocação, entendemos duplo movimento.

Primeiro, pelo capital quando necessita da mão de obra específica e "treina" o trabalhador para atuar em determinados trabalhos necessários ao mercado. A seguir, pelo aluno na sua necessidade por sobrevivência e necessidades por aquisição dos produtos de consumo, dos quais, formam circularidade nessas relações sociais de dependências.

Partimos dessa noção e das considerações anteriores, das reflexões de Haddad (2007) e Pochmann (2007), que reforçam nossa ideia de que a EJA não é uma modalidade de ensino fadada à extinção, considerada a lógica da precariedade institucionalizada, desde a baixa qualidade do ensino aos baixos níveis de qualidade da população brasileira.

Nesse sentido, a EJA torna-se importante modalidade de ensino como formação continuada aos adultos da classe trabalhadora, contraponto nos processos de aligeiramento, historicamente, perpetuados nos processos de educação sob o capital.

Lembremos, ainda, que tanto o Trabalho quanto a Educação no contexto do capital são mercadorias. O que as diferencia é o ato do consumo, são as formas em que a cada uma delas alguns sujeitos se apropriam. 
Da contradição, enquanto categoria, vimos como se revela enquanto mecanismo de manutenção e perpetuação do capital. A manifestação da contradição emerge dos interesses antagônicos do homem e na sociedade de maneira geral. Cada qual toma suas ações segundo sua concepção de mundo na trajetória de suas existências. Nesse sentido, entendemos que as contradições constituem a componente limitadora para o avanço dos debates e reflexões no atual quadro da redução nas matrículas alavancadas pelo aumento da oferta dos empregos. Muitos debates ainda serão necessários para o melhor entendimento do problema.

Há de se colocar em pauta a discussão sobre a importância e a necessidade dos cursos de EJA para a sociedade brasileira. Ampliar os debates, repensar os aspectos que moldam os cursos de Educação dos Jovens e Adultos, criar espaços possíveis para o seu desenvolvimento e continuidade efetiva, com garantias de formação emancipadora.

Da Reorganização da EJA no ano de 2008 na cidade de São Paulo, ainda sequelas aparecem em muitos momentos. Destas, registramos em entrevistas com dirigentes na Capela do Socorro, bem como de outras partes da cidade, a tentativa da Secretaria Municipal de Educação paulistana tentar criar "Polos de atendimento" aos cursos de EJA.

O projeto central desses polos objetivava oferecer os cursos de EJA para toda a parcela de uma população local, num único equipamento escolar. As três escolas que selecionamos na pesquisa foram sondadas durante os últimos três anos para serem um desses polos. Na prática, os alunos iriam ser deslocados compulsoriamente para onde a administração regional local determinasse como polo. Esse aspecto contribuiu e muito para o acirramento da concorrência por alunos nas EM. " $A$ ", "B" e " $C$ ".

O projeto era tão contraditório que, em muitos aspectos, esbarravam na legalidade das portarias que a própria Secretaria Municipal de Educação havia editado e sustentado nos últimos anos. Não tratamos de dissertar sobre essa questão porque o projeto "morreu no ensaio", 
muitos professores se movimentaram contra, a direção das três escolas que selecionamos na pesquisa passavam certo relatório para os professores à quantas andavam a negociação desses polos e diante disso muitos movimentos contrários aconteceram para evitar o fechamento das salas de EJA nessas escolas. Com o final da gestão Kassab o projeto foi arquivado. Faltavam dados para que pudéssemos analisar devidamente 0 projeto, uma vez que não encontramos documentos oficiais.

Outra tentativa de modificação da EJA na Capela do Socorro nestes últimos anos foi criar a EJA modular. Escolas com sistema de aulas por módulos de disciplinas. A situação esbarrava novamente em aspectos de organização da própria Secretaria. Não se oficializou enquanto projeto, também ficou no ensaio. Sobre tal projeto, colhemos algumas informações em entrevista com o Prof. R.

Percebemos que as tentativas em organizar os cursos de EJA carecem de certa reflexão e estudos mais sérios para efetivação de suas possibilidades. Envolver de fato os professores nessas transformações e ouvir os alunos seria um começo razoável para essas mudanças.

Como tentativa de mudanças na criação, extensão, manutenção e continuidade desses cursos singulares, intentando proporcionar melhoria real no oferecimento desses cursos para os Jovens Adultos Trabalhadores, sentimos a necessidade de partir do conhecimento do funcionamento das "coisas" para pensar e repensar na melhor forma de sua apropriação.

Aos alunos adultos, que necessitem da EJA, que tenham a oportunidade por uma "aprendizagem e educação de adultos além da alfabetização básica e habilidade de vida", conforme Declaração de Evidência da VI CONFINTEA.

Torna-se importante que o debate realizado nesta pesquisa de pósgraduação chegue às instituições e órgãos que pensam, regularizam, normatizam e estabelecem o cotidiano escolar, sobretudo, que se proponham a um debate pela sua totalidade, isto é, que envolvam e que 
ouçam os argumentos dos principais sujeitos desta modalidade de ensino: o aluno e o professor.

Dessa reflexão, devolver aos seus protagonistas os resultados do que foi pensado neste trabalho, e assim, talvez contribuir para que se efetivem ações possíveis para a EJA, consideradas a realidade das escolas brasileiras em suas especificidades e localidades e do oferecimento aos cursos nessa modalidade do ensino.

Entendemos que tais ações atualmente têm sido analisadas e propostas a partir da periferia do problema, o que serve para mascarar ainda mais todo o complexo aparato dominante.

Como proposição e tentativa, entender a dinâmica nas relações do capital, das ações que possibilitem por tais mudanças, ou não. O importante é não aceitar passivamente, como fatalidade o atual estado das coisas.

Finalmente, o que falta investigar, nesta pesquisa, para além do esvaziamento das salas da EJA refere-se ao entendimento da evasão, o que merece mais estudos. Esta pesquisa contribui apenas para o estudo das quedas nas matrículas iniciais sob o aumento da oferta de trabalho.

Outra questão a investigar, a evidente denúncia à falta de relevância social dos nossos currículos para a EJA. Subjugados ao capital, os currículos tornam-se vulneráveis aos ventos que sopram em direção ao capital, conforme suas cíclicas crises e suas necessidades. Muitas vezes esquecendo-se ou afastando-se das necessidades humanas as que, verdadeiramente, deveriam ser priorizadas.

$\mathrm{Na}$ atualidade, mesmo em momento de oferta de trabalho no Brasil, alguns postos de trabalhos não estão sendo preenchidos por falta de mãode-obra qualificada. O debate precisa ser mais aprofundado, seriamente discutido. Segundo o Relatório Anexo da CONFINTEA VI, estamos diante de mudanças estruturais nos mercados da produção e de trabalho, dessa 
situação, de crescente inseguranças e ansiedades que se espalham em escala planetária, ameaçando a estabilidade da própria vida cotidiana, ante às dificuldades de compreensão mútua. Diante desse cenário, se avizinha profunda crise econômica e mundial.

No item 15 do mesmo Anexo encontramos interessante perspectiva sobre os cursos de EJA no mundo, que tem apresentado como foco uma educação de adultos enquanto capacitação profissional e vocacional, mas o documento aponta que faltam abordagens "mais integradas à aprendizagem e educação de adultos para tratar do desenvolvimento em todos os seus aspectos (econômico, sustentável, comunitário e pessoal)". O item 6 do relatório dá a medida que pode satisfazer aqueles que precisam de números rentáveis para o investimento em Educação de Adultos, "para cada ano que a média de educação da população adulta aumenta, há um acréscimo correspondente de 3,7\% no crescimento de longo prazo da economia e um acréscimo de $6 \%$ na renda per capita". (UNESCO, 2010)

Freire (2001) refletiu como reinventar a escola e a educação. Assim como reinventar também a vida social. Educação é uma invenção humana. Sendo assim podemos repensá-la/reinventá-la. Afinal, "o mundo não é. O mundo está sendo" (FREIRE, 2002, p. 85).

Parte da questão sobre as quedas nas matrículas iniciais foi elucidada. Também, em parte, entendemos para que, para quem e como se estrutura, não somente a Educação para Jovens e Adultos, mas a Educação em geral sob o capital. 


\section{REFERÊNCIAS}

AÇÃO EDUCATIVA. A educação de jovens e adultos no estado de São Paulo continua em queda. In: Viver, aprender. São Paulo, 2012. (Coleção didática criada para educação de jovens e adultos ) Disponível em: http:// www.viveraprender.org.br/2012/05/a-educacao-de-jovens-eadultos-no-estado-de-sao-paulo-continua-em-queda/, em 11/09/2012.

BARDIN, L. Análise de Conteúdo. Tradução de Pinheiro, A. e RETO, L.A. Lisboa: Persona, 1977. (Coleção Edições 70)

BAUMAN, Z. Globalização: as consequencias humanas. Tradução de PENCHEL, M., Rio de Janeiro: Jorge Zahar, 1999.

BRANDÃO, C.R. O que é educação. 3a ed. São Paulo: Brasiliense, 1981. (Coleção Primeiros Passos, 20)

CHOSSUDOVSKY, M. A globalização da pobreza: Impactos das reformas do FMI e do Banco Mundial. $1^{\text {aEd. }} 2^{\text {a }}$ Reimpr. Tradução de MICHAEL, M. P., São Paulo: Moderna, 1999.

CORSETTI, B. Análise documental no contexto da metodologia qualitativa. In: Universidade do Vale do Rio dos Sinos. São Leopoldo, RS: UNIrevista - vol 1, no 1:32-46 (janeiro 2006).

DAMIANI, A. L. A geografia e a construção da cidadania. In: CARLOS, A. F.A. (Org.) A geografia na sala de aula. São Paulo: Contexto, 1999a. (Coleção Repensando o Ensino)

DAMIANI, A. L. O lugar e a produção do cotidiano. In: CARLOS, A. F. A. (Org.) Novos caminhos da geografia. São Paulo: Contexto, 1999b. (Coleção Caminhos da Geografia)

DIEESE. O jovem comerciário: trabalho e estudo. Boletim Trabalho no Comércio, São Paulo, N.3, Ano 1, Maio de 2009. Disponível em: http://www.dieese.org.br/esp/boletimTrabalhoComercio3.pdf, em 05/01/2013, 16 h00min. 
DI PIERRO, M. C. e VIEIRA, R. Diagnóstico da EJA no Estado de São Paulo. In: Fórum Estadual de Educação de Jovens e Adultos - SP. São Paulo, 2008. Disponível em: http://forumeja.org.br/sp/?q=node8 em $30 / 01 / 2012$.

ENGels, F. A Origem da Família, da Propriedade Privada e do Estado. 3a Ed. 2006 - 4a Reimpressão. Tradução de Klaus, R.M., São Paulo: Centauro, 2009.

FÁVERO, O. Políticas públicas de educação de jovens e adultos no Brasil. In: Educação de jovens e adultos: políticas e práticas educativas. LOPES, A.C. [et.al.]; SOUZA, J.S. e SALES, S.R. (Orgs.), Rio de Janeiro: Naru, EDUR, 2010.

FRAZÃO, M. J. P. Cartas ao professor da roça: artigos relativos à instrução pública da Côrte, publicados no Constitucional de março a Abril de 1863. Rio de Janeiro: Typografia Paulo Brito, 1864. Disponível em www.brasiliana.usp.br/bbd/handle/1918/00725800\#page/1/mode/1up, em 20/10/2012.

FREIRE, P. Educação: o sonho possível. 8a Ed. BRANDÃO, C.R. (Org.) In: O educador: vida e morte. Rio de Janeiro: Graal, 1988.

. Educação como prática de liberdade. 19a Ed. Rio de Janeiro: Paz e Terra, 1989.

. Política e educação: ensaios. 6a Ed. São Paulo: Cortez, 2001. (Coleção Questões da Nossa Época; v.23)

- Pedagogia da autonomia: saberes necessários à prática educativa. 23aEd. São Paulo: Paz e Terra, 2002. (Coleção Leitura)

GUTBERLET, J. Análise de dados qualitativos, análise textual e semiótica. In: Metodologias Qualitativas, EDM 5111, São Paulo: F.E./USP, 2010. (Aula 11) 
HADDAD, S. Educação e Exclusão. In: Crescimento econômico e distribuição de Renda - prioridades para ação. MARCOVITCH, J. (Org.). São Paulo: EDUSP/Senac, 2007.

IBGE/PNAD. Aspectos complementares da educação de jovens e adultos e educação profissional: 2007. Rio de Janeiro: RJ, 2009, p. 35. (CD-ROM)

JACOBI, P. R. Ampliação da cidadania e participação: desafios na democratização da relação público-sociedade civil no Brasil. São Paulo: 1996. 278f. Livre Docência em Educação - Universidade de São Paulo, 1996.

KAUTSKY, K. As três fontes do marxismo. Tradução de LOURENÇO, C. R., 5a ed. São Paulo: Centauro, 2002.

KONDER, L. $O$ que é dialética? 28 ${ }^{\mathrm{a}}$ Ed. $8^{\mathrm{a}}$ Reimpr. São Paulo: Brasiliense, 2006. (Coleção primeiros passos)

LEFEBVRE, H. A vida quotidiana no mundo no mundo moderno. Lisboa: Ulisseia, 1969 [1968]. (cap. I, itens 2 a 7 e cap. II, itens 1 a 4 p. 23-84 e $97-152$ )

. De lo rural a lo urbano. Barcelona: Península, 1971. (p. 151-172, 195-203)

. La production de L'espace. Paris: Anthropos, 2000 [1974], 4.a edição. (cap. II - p. 83-172)

A produção do espaço. Tradução do Grupo "As (im) possibilidades do urbano na metrópole contemporânea", do núcleo de Geografia Urbana da UFMG, (do original: La production de L'espace. 4 éd. Paris: Éditions Anthropos, 2000) Primeira versão: início - fev. 2006.

. Marxismo. Tradução de LAGOS, W., Porto Alegre:

L\&PM, 2010. 
MADUREIRA, A. F. do A. Metodologia Qualitativa. Brasília: Instituto de Educação Superior, 2000. In: Metodologias Qualitativas - EDM 5111, São Paulo: FEUSP, 2010. (Texto organizado com fins didáticos)

MARX, K. A origem do capital: a acumulação primitiva. Tradução PUCHEN, K. V., 2 ed., 1 Reimpressão. São Paulo: Centauro, 2009.

Capítulo VI inédito de 0 Capital, resultados do processo de produção imediata. Tradução PUCHEN, K.V., São Paulo: Centauro, 2010.

MÉSZÁROS, I. A educação para além do capital. Tradução de TAVARES, I, 2a Ed. Ampliada. São Paulo: Boitempo, 2008. (Coleção Mundo do Trabalho)

MOREIRA, E. de A. Políticas públicas para a educação de jovens e adultos na região metropolitana de São Paulo - RMSP: o caso do ProJovem (2005-2007). São Paulo: 2008. 150f. Dissertação (Mestrado em Geografia Humana) - Universidade de São Paulo, 2009.

NEUMANN, I.B. Discourse analysis. Tradução de OVCHINNIKOV, A.; SOUZA, M.R., In: Klotz, A. \& Prakash, D. (Orgs.) Qualitative research in international relation, Palgrave Macmillan, 2008, Cap. 5, p. 61-77.

OLIVEIRA, J.F. Educação Escolar e Currículo: Por que as reformas curriculares têm fracassado no Brasil? In: DOURADO, L.F. (Org.) Políticas e gestão da educação no Brasil: novos marcos regulatórios. OLIVEIRA, D.A. [et. al.]. São Paulo: Xamã, 2009.

PATO, M.H.S. A produção do fracasso escolar: histórias de submissão e rebeldia. São Paulo: T.A. Queiroz, 1990. (Biblioteca de Psicologia e psicanálise; v. 6)

PLEINES, J. E. Friedrich Hegel. Tradução, Organização: FILHO, S. R. Recife: Fundação Joaquim Nabuco; Massangana, 2010, 132 p. il. (Coleção Educadores) 
POCHMANN, M. Sentidos do trabalho no Brasil: Hora de intervir. In: Crescimento econômico e distribuição de Renda - prioridades para ação. MARCOVITCH, J. (Org.). São Paulo: EDUSP/SENAC, 2007.

PONTUSCHKA, N. N. Fundamentos para um projeto interdisciplinar: supletivo profissionalizante. PONTUSCHKA e OLIVEIRA (Orgs.), Geografia em perspectiva. $2^{a}$ ed. São Paulo: Contexto, 2004, 187-194p.

RUMMERT, J.V.S. Considerações político-pedagógicas sobre as especificidades da educação de jovens e adultos trabalhadores. In: Educação de jovens e adultos: políticas e práticas educativas. LOPES, A.C. [et.al.]; SOUZA, J.S. e SALES, S.R. (Orgs.). Rio de Janeiro: Naru, EDUR, 2010.

SANTOS, M. Por uma outra globalização: do pensamento único à consciência universal. 8ª Ed., Rio de Janeiro: Record, 2001.

SÃO PAULO (SP). Secretaria Municipal de Educação. Diretoria de Orientação Técnica. In: Reorganização da EJA Educação de jovens e adultos da rede municipal de ensino de São Paulo. São Paulo: SME / DOT, 2008, 56 p.

SÃO PAULO (SP). Coletânea de textos legais. RME (Org.), São Paulo: S.M.E., 2008. (p. 144-149)

SÃO PAULO (SP). Projeto Pedagógico da EM Marina Melander Coutinho. São Paulo: D.R.E-C.S/S.M.E., 2011.

SILVA, R. N. Educação de jovens e adultos na rede municipal de São Paulo: Diálogos entre as políticas públicas e as práticas docentes e seus significados. São Paulo: 2013. 145f. Dissertação (Mestrado em Geografia Humana) - Universidade de São Paulo, 2013.

TELLES, V.S. e CABANES, R. (org.) Nas tramas da cidade. São Paulo: Humanitas, 2006. (p. 35-116, 327-341) 
TROTSKY, L. A revolução traída. Tradução de FERNANDES, J. e CARVALHO, M., São Paulo: Centauro, 2008

UNESCO. Relatório Global Sobre Aprendizagem e Educação de Adultos. Brasília: UNESCO, 2010, 156p. Disponível em: http://unesdoc.unesco.org/images/0018/001886/188644por.pdf.em30/01 /2012.

UNESCO. Sexta Conferência Internacional de Educação de Adultos - CONFINTEA VI: Marco de Ação de Belém. Brasília: UNESCO, 2010a, $23 p$.

http://forumeja.org.br/sites/forumeja.org.br/files/miolo_Marco em $30 / 01 / 2012$.

WACQUANT, L. As prisões da miséria. Tradução de TELLES, A., $1^{a}$ ed., Rio de Janeiro: Zahar, 2001. 


\section{APÊNDICES}

APÊNDICE A - Quadro dos índices das Evoluções nas Matrículas de EJA, por estados.

\begin{tabular}{|c|c|c|c|c|c|}
\hline Quadro 0 & $\begin{array}{l}3 \text { - Cálculo } \\
\text { Período - }\end{array}$ & $\begin{array}{l}\text { das Evoluções na } \\
2000 \text { a } 2012\end{array}$ & $\begin{array}{l}5 \text { Matrí } \\
\text { BASE }\end{array}$ & $\begin{array}{l}\text { las de EJ } \\
\text { abela OC }\end{array}$ & $\begin{array}{l}\text { A ANO / ANO } \\
\text { D3 }\end{array}$ \\
\hline ACRE & & & AMAZO & & \\
\hline Ano & Matric. & \% Evol. Ano/Ano & & Matric. & $\%$ Evol. Ano/Ano \\
\hline 2000 & 19.964 & & 2000 & 53.705 & \\
\hline 2001 & 41.851 & 109,63 & 2001 & 59.417 & 10,64 \\
\hline 2002 & 37.426 & $-10,57$ & 2002 & 74.926 & 26,10 \\
\hline 2003 & 38.029 & 1,61 & 2003 & 75.827 & 1,20 \\
\hline 2004 & 35.961 & $-5,44$ & 2004 & 80.053 & 5,57 \\
\hline 2005 & 31.436 & $-12,58$ & 2005 & 88.380 & 10,40 \\
\hline 2006 & 27.971 & $-11,02$ & 2006 & 94.684 & 7,13 \\
\hline 2007 & 21.180 & $-24,28$ & 2007 & 82.269 & $-13,11$ \\
\hline 2008 & 19.184 & $-9,42$ & 2008 & 70.030 & $-14,88$ \\
\hline 2009 & 17.092 & $-10,90$ & 2009 & 67.691 & $-3,34$ \\
\hline 2010 & 16.190 & $-5,28$ & 2010 & 63.108 & $-6,77$ \\
\hline 2011 & 16.619 & 2,65 & 2011 & 63.832 & 1,15 \\
\hline 2012 & 19.859 & 19,50 & 2012 & 62.385 & $-2,27$ \\
\hline ALAGOAS & & & AMA & & \\
\hline & Matric. & \% Evol. Ano/Ano & & Matric. & $\%$ Evol. Ano/Ano \\
\hline 2000 & 36.255 & & 2000 & 26.527 & \\
\hline 2001 & 77.762 & 114,49 & 2001 & 24.787 & $-6,56$ \\
\hline 2002 & 91.191 & 17,27 & 2002 & 23.249 & $-6,20$ \\
\hline 2003 & 95.828 & 5,08 & 2003 & 22.312 & $-4,03$ \\
\hline 2004 & 99.501 & 3,83 & 2004 & 23.799 & 6,66 \\
\hline 2005 & 101.386 & 1,89 & 2005 & 22.386 & $-5,94$ \\
\hline 2006 & 105.283 & 3,84 & 2006 & 21.539 & $-3,78$ \\
\hline 2007 & 92.133 & $-12,49$ & 2007 & 17.868 & $-17,04$ \\
\hline 2008 & 91.066 & $-1,16$ & 2008 & 17.386 & $-2,70$ \\
\hline 2009 & 99.302 & 9,04 & 2009 & 16.731 & $-3,77$ \\
\hline 2010 & 85.411 & $-13,99$ & 2010 & 16.851 & 0,72 \\
\hline 2011 & 97.327 & 13,95 & 2011 & 17.360 & 3,02 \\
\hline 2012 & 88.672 & $-8,89$ & 2012 & 16.619 & $-4,27$ \\
\hline BAHIA & & & CEAKK & & \\
\hline & Matric. & \% Evol. Ano/Ano & & Matric. & $\%$ Evol. Ano/Ano \\
\hline 2000 & 8.841 & & 2000 & 124.233 & \\
\hline 2001 & 43.776 & 395,15 & 2001 & 184.910 & 48,84 \\
\hline 2002 & 84.397 & 92,79 & 2002 & 189.910 & 2,70 \\
\hline 2003 & 105.020 & 24,44 & 2003 & 207.586 & 9,31 \\
\hline 2004 & 373.362 & 255,52 & 2004 & 229106 & 10,37 \\
\hline 2005 & 387.828 & 3,87 & 2005 & 228.666 & $-0,19$ \\
\hline 2006 & 391.306 & 0,90 & 2006 & 234.881 & 2,72 \\
\hline 2007 & 370.007 & $-5,44$ & 2007 & 175.297 & $-25,37$ \\
\hline 2008 & 377.339 & 1,98 & 2008 & 156.524 & $-10,71$ \\
\hline 2009 & 364.619 & $-3,37$ & 2009 & 141.988 & $-9,29$ \\
\hline 2010 & 327.836 & $-10,09$ & 2010 & 123.197 & $-13,23$ \\
\hline 2011 & 317.973 & $-3,01$ & 2011 & 117.725 & $-4,44$ \\
\hline 2012 & 300.084 & $-5,63$ & 2012 & 115.724 & $-1,70$ \\
\hline
\end{tabular}




\begin{tabular}{|c|c|c|c|c|c|}
\hline \multicolumn{6}{|c|}{ Continua Quadro 013} \\
\hline \multicolumn{3}{|c|}{ Distrito Federal } & \multicolumn{3}{|c|}{ Espírito Santo } \\
\hline & Matric. & \% Evol. Ano/Ano & & Matric. & $\%$ Evol. Ano/Anc \\
\hline 2000 & 68.868 & & 2000 & 50.712 & \\
\hline 2001 & 66.369 & $-3,63$ & 2001 & 54.619 & 7,70 \\
\hline 2002 & 19.009 & $-71,36$ & 2002 & 50.446 & $-7,64$ \\
\hline 2003 & 16.282 & $-14,35$ & 2003 & 52.448 & 3,97 \\
\hline 2004 & 14.268 & $-12,37$ & 2004 & 48.229 & $-8,04$ \\
\hline 2005 & 12.074 & $-15,38$ & 2005 & 37.730 & $-21,77$ \\
\hline 2006 & 40.074 & 231,90 & 2006 & 34.029 & $-9,81$ \\
\hline 2007 & 33.075 & $-17,47$ & 2007 & 28.735 & $-15,56$ \\
\hline 2008 & 33.574 & 1,51 & 2008 & 31.602 & 9,98 \\
\hline 2009 & 27.946 & $-16,76$ & 2009 & 35.737 & 13,08 \\
\hline 2010 & 26.800 & $-4,10$ & 2010 & 37.654 & 5,36 \\
\hline 2011 & 28.249 & 5,41 & 2011 & 37.362 & $-0,7 \varepsilon$ \\
\hline 2012 & 26.959 & $-4,57$ & 2012 & 37.971 & 1,63 \\
\hline \multicolumn{2}{|l|}{ Goiás } & \multicolumn{4}{|c|}{ Maranhão } \\
\hline & Matric. & $\%$ Evol. Ano/Ano & & Matric. & $\%$ Evol. Ano/Ano \\
\hline 2000 & 42.535 & & 2000 & 75.672 & \\
\hline 2001 & 58.053 & 36,48 & 2001 & 120.258 & 58,92 \\
\hline 2002 & 82.210 & 41,61 & 2002 & 168.621 & 40,22 \\
\hline 2003 & 89.503 & 8,87 & 2003 & 274.631 & 62,87 \\
\hline 2004 & 86.289 & $-3,59$ & 2004 & 225.038 & $-18,06$ \\
\hline 2005 & 76.076 & $-11,84$ & 2005 & 221.776 & $-1,45$ \\
\hline 2006 & 67.029 & $-11,89$ & 2006 & 225.883 & 1,85 \\
\hline 2007 & 50.072 & $-25,30$ & 2007 & 184.384 & $-18,37$ \\
\hline 2008 & 46.696 & $-6,74$ & 2008 & 172.968 & $-6,19$ \\
\hline 2009 & 41.349 & $-11,45$ & 2009 & 171.758 & $-0,70$ \\
\hline 2010 & 44.726 & 8,17 & 2010 & 162.783 & $-5,23$ \\
\hline 2011 & 37.592 & $-15,95$ & 2011 & 155.954 & $-4,20$ \\
\hline 2012 & 34.105 & $-9,28$ & 2012 & 142.526 & $-8,61$ \\
\hline \multicolumn{3}{|c|}{ Mato Grosso Sul } & \multicolumn{3}{|c|}{ Mato Grosso } \\
\hline & Matric. & \% Evol. Ano/Ano & & Matric. & $\%$ Evol. Ano/Anc \\
\hline 2000 & 34.410 & & 2000 & 18.943 & \\
\hline 2001 & 3.335 & $-90,31$ & 2001 & 23.307 & 23,04 \\
\hline 2002 & 9.488 & 184,50 & 2002 & 27.366 & 17,42 \\
\hline 2003 & 46.435 & 389,41 & 2003 & 20.999 & $-23,27$ \\
\hline 2004 & 42.620 & $-8,22$ & 2004 & 18.121 & $-13,71$ \\
\hline 2005 & 44.267 & 3,86 & 2005 & 32.540 & 79,57 \\
\hline 2006 & 45.950 & 3,80 & 2006 & 55.642 & 71,00 \\
\hline 2007 & 44.448 & $-3,27$ & 2007 & 55.111 & $-0,95$ \\
\hline 2008 & 47.710 & 7,34 & 2008 & 54.345 & $-1,39$ \\
\hline 2009 & 46.588 & $-2,35$ & 2009 & 57.303 & 5,44 \\
\hline 2010 & 27.802 & $-40,32$ & 2010 & 62.182 & 8,51 \\
\hline 2011 & 26.474 & $-4,78$ & 2011 & 62.466 & 0,46 \\
\hline 2012 & 22.170 & $-16,26$ & 2012 & 55.376 & $-11,35$ \\
\hline
\end{tabular}




\begin{tabular}{|c|c|c|c|c|c|}
\hline \multicolumn{6}{|c|}{\begin{tabular}{|l} 
Continua Quadro 013 \\
\end{tabular}} \\
\hline \multicolumn{3}{|c|}{ Minas Gerais } & \multicolumn{3}{|l|}{ Pará } \\
\hline & Matric. & $\%$ Evol. Ano/Ano & & Matric. & $\%$ Evol. Ano/Anc \\
\hline 2000 & 23.460 & & 2000 & 188.035 & \\
\hline 2001 & 43.884 & 87,06 & 2001 & 231.770 & 23,26 \\
\hline 2002 & 45.971 & 4,76 & 2002 & 253.951 & 9,57 \\
\hline 2003 & 52.127 & 13,39 & 2003 & 265.865 & 4,69 \\
\hline 2004 & 64.018 & 22,81 & 2004 & 275.515 & 3,63 \\
\hline 2005 & 90.437 & 41,27 & 2005 & 283.007 & 2,72 \\
\hline 2006 & 132.018 & 45,98 & 2006 & 272.812 & $-3,60$ \\
\hline 2007 & 166.981 & 26,48 & 2007 & 231.270 & $-15,23$ \\
\hline 2008 & 178.674 & 7,00 & 2008 & 217.641 & $-5,89$ \\
\hline 2009 & 162.701 & $-8,94$ & 2009 & 221.660 & 1,85 \\
\hline 2010 & 156.618 & $-3,74$ & 2010 & 211.910 & $-4,40$ \\
\hline 2011 & 144.014 & $-8,05$ & 2011 & 198.523 & $-6,32$ \\
\hline 2012 & 137.635 & $-4,43$ & 2012 & 193.944 & $-2,31$ \\
\hline \multicolumn{3}{|c|}{ Paraíba } & \multicolumn{3}{|c|}{ Paraná } \\
\hline & Matric. & \% Evol. Ano/Ano & & Matric. & $\%$ Evol. Ano/Anc \\
\hline 2000 & 44.055 & & 2000 & 167.449 & \\
\hline 2001 & 62.925 & 42,83 & 2001 & 146.991 & $-12,22$ \\
\hline 2002 & 93.677 & 48,87 & 2002 & 106.041 & $-27,86$ \\
\hline 2003 & 118.847 & 26,87 & 2003 & 104.413 & $-1,54$ \\
\hline 2004 & 132.410 & 11,41 & 2004 & 70.239 & $-32,73$ \\
\hline 2005 & 142.591 & 7,69 & 2005 & 60.033 & $-14,53$ \\
\hline 2006 & 150.812 & 5,77 & 2006 & 98.519 & 64,11 \\
\hline 2007 & 112.704 & $-25,27$ & 2007 & 111.174 & 12,85 \\
\hline 2008 & 110.181 & $-2,24$ & 2008 & 106.681 & $-4,04$ \\
\hline 2009 & 104.023 & $-5,59$ & 2009 & 90.932 & $-14,76$ \\
\hline 2010 & 99.608 & $-4,24$ & 2010 & 91.401 & 0,52 \\
\hline 2011 & 101.931 & 2,33 & 2011 & 80.498 & $-11,93$ \\
\hline 2012 & 103.615 & 1,65 & 2012 & 82.878 & 2,96 \\
\hline \multicolumn{3}{|c|}{ Pernambuco } & \multicolumn{3}{|l|}{ Piauí } \\
\hline & Matric. & \% Evol. Ano/Ano & & Matric. & $\%$ Evol. Ano/Anc \\
\hline 2000 & 134.078 & & 2000 & 28.490 & \\
\hline 2001 & 173.129 & 29,13 & 2001 & 80.507 & $182,5 \varepsilon$ \\
\hline 2002 & 213.232 & 23,16 & 2002 & 113.655 & 41,17 \\
\hline 2003 & 239.832 & 12,47 & 2003 & 150.492 & 32,41 \\
\hline 2004 & 262.879 & 9,61 & 2004 & 136.264 & $-9,45$ \\
\hline 2005 & 262.023 & $-0,33$ & 2005 & 125.188 & $-8,13$ \\
\hline 2006 & 273.102 & 4,23 & 2006 & 133.218 & 6,41 \\
\hline 2007 & 236.286 & $-13,48$ & 2007 & 91.624 & $-31,22$ \\
\hline 2008 & 235.759 & $-0,22$ & 2008 & 90.122 & $-1,64$ \\
\hline 2009 & 223.117 & $-5,36$ & 2009 & 88.396 & $-1,92$ \\
\hline 2010 & 215.919 & $-3,23$ & 2010 & 77.733 & $-12,06$ \\
\hline 2011 & 192.815 & $-10,70$ & 2011 & 69.493 & $-10,60$ \\
\hline 2012 & 180.450 & $-6,41$ & 2012 & 64.417 & $-7,30$ \\
\hline
\end{tabular}




\begin{tabular}{|c|c|c|c|c|c|}
\hline \multicolumn{6}{|c|}{ Continua Quadro 013} \\
\hline \multicolumn{3}{|c|}{ Rio de Janeiro } & \multicolumn{3}{|c|}{ Rio Grande do Norte } \\
\hline & Matric. & \% Evol. Ano/Ano & & Matric. & $\%$ Evol. Ano/Ano \\
\hline 2000 & 217.921 & & 2000 & 75.681 & \\
\hline 2001 & 184.179 & $-15,48$ & 2001 & 103.904 & 37,29 \\
\hline 2002 & 216.200 & 17,39 & 2002 & 116.697 & 12,31 \\
\hline 2003 & 228.064 & 5,49 & 2003 & 126.729 & 8,60 \\
\hline 2004 & 247.707 & 8,61 & 2004 & 130.381 & 2,88 \\
\hline 2005 & 239.948 & $-3,13$ & 2005 & 128.029 & $-1,80$ \\
\hline 2006 & 237.338 & $-1,09$ & 2006 & 117.815 & $-7,98$ \\
\hline 2007 & 217.740 & $-8,26$ & 2007 & 94.414 & $-19,86$ \\
\hline 2008 & 221.927 & 1,92 & 2008 & 82.249 & $-12,88$ \\
\hline 2009 & 207.620 & $-6,45$ & 2009 & 74.508 & $-9,41$ \\
\hline 2010 & 209.134 & 0,73 & 2010 & 74.988 & 0,64 \\
\hline 2011 & 173.091 & $-17,23$ & 2011 & 73.838 & $-1,53$ \\
\hline 2012 & 147.278 & $-14,91$ & 2012 & 67.485 & $-8,60$ \\
\hline \multicolumn{3}{|c|}{ Rio Grande do Sul } & \multicolumn{3}{|c|}{ Rondônia } \\
\hline & Matric. & $\%$ Evol. Ano/Ano & & Matric. & $\%$ Evol. Ano/Ano \\
\hline 2000 & 97.239 & & 2000 & 36.010 & \\
\hline 2001 & 93.785 & $-3,55$ & 2001 & 33.330 & $-7,44$ \\
\hline 2002 & 100.574 & 7,24 & 2002 & 47.063 & 41,20 \\
\hline 2003 & 104.681 & 4,08 & 2003 & 49.258 & 4,66 \\
\hline 2004 & 114.373 & 9,26 & 2004 & 45.222 & $-8,19$ \\
\hline 2005 & 115.712 & 1,17 & 2005 & 39.714 & $-12,18$ \\
\hline 2006 & 114.354 & $-1,17$ & 2006 & 38.133 & $-3,98$ \\
\hline 2007 & 104.076 & $-8,99$ & 2007 & 34.118 & $-10,53$ \\
\hline 2008 & 96.085 & $-7,68$ & 2008 & 33.344 & $-2,27$ \\
\hline 2009 & 89.474 & $-6,88$ & 2009 & 36.031 & 8,06 \\
\hline 2010 & 85.933 & $-3,96$ & 2010 & 34.086 & $-5,40$ \\
\hline 2011 & 83.586 & $-2,73$ & 2011 & 30.398 & $-10,82$ \\
\hline 2012 & 82.863 & $-0,86$ & 2012 & 28.631 & $-5,81$ \\
\hline \multicolumn{3}{|l|}{ Roraima } & \multicolumn{3}{|c|}{ Santa Catarina } \\
\hline & Matric. & $\%$ Evol. Ano/Ano & & Matric. & $\%$ Evol. Ano/Ano \\
\hline 2000 & 6.715 & & 2000 & 89.946 & \\
\hline 2001 & 16.307 & 142,84 & 2001 & 97.175 & 8,04 \\
\hline 2002 & 13.642 & $-16,34$ & 2002 & 69.847 & $-28,12$ \\
\hline 2003 & 20.734 & 51,99 & 2003 & 64.577 & $-7,55$ \\
\hline 2004 & 17.397 & $-16,09$ & 2004 & 58.087 & $-10,05$ \\
\hline 2005 & 15.068 & $-13,39$ & 2005 & 33.918 & $-41,61$ \\
\hline 2006 & 11.345 & $-24,71$ & 2006 & 64.293 & 89,55 \\
\hline 2007 & 8.073 & $-28,84$ & 2007 & 49.739 & $-22,64$ \\
\hline 2008 & 7.167 & $-11,22$ & 2008 & 39.370 & $-20,85$ \\
\hline 2009 & 5.018 & $-29,98$ & 2009 & 44.123 & 12,07 \\
\hline 2010 & 6.336 & 26,27 & 2010 & 37.904 & $-14,09$ \\
\hline 2011 & 4.921 & $-22,33$ & 2011 & 35.826 & $-5,48$ \\
\hline 2012 & 5.081 & 3,25 & 2012 & 30.026 & $-16,19$ \\
\hline
\end{tabular}




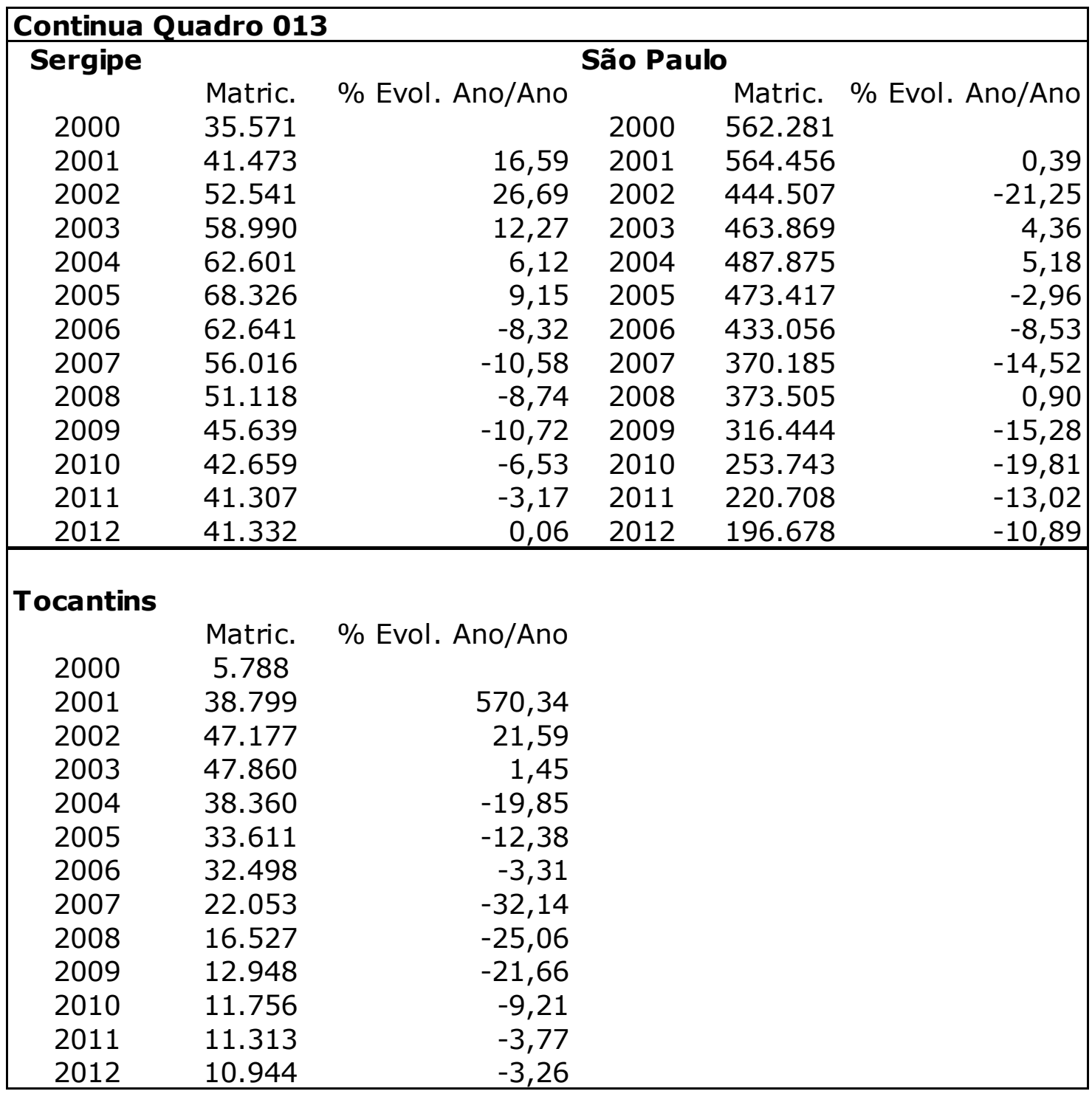

Fonte: INEP - Instituo Nacional de Estudos e Pesquisas Educacionais Anísio Teixeira Disponível em: http://portal.inep.gov.br/web/guest/basica-censo-escolar-matricula Organizado por Márcio Rocha de Souza, 2012.

$\begin{array}{ll}\text { Obs.: Dos Dados: } & 2000 \text { a } 2011 \text { - Resultados Finais do Censo Escolar } \\ \text { (BASE: TABELA 03) } & 2012 \text { - Resultados Preliminares do Censo Escolar }\end{array}$

APÊNDICE B - Comparativo Relacional entre Estados/Gestões

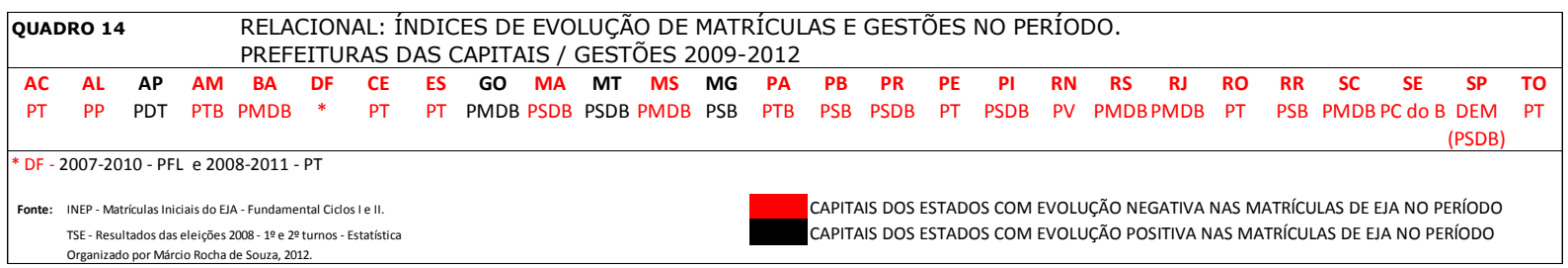


APÊNDICE C - Evolução no uso da Análise de Conteúdo em estudos

\begin{tabular}{|c|c|c|c|c|}
\hline \begin{tabular}{|l|} 
Quadro 15 \\
Evolução da \\
Período: 190
\end{tabular} & $\begin{array}{l}\text { Análise de C } \\
-1960\end{array}$ & Zonteúdo em & studos, em & nédia anual. \\
\hline $1900-1920$ & $1920-1930$ & $1930-1940$ & $1940-1950$ & $1950-1960$ \\
\hline 2,5 & 13,3 & 22,8 & 43,3 & mais de 100 \\
\hline
\end{tabular}

APÊNDICE D - Tabela que evidencia o ano de 2007 como marco nos índices de quedas nas matrículas dos cursos de EJA pelo Brasil.

TABELA 3 B

MATRÍCULAS INICIAIS - EJA - FUNDAMENTAL I e II - POR ESTADOS

BASE DOS DADOS: TOTAIS ( FEDERAIS, ESTADUAIS, MUNICIPAIS E PRIVADAS)

PERÍODO: 2000 A 2012. Por índices de quedas e aumentos.

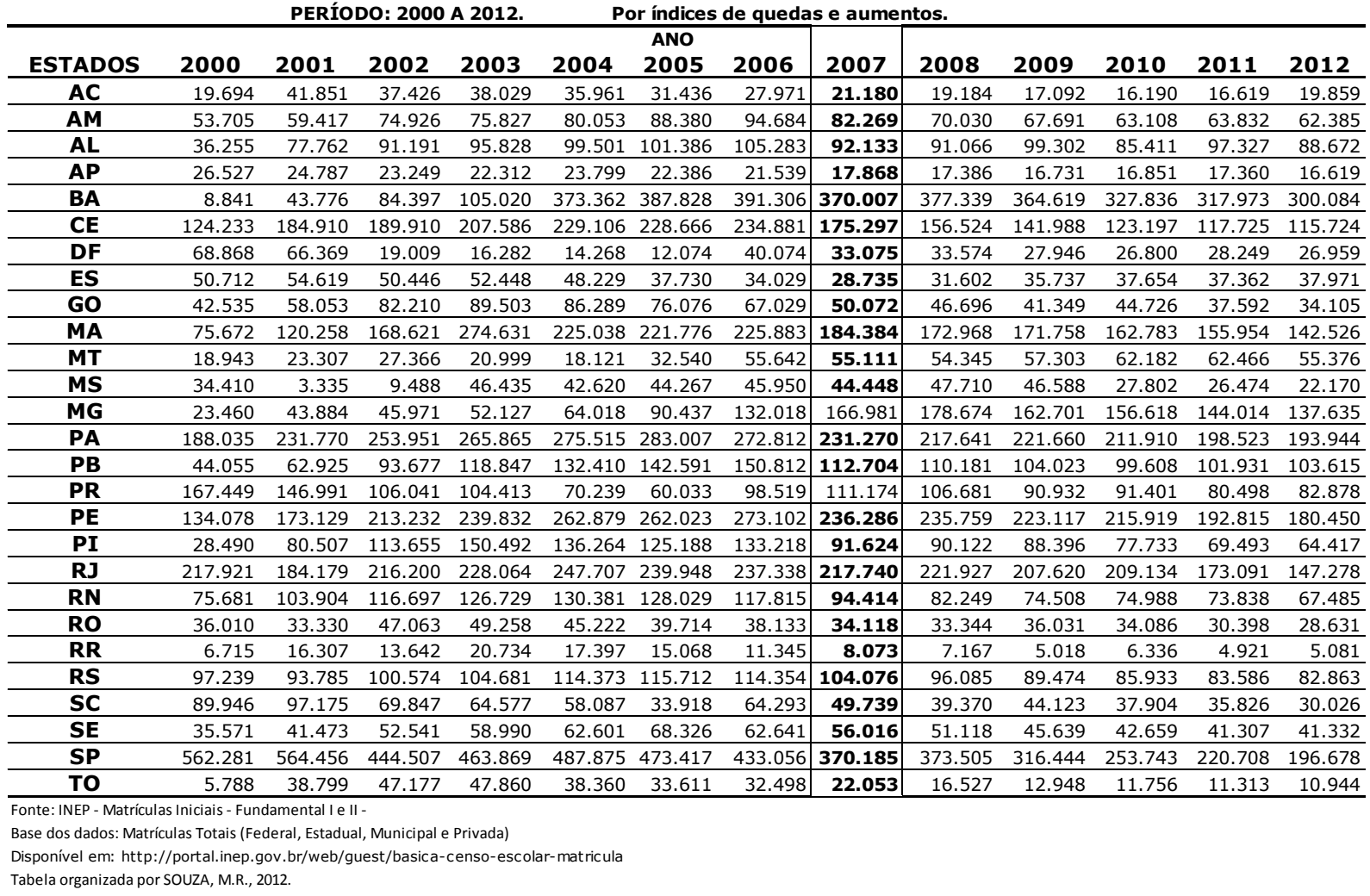


APÊNDICE E - Tabela de todos os estados brasileiros, que demonstram índices de crescimento das carteiras de trabalho assinadas.

Tabela 9

EVOLUÇÃO DAS CARTEIRAS DE TRABALHO ASSINADAS - Empregados

PERIODICIDADE: ANUAL

\begin{tabular}{|c|c|c|c|c|c|c|c|c|c|}
\hline \multirow[b]{2}{*}{ UF } & \multicolumn{9}{|c|}{ ANO } \\
\hline & 2001 & 2002 & 2003 & 2004 & 2005 & 2006 & 2007 & 2008 & 2009 \\
\hline Acre & 38,79 & 32,61 & 36,59 & 37,76 & 37,74 & 38,85 & 42,76 & 51,48 & 45,07 \\
\hline Alagoas & 39,93 & 43,17 & 43,08 & 39,86 & 40,6 & 41,2 & 46,65 & 45,58 & 45,64 \\
\hline Amapá & 43,8 & 42,17 & 29,59 & 31,57 & 34,5 & 37,59 & 38,99 & 40,67 & 37,15 \\
\hline Amazonas & 48,85 & 48,44 & 49,94 & 48,68 & 44,82 & 51,5 & 48,79 & 51,08 & 50,02 \\
\hline Bahia & 38,68 & 37,58 & 39,73 & 39,26 & 39,98 & 41,08 & 42,4 & 43,56 & 43,99 \\
\hline Ceará & 38,9 & 40,73 & 41,32 & 40,96 & 41,65 & 41,43 & 44,6 & 44,75 & 44,2 \\
\hline Distrito Federal & 51,31 & 52,6 & 54,37 & 54,28 & 53,04 & 54,04 & 54,98 & 54,89 & 57,66 \\
\hline Espírito Santo & 50,93 & 50,81 & 50,86 & 51,12 & 53,86 & 57,48 & 57,6 & 56,99 & 59,97 \\
\hline Goiás & 43,95 & 45,29 & 45,87 & 47,67 & 49,78 & 52,07 & 53,18 & 54,53 & 54,39 \\
\hline Maranhão & 30,3 & 25,09 & 29,56 & 30,98 & 31,36 & 30,73 & 35,17 & 38,7 & 39,13 \\
\hline Mato Grosso & 41,12 & 44,65 & 43,64 & 44,86 & 48,32 & 49,04 & 51,21 & 52,52 & 54,97 \\
\hline Mato G. do Sul & 51,22 & 51,42 & 52,82 & 51,18 & 57,31 & 57,05 & 56,8 & 57,09 & 59,57 \\
\hline $\begin{array}{l}\text { Minas Gerais } \\
\text { Pará }\end{array}$ & $\begin{array}{l}53,13 \\
37,17\end{array}$ & $\begin{array}{l}53,83 \\
34,39\end{array}$ & $\begin{array}{l}54,75 \\
38,64\end{array}$ & $\begin{array}{l}54,86 \\
36,33\end{array}$ & $\begin{array}{l}56,86 \\
40,95\end{array}$ & $\begin{array}{l}57,16 \\
38,02\end{array}$ & $\begin{array}{l}58,9 \\
38,08\end{array}$ & $\begin{array}{l}59,86 \\
40,03\end{array}$ & $\begin{array}{l}59,46 \\
40,03\end{array}$ \\
\hline Paraíba & 37,51 & 33,9 & 35,36 & 32,91 & 35,43 & 34,59 & 36,31 & 37,04 & 37,48 \\
\hline Paraná & 60,25 & 61,99 & 62,63 & 61,59 & 63,41 & 64,1 & 63,7 & 65,04 & 65,67 \\
\hline Pernambuco & 40,29 & 42,3 & 44,12 & 43,07 & 44,92 & 45,36 & 48,5 & 46,87 & 50,56 \\
\hline Piauí & 28,74 & 27,84 & 31,96 & 32,15 & 31,69 & 31,33 & 33,13 & 34,07 & 33,22 \\
\hline Rio de Janeiro & 60,77 & 59,81 & 61,11 & 60,15 & 63,05 & 61,48 & 62,1 & 62,89 & 64,58 \\
\hline Rio G. do Norte & 38,01 & 35,29 & 42,89 & 38,44 & 40,12 & 44,45 & 43,95 & 45,74 & 48,09 \\
\hline Rio G. do Sul & 61,68 & 61,42 & 61,58 & 63,31 & 63,68 & 62,8 & 63,07 & 63,67 & 65,18 \\
\hline Rondônia & 45,7 & 47,87 & 44,22 & 45,82 & 47,37 & 42,22 & 45,54 & 49,49 & 49,8 \\
\hline Roraima & 25,77 & 19,31 & 18,38 & 26,94 & 23,05 & 25,88 & 29,66 & 31,34 & 32,41 \\
\hline Santa Catarina & 69,88 & 68,77 & 67,86 & 70,28 & 70,6 & 70,89 & 71,52 & 71,04 & 72,32 \\
\hline Sergipe & 44,81 & 44,05 & 41,4 & 42,24 & 44,36 & 41 & 42,15 & 48,83 & 44,75 \\
\hline São Paulo & 65,81 & 65,68 & 66,28 & 66,82 & 67,62 & 68,09 & 69,52 & 71,34 & 72,38 \\
\hline Tocantins & 24,1 & 24,65 & 23 & 26,7 & 29,49 & 30,42 & 33,03 & 33,84 & 32,15 \\
\hline
\end{tabular}

Fonte: IBGE -

Série Estatísticas e Históricas, Mercado e Força de Trabalho, Carteira de Trabalho Assinada - Empregados

Tipo de Dados: RELATIVOS

Opção: TOTAL (Homens e Mulheres)

Organizado por SOUZA, M.R., 2012. 
APÊNDICE F - Gráficos comparativos dos índices de quedas nas matrículas iniciais de EJA e dos índices de crescimentos da oferta de trabalho com carteiras assinadas, em todos os estados brasileiros.

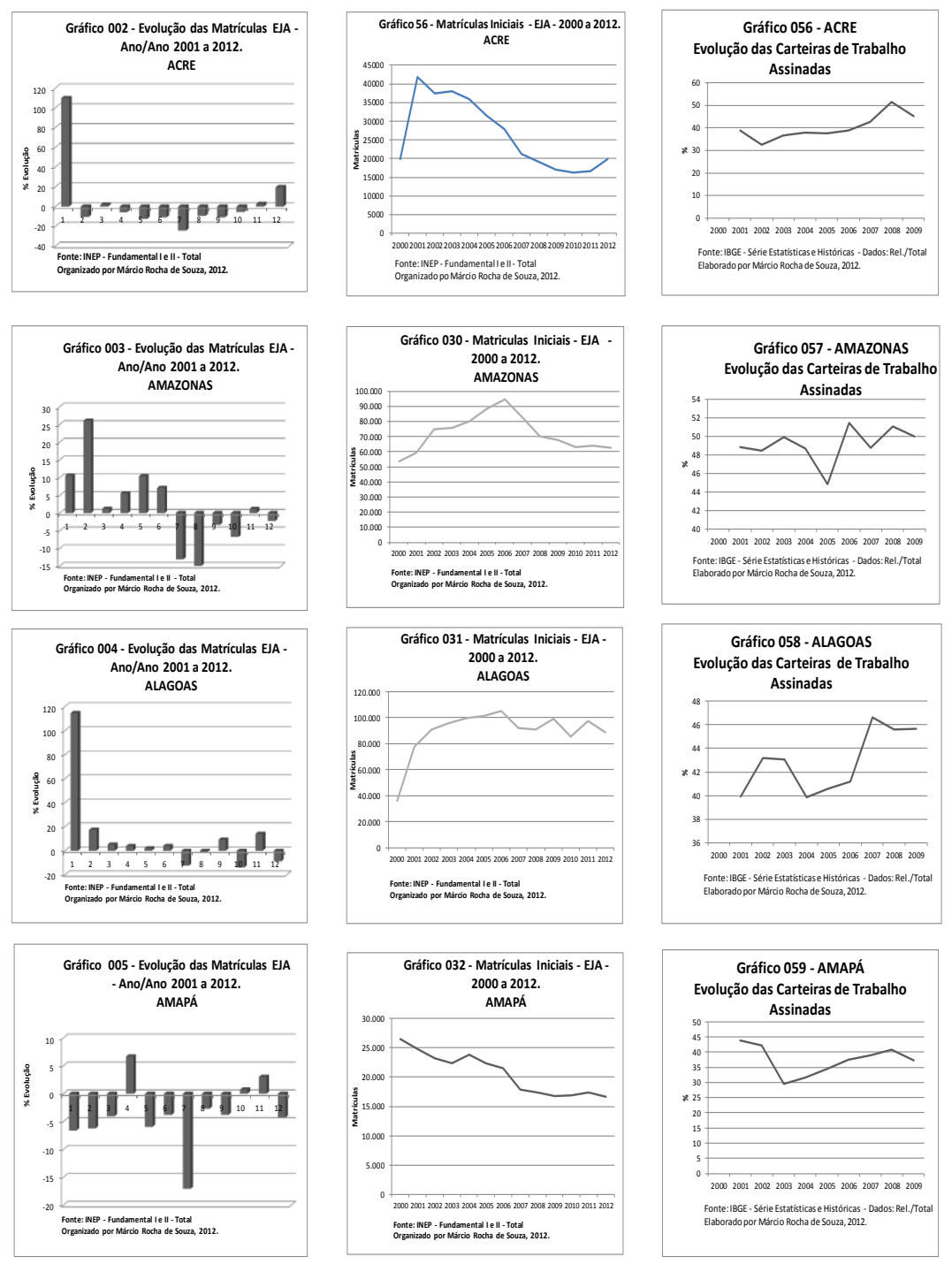



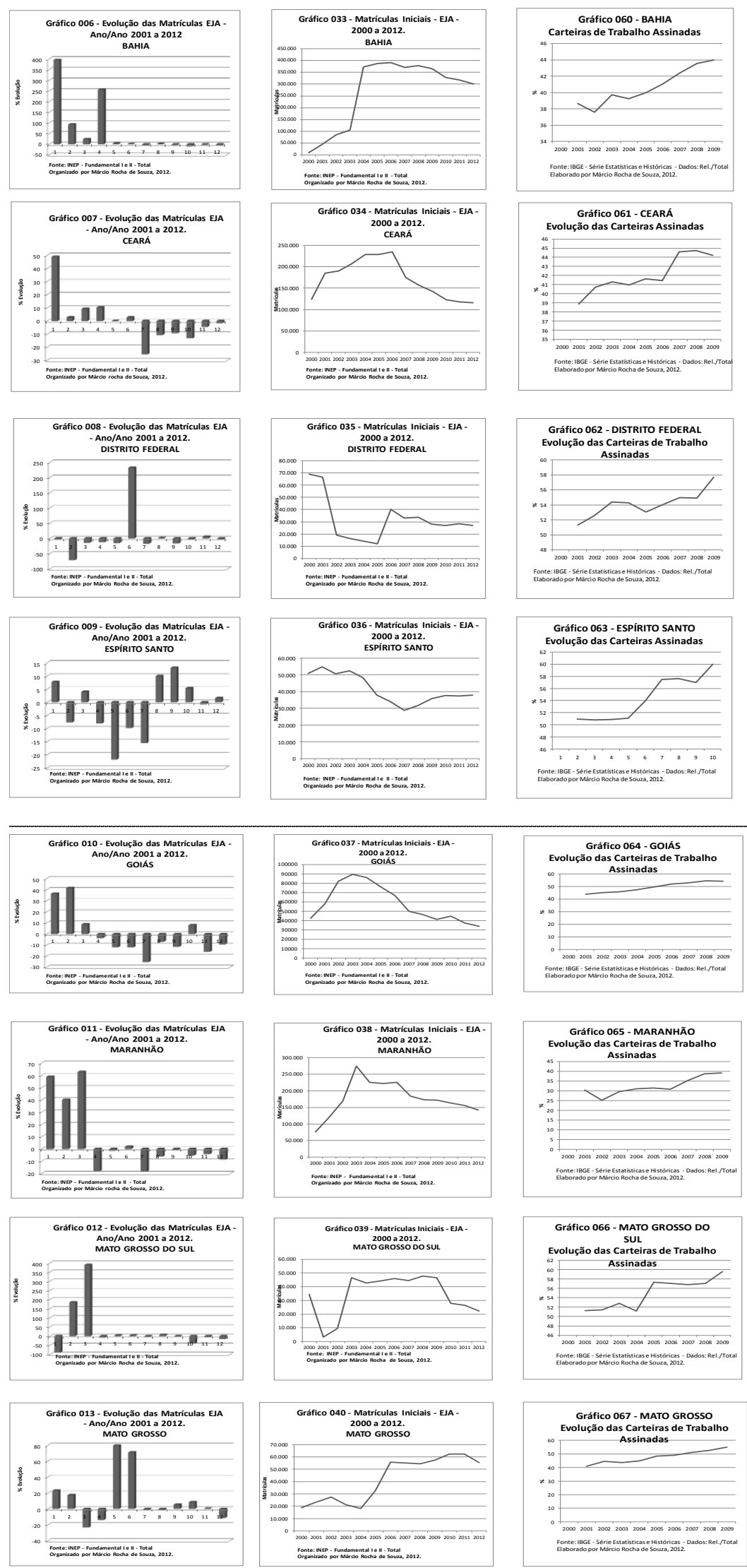

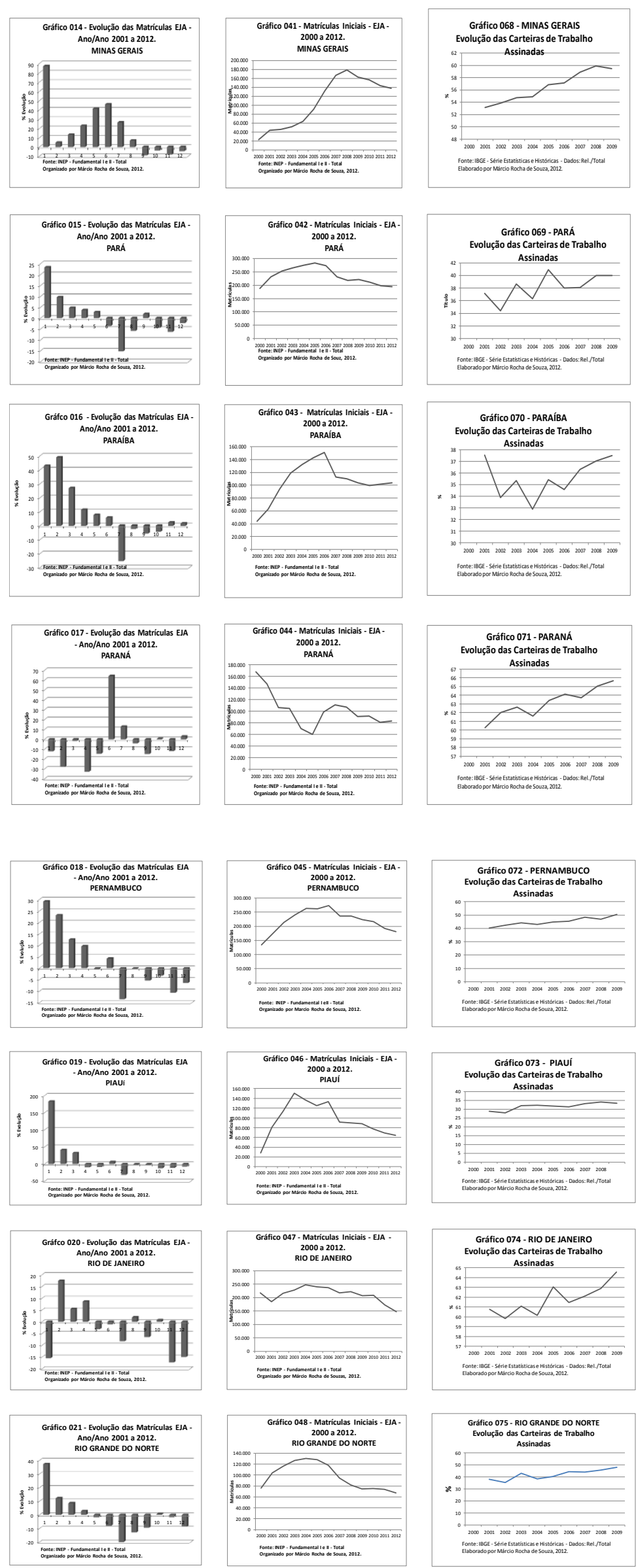

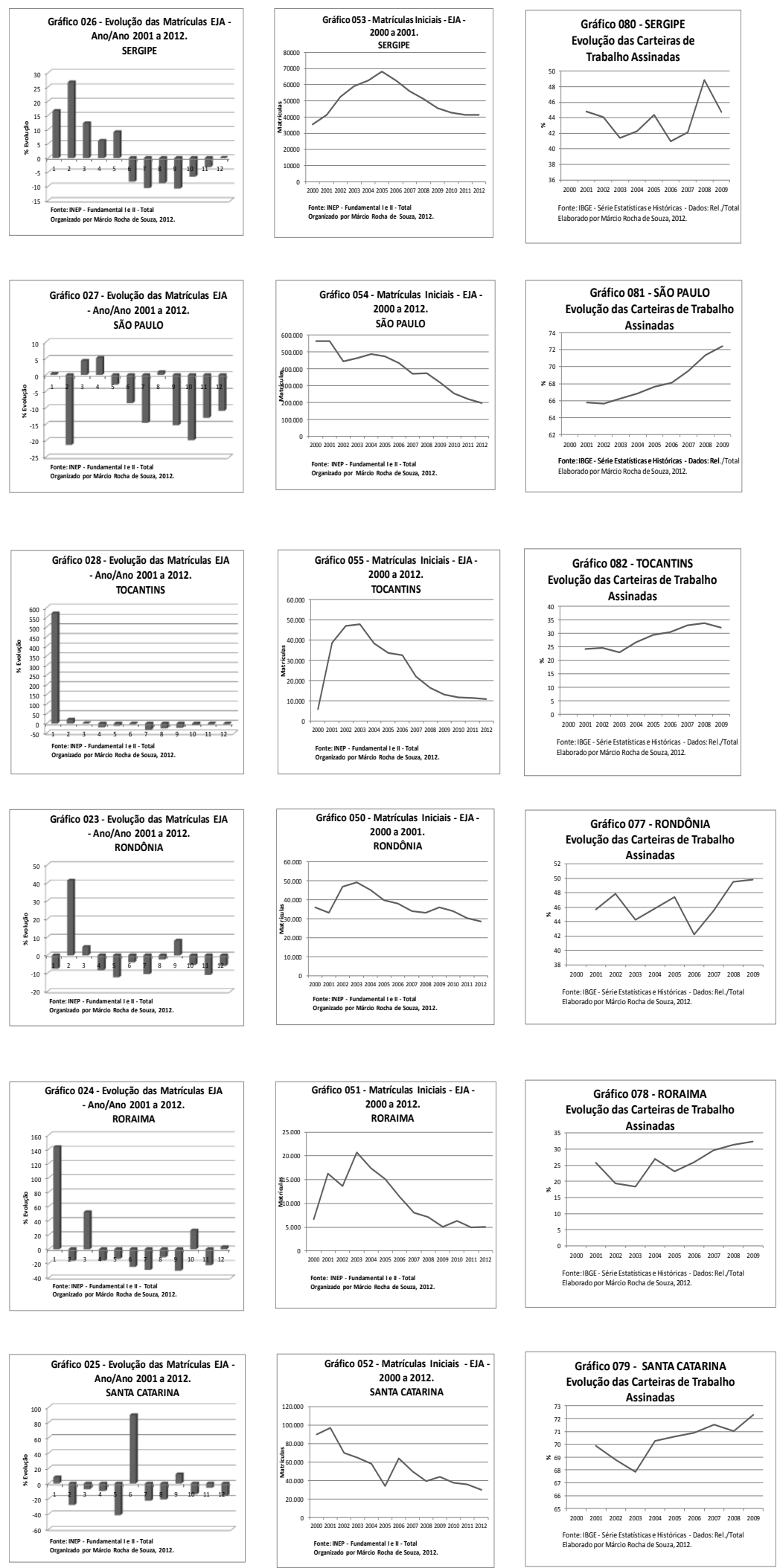
APÊNDICE G - Questionário aplicados aos professores nas EM.s "A", "B" e "C".

Questionário de Pesquisa - Professores

Educação para Jovens e Adultos

EMEF

Nome

Disciplina:

1 - Há quanto tempo você trabalha com o Ensino Fundamental e há quanto tempo você trabalha com a Educação para Jovens e Adultos?

$2-\mathrm{O}$ que mais o motiva a trabalhar com a EJA?

3 - Dos desafios dessa modalidade de ensino qual ou quais têm sido os temas dos debates entre seus colegas?

4 - Você participa ou já participou de algum projeto coletivo e interdisciplinar em EJA? Se afirmativo, como esse processo se deu?

5 - A que disciplina, ou a quais disciplinas, você se aproximaria numa proposta de trabalho coletivo interdisciplinar para EJA? Explique.

6 - Qual é a sua opinião sobre uma proposta de trabalho interdisciplinar para EJA, a ser realizado na escola em que você ministra aulas?

7 - Que caminhos você sugere para a melhoria do ensino para a Educação de Jovens e Adultos? 
APÊNDICE H - Questionário aplicado aos alunos nas EM.s "A", "B" e "C".

Questionário de Pesquisa - $\underline{\text { Alunos }}$

Educação para Jovens e Adultos

\section{EMEF}

Nome: Etapa

Idade: Sexo: ( ) M ( ) F

\section{A - Sobre você:}
A1 - Você trabalha?
( ) $\operatorname{sim}$
( ) não

A2 - Se trabalha está:

( ) registrado ( ) sem registro ( ) por conta própria ( ) Outros

Se outros, explique:

A3 - Vem para a escola:

( ) do trabalho ( ) de casa ( ) trabalho/casa/escola ( ) Outros

Se outros, explique:

A4 - Qual é a distância da sua casa ao seu trabalho?

( ) 0 a $2 \mathrm{~km}$ ( ) 2 a $4 \mathrm{~km}$ ( ) 4 a $6 \mathrm{~km}$ ( ) 6 a 10km ( ) mais de $10 \mathrm{~km}$

A5 - Qual é a distância entre sua casa e a escola?

( ) - de 500m ( ) $500 \mathrm{~m}$ ( ) $1 \mathrm{~km}$ ( ) $2 \mathrm{~km} \mathrm{(} \mathrm{)} 3 \mathrm{~km} \mathrm{(} \mathrm{)} 4 \mathrm{~km}($ ) + de $5 \mathrm{~km}$

A5 - Qual é o tempo de seu deslocamento até à escola?

( ) $10 \min ($ ) $20 \min ($ ) $30 \mathrm{~min}$ ( ) 40min ( ) $50 \mathrm{~min}($ ) + de $1 \mathrm{~h}$

A7 - Qual é o seu meio de locomoção até a escola:

( ) carro próprio ( ) transporte público ( ) a pé ( ) Outros

A8 - Você estuda nessa escola, por quê?

( ) gosta ( ) única com vaga ( ) acha boa ( ) é mais próxima ( ) Outros Se outros, explique: 


\section{B-Sobre o seu estudo:}

B1 - Antes de chegar nesta escola, onde você estudava?

B2 - Qual o motivo de sua vinda para a EJA nesta escola?

B3 - Há quanto tempo você não estudava? Por quê?

B4 - O que levou você a voltar a estudar em EJA, ou a continuar a estudar?

B5 - O que você espera da escola?

B6 - O que mais o motiva a continuidade dos estudos?

B7 - O que pode levar você a desistir dos estudos?

B8 - O que você sugere para a melhoria do seu curso em EJA?

B9 - Das disciplinas que você estuda qual, ou quais, você possui maior facilidade em estudar?

B10 - O que você acha da disciplina da Geografia? Explique.

B11 - No seu dia-a-dia, onde você pode usar o que você aprendeu em Geografia?

B12 - Neste ano, de tudo o que você aprendeu na escola, o que mais teve significado em sua vida? Explique. 
APÊNDICE I - Tabulação das respostas dos questionários aplicados aos

alunos nas EM. "A", "B" e "C".

Tabela 10 - Questionário geral aplicado aos alunos — Item A: "Sobre você"

EMEF-A: 68 EMEF-B: 72 e EMEF-C: 23 - NOV/DEZ 2011

\begin{tabular}{|c|c|c|c|c|}
\hline $\begin{array}{l}\text { Sexo: } \\
\text { Idades: }\end{array}$ & Masculino & 61 & Feminino & 102 \\
\hline Homens & & Mulheres & & \\
\hline $15-19$ & 17 & $15-19$ & 17 & \\
\hline $20-29$ & 16 & $20-29$ & 13 & \\
\hline $30-39$ & 14 & $30-39$ & 28 & \\
\hline $40-49$ & 6 & $40-49$ & 16 & \\
\hline $50-59$ & 3 & $50-59$ & 14 & \\
\hline Mais de 60 & 2 & Mais de 60 & 3 & \\
\hline Não declarou & 3 & Não declarou & 11 & \\
\hline
\end{tabular}

A1 - Você trabalha?

\begin{tabular}{ccc} 
Sim & Não & Não respondeu \\
\hline $\mathbf{1 1 5}$ & $\mathbf{4 6}$ & $\mathbf{2}$ \\
\hline
\end{tabular}

A2 - Se trabalha, está:

\begin{tabular}{ccccc} 
Registrado & Sem registro & Conta própria & Outros & Não respondeu \\
\hline $\mathbf{5 9}$ & $\mathbf{4 2}$ & $\mathbf{1 6}$ & $\mathbf{5}$ & $\mathbf{4 1}$ \\
\hline $\mathbf{A 3}$ - Vem para a escola: & & & \\
& & & Trabalho/Casa \\
Do trabalho & De casa & $\mathbf{3 6}$ & outros & $\begin{array}{l}\text { Não } \\
\text { respondeu }\end{array}$ \\
\hline $\mathbf{4 1}$ & $\mathbf{6 9}$ & $\mathbf{3 6}$ & $\mathbf{7 0}$ \\
\hline
\end{tabular}

A4 - Qual é a distância da sua casa ao seu trabalho?

\begin{tabular}{cccccc}
0 A $2 \mathrm{~km}$ & $2 \mathrm{~A} 4 \mathrm{~km}$ & 4 A $6 \mathrm{~km}$ & 6 A $10 \mathrm{~km}$ & $\begin{array}{l}\text { Mais de } \\
10 \mathrm{~km}\end{array}$ & $\begin{array}{l}\text { Não } \\
\text { respondeu }\end{array}$ \\
\hline $\mathbf{2 9}$ & $\mathbf{2 5}$ & $\mathbf{4}$ & $\mathbf{2 1}$ & $\mathbf{5 0}$ & $\mathbf{3 4}$
\end{tabular}

\begin{tabular}{cccccccc}
\hline \multicolumn{4}{l}{ A5 - Qual é a distância entre sua casa e a escola? } & & & \multicolumn{3}{c}{} \\
Menos de $500 \mathrm{~m}$ & $500 \mathrm{~m}$ & $1 \mathrm{~km}$ & $2 \mathrm{~km}$ & $3 \mathrm{~km}$ & $4 \mathrm{~km}$ & $\begin{array}{l}\text { Mais } \\
5 \mathrm{~km}\end{array}$ & $\begin{array}{c}\text { de Não } \\
\text { respondeu }\end{array}$ \\
\hline $\mathbf{8}$ & $\mathbf{1 6}$ & $\mathbf{2 4}$ & $\mathbf{2 7}$ & $\mathbf{2 2}$ & $\mathbf{1 8}$ & $\mathbf{3 2}$ & $\mathbf{1 6}$ \\
\hline
\end{tabular}

A6 - Qual é o tempo de seu deslocamento até à escola?

\begin{tabular}{ccccccc}
$10 \mathrm{~min}$ & $20 \mathrm{~min}$ & $30 \mathrm{mim}$ & $40 \mathrm{~min}$ & $50 \mathrm{~min}$ Mais de $1 \mathrm{~h}$ & $\begin{array}{l}\text { Não } \\
\text { respondeu }\end{array}$ \\
\hline $\mathbf{3 3}$ & $\mathbf{4 3}$ & $\mathbf{3 7}$ & $\mathbf{1 6}$ & $\mathbf{1 0}$ & $\mathbf{1 8}$ & $\mathbf{6}$
\end{tabular}

A7 - Qual é o seu meio de locomoção até à escola?

\begin{tabular}{|c|c|c|c|c|c|c|}
\hline carro próprio & transporte público & & a pé & outros & & não respondeu \\
\hline 10 & 67 & & 81 & 5 & & $\mathbf{0}$ \\
\hline \multicolumn{7}{|c|}{ A8 - Você estuda nessa escola, por quê? } \\
\hline gosta & a única com vaga & acha boa & é a mais & oróxima & outros & não respondeu \\
\hline 31 & 25 & 47 & & 56 & 2 & 3 \\
\hline
\end{tabular}

Tabela 10 - Elaborada por: SOUZA, M.R., 2011. 
Tabela 11 - Questionário geral aplicado aos alunos "Sobre o seu estudo"

Total de Alunos Pesquisados: 163

EMEFs: A, B e C - NOV/DEZ 2011

B 1 - Antes de chegar nesta escola onde você estudava?

Alunos

$\begin{array}{lc}\text { Não lembra } & 1 \\ \text { Na igreja } & 2 \\ \text { Em branco } & 4 \\ \text { Mova } & 3 \\ \text { Na mesma unidade escolar } & 5 \\ \text { Escolas Municipais próximas } & 19 \\ \text { Escolas Municipais outras } & 5 \\ \text { Escolas Estaduais próximas } & 14 \\ \text { Escolas Estaduais outras } & 13 \\ \text { Escolas particulares } & 1 \\ \text { Em casa } & 1 \\ \text { Outra cidade de São Paulo } & 3 \\ \text { Outro Estado } & 38 \\ \text { Não estudava } & 45 \\ \text { Não respondeu } & 6 \\ \text { Outros } & 3 \\ \text { TOTAL } & \mathbf{1 6 3}\end{array}$

B 2 - Qual o motivo de sua vinda para a EJA nesta Alunos escola?

Alfabetização

Conclusão $\quad 11$

Conhecimento 10

Continuidade 2

Em branco $\quad 4$

Formação $\quad 20$

Indicação $\quad 2$

Não respondeu $\quad 49$

Não tabulado 1

Necessidade $\quad 2$

Oportunidade $\quad 3$

Outros $\quad 4$

Perspectivas $\quad 12$

Preferência $\quad 5$

Proximidade 3

Qualidade $\quad 10$

Repetência $\quad 2$

Saúde 1

Trabalho 13

Transferência

$\begin{array}{ll}\text { TOTAL } & 163\end{array}$ 
Tabela 11 - Questionário geral aplicado aos alunos "Sobre o seu estudo"

Total de Alunos Pesquisados: 163

EMEFs: A, B e C - NOV/DEZ 2011

B 3 - Há quanto tempo você não estudava? Alunos Por quê?

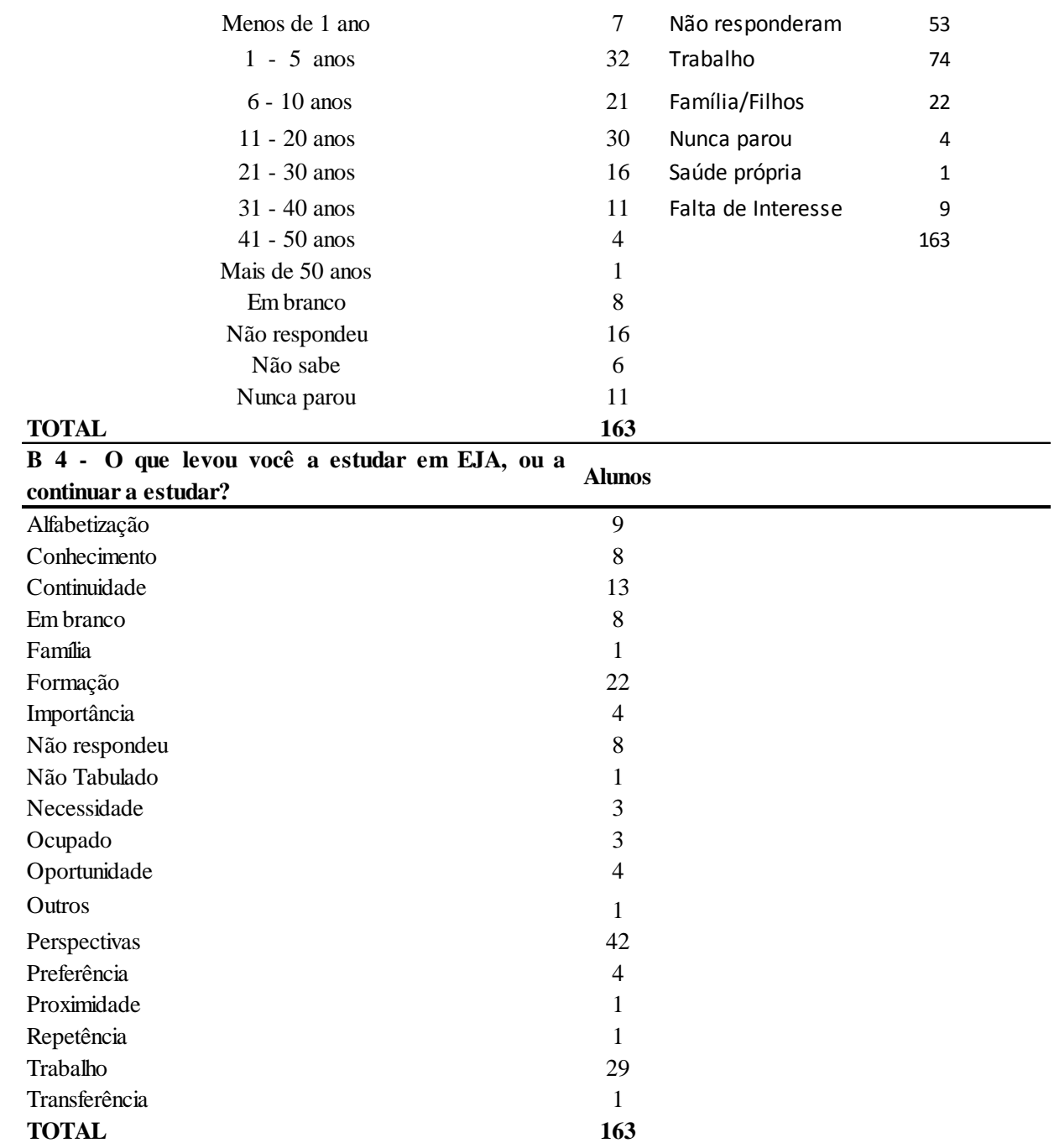

Tabela 11 - Questionário geral aplicado aos alunos "Sobre o seu estudo" Total de Alunos Pesquisados: 163

EMEFs: A, B e C - NOV/DEZ 2011

\begin{tabular}{lc}
\hline B 5 - O que você espera da escola? & Alunos \\
\hline Alfabetização & 3 \\
Conhecimento & 31 \\
Continuidade & 12 \\
Disciplina & 1 \\
Em branco & 9 \\
Formação & 16 \\
Importância & 1 \\
Não respondeu & 9 \\
Oportunidade & 10 \\
Outros & 1 \\
Perspectivas & 32 \\
Qualidade & 36 \\
Sem expectativas & 2 \\
TOTAL & $\mathbf{1 6 3}$ \\
\hline
\end{tabular}


B 6 - O que mais o motiva a continuiade dos estudos? Alunos

\begin{tabular}{lc}
\hline Alfabetização & 1 \\
Amigos & 6 \\
Autonomia & 1 \\
Conhecimento & 22 \\
Disciplina & 1 \\
Em branco & 9 \\
Familia & 6 \\
Formação & 33 \\
Não respondeu & 1 \\
Não sabe & 1 \\
Oportunidade & 3 \\
Os professores & 2 \\
Perspectivas & 39 \\
Proximidade & 1 \\
Qualidade & 4 \\
Trabalho & 33 \\
TOTAL & $\mathbf{1 6 3}$
\end{tabular}

Tabela 11 - Questionário geral aplicado aos alunos "Sobre o seu estudo"

Total de Alumos Pesquisados: 163

EMEFs: A, B e C - NOV/DEZ 2011

B 7 - O que pode levar você a desistir dos estudos? Alunos

Falta de vaga

Desempenho

Outros

Motivação

Indisciplina

Ausência

Aula vaga

Desemprego

Distância

Doença

Insatisfação

Nada

Não aprender

Não sabe

Familia

Imprevistos

Retenção

Trabalho

Não respondeu

Em branco

TOTAL

Continua

Tabela 11 - Questionário geral aplicado aos alunos "Sobre o seu estudo"

Total de Alunos Pesquisados: 163

EMEFs: A, B e C - NOV/DEZ 2011

B 8 - O que você sugere para a melhoria do seu curso Alunos em EJA?

Compreensão (pelos professores)

Compromisso (dos professores)

Continuidade

Dedicação (dos professores)

Didática

Diminuição de faltas (professores)

Diminuição das desistências

Diminuição de Alunos

Em branco

Flexibilização dos horários

Mais alunos na EJA

Mais conteúdo

Manter tudo como está

Mater a disciplina

Melhoria da qualidade

Motivação

Não respondeu

Não sabe

Não tabulado

Qualidade

Reestruturação da grade curricular

Reformas (prédio)

Segurança

Sem sugestão

Separação entre alfabetizados e não alfabetizados

Separação entre adultos e adolescentes

TOTAL 
Continua

Tabela 11 - Questionário geral aplicado aos alunos "Sobre o seu estudo"

Total de Alunos Pesquisados: 163

EMEFs: A, B e C - NOV/DEZ 2011

B 9 - Das disciplinas que você estuda qual, ou quais, você possui maior facilidade em estudar?

Alunos

Artes

17

Ciências

53

Espanhol

2

Geografia

40

História

63

Inglês

14

Língua Portuguesa $\quad 47$

Matemática $\quad 44$

Embranco $\quad 9$

Não respondeu $\quad 5$

Não tabulado 4

Obs.: Questão com múltiplas respostas, 163 participantes.

B 10 - O que você acha da disciplina de Geografia? Alunos

Aprende-se muito 1

Aprende-se pouco 5

Boa $\quad 72$

Complicada 2

Em branco 16

Excelente 2

Gosta 8

Importante $\quad 8$

Interessante $\quad 10$

Não Gosta 3

Não respondeu $\quad 13$

Não sabe 1

Ótima 16

Outro 1

Ruim 5

TOTAL 163

B 10 -Explique

INTERESSANTE: APRENDE-SE SOBRE PAÍSES;

RUIM: REPETITIVAS; PROF. CHATO; FALTA

DEDICAÇÃO; NÃO FALA DA MATÉRIA; NÃO FAZ LEITURAS

BOA: APRENDE-SE SOBRE O MUNDO;

CONHECIMENTOS; LOCALIZAÇÃO; É

NECESSÁRIA; PARA O DIA-A-DIA; APRENDE-SE

HISTÓRIA DO

IMPORTANTE: CONHECER LUGARES

ÓTIMA: BOA EXPLICAÇÃO; COISAS QUE EU

NÃO SABIA 
Tabela 10 - Questionário geral aplicado aos alunos "Sobre o seu estudo"

Total de Alunos Pesquisados: 163

EMEFs: A, B e C - NOV/DEZ 2011

B 11 - No seu dia-a-dia, onde você pode usar o que você aprendeu em Geografia?

\section{Alunos}

$\begin{array}{lc}\text { No meio ambiente } & 8 \\ \text { Atualidades } & 3 \\ \text { Em branco } & 14 \\ \text { Em tudo } & 6 \\ \text { Escola/Amigos/Família/Trabalho } & 39 \\ \text { Não aprendi } & 2 \\ \text { Não respondeu } & 34 \\ \text { Não sabe } & 10 \\ \text { Nenhum lugar } & 11 \\ \text { No dia-a-dia } & 4 \\ \text { Palestras } & 1 \\ \text { Para localização } & 15 \\ \text { Poucas coisas } & 5 \\ \text { Reconhecer lugares } & 10 \\ \text { Trabalho } & 1 \\ \text { TOTAL } & \mathbf{1 6 3}\end{array}$
B 12 - Neste ano, de tudo o que você aprendeu na
escola, oque mais teve significado em sua vida?

$\begin{array}{lc}\text { Alfabetização } & 2 \\ \text { Amizades } & 1 \\ \text { Aprender sobre a vida } & 4 \\ \text { Atualização } & 1 \\ \text { Compreensão ( por parte dos professores) } & 4 \\ \text { Compromisso (dos professores) } & 1 \\ \text { Conhecimento } & 53 \\ \text { Conquista (o diploma) } & 1 \\ \text { Convívio } & 11 \\ \text { Dedicação } & 1 \\ \text { Determinação } & 1 \\ \text { Em branco } & 28 \\ \text { Falar corretamente } & 1 \\ \text { Leitura } & 3 \\ \text { Não respondeu } & 24 \\ \text { Organização } & 1 \\ \text { Perseverança } & 3 \\ \text { Produtivo } & 1 \\ \text { Sonhar } & 1 \\ \text { Trabalhos em Equipe } & 1 \\ \text { Tudo } & 163 \\ \text { Voltar à escola } & 1 \\ \text { TOTAL } & 9\end{array}$

Tabela 11 - Elaborada por: SOUZA, M.R., 2011. 
APÊNDICE J - Questões para entrevista em DRE.

PESQUISADOR: MÁRCIO ROCHA DE SOUZA

Entrevista agendada para 19/12/2012, às $14 \mathrm{~h} 00$.

Entrevistado: Prof. R. -

Local: DRE Capela de Socorro / Registro: Gravação Eletrônica

Questões:

1- Apresentação pessoal (Formação; Vínculo Institucional;

Experiências, entre outros);

2- Período de sua atuação no cargo atual?

3- Porque você escolheu trabalhar com EJA?

4- O que é a EJA na Capela do Socorro, isto é, como você percebe o seu desenvolvimento?

5- Que experiências você traz desse período de trabalho com EJA?

6- Como se estrutura ou como se apresenta a EJA atualmente perante a Secretaria de Educação?

7- Quais as prioridades educacionais vinculadas à EJA nessa Gestão?

8- $\quad$ Qual foi o projeto mais impactante que você participou nesse percurso com relação à organização dos cursos de EJA? Explique.

9- Que contribuições/ideias/sugestões você proporia para a EJA na cidade de São Paulo e na Capela?

10- E na nossa região Sul, quais as especificidades/peculiaridades que você observou diante de outras regiões da cidade?

11- Do ponto de vista do desenvolvimento da EJA na nossa região Sul da cidade, o que você elencaria como experiências "positivas" e ou "negativas" em todos esses processos que você participou?

12- O que mudou na sua forma de pensamento em EJA depois desse seu tempo coordenando essa pasta?

13- O que você faria novamente e o que você repensaria se tivesse a fazer novamente com relação ao funcionamento de EJA?

14- Como você avalia o esvaziamento das salas de EJA na Capela?

15- Como você avalia a atual organização da EJA na cidade de São Paulo?

16- Quais foram os maiores desafios que você enfrentou nessa tarefa de coordenar os cursos de EJA da Capela? 
APÊNDICE K - Transcrição de Entrevista com Prof. R.

ENTREVISTADA: PROF. RODRIGO

LOCAL: DRE - CAPELA DO SOCORRO

HORÁRIO: 15H 05 MIN EM 19/12/2012.

TEMPO DE DURAÇÃO: $51 \mathrm{~min}$

Autorização concedida na gravação

A atuação Profissional da Prof. $R$.

Desde 2006, designado como Assistente Técnico Educacional na Diretoria de Orientação Técnica e Pedagógica - atuando na Educação de Jovens e Adultos - EJA - das unidades escolares da DRE Capela do Socorro.

Diretor Escolar Efetivo na Prefeitura do Município de São Paulo

Atua, concomitantemente, em Instituição Privada como coordenador no curso de EJA na Zona Sul da cidade de São Paulo.

Trajetória Profissional do Professor $R^{22}$

O professor R. é graduado desde 1976 em Letras pela Universidade de São Paulo - USP. Mestre em Educação pela Pontifícia Universidade Católica de São Paulo - PUC-SP, desde 2004. Antes da sua graduação já trabalhava com a Educação Não Formal de Adultos (suplência), um trabalho de base promovido pela Igreja Católica.

No início de sua carreira, atuou como professor do ciclo II - Língua Portuguesa na Rede Estadual Paulista e em escolas particulares. No período, também atuou cerca de dez anos na Prefeitura de São Paulo como professor do antigo ginásio ( $5^{a}$ a $8^{a}$ séries), até o início dos anos 90. Deixou a Prefeitura na época para assumir um trabalho no Estado

${ }^{22}$ A entrevista com o professor R. foi realizada no dia 19 de dezembro de 2012, às 15 h00min. O professor autorizou a gravação de seu depoimento. 
como Assistente de Direção. Pouco tempo depois, através de concurso público, efetivou-se como Diretor Escolar numa escola da Zona Sul da cidade, próxima ao Autódromo de Interlagos, onde ficou por quase dez anos. Após esse período foi para a Supervisão Escolar Estadual, onde ficou até 2005, quando do seu reingresso na Prefeitura de São Paulo como Diretor efetivo (concursado) numa escola de Ensino Infantil.

Também atuou nestes últimos anos, após a conclusão do mestrado, como professor no Ensino Superior em uma Universidade Privada, nos cursos de Pedagogia e Administração.

- Qual é a sua formação inicial?

Formação inicial de professor do ciclo II e Ensino Médio, especialista na área de Língua Portuguesa. Fiz Letras na Universidade de São Paulo. Sempre trabalhei mais, basicamente, com quinta a oitava série. No campo de trabalho eu privilegiava a quinta série. Sempre gostei de trabalhar com pré-adolescente, embora já tivesse trabalhado com adultos antes de me formar, na educação não formal de caráter supletivo, mas ligado a um trabalho de base da Igreja Católica.

Assim que me formei fui para a Instituição Particular e Instituição Pública, Estado. Acho que depois de dois ou três anos iniciado a docência, fui para a Prefeitura aqui na cidade de São Paulo. Fiquei lecionando uns dez anos. Depois fui formar uma equipe administrativa para trabalhar na gestão escolar como vice-diretor de escola, numa escola pública estadual.

Paulatinamente, fui deixando a sala de aula e fazendo apenas o trabalho administrativo, mas acho que isso durou, talvez, uns dois ou três anos, porque logo em seguida eu retornei para a sala de aula numa escola particular. Levei daí para frente, sempre paralelamente, o trabalho como diretor de escola e professor de rede pública, sempre atuando no que hoje a gente chama de ciclo II. Atuei muito pouco no ensino médio, a minha experiência ainda está muito ligada àquela fase em que a criança não tem ainda toda a aquisição da linguagem, tem ainda questões muito sérias 
como parágrafos, letras maiúsculas, letras minúsculas pra resolver. E por uma questão até de vínculo afetivo eu sempre gostei de trabalhar mais com essa faixa etária, quinta série e sexta série, dos dez anos e onze anos. Fiquei, acho, que uns dez anos assim depois fui pra supervisão escolar e me afastei de novo da docência. Fiquei uns cinco anos só trabalhando na supervisão, depois eu voltei de novo pra docência mas na docência do curso superior, porque nesse período eu fui fazer mestrado e acabei buscando o magistério superior, em curso de pedagogia e em curso de administração.

- O seu mestrado foi em que?

$\mathrm{Na}$ verdade eu sempre gostei de trabalhar mais com crianças, mas o meu mestrado foi na área do significado para os alunos ensino médio e as representações que eles faziam a respeito da escola, então, acabei direcionando para o adolescente na verdade, na faixa etária de ensino médio. Eu não me lembro agora, exatamente, o nome da minha dissertação, mas era mais ou menos assim: as representações e expectativas que eles tinham ao terminar o ensino médio. Que representações eles tinham da escola e o que eles esperavam ao terminar o ensino médio? Fazer o quê com o ensino médio?

Foi na Pontifícia Universidade Católica de São Paulo

- Qual o período de sua atuação no cargo atual e porque você escolheu trabalhar com EJA?

Eu fiquei na verdade de 1987 até anos 90 (na prefeitura). Saí da prefeitura fiquei só no Estado e em 2005 voltei para a prefeitura como diretor de escola efetivo. Fiquei um ano na escola de educação infantil e aí fui convidado para trabalhar aqui em DOT P e estou aqui desde 2006, então, o meu vínculo institucional é um vínculo concursado de diretor de escola e afastado aqui em DOT $P$ com trabalho de formação de professores. Não escolhi trabalhar com EJA, na verdade foi um segmento, um setor de trabalho que me encarregaram de cuidar. 
- Porque você escolheu trabalhar com EJA? Você acabou respondendo (na questão anterior), mas tem alguma especificidade que você gostaria de registrar, deixar claro?

Não. Na verdade eu quando vim pra cá, vim com uma expectativa de trabalhar com formação de professores, independentemente, se ele fosse de EJA ou se fosse de educação fundamental, enfim, mas quando me pediram pra acompanhar a EJA eu acabei recebendo isso como uma alegria até porque eu já tinha dado aula em curso de EJA. Tanto lá num curso informal como eu falei, antes na igreja, como no Estadual tive uma experiência de um ou dois anos com suplência de adultos. Uma experiência que gostei muito, então, eu achei que seria legal fazer esse acompanhamento, conversar com professores, com coordenadores e ver como se dá esse movimento da EJA. Para mim era uma coisa nova porque o funcionamento da EJA na prefeitura ele tinha uma característica diferente, um pouco diferente da EJA do Estado. Porque o Estado trabalhava muito com EJA do ensino médio e a prefeitura trabalhava basicamente com EJA do ensino fundamental.

- Como você percebe o desenvolvimento de EJA na Capela do Socorro, como é que ele tem acontecido?

Acho que houve um momento quando eu cheguei, em 2006/2007, um movimento bastante grande de pensar a EJA, fazer alguma, uma reflexão sobre a EJA e pensar num curso que atendesse os alunos dentro das suas especificidades. Não só do ponto de vista da escolaridade, do tempo que ele ficou sem estudar ou do nível sócio econômico, de onde mora, mas principalmente do ponto de vista da sua condição de trabalhador que o afasta, muitas vezes, da escola que dificulta ele chegar nos horários institucionais de formação,que faz com que ele se canse mais facilmente, que na última aula já não esteja com tanta disposição quanto na primeira. Então pensou-se muito, por exemplo, na questão da flexibilidade ou flexibilização de como atender esse aluno de modo que ele não se 
evadisse e que ele tivesse um tempo de dedicação para a escola, mas que ele tivesse também outro tempo dentro da própria escola de se dedicar a outras questões como a da pesquisa, então, nesse ano de 2007 acho que houve um movimento bastante grande por parte de SME que refletiu aqui na Capela também de se pensar a EJA, se pensar numa estrutura de EJA que pudesse atender os alunos, principalmente nessa questão de fixar 0 aluno na escola.

- E a gente sabe que em 2008 tem a reorganização de EJA. Essa reorganização vai sendo pensada em dois mil e sete?

Vai ser pensada em 2007 e em 2008 é que vem a proposta de implantação

- Deste período de implementação e reorganização de EJA, que experiências você traz hoje?

Para mim, especificamente, foi muito interessante porque foi o momento que eu pude visitar escola, conversar com coordenadores pedagógicos, conversar com professores, conversar com alunos e fazer algumas reflexões a respeito dessa nova estrutura que se estava implantando. Foi bom porque a gente começou a ter uma proximidade com os alunos e com professores que, de qualquer forma provocou um espaço de reflexão. A EJA precisa mudar e nós temos essa proposta, então vamos ver o que essa proposta traz de interessante e como que ela pode ser aplicada e como que ela pode ser de fato implementada. Então para mim, especialmente, foram os momentos de discussão, de reflexão que eu fiz tanto na escola como nesses segmentos todos, inclusive com alguns diretores naquele momento tanto aqui na própria diretoria em DOT $\mathrm{P}$ quanto nas reuniões mensais com os coordenadores pedagógicos e que a gente ia colocando os problemas ou as condições em que isso estava acontecendo lá na escola. 
- Você fala que teve algumas conversas com pessoas no sentido de ouvilas. Tiveram (os professores) uma formação específica para essa modificação em EJA?

Não digo exatamente uma formação, mas alguns momentos aqui na DRE, principalmente com coordenador pedagógico, mas em alguns momentos também com presença de professores. Cada coordenador pedagógico, naquele momento a gente pensou, deve trazer um professor da escola para participar dessas discussões para falar dessa proposta, como isso, do que ela fundamentava. Na verdade do que ela propunha, como ela se estruturaria. Então houve alguns encontros, não muitos, mas houve alguns encontros anteriormente aqui também. Depois, no próprio 2008, um acompanhamento, alguns, também não digo numa ocorrência assim constante e periódica, mas aconteceu algumas vezes com presença do supervisor também aqui em DRE. Nas visitas que fazíamos às escolas também íamos acompanhados do supervisor.

- Como que se estrutura ou como se apresenta a EJA atualmente perante a Secretaria da Educação?

Na verdade aquela proposta de reorganização que aconteceu em 2008 ela não se manteve. Ela acabou ficando na verdade só em 2008 e não teve muito sucesso porque num primeiro momento a Secretaria DOT EJA trabalhou as questões de organização de horário, de grade curricular, e isso acabou encontrando um dificultador na implementação dessa proposta. Acabou encontrando um dificultador na jornada do professor, porque como estava estruturada ela colocava a primeira e a última aula como aula de orientação de estudos e as três aulas do meio como aula presencial, efetivamente. Você tinha um currículo que era chamado currículo, não é central, não me lembro agora, mas é a parte central do currículo e uma parte diversificada que entraria, por exemplo, nessa aula de orientação de estudos que a gente chamou na época de "OEs" que era a primeira e a última (aulas) e aí onde o professor poderia organizar a 
escola, poderia organizar compensações de ausências aulas, de atendimento individual, aula de reforço projeto pesquisa etc. E as três aulas do meio, efetivamente, com as aulas regulares com horário dentro da grade horária. Quando aconteceu a atribuição de aula já com a EJA nessa estrutura, os professores só puderam escolher para compor jornada, as aulas do núcleo central. Então isso diminuiu a possibilidade do professor compor a sua jornada num mesmo período, ele teve que pegar $X$ aulas a noite e $X$ aulas num outro período para completar, e aí, as OEs acabaram ficando para um segundo momento e acabou sendo muito pulverizada, porque quando os professores foram escolher essas OEs, os professores efetivos por exemplo ou os que já tinham passado pelo processo de atribuição, já tinham composto a sua jornada, inclusive com aulas em outro período, então, com isso trouxe um problema seríssimo para composição de horário adequação de um professor num determinado período. E aí acabou tendo algum movimento que eu não posso afirmar com certeza, por que aí eu não participei, mas certamente acabou havendo uma reação da rede e a reestruturação acabou em parte sendo suspensa por uma resolução do secretário que trouxe de volta o funcionamento em termos de cinco aulas no núcleo central. A escola organizada em cinco aulas, tirava-se as OEs., mantinha-se aquela questão de núcleo central diversificada mais aí o núcleo diversificado teria que ser feito em pré-aula, em projetos de outro horário que para o aluno do noturno isso ficava um pouco impensável, até para o professor. Que professor que vem antes do horário, se não tá na sua jornada fazer um horário fazer um trabalho com projeto? Ninguém, penso (...) mesmo o aluno. Então voltou-se as cinco aulas, mas manteve-se por exemplo, o espírito, pelo menos em Lei, dessa visão de núcleo central, núcleo diversificado, mas na verdade o que aconteceu é que houve uma volta ao funcionamento anterior, que prevaleceu até 2011. A única diferença do que ficou da reestruturação? Antes na Prefeitura o supletivo funcionava assim: primeiro termo que durava um ano, segundo, terceiro e quarto do ciclo I que duravam um semestre e depois os outros quatro períodos do 
ciclo II que duravam também um semestre cada um. O que a resolução trouxe? Ela agrupou cada dois termos em 1 ano que chamou de ETAPA então você tinha Primeira Etapa um ano inteiro sem reprovação ou aprovação no meio do ano, quer dizer, ela durava o ano inteiro e essa etapa foi chamada de alfabetização correspondente ao primeiro e segundo termos anteriores. A Segunda Etapa que era Básica correspondente ao terceiro e quartos termos do ciclo I. Depois vinha a Etapa complementar que corresponderia ao primeiro e segundo termos do ciclo II e a última Etapa que é a Etapa final correspondendo ao terceiro e quarto termo do ciclo II. Então o que ficou? Tirou-se toda aquela questão de OEs., funcionamento normal de cinco aulas noturnas, mas a divisão em Etapas anuais com aquele processo de aprovação ou reprovação no final do ano.

- A próxima pergunta tem a ver com a sequencia dessa questão, de como ficou estruturada da EJA até 2011, você fala. Em 2012 tem alguma alteração estrutural?

Aqui na Capela todas mantiveram essa estrutura, em Etapas anuais, em cinco aulas noturnas, como o ensino tradicional, mas houve uma proposta da Secretaria de Educação de se implantar o EJA modular. Como o EJA modular foi uma proposta por adesão, aqui na nossa região nenhuma escola aderiu, então, todas ficaram mesmo naquela estrutura anterior.

- Então para esse ano de 2012 o módulo EJA foi por adesão e nenhuma escola da DRE fez essa opção em aderir?

Não. Uma única escola. Na verdade algumas escolas queriam, mas como a EJA modular prevê trabalhos com módulos e bimestrais, você precisa fazer uma parceria. Do ciclo I não, porque o professor é o único só ele que vai dividir o seu trabalho em módulos e vai ser sempre ele, mas por exemplo, no ciclo II quando você organiza por módulos se uma sala está tendo um módulo de português a outra sala vai ter um módulo de outra disciplina, então, isso exige sempre um número de classes por pares. Eu não posso por exemplo ter um número ímpar. Eu não posso rodiziar então 
o que que aconteceu? As escolas que tinham intenção de aderir, além de não terem esse número par para fazer a dobradinha ou fazer o rodízio, elas também não tinham um número mínimo de salas que permitissem estruturar. Precisaria de um mínimo de uma turma de quatro ou oito. (...) fazer o módulo assim: Língua Portuguesa e Matemática, História e Geografia, então preciso de número par para fazer essa (...) eu tenho cinco já não dá, as escolas queriam, mas elas não tinham número suficiente de turmas para fazer. Não dá para você, por exemplo, se eu tenho 4 salas do ciclo I duas do ciclo II ou uma do ciclo II, não dá.

- As escolas não conseguem serem redondinhas, elas têm as próprias necessidades?

Isso então um módulo no primeiro momento, mas vai faltar turma pra todas as disciplinas...

- Aí fica tudo meio que em stand by, esperando?

Exatamente aí as escolas que queriam não tinham essa condição. Uma escola que tinha condição aderiu, só que os professores não entenderam direito a proposta, ficaram com medo que isso fosse de novo mexer com a questão da jornada deles como aconteceu no ano anteriormente, então fizeram um movimento e um documento aqui para a gente, dizendo que eles desistiam do módulo.

- Quais as prioridades educacionais vinculadas à EJA nessa gestão?

Olha, na verdade hoje eu acho que a prioridade é em função de todo um trabalho que foi feito na Secretaria no sentido de estar também, a exemplo do ensino fundamental, discutindo as especificidades da EJA. É escrevendo e ditando as orientações curriculares para a EJA considerando o público de Jovens e Adultos e discutindo as diretrizes curriculares de EJA como um todo e de cada disciplina as expectativas, organizando assim as diretrizes curriculares. O currículo por expectativas de aprendizagem, cada área teve o seu caderno de orientação curricular, todas elas têm 
uma expectativa em relação a cada disciplina, então, eu acho que ficou bem para mim nesse tempo todo de EJA foi que SME também se preocupou em estar fazendo a organização de que a EJA também tivesse uma diretriz, a seguir então, a prioridade foi mesmo atender à especificidade da EJA. Você tem que ter uma diretriz curricular que atenda às especificidades da EJA. A questão da flexibilidade para o aluno que se evade, daí que vem a EJA modular que procura atender também um pouco essa possibilidade porque o aluno na EJA modular faz um módulo e desiste por algum motivo, quando ele volta, se passou naquele módulo, não precisa fazer de novo aquele módulo, de alguma forma é uma flexibilidade. Mas de uma maneira geral para todo mundo foi pensar nas diretrizes curriculares e pensar nas expectativas de aprendizagem atendendo as especificidades da EJA.

- Qual foi o projeto mais impactante que você participou nesse percurso com relação à organização dos cursos de EJA? Explique.

Eu não sei se tem um projeto específico viu o Márcio porque eu acho que na verdade o que ficou é que a EJA está sempre sendo discutida, mas parece que ela tá sempre nadando em areia movediça. Então eu acho o que ficou de qualquer projeto ou percurso, vamos falar em percurso, que eu tenha participado é a necessidade muito grande se rever a fundo: Qual é a função da EJA não em só São Paulo mas no Brasil? O que significa enquanto nação, de fato, enfrentar o problema do analfabetismo funcional nesse público que é formado de tanto aquele jovem que acaba sendo expulso do ensino fundamental e ainda com pouca idade quer acelera os estudos, você tem por exemplo, os alunos de dezoito anos, dezessete e as vezes de dezesseis anos querendo fazer EJA, ele tá fora da idade/série mas também não é um aluno com tanta idade e justificaria ele acelerar o estudo.

- Que contribuições/ideias/sugestões você proporia para a EJA na cidade de São Paulo e na Capela do Socorro? 
É isso mesmo, parar e pensar o que que é a EJA? Atende a quem? O que significa você ter/fazer um trabalho de inserção desse público na cultura letrada? E de que tipo/pensar o currículo. O currículo de EJA não pode ser o mesmo da escola regular. Eu trabalho numa escola particular e a gente vem discutindo muito isso. Tem alunos que vão fazer vestibular, que as vezes, estão mais pautados no conteúdo, mas acho que de uma maneira geral você não pode perpetuar uma ideia de que formar é dominar uma série de conteúdos aí tradicionalmente eleitos pela sociedade, porque eu vejo por exemplo, quantos alunos mais velhos sofrem com determinados conteúdos e aí eu fico me perguntando: mas isso vai fazer diferença na vida dele? Da maneira como ele tá, é esse o conteúdo que ele tá aprendendo, um conteúdo específico de matemática ou de biologia ou de química português como/qual é a necessidade de fato para que esse aluno/que proficiências a gente tem que buscar para que dentro da cultura se sinta de fato um participante assim da cultura letrada?

- Dentro de tudo isso que você tá colocando aí, disso tudo que a gente tá falando, você com certeza ouviu falar de EJA de outras partes de São Paulo. Você foi a outras reuniões onde encontrou representantes de outros EJAS de outras regiões, como vocês devem ter discutido desse período, cada um o seu problema na sua região, mas da nossa região que mais de especificidade você pôde observar que você não ache em Pirituba, por exemplo, tem alguma coisa muito diferente da sua área, em Capela que aconteça isso, mas em Pirituba não vai acontecer, tem alguma especificidade aqui na nossa região na EJA diferente das outras EJAS de São Paulo?

Olha de uma maneira geral penso que não. Porque um grande problema que a gente tem em EJA é a questão do aluno trabalhador, aquele aluno que tá cansado e que ficou sem estudar um tempão. A volta para ele já é muito pesada porque ele começa entrar num mundo escolarizado, de onde 
ele ficou afastado muito tempo e aí quando tem propostas muito diferentes daquilo que ele pensa que seja escola ele se assusta um pouco, porque o que ele quer mesmo é aprender a escrever e no imaginário dele escola é lousa, lápis, escrever, resolver exercícios, enfim, quando você faz algumas propostas num primeiro momento ele se assusta, embora depois tem um trabalho de convencimento (...) costuma se perceber como agente cultural, produtor da cultura e aí isso acaba sendo mais leve mais fácil, mas tem uma série de coisas. O aluno de EJA volta para a escola com uma série de expectativas, mas ele já tem toda uma vida estruturada e a escola não ocupa uma centralidade para ele. Tem uma expectativa muito grande com relação à escola, mas a centralidade é o trabalho é a subsistência então, por exemplo, no primeiro empecilho se ele não tiver condição de que as expectativas que ele tem estão sendo supridas/idealizadas/contempladas ele desiste. Eu percebo isso tanto aqui quanto, por exemplo, sou coordenador de um curso de EJA numa escola particular com o mesmo público, a escola tem todos os recursos, lá não existe dispensa de aula por motivo nenhum. O aluno vai sabendo que vai ter aula da primeira à última aula.

- Tem professor bem formado professor que atende bem as expectativas dele? Você percebe que ocorre a mesma questão?

Sim, tem professor formado. A mesma questão, por exemplo, se a mãezinha ficou doente vai parar de estudar porque vai precisar cuidar da mãe, porque é diferente, o aluno não é como do regular que se a mãe fica doente quem vai cuidar, enfim, a criança... o adulto não, porque se a mãe já tem 60, 70 anos mora numa outra cidade, ele tranca a matrícula viaja pra cuidar da mãe. Cuidou da mãe, se a mãe sarou ou a mãe morreu volta e volta a estudar. Então é engraçada essa coisa... Eles gostam da escola, eles querem escola, mas não é a centralidade no sentido de que ele precise da escola para organizar a sua vida. A vida dele já tá de alguma forma organizada, isso eu percebo na rede pública, na rede estadual e a gente conversa com outros/outras regiões e se percebe a 
mesma coisa, a desistência, a evasão... Talvez, o que tenha de diferença seja nas regiões centrais, tem alguma diferença, talvez chame um público que já tenha a sua vida financeira ou de trabalho mais organizada, não dependa tanto de trabalhos em subempregos etc., mas de uma maneira geral o adulto que procura a EJA, principalmente nas regiões periféricas, é aquele adulto que tá sem emprego ou tá subempregado ou está desempregado hoje. Arranjou um emprego numa outra cidade ele vai com certeza e não se preocupa muito, assim: "ah... eu vou pegar a minha transferência eu vou levar que vou estudar lá" Não! Ele vai organizar primeiro a vida de trabalho dele lá se der para estudar ele vai estudar se não der ele pára de estudar nesse tempo e quando ele volta, ele procura de novo a vaga.

- Como você avalia o esvaziamento das salas de EJA na Capela?

Eu tenho comparado porque estou na região sul na escola particular e aparentemente os motivos são os mesmos, o trabalho, é o cansaço... Agora tem um motivo que começa aparecer que é velado, eles não falam que é a dificuldade que eles tem de aprender e acho que isso tem a ver com o currículo. Esse conhecimento formal. Você percebe alunos que lidam com matemática no cotidiano muito bem, quando vão formalizar a matemática é um horror, eles não aprendem. Alguns ficam com medo, acham que não vão aprender e acabam desistindo. Só que isso aparece sempre como uma fraqueza, uma vulnerabilidade do educando, nunca do educador que precisa procurar uma outra forma desse aluno chegar ao conhecimento formal. Isso tá muito claro pra mim, eu percebo isso tanto na rede pública aqui, quanto lá no papel de coordenador nessa escola particular e acho que é uma coisa que a gente tem que estar pensando principalmente esse aluno que lida no seu dia-a-dia com números, que lida com espaço geográfico, que lida com o sujeito histórico e aí quando ele vai pra escola é outra representação. E essa dificuldade o afasta e ele prefere assumir uma suposta responsabilidade dele de não saber, 
competência /incompetência, do que questionar o sistema. Então eu acho que é uma questão que a gente precisa atacar.

- Do ponto de vista do desenvolvimento da EJA na zona Sul da cidade, o que você elencaria como experiências "positivas" e "negativas" nos processos em que você participou? O que você considera que seja importante mudar na política administrativa e/ou permanecer se novamente fosse responsável pelo funcionamento de EJA, em 2013?

Olha, eu acho que de positivo foi todo esse movimento no sentido de repensar a EJA. Tem grupos que estão interessados em discutir a EJA. De negativo, a EJA precisa muito de políticas públicas claras. Para mim existe um pouco de descompasso entre algumas propostas que são/ou algumas preocupações que são colocadas por $\mathrm{SME}$, mas não tem ressonância nas regiões, então, SME sempre coloca assim: que o/a questão das matrículas é uma questão de demanda. Tem demanda, tem que ter um/uma escola para atender aquela demanda, mas os setores técnicos não entendem muito bem aí. O que a gente tem visto é uma evasão muito grande e uma redução de salas muito grande e infelizmente, no meu ponto de vista, quando existe uma luta dos docentes para que essas matrículas aconteçam, não é tanto pela preocupação política que representa você ter pessoas alfabetizadas e que isso representa para o país, eu acho que isso é mais no sentido de uma garantia de jornada e acúmulo corporativo/corporativismo, eu acho isso extremamente negativo, se tem que ter é porque tem que ter demanda.

- Você falou uma coisa interessante que eu ainda não havia pensado. Essa é uma pergunta que eu estou retornando. Se você tivesse a oportunidade de modificar algumas questões das políticas públicas pra EJA, parte administrativa? Você falou agora: "olha gostaria que pensasse a EJA conforme a região" (...) quando você fala em setorizar esse atendimento de EJA é disso que você está falando? 
É eu falo. Porque também acho se você tem escolas próximas e aí você tem uma escola - a gente tem que pensar na questão custo benefício também, concorda? - então não pode manter duas escolas funcionando para dar uma sala ou duas salas, para a questão de fixação do professor, acomodação de horário, até da própria convivência dos alunos que, por exemplo, chegam juntos à escola eles vão embora juntos essa convivência é importante porque é segurança. Tem aluno que não vai embora sozinho, espera ali o outro pra ir embora, então uma turma maior é mais positivo você organizar a turma em questão de horário de ter professores para aquelas salas, as próprias atividades do aluno, enfim, mas eu acho que precisa um estudo, um levantamento de demanda onde tenha maior demanda para poder agrupar, contemplar todos os setores, se você tem, como na região de Capela, que a gente vive três grandes setores: Cidade Dutra Grajaú e Parelheiros. Mas Parelheiros começa alí na estrada da Varginha vai até Vargem Grande... Marsilac... Então eu não posso ter um núcleo pra atender o próprio Parelheiros, eu vou dividir em dois ou três sub-regiões. Tem a região da Varginha um pouco mais para frente. Tem a outra região, mais para frente ainda que é Marsilac, Vargem Grande etc. Deveria se pensar em termos de onde está essa demanda. Tem a questão do custo benefício, não haja dúvida, mas também tem a questão do atendimento dessa demanda que tem de compatibilizar de alguma forma essa necessidade.

- A necessidade que essas pessoas tem de estudarem, a questão da responsabilidade de manutenção desses locais que vão ser justamente essa questão. Você trouxe uma coisa interessante aqui nessa questão que seria a 13. Sobre a evasão, como você avalia o esvaziamento das salas de EJA na Capela como nós falamos, então já vi que você percebeu alguns motivos aí algumas hipóteses que levariam a esse esvaziamento, entre elas, todo esse arcabouço de dificuldades que vimos até agora. Na evasão pelo que eu percebi temos a questão, a pergunta que eu queria é 
a seguinte: Você acredita que nós tenhamos demanda e ela está, por algum motivo, reprimida?

- SIM

Está reprimida por fatores que extrapolam a nossa instância enquanto instituição seria isso? Essa é a questão que eu gostaria de perguntar, quer dizer, Tem evasão? A questão é, todos se formaram então, não existe mais adulto pra se formar? Mudaram de cidade? Ou por vários motivos acabam?

Não. São Paulo tem um número grande de pessoas (sem formação) daí que eu falo para você quanto à política pública que partisse de uma força tarefa do Estado das instâncias governamentais que se pensasse de fato. Eu penso que enquanto a gente pensar em EJA com base na estrutura curricular do ensino regular ela vai ter (quebra pensamento) o atendimento a essa demanda... flexibilidade... as questões sazonais... o trabalho. O trabalho ocupa uma centralidade é lógico. Tenho filhos para sustentar, estou estudando, estou desempregado se eu arrumar emprego numa outra cidade eu vou deixar o meu estudo, então, como atender esse aluno também? Se há um projeto de atendimento para este adulto que não pôde estudar na idade certa eu não posso simplesmente trazê-lo, inseri-lo no sistema e ele puxar um percurso que foi interrompido lá traz da mesma maneira. Pensar também a questão da própria formação do professor, que a grande maioria dos professores tem uma formação única e acaba dando aula na EJA da mesma forma que ele dá aula no regular como para o fundamental... crianças para os jovens.

- Quais foram os maiores desafios que você enfrentou para coordenar os cursos de EJA da Capela?

Não digo para coordenar, o que eu penso, primeiro essa questão que tá lá na escola, a questão do corporativismo. Acho que é muito grande. Tento manter a todo o custo salas de EJA a noite porque pra atender o acúmulo de algumas pessoas, o acúmulo é legítimo não vou discutir isso, mas ele 
acaba sendo corporativista. Então primeiro penso nisso, depois pensar o curso. Se o curso existe, primeiro tem que pensar num curso que vai atender uma demanda e que tem características específicas e que se não tiver eu tenho que manter a todo o custo porque eu preciso de demanda. Você tem um esvaziamento que acontece muito. Começa com salas de 40 terminam com 15... Tem alguma coisa aí que precisa ser repensada, tem que ser avaliada, mas atendeu um propósito primeiro que foi manter a aula para atender aos acúmulos, mas tem uma outra questão que é a própria presença do aluno ali. Porque se esse aluno não chegou até o fim? A escola não tá atendendo. Uma questão que eu acho complicada e não falei lá traz, o aproveitamento desse aluno. A gente percebe o aluno com grande dificuldade de escrita e de leitura terminando 0 ensino fundamental. Minimamente, esse aluno que passa pela EJA, a gente tem que ter como umas das questões claras, ele ter domínio de algumas habilidades. Uma delas é a leitura e escrita. Para mim é mais importante que o domínio de determinado conteúdos disciplinares, é saber lidar com a leitura, escrita e interpretação, quer dizer, ele ter rudimentos para poder acessar os bens culturais e não é dominando conceitos dessa ou daquela disciplina que ele vai... (não completou) Se ele pegar um texto ler e não conseguir entender o que ele tá lendo, dentro desse nível, acho que a escola tá falhando. Acho que é/uma questão bastante grande... o desafio é pensar um curso que realmente atenda a flexibilidade, mas fugir do molde tradicional: tenho que ter cinco horas, tenho que ter aquela carga horária, tem que ter a mesma grade disciplinar... Eu acho que isso tem que ser repensado... Se já não tá funcionando muito no ensino regular imagina para o aluno da EJA.

Está ótimo Rodrigo. As maiorias das coisas acho que a gente acabou privilegiando, não na sequencia, porque a gente vai e volta, acho que nós privilegiamos tudo assim. Tirei coisa aqui que eu não tinha pensado ainda (...). Queria agradecer aqui a sua entrevista a sua participação. Devo fazer uma transcrição da nossa conversa, devo te enviar por e-mail depois 
te envio e se você quiser rever, olha isso... Você manda o aval dizendo é isso mesmo ok e aí transcrevendo e fazendo um resumo e estar trabalhando com a sua entrevista. Mais uma vez, foi um prazer. Acabou agora às 15h55min. 


\section{ANEXOS}

ANEXO A - Cópia de Gráfico divulgado por SME, em apostila, como justificativa por ocasião da Reestruturação dos cursos de EJA no ano de 2008.

\section{INTRODUCÃ̃O}

Tem-se verificado na cidade de Salo. Paulo, em piocesso semelhante ao que ocorre nacionalmente, uma queda constante de matriculas na Educáçào de Joven e Adultos no Ensino Fundamental e Módio, como demonstram as séries históricas de matriculas entre 1997 e 2007:

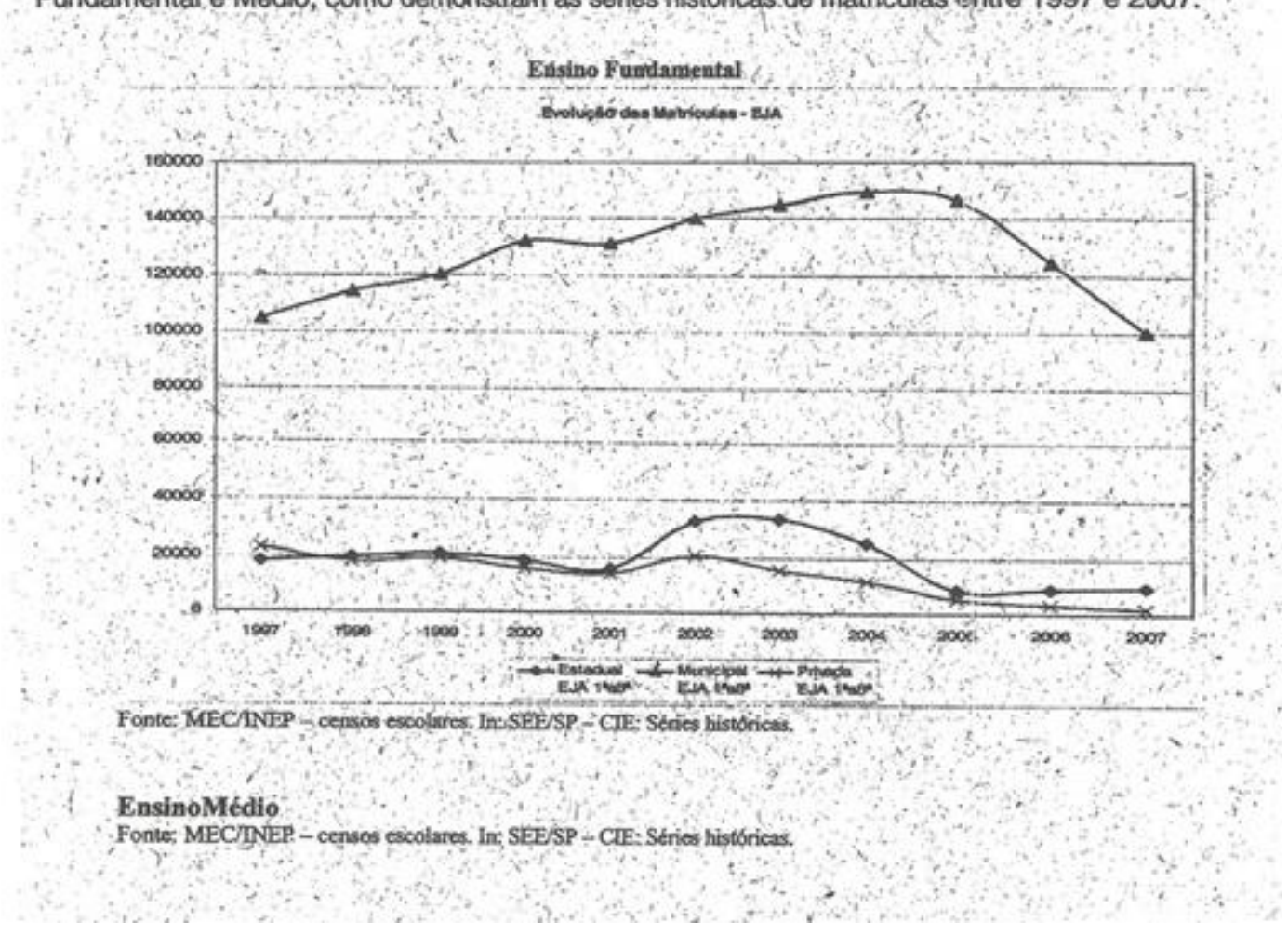




\section{ANEXO B - Cópia do Protocolo de Projeto - Anel Viário do Complexo}

Jurubatuba, São Paulo, Capital.
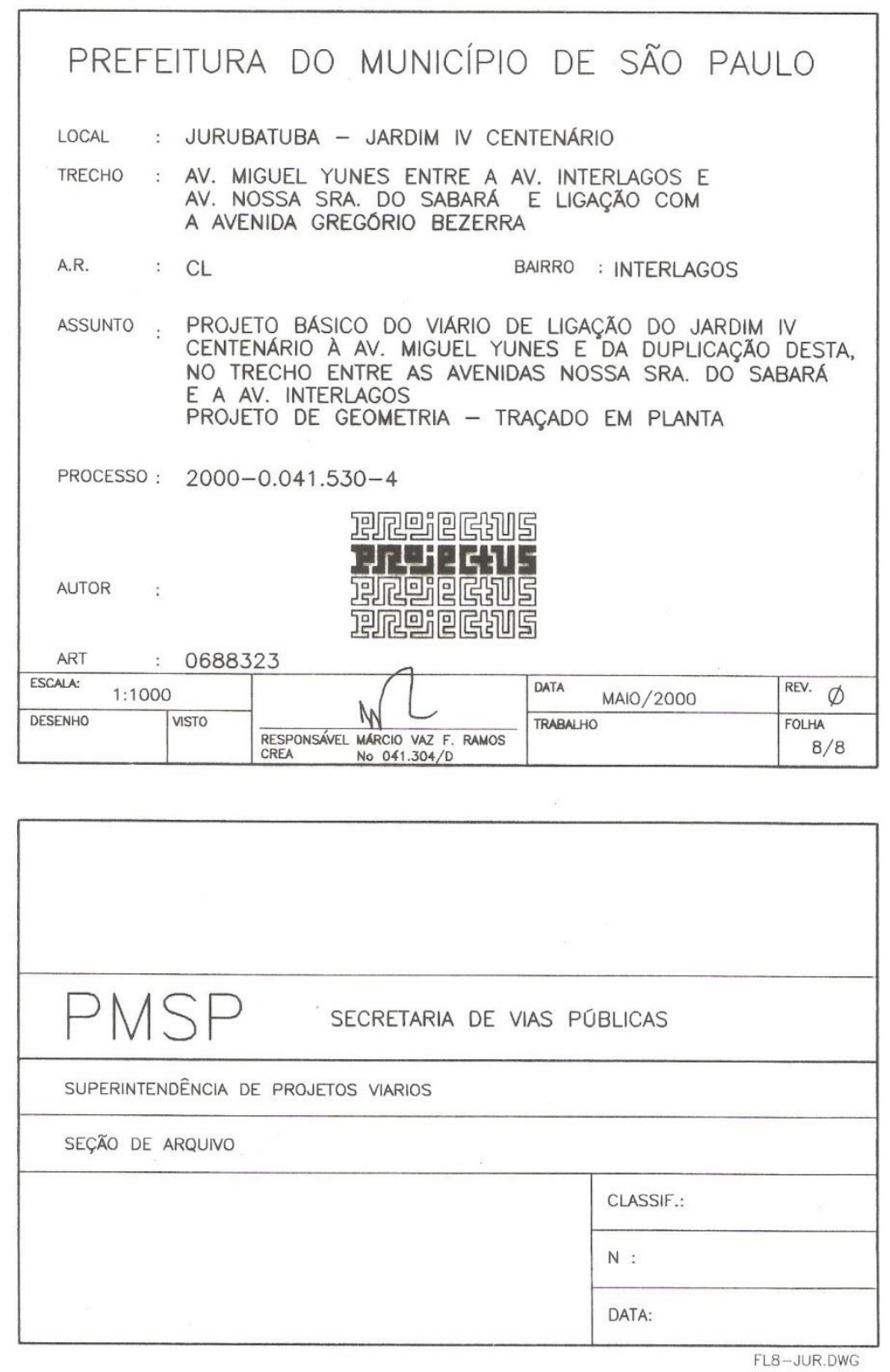
Autorizo a reprodução e divulgação total ou parcial deste trabalho, por qualquer meio convencional ou eletrônico, para fins de estudo e pesquisa, desde que citada a fonte.

Catalogação na Publicação

Serviço de Biblioteca e Documentação

Faculdade de Filosofia, Letras e Ciências Humanas da Universidade de São Paulo

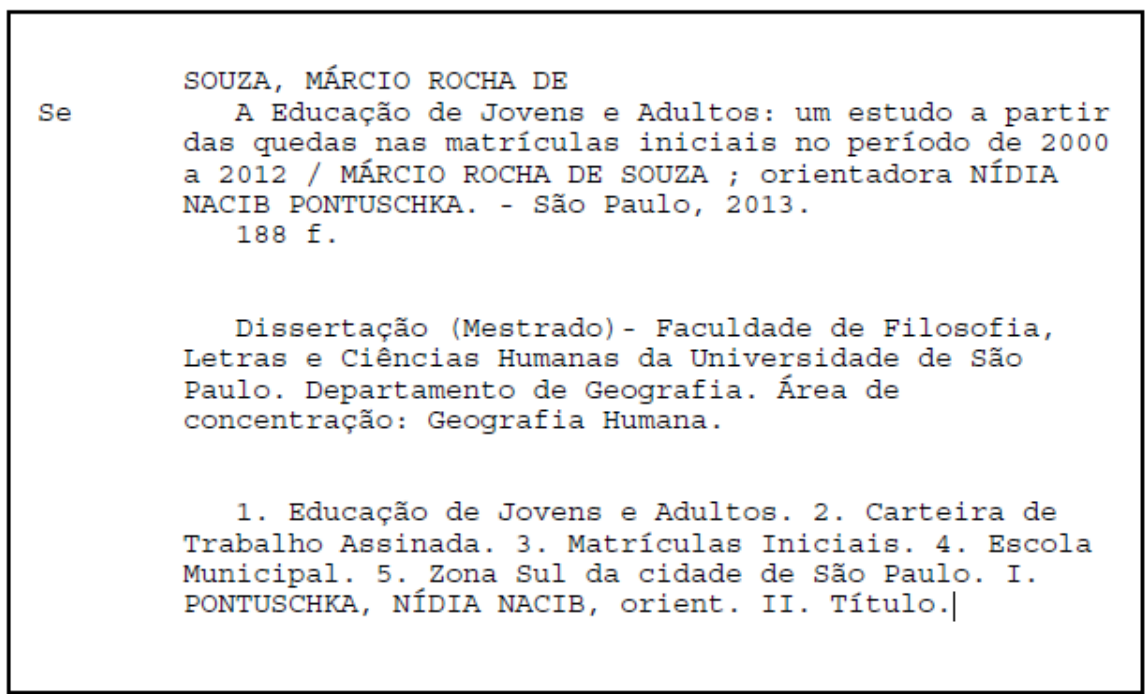

